$$
\text { Universidade de São Paulo - USP }
$$

Faculdade de Filosofia, Letras e Ciências Humanas - FFLCH Programa de Pós-Graduação em Sociologia - Mestrado

\title{
BALANÇO DA PRODUÇÃO ACADÊMICA BRASILEIRA SOBRE CONDIÇÕES E RELAÇÕES DE TRABALHO DOS TERCEIRIZADOS
}

\section{ADRIANA M. MARCOLINO}

São Paulo, SP - Julho de 2019 


$$
\text { Universidade de São Paulo - USP }
$$

Faculdade de Filosofia, Letras e Ciências Humanas - FFLCH

Programa de Pós-Graduação em Sociologia - Mestrado

\section{BALANÇO DA PRODUÇÃO ACADÊMICA BRASILEIRA SOBRE CONDIÇÕES E RELAÇÕES DE TRABALHO DOS TERCEIRIZADOS}

ADRIANA M. MARCOLINO

Dissertação de Mestrado
apresentada ao Programa de
Pós-graduação em Sociologia
da Faculdade de Filosofia,
Letras e Ciência Humanas da
Universidade de São Paulo.

Orientação da Prof. Dra. Paula Regina Pereira Marcelino

Versão corrigida.

São Paulo, SP - Julho de 2019 
Autorizo a reprodução e divulgação total ou parcial deste trabalho, por qualquer meio convencional ou eletrônico, para fins de estudo e pesquisa, desde que citada a fonte.

Marcolino, Adriana M.

Balanço da produção acadêmica brasileira sobre condições e relações de trabalho dos terceirizado / Adriana M. Marcolino; orientador Paula Regina Pereira Marcelino. - São Paulo, 2019. $242 \mathrm{f}$.

Dissertação (Mestrado) - Faculdade de Filosofia, Letras e Ciências Humanas da Universidade de São Paulo. Departamento de Sociologia. Área de concentração: Sociologia.

1. Precarização do trabalho. 2. Terceirização. 3. Sociologia do trabalho. 4. Relações de trabalho. 5. Condições de Trabalho. I. Marcelino, Paula Regina Pereira, orient. II. Título. 


\title{
BALANÇO DA PRODUÇÃO ACADÊMICA BRASILEIRA SOBRE CONDIÇÕES E RELAÇÕES DE TRABALHO DOS TERCEIRIZADOS
}

\author{
ADRIANA M. MARCOLINO
}

Essa dissertação foi julgada e aprovada em:

29 de agosto de 2019

\section{BANCA EXAMINADORA}

Paula Regina Pereira Marcelino - FFLCH - USP - Presidente

Gustavo Venturi Junior - FFLCH - USP

Maria da Graça Druck de Faria - UFBA - Externo

Thiago Trindade de Aguiar - Externo 
"Adentramos os lares desses trabalhadores aos finais de semana, encontramos semblantes cansados aparentando mais idade do que realmente têm; fomos recebidas com certa desconfiança, 0 medo de perder o emprego "paira no ar". Houve momentos em que os entrevistados concordaram em falar estabelecendo como condição o não registro das falas no gravador; em outros momentos fomos recebidos por respondentes que, como num grito de socorro, pedem que suas vozes, seus desconfortos sejam ouvidos. Fica registrada a pergunta de uma delas: essa tua pesquisa, vai ajudar a gente em alguma coisa?"

Caleffi, Vilma Marta, "Reestruturação produtiva na indústria do vestuário e as implicações para qualificação dos trabalhadores", p. 23. Grifos meus. 


\section{AGRADECIMENTOS}

A construção do conhecimento é coletiva, feita a muitas mãos, mesmo em uma pesquisa como essa, assinada por uma única pessoa. A construção coletiva também é possível pela conjunção de vários apoios. Essa sessão de agradecimentos tem essa finalidade: destacar todos aqueles que contribuíram para a produção desse conhecimento, ou que apoiaram esse processo, das mais diversas formas.

Nesse sentido, de reconhecer que todo conhecimento é construído coletivamente, uma primeira referência é aos autores de todas as teses e dissertações que acumularam dados, informações e reflexões sem as quais, esse estudo síntese não seria possível. Espero dar voz de forma fiel às pesquisas que vocês realizaram.

Eu já tentei trilhar esse caminho em outro momento da minha vida, mas foi agora, com o encontro de tantas pessoas especiais, que me apoiaram e colaboraram de diversas formas, que cheguei ao final desse trajeto.

O primeiro agradecimento é para as duas entidades sindicais para as quais exerço, cotidianamente, a profissão de socióloga. À CUT (Central Única dos Trabalhadores) por liberar as horas de estudo necessárias para que eu pudesse cursar as disciplinas do mestrado e para que eu pudesse realizar a pesquisa e escrever a dissertação, a agradecimento especial ao Sérgio Nobre. Ao DIEESE que também apoiou essa liberação para os estudos. As duas entidades também foram (e são) fundamentais em todas as reflexões que realizo sobre as relações de trabalho, suas transformações e os impactos para os trabalhadores, as trabalhadoras e suas representações sindicais. Contribuem cotidianamente para a construção desse conhecimento coletivo.

Agradeço imensamente aos colegas de trabalho da assessoria da CUT, aos dirigentes sindicais e aos meus colegas do DIEESE, que ouviram lamentos, reflexões e questionamentos sobre os temas aqui presentes. $\mathrm{Na}$ CUT, agradecimento especial a Elaine, que me ajudou a refletir sobre o tema de saúde do trabalhador, para que eu não caísse em nenhum deslize. No DIEESE, meu agradecimento especial para David, Leandro e Patrícia, 
companheiros de trabalho e amigos, que me apoiaram, cobriram minhas faltas, ouviram minhas preocupações e incentivaram essa jornada.

A minha "professora" e revisora, Fátima, também sou muito grata. Fátima está listada entre as quatro pessoas fundamentais na minha formação, assim que iniciei minha atividade profissional, logo depois de formada em ciências sociais - generosa, mas também rigorosa em todos os trabalhos que realizamos juntas. Aprendi a construir um questionário, a realizar uma entrevista, a ser fiel no uso das informações colhidas no campo. Obrigada por me ensinar e por ler com carinho e atenção esse longo texto, colocando as vírgulas no lugar, os verbos no tempo certo, indicando os problemas de entendimento e a consistências dos argumentos!

Meus colegas do grupo de estudo Sindicalismo e política brasileira, da Pós em Sociologia, FFLCH/USP: gostaria de agradecer por acompanharem essa trajetória, debatendo comigo desde o projeto de pesquisa até o texto final da dissertação, mesmo nas férias.

Um agradecimento especial para a minha orientadora, Paula Marcelino. Obrigada pelo apoio, pela empatia, pela orientação. Obrigada por entender meus limites, como mãe, trabalhadora e estudante, e claro, por me orientar de forma tão cuidadosa ao longo de todo o processo no mestrado. Que bom encontrar uma mulher, professora universitária, como uma visão crítica do mundo e da universidade!

Minha família não poderia ficar de fora. Minhas irmãs e meu irmão que de uma forma ou de outra me ajudaram, principalmente a Suzana, por algumas dicas preciosas sobre metodologias que eu poderia utilizar. Obrigada também a minha irmã de vida, Suzana Lourenço, que deu aquela geral no abstract! Gratidão às vovós Juracy, Clarice e Maria, que formam minha rede de apoio solidário para o cuidado de duas crianças sapecas. Gratidão também à Zelma que, com seu trabalho cotidiano de cuidados, torna minha jornada de trabalho diária menor, deixo registrado que reconheço meus privilégios de ter esse apoio.

Ao meu companheiro de vida, de luta política e de estudos, Sérgio, essa jornada só foi possível, em sua maior parte, porque você estava do meu lado. 
Obrigada por aturar as centenas de lamentações nesses trinta meses, por ler meus textos, criticá-los e ainda ter paciência com a minha resistência às mudanças sugeridas por você, aliás, sempre pertinentes. Obrigada por me manter calma e focada, na medida do possível. Obrigada por assumir todas as tarefas da casa nesses últimos meses, prometo que agora voltaremos a compartilhá-las!

E para terminar, meu agradecimento mais que especial às duas meninas que fazem parte de mim, que compõem quem eu sou, Lulu e Juju. Obrigada por sentarem do meu lado e estudarem junto comigo. Juju, eu espero que você tenha entendido os textos da mamãe que você pegou pra ler e que tenha entendido as faltas da mamãe nos passeios, nas brincadeiras... A maior parte da sua vidinha até agora, você me acompanhou nessa trajetória NE? Lulu, obrigada por me explicar, por escrito, o que é uma vírgula (Eu, moro, em, uma, casa.) quando eu estava com dificuldade de consertar a pontuação! E Lulu, todas aquelas leituras no campo da medicina para entender o que estava acontecendo com você, me aproximaram de metodologias que utilizo aqui na pesquisa. Meninas, obrigada por sempre me darem um beijo de boa noite, de bom dia, de boa tarde, seguido de um "bom estudo!". Vocês sempre recomendaram para que eu fizesse a lição de casa direitinho, espero que eu tenha conseguido. 


\section{RESUMO}

Diversos autores destacam a terceirização como um dos principais dispositivos utilizados para a superação da crise do Ford ismo e para o estabelecimento de um novo padrão de acumulação nas últimas décadas do século XX. Há uma vasta produção acadêmica que analisa as condições e relações de trabalho dos terceirizados e demonstra que seu objetivo é reduzir os gastos com força de trabalho, através de sua precarização. Essas pesquisas empíricas possuem uma riqueza de detalhes do levantamento in loco de como se dá o processo, mas por se tratar Estudos de caso apresentam uma análise fragmentada, geográfica ou setorialmente. Utilizamos esses estudos para a realização de um balanço da produção acadêmica sobre terceirização, através de um estudo síntese das teses e dissertações sobre condições e relações de trabalho que nos possibilitou elaborar um painel nacional sobre esse fenômeno. Através desse estudo procuramos responder às seguintes questões: qual o alcance regional e setorial do processo de terceirização como um dos principais componentes da precarização do trabalho no Brasil? Quais são as formas de mais recorrentes de trabalho precário nos processos de terceirização? É possível afirmar que os processos de terceirização, se bem aplicados como sugerem alguns manuais de administração empresarial, não resultem em precarização do trabalho? Nossa hipótese é de que os processos de terceirização têm a tendência à precarização, mas é possível encontrar graus variados a depender do lugar na cadeia de fornecimento (de insumos ou de serviços) que a empresa terceira ocupa e do nível de organização dos trabalhadores. Esses diferentes graus são utilizados para justificar que pode existir uma "boa aplicação" e uma "má aplicação" da terceirização. Para realizar nossa pesquisa utilizamos duas bases documentais: 1) as fichas catalográficas das teses e dissertações, que foram sistematizadas através de uma análise bibliométrica, com o objetivo de mapear a produção acadêmica e que colaboraram para a seleção dos documentos que tratassem das condições e relações de trabalho dos terceirizados; 2) análise de conteúdo das teses e dissertações selecionadas, através da Revisão Bibliográfica Sistemática (RBS), que nos auxiliou na sistematização de evidência e na construção dos indicadores de precarização da terceirização.

Palavras chave: relações de trabalho, condições de trabalho, terceirização, precarização do trabalho; sociologia do trabalho. 


\begin{abstract}
Several authors highlight outsourcing as one of the main devices used to overcome the crisis of Faradism and to establish a new standard of accumulation in the last decades of the twentieth century. There is a vast academic production that analyzes the conditions and labor relations of the outsourced workers, which demonstrates that the purpose of this device is to reduce labor costs through the precariousness of work. These researches case studies and empirical - have a wealth of details of the on-site survey about how the process and its effects occur. Nevertheless, they are limited due to the fragmentation of the analysis. We verified the academic production on outsourcing by selecting theses and dissertations about conditions and labor relations. Then, we systematized and analyzed the information available in these documents on the impacts of outsourcing process for the working class. Considering several sectors of economic activity and regions of the country, we answer the follow questions: what is the scope of the outsourcing process as one of the main components of the precariousness of work in Brazil? What are the most recurrent forms of precarious work used in outsourcing processes? Is it possible to affirm that the outsourcing processes, if well applied as suggested by some business administration manuals, do not result in precarious works? Our hypothesis is that outsourcing tends to be precarious, but it is possible to find varying degrees of precariousness, depending on the place in the supply chain (inputs or services) that the outsourced company occupies and the level of mobilization of the workers, and that these different grades are used to justify that there may be "good application" and "misapplication" of outsourcing. To carry out our research we use two documentary bases: 1. the catalogs of the theses and dissertations, which were systematized by bibliométrica analysis, in order to map the academic production and to find out information that both enabled a first analysis on the subject and collaborated for the selection of the documents to deal about the conditions and relations of outsourced workers; 2. the content of selected theses and dissertations, analyzed by Systematic Bibliographic Review (SBR), which also helped us in the systematization of evidences and to construct indicators of precarious outsourcing.
\end{abstract}

Keywords: work relationships; work conditions; outsourcing; work precarious; labour sociology. 


\section{SUMÁRIO}

LISTA DE SIGLAS E ABREVIATURAS

INTRODUÇÃO

1. OS PROCESSOS DE TERCEIRIZAÇÃO EM UM CENÁRIO DE

ACUMULAÇÃO FLEXÍVEL E PRECARIZAÇÃO DO TRABALHO

1.1. AS DISPUTAS PELA REGULAÇÃO DA TERCEIRIZAÇÃO NO BRASIL

1.2. ESPECIALIZAÇÃO PRODUTIVA VERSUS PRECARIZAÇÃO DO TRABALHO - OS INTERESSES DE CLASSE ENVOLVIDOS NA DISPUTA EM TORNO DA TERCEIRIZAÇÃO NO BRASIL

2. MAPEAMENTO DA PRODUÇÃO ACADÊMICA SOBRE O TEMA DA TERCEIRIZAÇÃO NO BRASIL - 1995 A 2016

2.1. OS AVANÇOS E LIMITES DOS ESTUDOS QUANTITATIVOS SOBRE A TERCEIRIZAÇÃO

2.2. CONSTRUINDO O UNIVERSO DE PESQUISA: OS ESTUDOS DE CASO SOBRE A TERCEIRIZAÇÃO

2.3. METODOLOGIA UTILIZADA PARA SELEÇÃO DOS DOCUMENTOS

2.4. PERFIL DOS ESTUDOS SOBRE CONDIÇÕES E RELAÇÕES DE TRABALHO DOS TERCEIRIZADOS NO BRASIL

2.5. DIMENSÕES E TEMAS PARA A CONSTRUÇÃO DOS INDICADORES DE PRECARIZAÇÃO DAS CONDIÇÕES E RELAÇÕES DE TRABALHO

3. IMPACTOS DA TERCEIRIZAÇÃO PARA AS RELAÇÕES DE TRABALHO 80

3.1. A COLETA DAS TESES E DISSERTAÇÕES COMPLETAS 80

3.2. A REVISÃO BIBLIOGRÁFICA SISTEMÁTICA

3.3. ANÁLISE DAS RELAÇÕES DE TRABALHO DOS TERCEIRIZADOS NO BRASIL 


\subsection{TERCEIRIZAÇÃO E A HIERARQUIA DA PRECARIZAÇÃO - UM RECORTE} SETORIAL

4. CONSIDERAÇÕES FINAIS

- Uma agenda de pesquisa sobre terceirização

5. REFERÊNCIAS BIBLIOGRÁFICAS

5.1. Referências bibliográficas - Teses e dissertações utilização na Revisão Bibliográfica Sistemática

6. ANEXOS

ANEXO I - Documentos que não foram encontrados para a classificação do balanço da produção acadêmica brasileira sobre condições e relações de trabalho dos terceirizados - Análise Bibliométrica

ANEXO II - Sistematização das Teses e dissertações sobre Terceirização disponíveis na Capes/Grande Área de Conhecimento Ciências Humanas

ANEXO III - Lista de teses e dissertação completas que não foram encontradas para Revisão Bibliográfica Sistemática (RBS)

ANEXO IV - Teses e dissertações completas que foram excluídas da RBS, após leitura sistemática 


\section{LISTA DE SIGLAS E ABREVIATURAS}

ABC Cidades que compõe a região de Santo André, São Bernardo e São Caetano.

ACT Acordo Coletivo de Trabalho.

BDTD Biblioteca Digital Brasileira de Teses e Dissertações.

CAGED Cadastro Geral de Empregados e Desempregados.

CAPES Coordenação de Aperfeiçoamento de Pessoal de Nível Superior.

CBO Classificação Brasileira de Atividade.

CC Código Civil.

CCJC Comissão de Constituição e Justiça da Câmara dos Deputados.

CCT Contrato Coletivo de Trabalho.

CF Comissão de Fábrica.

CGTB Central Geral dos trabalhadores do Brasil.

CLT Consolidação das Leis do Trabalho.

CNAE Classificação Nacional de Atividade Econômica.

CNC Confederação Nacional do Comércio.

CNI Confederação Nacional da Indústria.

COMUT Serviço de Comutação Bibliográfica.

CREAS Centro de Referência Especializado de Assistência Social.

CTB Central dos Trabalhadores e das Trabalhadoras do Brasil.

CTPS Carteira de Trabalho e Previdência Social.

CUT Central Única dos Trabalhadores.

CTPS Carteira de Trabalho e Previdência Social.

DIAP Departamento Intersindical de Assessoria Parlamentar.

DIEESE Departamento Intersindical de Estatísticas e Estudos 
Socioeconômicos.

FE/USP Faculdade de Educação da Universidade de São Paulo.

FFLCH/USP Faculdade de Filosofia Letras e Ciências Humanas da Universidade de São Paulo.

FGTS Fundo de Garantia por Tempo de Serviço.

IP/USP Instituto de Psicologia da Universidade de São Paulo.

MBB/SBC Mercedes Bens de São Bernardo do Campo, SP.

MEC Ministério da Educação.

MSC Mensagem Presidencial.

MTE Ministério do Trabalho e Emprego.

MTPS Ministério do Trabalho e Previdência Social.

NCST Nova Central Sindical dos Trabalhadores.

ND Não Disponível.

NSA Não Se Aplica.

OIT Organização Internacional do Trabalho.

PED Pesquisa de Emprego e Desemprego.

PJ Pessoa Jurídica.

PL Projeto de Lei.

PLC Projeto de Lei Complementar.

PLR Participação nos Lucros e Resultados.

PLS Projeto de Lei do Senado.

PNAD Pesquisa Nacional por Amostra de Domicílio.

PT Partido dos Trabalhadores.

PUC Pontifícia Universidade Católica.

PUC/SP Pontifícia Universidade Católica de São Paulo

RAIS Relação Anual de Informações Sociais.

RBS Revisão Bibliográfica Sistemática. 
RJ Cidade do Rio de Janeiro.

SMABC Sindicato dos Metalúrgicos do ABC.

SNPG Sistema Nacional de Pós-Graduação.

SP $\quad$ Cidade de São Paulo.

STF Supremo Tribunal Federal.

TEDE Publicação Eletrônica de Teses e Dissertações.

TST Tribunal Superior do Trabalho.

UGT União Geral dos Trabalhadores.

USP Universidade de São Paulo. 


\section{LISTA DE TABELAS, QUADROS E FIGURAS}

QUADRO 1 - Projetos de Lei em tramitação no Congresso Nacional, 2016

QUADRO 2 - Perguntas disponíveis nas principais bases estatísticas sobre o mercado de trabalho no Brasil

FIGURA 1 - Ilustração da tela de acesso ao Catálogo de teses e dissertações da Capes e Plataforma sucupira, 2018

TABELA 1 - Local de coleta dos resumos das teses e dissertações analisadas

QUADRO 3 - Campos utilizados para a construção do mapeamento da produção acadêmica sobre condições e relações de trabalho entre os terceirizados

GRÁFICO 1 - Número de teses e dissertações sobre condições e relações de trabalho dos terceirizados por ano, 1995-2016, Brasil

TABELA 2 - Distribuição dos autores e autoras das Teses e Dissertações sobre condições e relações de trabalho dos terceirizados por sexo, 1995 a 2016, Brasil

TABELA 3 - Distribuição das Teses e Dissertações sobre condições e relações de trabalho dos terceirizados por área-programa de pós-graduação, 1995 a 2016, Brasil

TABELA 4 - Distribuição das Teses e Dissertações sobre condições e relações de trabalho dos terceirizados por universidade, 1995 a 2016, Brasil

TABELA 5 - Distribuição das Teses e Dissertações sobre condições e relações de trabalho dos terceirizados por objeto investigado, 1995 a 2016, Brasil

TABELA 6 - Distribuição das Teses e Dissertações sobre condições e relações de trabalho dos terceirizados por setores de atividade econômica, 1995 a 2016, Brasil

QUADRO 4 - Empresas objeto de estudo das Teses e Dissertações sobre condições e relações de trabalho dos terceirizados selecionadas, 1995 a 2016, 75 Brasil

TABELA 7- Temas presentes nas teses e dissertações sobre condições e relações de trabalho dos terceirizados, 1995-2016, Brasil (Múltipla resposta)

FIGURA 2 - Etapas da pesquisa

QUADRO 5 - Eixos e códigos para elaboração da Revisão Bibliográfica Sistemática

QUADRO 6 - Códigos e evidências da precarização das condições de trabalho dos terceirizados

GRÁFICO 2 - Indicadores de precarização das condições de trabalho nas 
teses e dissertações sobre terceirização, Brasil, 1995 a 2016 (\%)

TABELA 8 - Frequência dos indicadores de precarização do trabalho do eixo condições de trabalho, presentes nas teses e dissertações sobre terceirização, Brasil, 1995 a 2016

QUADRO 7 - Códigos e evidências das condições precárias nos Contratos Individuais de Trabalho

GRÁFICO 3 - Indicadores de precarização dos contratos individuais de trabalho nas teses e dissertações sobre terceirização, Brasil, 1995 a 2016 (\%)

TABELA 9 - Frequência dos indicadores de precarização do trabalho do eixo Contratos Individuais de Trabalho, presentes nas teses e dissertações sobre terceirização, Brasil, 1995 a 2016

QUADRO 8 - Códigos e evidências das condições precárias para a saúde do trabalhador terceirizado

GRÁFICO 4 - Indicadores de precarização das condições de saúde do trabalhador das teses e dissertações sobre terceirização, Brasil, 1995 a 2016 $(\%)$ 


\section{INTRODUÇÃO}

Diversos autores destacam a terceirização como um dos principais dispositivos utilizados como estratégia de superação da crise do Fordismo e para o estabelecimento de um novo padrão de acumulação nas últimas décadas do século XX.

Os estudos demonstram que a terceirização:

(...) modificou de forma estrutural o conjunto da base produtiva e de serviços no país (...) criaram formatos de empresa e tipos de contrato de trabalho de natureza distinta daqueles que vigoravam na tradicional empresa fordista do século XX (...) alterou estruturalmente 0 mercado de trabalho, empresas e trabalhadores passaram a se relacionar em condições econômicas, políticas e sociais significativamente distintas. (MARCELINO; CAVALCANTE, 2012, p. 332).

Há ainda uma vasta produção que analisa as condições e relações de trabalho dos terceirizados e demonstram quais as diferentes formas de utilização desse mecanismo pelas empresas para reduzir os gastos com a força de trabalho através de sua precarização. Esses estudos apontam a tendência à precarização das condições de trabalho e a ampliação das dificuldades enfrentadas pelas entidades sindicais para a organização coletiva dos trabalhadores, consolidando na prática uma terceirização muito distante daquela apresentada nos manuais de administração ou direito. Os manuais definem esse processo como estratégico para a focalização de atividades (concentrar as atividades da empresa em sua atividade principal), com ganhos de produtividade e qualidade, que se aproximam mais de uma visão idealizada do que um processo real (MARCELINO; CAVALCANTE, 2012; DRUCK, 1999; DIEESE, 2011).

Em 2011, devido à pressão empresarial para que o Tribunal Superior do Trabalho (TST) reformulasse a Súmula 331 para ampliar o alcance da terceirização, foi realizada uma audiência pública com a participação de representantes do governo, empresários e trabalhadores, buscando um fato político que justificasse a alteração nessa legislação. Nessa audiência, foi apresentado o Dossiê "Desenvolvimento e terceirização: uma conta que não fecha" (2011), elaborado pelo Departamento Intersindical de Estatísticas e 
Estudos Socioeconômicos (DIEESE) em parceria com a Central Única dos Trabalhadores (CUT) e outras entidades sindicais. Esse documento apresentava, entre outros dados, uma análise quantitativa da terceirização, buscando identificar sua extensão e efeitos no mercado de trabalho brasileiro, demonstrando que esse processo representava perdas para os trabalhadores. Esse estudo foi uma tentativa de sistematização de dados e informações sobre a terceirização no Brasil, mas também enfatizava os limites das bases de dados estatísticos utilizadas, pois, apesar da relevância da terceirização para as relações de trabalho, as estatísticas de mercado de trabalho disponíveis para sua análise quantitativa eram e continuam sendo parciais e deficientes, tanto sobre o tamanho desse universo quanto sobre as principais características desse fenômeno.

Se por um lado, as estatísticas nacionais poderiam ser modificadas para ampliar sua capacidade de análise sobre o tema, destaca-se também que esse fenômeno é de difícil mensuração, pois é próprio da terceirização tornar encobrir as formas de precarização, os processos e as relações de trabalho e tornar invisível o trabalhador terceirizado. Isso ocorre seja devido à dupla responsabilidade (empresa contratante e terceirizada), seja pelos contratos de trabalho precários, pela dispersão geográfica que ela proporciona, ou ainda, devido à rotatividade, entre outros motivos que iremos expor ao longo dessa pesquisa.

Por outro lado, há uma grande produção acadêmica, em diversas áreas de conhecimento, através principalmente de estudos de caso, que demonstram como esse processo tem ocorrido na prática, buscando analisar quais os efeitos da terceirização sobre o trabalho em diversas localidades, em diversos setores econômicos e seus efeitos distintos para diferentes segmentos de trabalhadores. No entanto, se a riqueza dos estudos de caso é o levantamento in loco de como se dá o processo e seus efeitos, eles têm um limite devido à fragmentação da análise, seja territorial, setorial ou porque estuda uma determinada empresa.

Em outra direção, um grupo de estudos sobre a terceirização procura analisar a terceirização do ponto de vista do negócio, da relação entre as empresas e da complementaridade da produção, ignorando a perspectiva das 
condições e relações de trabalho e recusando uma leitura de que a terceirização é fonte de precarização do trabalho, considerando-a como uma técnica que garante aumento de produtividade e qualidade promovidas pela especialização técnica das empresas e que apenas em situações de erro de sua implantação é que pode ocorrer alguma perda para os trabalhadores.

Considerando esses elementos do debate sobre a terceirização no Brasil, nosso objetivo nessa pesquisa foi de realizar um balanço da produção acadêmica sobre terceirização, analisando as informações disponíveis nas teses e dissertações de 1995 a 2016, que retratassem a implantação desse processo e seus efeitos sobre as condições e relações de trabalho.

Como propõe Marcelino (2008, p. 21):

Uma crítica mais contundente à terceirização é possível quando adotado o ponto de vista da classe trabalhadora, daqueles que vivem esse processo não da óptica dos resultados empresariais, mas das consequências nas relações de trabalho e de emprego, além dos efeitos sobre a sua subjetividade e sua organização de classe.

Por isso, nossa pesquisa de base documental tem como foco os estudos de caso que apresentam como objeto de pesquisa as relações e condições de trabalho, ou que, mesmo possuindo outros objetos de pesquisa, analisem também esses elementos. Os estudos de caso são fonte principal de estudos qualitativos no país sobre processos de trabalho e garantem maior uniformidade e detalhamento na sistematização das informações que iremos coletar.

A definição do termo "relações de trabalho" é amplamente utilizada para descrever todos os aspectos e dimensões que envolvem centralmente a relação entre capital e trabalho, entre empregador e empregado, mas também, a relação do Estado na mediação entre essas classes. Em nossa dissertação utilizamos o termo composto por "condições" e "relações" de trabalho para dar ênfase também às condições de trabalho fortemente afetadas pela terceirização.

A partir da pesquisa, procuramos avaliar: qual o alcance regional e setorial do processo de terceirização como um dos principais componentes da precarização do trabalho no Brasil? Quais são as formas de mais recorrentes 
de trabalho precário nos processos de terceirização? É possível afirmar que os processos de terceirização, se bem aplicados como sugerem alguns manuais de administração empresarial, não resultem em precarização do trabalho?

Nossa hipótese estudada é que os processos de terceirização têm a tendência à precarização, mas com a existência de graus variados a depender do lugar na cadeia de fornecimento que a empresa terceira ocupa e do nível de organização dos trabalhadores, e que esses graus diferentes são utilizados para justificar que pode existir uma "boa aplicação" e uma "má aplicação" da terceirização.

Para realizar nossa pesquisa utilizamos duas bases documentais: 1) as fichas catalográficas das teses e dissertações, que foram sistematizadas em um banco de dados, com o objetivo de mapear a produção acadêmica, com informações que possibilitaram a seleção daquelas que tratam das condições e relações de trabalho dos terceirizados; 2) o texto completo das teses e dissertações selecionadas, que foram utilizadas para a construção do balanço da produção acadêmica, através da elaboração de indicadores de precarização das condições e relações de trabalho dos terceirizados.

Esse levantamento foi realizado através do Catálogo de Teses e Dissertações da Coordenação de Aperfeiçoamento de Pessoal de Nível Superior (Capes), por meio do qual selecionamos as pesquisas considerando dois critérios: busca com o termo "Terceirização" e documentos da "Grande área de conhecimento Ciências Humanas", no período disponível nesse acervo, até o momento da pesquisa, que era de 1995 a 2016. Essa pesquisa resultou em 235 teses e dissertações, das quais 114 tinham como tema as condições e relações de trabalho ${ }^{1}$.

Vale destacar que apesar dos avanços para dar visibilidade à produção acadêmica através de plataformas na web, tanto entre às universidades como para a sociedade em geral, ainda há um longo caminho a ser percorrido. Ainda há lacunas no acesso eletrônico mesmo para teses e dissertações mais recentes.

\footnotetext{
${ }^{1}$ O recorte temporal inicial diz respeito ao ano em que o Banco de Teses e Dissertações da Capes tem inicio, 1995. O corte temporal final foi definido na data em que iniciamos a coleta, em junho de 2017. Nessa data, os documentos cadastrados mais recentes eram os de 2016.
} 
No primeiro capítulo apresentaremos as disputas ocorridas entre trabalhadores e empresários nas últimas décadas, para efetivar uma regulação que limitasse a terceirização, defendida pela maior parte das organizações sindicais, e do outro lado, a defesa de uma regulação que representasse "segurança jurídica" para programar os processos de terceirização de forma irrestrita, representada pelas associações de classe patronais. Essa disputa resultou na aprovação do PL (Projeto de Lei) 13.429/2017 que estabelece a terceirização ampla e sem garantias para os trabalhadores. Nesse capítulo também apresentamos 0 contexto de disseminação do processo de terceirização no Brasil e seus efeitos destacados em diversos estudos e finalmente, apresentamos a definição de terceirização que iremos utilizar ao longo da pesquisa, considerando que ainda há na produção acadêmica, divergências e imprecisões no uso desse termo e nas formas que ele assume.

No segundo capítulo, apresentamos o mapeamento da produção selecionada no Catálogo de Teses e Dissertações da Capes, através de uma análise bibliométrica. Esse capítulo apresenta três resultados: a seleção dos documentos que servirão de base para a análise da presente pesquisa, um mapeamento das 114 pesquisas que têm como tema as condições e relações de trabalho dos terceirizados e, por fim, a definição das principais categorias de análise a serem utilizadas no capítulo seguinte.

No terceiro capítulo, apresentamos a análise de conteúdo dos documentos selecionados, por meio da sistematização das evidências e da construção de indicadores de precarização das condições e relações dos terceirizados no Brasil, a partir dos estudos de caso já realizados no país. Essa análise está divida em quatro eixos: Condições de trabalho, Contrato individual de trabalho; Saúde do trabalhador e Ação coletiva e ação sindical.

Destaca-se, ainda, que elaboramos o capítulo terceiro utilizando a Revisão Bibliográfica Sistemática (RBS). Essa metodologia permite sistematizar e analisar grandes massas de informações qualitativas, com garantia de reprodutibilidade, proporcionada pela ampla produção acadêmica sobre a temática da terceirização disponível eletronicamente. A RBS é um método científico para busca e análise de artigos de um determinado campo de conhecimento, não se trata de um levantamento da literatura existente, mas de 
um estudo síntese que testa uma hipótese (GOMES CAMINHA 2014).

A utilização dessa metodologia inova nos estudos sobre a terceirização no Brasil. Em primeiro lugar, porque possibilita uma análise sobre as características e os efeitos da terceirização no país de forma mais generalizada e abrangente, em segundo, porque sistematiza as ocorrências de precarização mais frequentes de forma qualitativa e também quantitativa. Ainda podemos destacar a importância do estudo síntese como forma de dar maior visibilidade à produção acadêmica em sociologia do trabalho, especificamente no tema da terceirização. Por fim, o estudo síntese permite destacar pontos já bastante consolidados na análise sobre a terceirização e temas que podem ser objeto de novas agendas de pesquisa.

A análise bibliométrica de 245 teses e dissertações e a leitura sistemática de $90^{2}$ desses documentos não deixaram dúvidas sobre o processo de terceirização e seus efeitos, com uma abrangência bastante uniforme nos diversos estudos de caso: precarização do trabalho e da vida dos trabalhadores e trabalhadoras e dificuldades adicionais à organização coletiva e sindical. Mas a terceirização vai além, ela fragmenta sua construção identitária através da criação de distinções, do fomento à discriminação entre trabalhadores diretos e terceirizados e da promoção de disputas entre os trabalhadores, jogando uma cortina de fumaça sob a verdadeira fonte de exploração, o capital.

Nas considerações finais, além da retomada de alguns temas, também apresentamos algumas considerações sobre o campo de pesquisa da sociologia do trabalho em especial, dos estudos sobre a terceirização. A pesquisa aqui realizada, mesmo centrando a análise no conteúdo sobre a terceirização, não pôde deixar de considerar as questões recorrentes nas teses e dissertações sobre metodologia, dimensões de pesquisa, limites e avanços desse campo de conhecimento e agendas de pesquisa em curso ou que poderiam proporcionar importantes desdobramentos para a Sociologia do Trabalho.

Como conclusão os efeitos da terceirização podem ter variações,

\footnotetext{
${ }^{2}$ Dos 114 documentos alvo, conseguimos cópia de 90, conforme detalhado no Capítulo 3.
} 
considerando o setor de atividade econômica a qual pertença à empresa contratante ou o setor de atividade econômica do qual faça parte a empresa terceirizada contratada, ou ainda, do nível de organização dos trabalhadores. A diversidade de casos estudados de forma sistemática possibilitou a construção de um painel nacional sobre as características e os efeitos da terceirização, demonstrando que não há dualidade nesse processo - ao contrário do que afirma o discurso empresarial. O objetivo da terceirização é reduzir o custo do trabalho para o empregador e está relacionado ao processo de valorização do capital nesse momento histórico. Em todas as teses e dissertações foi constatadas uma diversidade de temas relacionados à de precarização do trabalho, como veremos a seguir.

\section{Um breve registro em primeira pessoa}

Minha atividade profissional é estudar as relações de trabalho no Departamento Intersindical de Estatísticas e Estudos Sócio Econômicos, assessorando diretamente o movimento sindical. Cotidianamente estudamos, lemos, analisamos dados e informações sobre esse universo, avaliamos as transformações nas empresas, mas também na regulação pública, e seus efeitos para os trabalhadores e trabalhadoras. No entanto, ler, ao longo de meses, os relatos sobre as condições de trabalho e vida dos trabalhadores e trabalhadoras de diversos locais e setores, o registro de suas falas, de suas aflições, da resignação como enfrentam a situação de precarização do trabalho e privação nas condições de vida, e de uma esperança que vem não se sabe de onde, é uma experiência perturbadora, às vezes até agressiva, e muitas vezes emocionante para qualquer um que defenda um mundo menos desigual. É um retrato fundamental que apenas a pesquisa empírica pode descrever. 


\section{Os processos de terceirização em um cenário de acumulação flexível e precarização do trabalho}

Nesse capítulo, apresentaremos na primeira seção o processo de disputa em torno da regulação da terceirização no Brasil, buscando destacar os conflitos de interesse entre empresários e trabalhadores e suas posições sobre o tema. Na sequência, buscaremos refletir sobre as diferentes definições de terceirização e sua relação com as posições dos empresários e trabalhadores, para apresentar o conceito que utilizaremos ao longo da pesquisa.

\subsection{As disputas pela regulação da terceirização no Brasil}

Nessa seção, apresentaremos alguns elementos em torno das disputas que ocorreram para aprovação da regulamentação da terceirização, considerando principalmente, as últimas duas décadas (a partir de 1998). Esse período é aquele em que se dá a maior expansão da terceirização no país e também é o período em que as teses e dissertações que analisaremos foram elaboradas.

Para esta seção utilizaremos como material de pesquisa os Projetos de Lei, seus substitutivos, o texto final aprovado e o histórico de tramitação na Câmara dos Deputados e no Senado Federal $^{3}$. Também foram utilizadas matérias de jornais e os relatórios de reuniões das Centrais Sindicais ou de espaços de negociação tripartite aos quais tivemos acesso ${ }^{4}$.

3 Todas essas informações são públicas e estão disponíveis em:

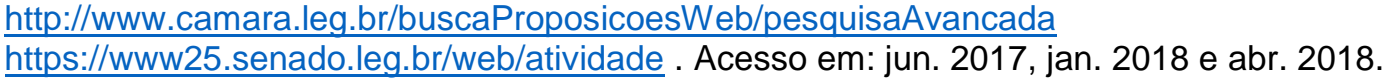

${ }^{4}$ Como técnica do DIEESE, participei como assessora do Grupo de Trabalho sobre Terceirização da CUT (constituído em 2004), do Fórum em Defesa dos trabalhadores ameaçados pela terceirização (constituído em 2011), da mesa de negociação quadripartite sobre o PL 4330/2004 (instalada em 2013) e das negociações em torno da proposta de substitutivo para o PLS 30/2015 (número dado ao PL 4330/2004 quando foi aprovado na Câmara e remetido ao Senado). Para o debate aqui apresentado, utilizamos como referência os materiais públicos (jornais e documentos do Congresso Nacional), em algumas situações utilizamos materiais que tiveram circulação entre as Centrais Sindicais e assessorias (relatórios e propostas de projeto de Lei), mas que não são de acesso restrito e podem ser consultados por outros pesquisadores. 
Considerando a legislação nacional, as primeiras formas de regulação da terceirização podem ser identificadas com a locação de serviços prevista no Código Civil (CC) de 1916, que permitia o trabalho realizado de forma subordinada, mas que foi revogado pela Consolidação das Leis do Trabalho (CLT), em 1943. Na própria CLT também foi incluído um dispositivo que permitia a contratação de trabalhadores através de subempreiteira (Art. $455^{5}$, Decreto 5452/1943), mas com garantia de responsabilidade solidária ${ }^{6}$ da empresa contratante, mesmo em situações de terceirização em cascata/quarteirização (CARELLI, 2007).

Depois desse período, novas legislações foram criadas durante a ditadura militar. O Decreto 200/1967 determinava que as atividades executivas do Estado (a chamada administração indireta) fossem "descentralizadas" através das autarquias, fundações, empresas públicas e sociedades de economia mista. Um dos dispositivos previstos para a descentralização foi à terceirização de serviços considerados acessórios (RAMOS, 2001). Para o setor privado, em 1974 foi aprovada a Lei 6019/1974 que permitia a contratação de trabalhador temporário através de empresa interposta, um novo tipo de contrato de trabalho com direitos reduzidos (OLMO, 2016).

Na década de 1980, nos últimos suspiros da ditadura militar no Brasil, mais um setor é liberado para a terceirização: os serviços de segurança, vigilância e transporte de valores sob o argumento da singularidade do serviço e da necessidade de treinamento específico (Lei oㅜ 7.102/1983). Com essa abertura da terceirização para um serviço "especializado", teve início um movimento de disseminação da terceirização justificado pela suposta

\footnotetext{
5 "Art. 455 - Nos contratos de subempreitada responderá o subempreiteiro pelas obrigações derivadas do contrato de trabalho que celebrar, cabendo, todavia, aos empregados, o direito de reclamação contra o empreiteiro principal pelo inadimplemento daquelas obrigações por parte do primeiro. Parágrafo único - Ao empreiteiro principal fica ressalvada, nos termos da lei civil, ação regressiva contra o subempreiteiro e a retenção de importâncias a este devidas, para a garantia das obrigações previstas neste artigo" CLT, Lei 5.452/1943. Disponível em: <http://www.planalto.gov.br/ccivil_03/decreto-lei/Del5452.htm>. Acesso em: jan. 2018.

${ }^{6}$ Responsabilidade solidária: sempre que uma ou mais empresas, embora tendo, cada uma delas, personalidade jurídica própria, estiverem sob a direção, controle ou administração de outra, constituindo grupo industrial, comercial ou de qualquer outra atividade econômica, serão, para os efeitos da relação de emprego, solidariamente responsáveis a empresa principal e cada uma das subordinadas (Parágrafo $2^{\circ}$ do artigo $2^{\circ}$ da CLT). Disponível em: <https://www.jusbrasil.com.br/topicos/28966956/responsabilidade-solidaria>. Acesso em: 30 jul. 2017.
} 
"especialização" que foi sendo empregado em diversos segmentos nas empresas (RAMOS, 2001).

No início da década de 80 as novas formas de organização produtiva em linha com o novo padrão de acumulação flexível foram se expandindo com grande velocidade nos países centrais e já começaram a reverberar no Brasil. A liberdade para terceirizar serviços acessórios presente no Decreto 200/1967 e o conceito de "especialização" da Lei 7.102/1983, são pontos de apoio para sua difusão desse novo padrão no país, tendo a terceirização como elemento de destaque.

Essa difusão não ocorreu sem a contestação dos sindicatos de trabalhadores. Como forma de resolver as disputas entre sindicatos e empresas e regulamentar supostas lacunas, o TST promulgou a Súmula 256 em 1986. Nesse documento o Tribunal reafirmava que a terceirização estava liberada apenas para os contratos de trabalho temporários e de vigilância e que os demais casos seriam considerados ilícitos e seria redefinido o vínculo empregatício com a empresa contratante (RAMOS, 2001).

A forma encontrada pelas empresas para burlar os limites definidos pela Súmula 256/1986 foi reforçar a caracterização da terceirização como prestação de serviços, utilizando o Capítulo VIII - Da Empreitada ${ }^{7}$, previsto no Código Civil, destacando a prestação de serviços especializados e técnicos. Esse movimento patronal foi vitorioso e deu origem a novas pressões que levaram o TST a editar uma nova Súmula, a 331 de 1993 (RAMOS, 2001).

No entanto, novamente, a regulamentação que deveria estabelecer limites acabou permitindo a ampliação dos processos de terceirização. A Súmula 331/1993 permite a terceirização desde que não atinja as atividadesfim da empresa e de que não haja subordinação direta dos trabalhadores à empresa tomadora dos serviços terceirizados. A Súmula também prevê a figura da responsabilidade subsidiária ${ }^{8}$ da empresa contratante dos serviços, ao invés

\footnotetext{
${ }^{7}$ Disponível em: <http://www.planalto.gov.br/ccivil 03/Leis/2002/110406.htm>. Acesso em: 20 jan.2018.

${ }^{8}$ A responsabilidade subsidiária prevê que se a prestadora de serviços não efetuar 0 pagamento dos créditos salariais devidos ao trabalhador, à responsabilidade por esse pagamento deve ser transferida à empresa contratante, no entanto, isso ocorre apenas via judicial. Com a responsabilidade solidária a empresa contratante é diretamente responsável
} 
de reforçar o dispositivo da responsabilidade solidária, já existente em algumas legislações como a empreitada e os contratos temporários (SOUTO MAIOR, 2016).

Mesmo esses pontos que representavam limites para a expansão da terceirização, foram frequentemente desrespeitados pelas empresas e serviram de motivação para diversos processos movidos pelos sindicatos de trabalhadores, que na maior parte das vezes, seguiu o caminho lento dos processos judiciais. O conteúdo dessas limitações também foi pouco concreto: atividade-fim e atividade-meio são conceitos pouco precisos e mesmo a responsabilidade subsidiária acaba ocorrendo apenas via medida judicial (MARCELINO; CAVALCANTE, 2012). A Súmula 331 também proíbe a intermediação da mão de obra, à exceção da Lei 6019/1974, mas também define que a contratação irregular de trabalhadores através de empresa interposta não caracteriza vínculo se isso ocorrer na administração pública. Por fim, ainda promove a ampliação da terceirização para os setores de conservação, limpeza e todas as atividades meio das empresas contratantes (DRUCK, 2007).

Outro problema são as omissões: apesar de pautada pelo conceito da "especialização da produção", a Súmula 331 não vinculou a legalidade do processo de subcontratação ao critério de especialização de serviços empresariais. Sem essa obrigação, surgiram empresas de prestação de serviços sem uma finalidade econômica específica que se caracterizavam pela simples interposição da força de trabalho, rompendo com os pressupostos do direito do trabalho e de proteção ao trabalhador (SOUTO MAIOR, 2016).

A partir de 1998, com o PL 4302, o debate sobre uma regulamentação mais abrangente para a terceirização ganha espaço. Até então, as regras procuravam regular situações específicas, apesar de paulatinamente ampliar as possibilidades de terceirização, como vimos nos parágrafos acima.

Nos últimos vinte anos, diversos projetos de Lei foram apresentados no Congresso Nacional, buscando regulamentar o processo de terceirização.

pelas verbas não pagas. Tribunal Superior do Trabalho. Disponível em: $<$ http://tst.jusbrasil.com.br/noticias/2760890/sumula-331-preve-responsabilidade-subsidiariaem-relacao-a-todas-as-verbas>. Acesso em: 30 jul. 2017. 
Esses projetos podem ser divididos em dois grupos. De um lado, aqueles que propunham uma regulamentação que estabelecesse segurança jurídica para as empresas contratantes, liberando os processos de terceirização do trabalho em todas as atividades econômicas, sem limites quanto aos setores internos das empresas que poderiam ser terceirizados, e sem responsabilidade solidária, o que é defendido pelos empresários (DIAP, 2016). Entidades patronais como a Confederação Nacional do Comércio (CNC) defenderam ao longo desse processo que a terceirização colaborava com a ampliação da especialização, adicionando qualidade e inovação tecnológica aos produtos e serviços, resultando em aumento da produtividade, da competitividade e de empregos, além de significar a modernização das relações entre firmas (CNC, 2017a; CNC, 2017b).

Em documentos da Confederação Nacional da Indústria (CNI) é possível encontrar a terceirização como pauta prioritária. Como exemplo, o documento Mapa estratégico 2013-2022: propostas para a eleição 2014 - Terceirização, o imperativo das mudanças (2014) destacava os prejuízos da falta de um marco legal para regulamentar a terceirização. Segundo o documento, as relações de trabalho eram regidas por uma Lei criada na década de 1940, que sequer cogitava as mudanças que ocorreram na estrutura produtiva ao longo do tempo e estaria "(...) longe da realidade atual de um mundo interconectado, com cadeias de produção horizontalizadas" (CNI, 2014a, p.11).

Outro documento da CNI que podemos citar é a Agenda legislativa anual da indústria ${ }^{9}$. Nesse documento, apresentam-se os principais pontos de interesse da entidade patronal e sua posição, para ser entregue aos deputados e senadores federais. No ano de 2014 foi elaborada uma edição mais concentrada chamada "Pauta Mínima, edição de bolso" com apenas 14 pontos, no qual figurava o apoio ao PL 4330/2004 (CNI, 2014b).

Em outra direção, pode-se observar uma série de projetos que propunha a regulamentação da terceirização com mecanismos para impedir a precarização do trabalho, com limites sobre quais áreas dentro de uma

\footnotetext{
${ }^{9}$ No site é possível consultar as edições dessa publicação da CNI desde 2006 até 2018. Disponível em: <http://www.portaldaindustria.com.br/publicacoes/2015/12/agenda-legislativada-industria/\#agenda-legislativa-da-industria-2018\%20>. Acesso em: mai. 2018.
} 
empresa poderiam ocorrer à terceirização, o que é defendido, pelo menos, pelas centrais sindicais reconhecidas pelos critérios do Ministério do Trabalho. Nesses projetos o entendimento era da terceirização como instrumento para redução de custo com a retirada de direitos dos trabalhadores e como elemento que fragilizava a organização sindical (DIAP, 2016).

A CUT elaborou em conjunto com o Deputado Vicentinho (Vicente de Paula, PT/SP), ex-presidente da Central, o PL 1621/2007. Segundo a CUT, a inexistência de uma legislação que regulamentasse a terceirização contribuiu para sua expansão nas esferas pública e privada e nos diferentes setores de atividade (DIEESE/CUT, 2011). Com esse projeto, o objetivo era proibir a terceirização na atividade fim e garantir a isonomia de salários, da jornada de trabalho, de benefícios, além de boas condições de saúde e segurança. O PL também previa que a empresa prestadora deveria ter finalidade específica para coibir interposição de mão de obra e que a empresa contratante deveria ser solidariamente responsável com possíveis débitos trabalhistas e previdenciários (PL 1621/2007).

Depois da apresentação desse projeto, a Força Sindical, a Central dos Trabalhadores e Trabalhadoras do Brasil (CTB), a Central Geral dos Trabalhadores do Brasil (CGTB), a União Geral dos Trabalhadores (UGT) e a Nova Central Sindical dos Trabalhadores (NCST) se somaram a essa estratégia legislativa e elaboraram em conjunto uma nova proposta no ano de 2009 (DIAP, 2013).

Esse novo texto possui alguns pontos distintos dos previstos no PL 1621/2007, na busca de contemplar as demais centrais sindicais. Entre as diferenças, a minuta de PL elaborada pelas centrais sindicais propunha regular o contrato de prestação de serviços, enquanto o PL 1621/2007 tratava das relações de trabalho dos terceirizados. Outra diferença é que a minuta de PL das centrais não incluía as empresas de economia mista. O PL 1621/2007 apresenta proibição expressa ao uso de Pessoa Jurídica (PJ) ou empresa de intermediação de mão de obra, além das já previstas na Lei; enquanto a proposta de minuta de PL das centrais apresentava apenas uma referência ao 
Artigo $3^{\circ}$ da $\mathrm{CLT}^{10}$. O PL 1621/2007 definia que não poderia haver distinções salariais, de jornada, entre outras, enquanto o PL das centrais previa a garantia para os terceirizados dos direitos previstos na convenção coletiva da categoria da empresa contratante (CENTRAIS SINDICAIS, 2009).

Por fim, o PL 1627/2007 previa a constituição de uma comissão com representantes dos trabalhadores das prestadoras de serviço e dos respectivos sindicatos enquanto a minuta de $\mathrm{PL}$ das centrais não fazia menção a dispositivos organizativos dos trabalhadores terceirizados (CENTRAIS SINDICAIS, 2009).

Essa minuta de PL foi debatida com os Ministros do Trabalho e de Assuntos Estratégicos e foi entregue ao então presidente, Luiz Inácio Lula da Silva ${ }^{11}$. A proposta era que a minuta fosse apresentada na Câmara dos Deputados como um PL do Poder Executivo, o que facilitaria a tramitação e a possibilidade de apensar ${ }^{12}$ os PL 4302/1998 e 4330/2004, que ficariam subordinados ao projeto elaborado pelas centrais sindicais. No entanto, o PL nunca foi apresentado para a Câmara dos Deputados (LOUREIRO, 2009).

No quadro 1 (página 22) é possível observar as principais proposições sobre a Terceirização. A primeira delas, como dito acima, foi o PL 4302/1998. Inicialmente esse PL tratava do trabalho temporário, mas durante a tramitação foram incluídos artigos que buscavam a liberação irrestrita da terceirização, incluindo medidas que permitissem a terceirização da atividade fim da empresa, sem a contrapartida da responsabilidade solidária, sem critérios de

\footnotetext{
${ }^{10}$ Art. $3^{\circ}$ - Considera-se empregado toda pessoa física que prestar serviços de natureza não eventual a empregador, sob a dependência deste e mediante salário. Parágrafo único - Não haverá distinções relativas à espécie de emprego e à condição de trabalhador, nem entre 0 trabalho intelectual, técnico e manual. Disponível em: <>. Acesso em: 20 abr.2018.

${ }^{11}$ Houve uma tentativa de negociação em uma mesa tripartite, mas as confederações patronais se retiraram do processo. Disponível em: $<$ http://www.diap.org.br/index.php/noticias/noticias/22827-centrais-lancam-nota-sobreterceirizacao-regular-sem-precarizar>. Acesso em 20 abr. 2018.

${ }^{12}$ Apensar (Tramitação em conjunto): propostas semelhantes são apensadas ao projeto mais antigo. Se um dos projetos semelhantes já tiver sido aprovado pelo Senado, este encabeça a lista, tendo prioridade sobre os da Câmara. Se for o Poder Executivo, o também recebe prioridade na tramitação. O relator dá um parecer único, mas precisa se pronunciar sobre todos. Quando aprova mais de um projeto apensado, o relator faz um substitutivo ao projeto original. O relator pode também recomendar a aprovação de um projeto apensado e a rejeição dos demais. Disponível em: <http://www2.camara.leg.br/camaranoticias/noticias/69896.html>. Acesso em: 24 abr. 2018.
} 
isonomia das condições de trabalho e sem critérios sobre representação sindical.

O PL 4302/1998 tramitou mesmo depois da Mensagem Presidencial (MSC 389/2003) solicitando seu arquivamento, resultado de acordo entre o então Presidente Lula e as Centrais Sindicais. Como o PL havia sido apresentado pelo Presidente Fernando Henrique Cardoso, somente o próprio Poder Executivo poderia pedir seu arquivamento (DIAP, 2008). A Mensagem Presidencial nunca foi apreciada, mesmo com a pressão das centrais sindicais e das várias tentativas das bancadas de esquerda que conseguiram incluí-la na mesa diretiva da Câmara dos Deputados nos anos de 2003, 2004, 2007 e em $2017^{13}$, poucos dias antes da aprovação do PL 4302/1998.

Apesar de não ser arquivado, devido à forte pressão política em 2008, o PL 4302/1998 teve sua tramitação paralisada e as atenções se voltaram para 0 PL 4330/2004, que se tornou o novo foco da pressão política dos setores empresariais que buscavam uma regulamentação irrestrita da terceirização.

Em 2013, diante das tentativas de aprovação do PL 4330/2016 na Comissão de Constituição e Justiça da Câmara dos Deputados (CCJC), as centrais sindicais organizaram uma grande onda de manifestações. Ocorreram pelo menos 5 atos nacionais (3/julho/2013; 18/julho/2013; 06/08/2013; 13/08/2012; 4/09/2013), além de mobilizações frequentes contra a tramitação do projeto, ocupação do Congresso Nacional, e audiências públicas no Congresso Nacional e nas Assembleias estaduais ${ }^{14}$.

Frente a essa reação do movimento sindical, foi criada uma mesa quadripartite com a participação do Poder Executivo, Câmara dos Deputados, confederações patronais e centrais sindicais de trabalhadores. Essa mesa tinha como objetivo debater e elaborar uma proposta de consenso entre empresários e trabalhadores, considerando os seguintes pontos: abrangência da terceirização (limites para atividade-fim, quarteirização e pejotização), responsabilidade solidária versus subsidiária, representação sindical,

13 Conforme tramitação. Disponível em: http://www.camara.gov.br/proposicoesWeb/fichadetramitacao?idProposicao=128886. Acesso em: 20 abr. 2018.

${ }^{14}$ Disponível em: <www.cut.org.br>. Acesso em: 20 mar. 2018. 
terceirização no serviço público. (CRISTINA, 2013; MIRANDA, 2013).

O processo não teve sucesso na construção de uma proposta comum, pois não houve acordo sobre os limites da terceirização na atividade-fim, sobre a garantia da representação sindical dos terceirizados pela entidade que representasse preponderantemente os trabalhadores no local de trabalho e a responsabilidade solidária (CRISTINA, 2013; MIRANDA, 2013; CARVALHO, 2013). Por outro lado, a votação na CCJC ficou paralisada até 2015, quando 0 $\mathrm{PL}$ foi aprovado nessa e nas demais comissões previstas no regimento interno da Câmara dos Deputados. Em seguida, foi aprovada no plenário da Câmara dos Deputados ${ }^{15}$ e enviada para o Senado Federal, onde recebeu nova numeração, PLS 30/2015.

No senado, a Comissão especial do desenvolvimento nacional ficou responsável por realizar o debate sobre a terceirização. O senador Paulo Paim (PT/RS), oriundo do movimento sindical ${ }^{16}$, foi indicado pela comissão como relator dos Projetos de Lei do Senado (PLS) que tratavam do tema. O senador elaborou uma proposta de substitutivo que atendia as principais demandas das centrais sindicais (PAIM, 2016). Em negociação entre o senador, centrais sindicais e o presidente do senado ficou garantindo que o substitutivo iria a voto, o que garantia uma oportunidade para aprovação de uma regulamentação que atendesse a maior parte das reivindicações das representações dos trabalhadores. Nesse cenário, os empresários mudaram a estratégia e apoiaram a retomada da tramitação na Câmara dos Deputados do PL 4302/1998. Em março de 2017, esse projeto foi aprovado ${ }^{17}$ e transformado em Lei número 13.429/2017.

\footnotetext{
15 Conforme tramitação. Disponível em: $<$ http://www.camara.gov.br/proposicoesWeb/fichadetramitacao?idProposicao=267841 $>$. Acesso em: 20 abr. 2018.

${ }^{16}$ Senador Paulo Paim PT/RS, ex-diretor do Sindicato dos Metalúrgicos de Canoas, RS.

${ }^{17} \mathrm{O}$ PL já havia sido aprovado no senado com alterações, e por esse motivo voltou para a Câmara para votação final. Foi sancionado como Lei 13.429/2017.
} 
QUADRO 1 - Projetos de Lei em tramitação no Congresso Nacional, 2016

\begin{tabular}{|c|c|}
\hline Proposições & Ementa \\
\hline PL 4302/1998 & $\begin{array}{l}\text { Dispõe sobre as relações de trabalho na empresa de } \\
\text { trabalho temporário e na empresa de prestação de serviços } \\
\text { a terceiros, e dá outras providências. Projeto do Executivo, } \\
\text { enviado pelo então Presidente Fernando Henrique Cardoso. }\end{array}$ \\
\hline $\begin{array}{c}\text { Mensagem } \\
\text { Presidencial 389/2003 }\end{array}$ & $\begin{array}{l}\text { Solicita a retirada do PL no } 4.302 \text {, de } 1998 \text {, encaminhada } \\
\text { pelo poder executivo. }\end{array}$ \\
\hline PL 4330/2004 & $\begin{array}{l}\text { Dispõe sobre o contrato de prestação de serviço a terceiros } \\
\text { e as relações de trabalho dele decorrentes. Aprovada na } \\
\text { Câmara dos Deputados em } 22 / 04 / 2015 \text { e enviada ao } \\
\text { Senado. }\end{array}$ \\
\hline PL 1621/2007 & $\begin{array}{l}\text { Dispõe sobre as relações de trabalho em atos de } \\
\text { terceirização e na prestação de serviços a terceiros no setor } \\
\text { privado e nas sociedades de economia mista. Apresentado } \\
\text { pelo Deputado Vicentinho, elaborado em conjunto com a } \\
\text { CUT, arquivado em } 2015 \text {. }\end{array}$ \\
\hline $\begin{array}{l}\text { (PL não foi } \\
\text { apresentado) } \\
2009\end{array}$ & $\begin{array}{l}\text { Minuta de PL. Dispõe sobre os contratos de serviços } \\
\text { terceirizados e as relações de trabalho deles decorrentes } \\
\text { celebrados por pessoas de natureza jurídica de direito } \\
\text { privado. Elaborado pelas Centrais Sindicais, Ministério do } \\
\text { Trabalho e Ministério de Assuntos Estratégicos. }\end{array}$ \\
\hline PLS 87/2010 & $\begin{array}{l}\text { Dispõe sobre a contratação de serviços de terceiros. Réplica } \\
\text { do PL 4330/2004. Apresentado por setores do empresariado. }\end{array}$ \\
\hline PLS 447/2011 & $\begin{array}{l}\text { Determina a responsabilização solidária da Administração } \\
\text { Pública e da pessoa jurídica tomadora de serviços, com o } \\
\text { respectivo prestador, pelos encargos previdenciários } \\
\text { resultantes da execução do contrato, e, em caso de dolo ou } \\
\text { culpa, pelos encargos trabalhistas. Propõe regulamentação } \\
\text { para terceirização na administração pública direta e indireta. }\end{array}$ \\
\hline PLS 300/2015 & $\begin{array}{l}\text { Dispõe sobre os contratos de terceirização de mão de obra e } \\
\text { as relações de trabalho deles decorrentes. Reivindica a } \\
\text { Súmula } 331 / T S T \text { como marco para regulamentação da } \\
\text { terceirização (terceirização apenas nas atividades-meio). }\end{array}$ \\
\hline PLS 30/2015 & $\begin{array}{l}\text { Dispõe sobre os contratos de terceirização e as relações de } \\
\text { trabalho deles decorrentes. PL } 4330 / 2004 \text {, aprovado pela } \\
\text { Câmara dos Deputados e remetido ao Senado, onde } \\
\text { recebeu nova numeração. }\end{array}$ \\
\hline PLS 554/2015 & $\begin{array}{l}\text { Dispõe sobre os contratos de terceirização e as relações de } \\
\text { trabalho dele decorrentes. Proposta elaborada pela entidade } \\
\text { de classe dos juízes do trabalho (Anamatra). Propõe limites } \\
\text { para a terceirização. }\end{array}$ \\
\hline
\end{tabular}

Fonte: DIAP, 2016; Congresso Nacional, 2016/2018; Minuta PL Centrais, documento sem data. 
A Lei aprovada em março de 2017 ( $N^{\circ}$ 13.429) trata das relações de trabalho nas empresas de trabalho temporário e na empresa de prestação de serviços a terceiros. Essa Lei aprofunda as condições precárias de utilização do trabalho temporário, que no Brasil é uma das formas de terceirização. No texto original de 1974, caso a empresa prestadora de serviços não recolhesse as contribuições previdenciárias ou outras verbas rescisórias, a empresa contratante era solidariamente responsável pelo pagamento; o tempo de execução desse contrato era limitado há três meses, podendo ser estendido com autorização do Ministério do Trabalho (geralmente, nos casos de substituição de trabalhadores em licença maternidade); o trabalhador com vínculo empregatício temporário não tinha direito à multa de $40 \%$ sobre 0 Fundo de Garantia por Tempo de Serviço (FGTS) nem ao aviso prévio ao término do contrato (Lei 6019, texto aprovado no ano de 1974).

A nova Lei aprovada em 2017 altera o conceito de trabalho temporário, permitindo seu uso "(...) para atender à necessidade de substituição transitória de pessoal permanente ou à demanda complementar de serviços" ( $\operatorname{Art}^{\circ}$ 2, Lei 13.429/2017), e a demanda complementar de serviços deve ser entendida como aquela "(...) oriunda de fatores imprevisíveis ou, quando decorrente de fatores previsíveis, tenha natureza intermitente, periódica ou sazonal'. ( $\mathrm{Art}^{\circ} 2$, $\S 2^{\circ}$, Lei $13.429 / 2017$ ). No texto de 1974 , o trabalho temporário era permitido apenas para substituição transitória de pessoal permanente ou ainda para acréscimo extraordinário de serviços. Essa alteração permite um uso indiscriminado desse contrato de trabalho, podendo ser utilizado como substituição do contrato de trabalho por tempo indeterminado.

Outra alteração relevante trazida pela Lei 13.429/2017 é que o prazo do contrato de trabalho temporário passa de 90 dias para 180, podendo ser renovado por mais 90 dias. Esses prazos podem ser alterados, inclusive, para um período maior, por intermédio de negociação coletiva com entidade representativa dos trabalhadores. Essa ampliação pode resultar em aumento da rotatividade e redução do número de trabalhadores com contrato por prazo indeterminado.

As empresas dos setores de comércio, serviços, indústria e 
agropecuária podem optar por ampliar parcela da força de trabalho através de contrato temporário em períodos de alta da produção ou aumento da demanda por um serviço, acompanhando a sazonalidade típica de cada setor/empresa, reduzindo o núcleo fixo com contrato de trabalho por prazo indeterminado.

O fato de o contrato temporário ser de no mínimo nove meses é tempo suficientemente longo para cobrir os períodos anuais de alta em qualquer setor econômico. A nova regulação permite ainda que o contrato temporário possa ser utilizado nas atividades-fim e nas atividades-meio, podendo ser utilizado nas três esferas de governo e ainda estende o seu uso para as áreas rurais.

A outra parte da Lei 13.429/2017 trata das empresas prestadoras de serviços a terceiros, definidas como "(...) pessoa jurídica de direito privado destinada a prestar à contratante serviços determinados e específicos" (Art. $4^{\circ}$ A). A prestadora de serviços é responsável pela contratação, remuneração e direção do trabalho realizado por seus trabalhadores, podendo ainda subcontratar outras empresas para realização desses serviços.

A Lei também libera o dispositivo da Pejotização e da quarteirização. As empresas "PJ" (Pessoa Jurídica) são aquelas formadas por apenas uma pessoa, o próprio trabalhador, alterando a relação contratual de trabalho para relações contratuais entre empresas. A quarteirização se dá quando a empresa terceira repassa parte ou toda a execução dos serviços para o qual foi contratada para outra empresa, estabelecendo uma longa cadeia de subcontratações que permite novas formas de trabalho precário e que facilita ainda mais a liberação da empresa contratante de prejuízos com reclamações trabalhistas, também chamada de terceirização em cascata (MARCELINO; CAVALCANTE, 2012).

Os requisitos definidos nessa Lei para o funcionamento das empresas são insuficientes para evitar o caráter de interposição da força de trabalho e os recorrentes calotes das empresas terceirizadas para com seus trabalhadores que ficam sem receber salários, benefícios e verbas rescisórias. Por exemplo, uma empresa com até dez funcionários precisa apenas comprovar um capital 
social ${ }^{18}$ de $R \$ 10.000,00$, valor insuficiente sequer para quitação de verbas rescisórias em caso de finalização de contratos de prestação de serviços ou ainda, de falência da empresa terceira.

Na parte da Lei 13.429/2017 que trata das empresas prestadoras de serviço é novamente reforçada a ideia de que não se "(...) configura vínculo empregatício entre os trabalhadores, ou sócios das empresas prestadoras de serviços, qualquer que seja o seu ramo, e a empresa contratante" (Art. $2^{\circ}$, $\S$ $2^{\circ}$ ), além de reafirmar a responsabilidade subsidiária. A empresa contratante é responsável pelas condições de segurança, higiene e salubridade dos trabalhadores e pode optar, ou não, por estender ao trabalhador terceirizado o mesmo atendimento médico, ambulatorial e de refeição destinado aos trabalhadores diretamente contratados.

Apesar de o texto ter sido aprovado, restaram dúvidas sobre seu alcance e a segurança jurídica pretendida pelas empresas, especialmente para aqueles que utilizam ou pretendem utilizar a terceirização nas atividades-fim. No que se refere à terceirização da atividade-fim, novas medidas foram adicionadas a essa regulação através da Reforma Trabalhista, aprovada em julho de 2017, com a inclusão de novo texto que tornou expressamente legal a terceirização em qualquer atividade da empresa, inclusive na atividade principal:

Considera-se prestação de serviços a terceiros a transferência feita pela contratante da execução de quaisquer de suas atividades, inclusive sua atividade principal, à pessoa jurídica de direito privado prestadora de serviços que possua capacidade econômica compatível com a sua execução (Art. o 4-A, Lei 13.467/2017).

Contratante é a pessoa física ou jurídica que celebra contrato com empresa de prestação de serviços relacionados a quaisquer de suas atividades, inclusive sua atividade principal (Art. o 5-A, Lei 13.467/2017).

A Reforma Trabalhista aprovou ainda alteração que atinge as empresas prestadoras de serviços: as garantias de isonomia de direitos opcionais

\footnotetext{
${ }^{18}$ Investimento inicial levantando pelo(s) proprietário(s), correspondente ao patrimônio líquido da empresa, Sebrae. Disponível em: $<$ http://www.sebrae.com.br/sites/PortalSebrae/artigos/entenda-o-que-e-capitalsocial,1e5820fa9d237510VgnVCM1000004c00210aRCRD>, Acesso em: abr. 2018.
} 
prevista na Lei aprovada em março (Lei 13.429/2017) se tornaram obrigatórias, mas se resumem à alimentação e ao transporte interno à empresa (o que, inclusive, facilita a logística interna do empregador), ao treinamento (o que demonstra que a expertise é da contratante e não da contratada/terceirizada, desmistificando a justificativa da especialização dos defensores da terceirização) e às medidas sanitárias e de saúde e segurança. Essas medidas continuam opcionais, quando as atividades não se realizam nas dependências da contratante. Por fim, a Reforma estabelece que salários e outros direitos e benefícios possam ser estendidos aos terceirizados se for da vontade da empresa contratante.

Em agosto de 2018, em decisão do STF, as dúvidas sobre a validade das regras aprovadas nas Leis 13.429/2017 e 13.467/2017 foram definitivamente afastadas. $O$ Tribunal decidiu que toda forma de terceirização ou qualquer outra forma de divisão do trabalho entre pessoas jurídicas distintas é licita, independentemente da atividade das empresas envolvidas e desde que mantida a responsabilidade subsidiária da empresa contratante, sob os argumentos de garantir a competitividade das empresas, de que a terceirização gera empregos e de que abusos devem ser fiscalizados e punidos pela justiça (STF, 30/08/2018).

A regulação da terceirização no Brasil tem algumas características que são relevantes destacar. A primeira delas é que as principais Leis que permitiram maior disseminação desse processo foram aprovadas em período antidemocráticos, a Lei 6019/1975, a Lei 200/1997 e a Lei 7.102/1983 durante a ditadura militar. As Lei 13.429/2017 e 13.467/2017 foram aprovadas durante um governo que chegou à presidência em um processo de impeachment sem crime de responsabilidade, em um golpe parlamentar ${ }^{19}$ que contou com o apoio do Congresso Nacional e do STF.

No Brasil, o conteúdo das regras definidas para regular a terceirização é marcado pela redução contínua das garantias aos trabalhadores e pela ampliação da "segurança jurídica" para os empresários. A cada nova Lei, novos

\footnotetext{
${ }^{19}$ Termo utilizado por Ricardo Antunes, para caracterizar a destituição de Dilma Rousseff. In Fenomenologia da crise brasileira, Revista Lutas Sociais, São Paulo, vol.19 n.35, p.09-26, jul./dez. 2015. Disponível em: < https://revistas.pucsp.br/ls/article/viewFile/26672/pdf>.
} 
setores são liberados para a terceirização até as novas proposições aprovadas em 2017, que liberam a terceirização para todos os setores e todas as áreas de uma empresa.

O termo "insegurança jurídica" é fartamente utilizado pelos empresários quando o assunto é a regulação da terceirização. Segundo Krein (2017) a alegada "segurança jurídica" busca eliminar os entraves que a regulação pública do trabalho coloca à exploração capitalista, criando um novo padrão em que se busca compartilhar os riscos do negócio com o trabalhador. O resultado é a apropriação cada vez mais desigual da renda do trabalho. Nesse caso, a segurança jurídica defendida pelas empresas libera o empregador para adotar toda e qualquer medida que the for mais conveniente na relação de emprego, mesmo que isso submeta milhões de trabalhadores à insegurança ou à vulnerabilidade. A reforma trabalhista de 2017 (incluindo as novas regras para a terceirização) reforça a ideia de que os interesses privados prevalecem sobre direitos coletivos do trabalho (KREIN, 2018) Ou seja, a segurança jurídica de uns, significa a insegurança (jurídica, alimentar, de moradia etc.) de outros.

Souto Maior (2017) faz uma reconstituição histórica sobre os direitos trabalhistas para desmistificar o recorrente uso pelos empregadores do termo "insegurança jurídica". Para o sistema capitalista funcionar é necessário que os trabalhadores se submetam a vender sua força de trabalho e o direito do trabalho é uma engrenagem para atraí-los para o mercado de trabalho garantindo compensações, mas também estipulando as regras de submissão dos trabalhadores. Destaca Souto Maior ainda, que, nos países de capitalismo central, os direitos do trabalho surgem como forma de superar os princípios jurídicos liberais (que contribuíram com um tipo de capitalismo desorganizado e que resultaram, em conjunto com outros fatores, as duas guerras mundiais) e de reduzir as grandes tensões sociais resultado das péssimas condições de trabalho. E mais, como os capitalistas também estão submetidos à lógica do capital, concorrendo com outros capitalistas, necessitam de regras mínimas.

No Brasil, mesmo com todas as particularidades e limites, esse movimento também se deu com a legislação do trabalho. Aqui, os direitos trabalhistas nunca assumiram a importância regulatória da legislação de fato e sempre foram deliberadamente desrespeitados pelos empregadores. É 
resultado desse desrespeito às regras (e não da complexidade da legislação), o enorme número de reclamações trabalhistas na Justiça do Trabalho: mais de $40 \%$ das reclamações têm como objeto verbas rescisórias não pagas - ou seja, temas com legislação bastante clara sobre o que deveria ser pago. Destaca-se que, segundo o autor, a atuação histórica da Justiça do Trabalho colabora com a ineficiência da legislação trabalhista brasileira: há segmentos empresariais que descumprem a legislação trabalhista deliberadamente, como uma estratégia de gestão, e se apoiam nos acordos proposto na Justiça do Trabalho (que ocorrem com a redução do pagamento do valor devido) e na ausência de punição judicial (SOUTO MAIOR, 2017).

Para Souto Maior (2017), quem convive com insegurança jurídica nas relações de trabalho no Brasil são os trabalhadores: quase a totalidade dos processos trabalhistas abertos na justiça é realizada pelos trabalhadores, e não pelos empregadores; e também, na grande maioria dos casos, a reclamação é pertinente. A CLT, como foi imaginada em 1943, dava pouca margem para insegurança jurídica nos termos propagados pelos empresários, pois garantia direitos como limitação da jornada de trabalho, salário, férias, períodos de descanso, etc. Aos poucos, a legislação trabalhista foi ficando mais complexa não porque os direitos tenham aumentado, mas porque foi sendo alterada para atender demandas das reivindicações patronais, criando "brechas" e exceções. A terceirização é um desses casos: quando as empresas passaram a terceirizar suas atividades, a Súmula 331 do Tribunal Superior do Trabalho TST passou a autorizar a terceirização na atividade-meio. Assim, aconteceu com o contrato por prazo determinado, com o contrato de aprendiz, com o banco de horas, etc. E conclui Souto Maior (2017, p. 36):

Essa situação de insegurança jurídica dos trabalhadores, proporcionada pelas normas de flexibilização e pela ameaça de desemprego, acompanhadas da impossibilidade de reação institucional dos trabalhadores, dada a fragilização do sindicalismo e da força repressiva estatal, o qual atribuiu para si o papel de levar adiante o projeto neoliberal, conduziu os trabalhadores a um estágio de submissão e os empregadores à plenitude da soberba. Isso permitiu o advento de uma concepção empresarial no sentido de que deixar de aplicar direitos já não era o bastante, vez que passava a ser possível desenvolver 
uma forma de tratamento que assumia o caráter descartável do trabalhador.

Em resumo, as sucessivas reivindicações dos empresários para alterar a legislação trabalhista buscando reduzir direitos, acompanhadas da noção de que direito trabalhista não precisa ser respeitado e de uma Justiça de Trabalho que não atua para preservar o direito, acabam gerando situações de insegurança jurídica, mas isso como resultado da implementação de uma intenção juridicamente inconcebível, a de precarizar as condições de trabalho e com isso reduzir custos. O uso desse termo, portanto, faz alusão a algo real para entorno desse aspecto do rela, criar uma ilusão ideológica sobre a totalidade do fenômeno.

Os empresários apresentam a terceirização como fruto da reengenharia da produção, necessária para a competitividade porque garante maior flexibilidade administrativa para as empresas, justificam a regulação da terceirização como forma de garantir segurança jurídica, supostamente, também para os trabalhadores. Mas não há segurança jurídica para quem não tem vínculos duradouros e que são incorporados como corpos estranhos no ambiente de trabalho (SOUTO MAIOR, 2015).

Ao longo do período de expansão da terceirização, especialmente a partir da segunda metade dos anos 1990, os empresários definiram esse tema como prioritário, mas enfrentaram a resistência organizada pelo movimento sindical brasileiro. Se, por um lado, o sindicalismo não conseguiu evitar a difusão dessa prática no Brasil, que muitas vezes se deu à revelia da Lei vigente, por outro, foi capaz de resistir por mais de 30 anos à atual regulação, que aprofunda as características de precarização das condições e relações de trabalho.

Os setores patronais afirmam que a terceirização é uma estratégia de especialização da produção e dos serviços que gera ganhos de produtividade e qualidade, e que seu objetivo não é precarizar o trabalho. No entanto, não aceitaram a inclusão de nenhuma alteração proposta pelas Centrais Sindicais que objetivamente poderia proteger o trabalhador terceirizado ou ainda uma definição para especialização produtiva e de serviços. Para os empresários o fundamental era que a Lei continuasse a permitir a ampliação da exploração da 
força de trabalho terceirizada, ampliando a terceirização para um número maior de trabalhadores, alocados na atividade-fim das empresas. Em outras palavras, importava a permissão para ampliar a terceirização como instrumento de redução do custo do trabalho e, ainda, com segurança jurídica.

Os governos de Luís Inácio Lula da Silva e Dilma Rousseff de 2003 a 2016, pressionados pelo movimento sindical, evitaram que ocorresse a aprovação dos projetos de Lei que liberavam a terceirização enquanto estiveram no poder. Por outro lado, também não apresentaram ao Congresso Nacional a proposta construída pelas Centrais Sindicais.

Esses governos foram resultado de uma frente política ampla e heterogênea, e contaram com o apoio de uma fração da burguesa interna (MARCELINO, 2017). Essa fração também pressionou Lula e Dilma para garantir uma regulamentação para a terceirização, que atendesse aos seus interesses de classe. Nesse cenário, os governos de Lula e Dilma optaram por serem mediadores do conflito e não representantes dos trabalhadores, com quem possuem ligações históricas.

Os desdobramentos da aplicação dessa nova Lei ainda estão em curso, especialmente porque os empresários aguardavam a decisão final do STF, que só ocorreu em agosto de 2018. A nova regulamentação da terceirização no Brasil está em fase de experimentação e implementação pelos setores empresariais, inclusive pelo Estado. Muito provavelmente será utilizada em conjunto com os demais tipos de contratos de trabalho precários instituídos ou ampliados pela Reforma Trabalhista (contrato intermitente, autônomo exclusivo, tempo parcial, teletrabalho) - um cardápio de contratos precários que irão se adequar à lógica do capital, reforçando o caráter já segmentado da força de trabalho no Brasil.

Em pesquisa realizada pelo DIEESE/CUT, sobre os efeitos da reforma trabalhista para as negociações coletivas no primeiro semestre de 2018, dentre os contratos de trabalho precários instituídos pela reforma trabalhista, a terceirização foi o contrato que apareceu com destaque nas pautas apresentadas pelos empresários, ao lado do contrato de trabalho intermitente. 
Em $27,8 \%$ das pautas patronais ${ }^{20}$ esse tema foi apresentado, ou seja, mesmo com um cardápio de novos contratos de trabalho precários aprovados pela reforma trabalhista, a terceirização parece continuar a figurar como a principal forma de redução de custos do trabalho. O objetivo dos empresários, ao apresentar a terceirização como tema na pauta de negociação das diversas categorias analisadas no estudo, era o de ampliar a legitimidade desse tipo de contratação após a aprovação das novas regras em 2017. Lembre-se que, mesmo com a aprovação da reforma trabalhista, ainda restavam dúvidas sobre sua aplicabilidade, especialmente, nas chamadas atividades-fim, e a decisão final do STF ocorreu somente em agosto de 2018. (DIEESE/CUT, 2018).

De todo modo, é possível avaliar que, além da legalização das terceirizações já implementadas à revelia da Lei ao longo das últimas décadas, haverá uma ampliação da terceirização em suas diversas formas. Esse processo poderá significar uma precarização ainda mais intensa no mercado de trabalho porque dentre as formas permitidas, aquelas que assumem 0 caráter de interposição de mão de obra foram liberadas. A nova regulamentação também poderá reforçar a fragmentação sindical, dificultando ainda mais as estratégias de atuação coletiva contra a subcontratação.

Ao longo desse processo de difusão da terceirização e de formalização de regras para sua implantação de modo irrestrito, os conflitos de interesses entre empresários e trabalhadores se acirram e se tornou uma das principais questões em nível nacional para as entidades de classe. A grande maioria das ações nacionais das centrais sindicais tinha como pauta 0 combate à terceirização. Para os empresários a terceirização também figura como ponto central de sua pauta. Considerando esse acirramento e o fato de ser considerada uma das principais pautas para ambos os lados, é possível que a ampliação dos processos de terceirização registre novos conflitos.

As disputas entre os setores patronais e de trabalhadores em torno do conteúdo da regulamentação da terceirização é expressão de suas posições de classe. Mas essas posições ultrapassam as disputas da burguesia e dos

\footnotetext{
${ }^{20}$ Segundo a pesquisa, é a primeira vez que os sindicatos patronais apresentaram uma pauta ampla de "reivindicações", situação relatada em 76 das 79 negociações analisadas que ocorreram no $1^{\circ}$ semestre de 2018 . Em geral, os sindicatos patronais apresentavam um ou outro tema na mesa de negociação, mas nunca uma pauta estruturada(DIEESE/CUT, 2018).
} 
trabalhadores, elas estão presentes também nas concepções e definições sobre o que significa o processo de terceirização na produção acadêmica, como veremos na seção seguinte.

\subsection{Especialização produtiva versus precarização do trabalho - os interesses de classe envolvidos na disputa em torno da terceirização no Brasil}

Com o desenvolvimento do capitalismo, diferentes padrões de organização industrial foram sendo implementados na busca de diminuir o tempo do capital imobilizado, de aumentar a produtividade, de reduzir custos, com a produção e com o trabalho, e também de ampliar o controle sobre 0 trabalhador.

Com o esgotamento do ciclo de desenvolvimento após a Segunda Guerra Mundial, na década de 70 novos modelos de organização produtiva foram desenvolvidos com objetivo de promover um novo padrão de acumulação de capital. Entre as novas formas de organização produtiva destaca-se o toyotismo, consolidado a partir de experiências adotadas durante a década de 50 no Japão. Esse modelo se espalhou por diversos países, apesar de apresentar características próprias em cada local, de acordo com a realidade social, cultural, política e econômica. Com as mudanças introduzidas pelo toyostismo, uma nova base tecnológica foi implantada, possibilitando uma produção mais flexível, a garantia de maior mix de produtos, que se adaptava às mudanças repentinas no mercado consumidor, e reduzia o tempo do capital imobilizado e os custos com o trabalho (ANTUNES, 2003).

No Brasil, assim como ao redor do mundo, um dos principais instrumentos utilizados para a implementação desse novo modelo de organização produtiva flexível foi a terceirização. Ela surge com a vinda do setor automotivo no final da década de 1950, que apresentava como discurso de legitimação a necessidade de se concentrar na atividade principal, a montagem de carros, com benefícios relacionados à qualidade, produtividade $\mathrm{e}$ competitividade, transferindo para as empresas terceiras algumas atividades, em especial a produção de peças. Mas é no final da década de 1980 e, 
principalmente nos anos 1990 que a terceirização é fortemente utilizada como estratégia de organização das empresas e de redução dos custos com 0 trabalho (JORGE, 2011).

As novas formas de organizar a produção aprofundaram a precarização do trabalho no Brasil. Esse processo foi facilitado pelo nosso padrão de regulação do emprego já existente e com regras bastante limitadas para a proteção ao trabalhador. O sentido desse processo é garantir maior liberdade para as empresas na determinação das condições de uso, de contratação e de remuneração do trabalho, possibilitando também ajustes no volume e no preço da força de trabalho (KREIN, 2007).

Como parte desse processo, o advento da terceirização instaurou uma nova dinâmica nas relações de trabalho que afetou os direitos, aumentou a ocorrência de acidentes e doenças, e também interferiu de forma importante na organização sindical, pulverizando a representação dos trabalhadores, interferindo também nas relações de cooperação e de solidariedade entre os trabalhadores e do estabelecimento de identidades coletivas, além de facilitar o descumprimento da legislação trabalhista no uso da força de trabalho e da sua exploração como mercadoria (ANTUNES \& DRUCK, 2013).

As condições de trabalho entre os trabalhadores terceirizados são marcadas por menores salários, menor tempo de emprego, maiores jornadas de trabalho e maior rotatividade, maiores índices de acidente e doenças de trabalho, quando comparadas aos trabalhadores diretamente contratados pela empresa principal. Além das desvantagens nas condições de trabalho e salários, os trabalhadores terceirizados frequentemente ficam desprotegidos no encerramento dos seus contratos de trabalho, principalmente nos setores de vigilância e asseio e conservação em que os "calotes" são constantes: as empresas encerram suas atividades e os trabalhadores não recebem as verbas indenizatórias às quais têm direito com o fim do contrato. (CUT/DIEESE, 2011).

Portanto, a terceirização do trabalho não é apenas uma ferramenta para tornar a produção flexível, facilitando a ampliação ou redução da base produtiva e dos estoques de força de trabalho e o ajuste aos ciclos produtivos ao transformar gastos fixos em variáveis. Ela é, principalmente, um importante instrumento para as empresas reduzirem o custo com 0 trabalho 
(MARCELINO, 2002).

Vale lembrar que formas precárias no mercado de trabalho brasileiro não é novidade, trata-se de característica estrutural do capitalismo periférico. Desde a sua regulação, no início dos anos 1930, a legislação criada estabelecia grande margem para que a força de trabalho fosse utilizada ao sabor das necessidades exclusivamente empresariais. Já no início dessa regulação, ficaram de fora os trabalhadores rurais e empregados domésticos, imprimindo ao mercado de trabalho brasileiro características como a alta informalidade ou trabalho por conta-própria, a alta rotatividade e baixa cobertura previdenciária. Aliado a esses fatores, temos as características da estrutura econômica em progresso (industrial com participação estatal e de capital multinacional) e as opções para o desenvolvimento no Brasil (urbano e concentrador de riquezas) observada dos anos de 1930 aos anos de 1980. Podemos ainda destacar como características do mercado de trabalho o excedente estrutural da força de trabalho, ocupações com necessidade de baixa qualificação formal e profissional e baixos salários (KREIN, 2007).

Mas a precarização resultante da terceirização é característica inata do processo ou uma implementação equivocada desse dispositivo?

Recentemente, algumas matérias em jornais de circulação nacional registraram a fala de ministros de Estado, empresários, alguns líderes de partidos, especialistas e acadêmicos, afirmando que a Lei aprovada em março de 2017 tratando da terceirização não representava retirada de direitos. Essa afirmação era fundada no fato de o contrato de trabalho e demais direitos regidos pela Consolidação das leis do Trabalho (CLT) e pela Constituição Federal serem iguais para trabalhadores diretamente contratados pelas empresas e para aqueles que exerciam suas atividades através de empresas terceiras.

Esse argumento foi repetido incansavelmente pelos setores que apoiavam os interesses empresariais e foi divulgado amplamente por alguns setores da mídia, como retratam os títulos de matérias veiculadas no período em que a nova regulamentação foi aprovada: "Especialistas consideram que projeto pode trazer mais competitividade ao país e alertam que carteira assinada não será eliminada" (O Correio Brasiliense, 25/03/2017) e 
"Terceirização não tira direitos, diz ministro do Trabalho" (Estadão, 01/04/2017).

Esse discurso procurava reforçar uma definição de terceirização como um expediente capaz de ampliar os ganhos de produtividade e de qualidade através da especialização da atividade das empresas - discurso amplamente divulgado pelas entidades de classe patronais, como vimos acima.

Nos estudos acadêmicos essa abordagem é bastante presente nas áreas de administração, de economia e do direito, nos quais se afirma que os possíveis erros de aplicação desse mecanismo no Brasil, que resultam em descumprimento da legislação trabalhista, se devem ao fato das empresas não observarem os critérios de implementação previsto nos manuais, ou, devido às características históricas e de estrutura dos setores de atividade econômica nacionais, ou ainda, devido à falta de uma regulamentação com segurança jurídica (LEIRIA, 1992; VALENÇO e BARBOSA, 2002; SOUZA, MALDONADO e RADOS, 2011; ZYLBERSTAJN, 2015).

Mas por outro lado, os trabalhadores e especialmente os trabalhadores terceirizados têm bastante clareza sobre os efeitos da terceirização. A matéria "Terceirização não derruba salários" (Folha de São Paulo, 03/09/2017) apresentava dados estatísticos que procuravam demonstrar que a subcontratação não resultava em perda para os trabalhadores. Os autores da pesquisa afirmavam que o estudo desmontava o mito de que a terceirização precarizava os salários. Destacaram como hipótese para um suposto malentendido a demonização da terceirização feita pelos sindicatos (que nessa organização produtiva tinham dificuldades adicionais para organização dos trabalhadores) e também porque uma parte das empresas terceiras tinha como prática o não recolhimento de encargos, o que seria facilmente resolvido com mais fiscalização.

Sem entrar nos detalhes da pesquisa e de sua metodologia, interessa destacar a reação dos leitores ao título e ao conteúdo da matéria. O jornal recebeu tantos comentários negativos, considerando que a pesquisa não retratava a realidade, que foi preciso uma resposta da ombudswoman. $\mathrm{Na}$ coluna intitulada "A precisão no despenhadeiro" (Folha de São Paulo, 10/09/2017) a jornalista inicia o texto dizendo que a matéria com os resultados 
da pesquisa foi campeã de reclamações do jornal. Os leitores declararam que a manchete era enganosa, que o conteúdo era enviesado e perigoso, e que mesmo uma pequena redução dos salários dos terceirizados, significaria muito para aqueles com menores rendimentos.

A terceirização teve grande expansão nas últimas décadas e possivelmente, uma parcela considerável da população tem contato direto ou indireto com esse processo. Conhecendo os efeitos concretos da sua aplicação é bastante improvável que uma matéria como a citada convenceria os leitores do contrário.

A crítica elaborada por Marcelino e Cavalcante (2012) sobre as definições que reforçam a ideia da terceirização como um fenômeno dual auxilia nesse debate. As definições que afirmam ser a terceirização um processo moderno, que possibilita às empresas a focalização de suas atividades no seu negócio principal (as atividades-fim), delegando para outras empresas os processos acessórios. Estes, por sua vez, se constituiriam como foco dessas outras empresas (as atividade-meio), em um processo de ganhaganha, em relações de cooperação, com ganhos de produtividade para todos. Segundo os autores que comungam dessa definição, no Brasil estaria ocorrendo uma forma distorcida de implementação da terceirização, que resultaria em precarização do trabalho.

Essa dualidade - a terceirização apresenta ganhos fruto da especialização, mas é mal aplicada no Brasil - acabou permeando muitos estudos nos diversos campos de conhecimento que analisam os processos de terceirização no Brasil. Essas concepções também contaminaram as avaliações e ações do movimento sindical em relação a esse fenômeno.

Uma das definições é a apresentada por Abreu e Sorj (1994) que destacam dois tipos de terceirização: uma marcada pelos ganhos de qualidade, produtividade e inovação tecnológica; outra, definida como "terceirização por contingência", tendo como objetivo apenas a redução dos custos de produção.

Outro autor que também afirma existir dois tipos de terceirização é Faria (1994): a primeira seria o "outsourcing global" que buscava ganhos de produtividade e condições novas de competitividade, em uma relação de 
ganha-ganha entre empresa contratante e empresa terceirizada; e o "outsourcing tupiniquim", uma implementação da terceirização como estratégia do confronto entre empregador e empregados e suas organizações sindicais, com objetivo de reduzir os custos com a força de trabalho, cujo resultado é o ganha-perde.

Essa concepção dual sobre a terceirização também se difundiu para 0 movimento sindical brasileiro. O Sindicato dos Metalúrgicos do ABC (SMABC, 1993) destacava entre os efeitos negativos da terceirização a fragilização da ação sindical e a precarização dos trabalhadores terceirizados através da redução da remuneração e dos benefícios, do aumento da jornada, da piora nas condições de saúde e segurança, entre outros. Frente a isso, as propostas de ação sindical buscavam garantir que a representação dos trabalhadores terceirizados ficasse com 0 sindicato preponderante da categoria (metalúrgicos), que houvesse informações e negociação sobre o processo de terceirização, treinamento e realocação de pessoal afetado, garantia de isonomia de direitos, além do combate à terceirização predatória (significa que há outra que não é predatória). Dessa forma, aceitavam que poderia existir um tipo positivo de terceirização.

Um exemplo dessa aposta do movimento sindical pela negociação do processo de terceirização foi a assinatura do um Acordo Coletivo de Trabalho (ACT) em abril de 1994, entre Mercedes-Benz, em São Bernardo do Campo (MBB/SBC), a Comissão de Fábrica (CF) e o SMABC. A avaliação do sindicato era que o processo de expansão da terceirização era inevitável e a negociação da implantação da terceirização poderia estabelecer garantias aos trabalhadores. A negociação da terceirização fez parte de um processo negociado da implementação da Reestruturação Produtiva, que englobava 18 ACTs $^{21}$ (PAULINO; MARCOLINO, 1999).

O ACT sobre a terceirização foi elaborado com o objetivo de aumentar a competitividade, a flexibilidade e a especialização da produção para aumentar

\footnotetext{
${ }^{21}$ Ao todo foram analisamos 18 acordos firmados no período de 1990 a 1998. A partir de 1993, ACTs ligados mais diretamente com a questão da Reestruturação Produtiva começaram a ser assinados, entre os quais citamos os mais relevantes: alteração de cargos e funções (1993 e 1997), terceirização (1994), células de manufatura (1994), melhorias contínuas (1995), trabalho em grupo (1995), PLR (1995, 1997 e 1998), flexibilidade da jornada de trabalho (1996) e contrato por tempo determinado (1998). (PAULINO; MARCOLINO, 1999).
} 
a qualidade e a produtividade, consideradas nas negociações de Participação nos Lucros e Resultados (PLR) regulado por outro ACT. Os postos de trabalho que fossem afetados com a terceirização de algum setor teriam o seguinte encaminhamento: o trabalhador seria realocado para outro posto de trabalho; poderia ser admitido pela empresa prestadora do serviço ou, como último recurso, o trabalhador seria cadastrado em entidades voltadas à recolocação de pessoal no mercado de trabalho. A empresa prestadora seria obrigada a garantir as normas de segurança e medicina do trabalho e o recolhimento dos encargos sociais (PAULINO; MARCOLINO, 1999).

No entanto, no segundo semestre de 1995, a empresa desrespeitou os acordos de manutenção do nível de emprego, inclusive o que tratava de terceirização, e demitiu 1.500 trabalhadores das plantas de Campinas e São Bernardo do Campo, alegando queda na produção. Após esse evento, teve início a implantação da reestruturação produtiva à revelia do que havia sido negociado nos 18 acordos que tratavam direta ou indiretamente do tema.

No caso da terceirização, vários setores da planta da MBB/SBC foram terceirizados, tanto nas áreas produtivas como nos serviços de apoio. Nos dois primeiros anos do ACT/Terceirização (1994-1995), período em que ocorreu a maioria dos casos de terceirização, cerca de 700 trabalhadores horistas diretos e 150 indiretos da MBB/SBC foram transferidos para outros postos de trabalho. Mas segundo diretores da CF, na primeira oportunidade, a empresa demitiu esses trabalhadores realocados sob o argumento de que não tinham treinamento adequado e, segundo a avaliação da empresa, não eram eficientes em seus novos postos de trabalho (PAULINO; MARCOLINO, 1999).

Ou seja, mesmo tendo de um lado, um sindicato com forte organização sindical e representatividade junto aos trabalhadores e outro lado, uma grande empresa de ponta da cadeia produtiva, não foi possível garantir direitos aos trabalhadores terceirizados.

Marcelino e Cavalcante (2012) apresentam uma definição que busca ser um instrumento do ponto de vista analítico, constituído a partir dos elementos característicos da implementação da terceirização na prática, tratados em diversos estudos empíricos que, apesar de serem em número bastante expressivo, não apresentam uma definição conceitual mais precisa sobre o 
fenômeno. Essa perspectiva procura estabelecer um diálogo com a produção acadêmica que analisou as formas e consequências da reestruturação produtiva no Brasil, difundida de forma mais consistente na década de 80 e 90 e que, em alguns casos, criou o que os autores chamaram de dilema da dualidade.

Como alternativa a essa visão da terceirização, os autores irão resgatar duas definições alternativas. A primeira, proposta por Druck (1999), quando rejeita a ideia de que os efeitos negativos da terceirização no Brasil se devem a uma prática distorcida de sua implementação, isso porque a terceirização é uma das estratégias inseridas no processo de reestruturação produtiva, em escala mundial, que busca novas formas de acumulação do capital, com o objetivo de reduzir o custo do trabalho e a resistência organizada dos trabalhadores. A segunda é a proposta por Ruduit-Garcia, que diferencia os processos de subcontratação e de terceirização.

Considerando as relações concretas estabelecidas entre empresas e trabalhadores e a tendência de precarização do trabalho que se distancia da idealização proposta sobre a terceirização, e ainda que sem a sistematização da totalidade dos estudos sobre a terceirização e seus efeitos para os trabalhadores, os autores destacam ser possível afirmar que há indícios suficientes para comprovar que a terceirização leva à precarização, em maior ou menor grau, das relações de trabalho e emprego. Ainda colaborando para um núcleo cada vez menor de trabalhadores relativamente estáveis e um grupo que se expande cada vez mais, com auxílio da terceirização e de outras formas, como a subcontratação, para formas precárias de trabalho. A definição de terceirização de Marcelino e Cavalcante (2012, p. 338) é, portanto:

(...) todo processo de contratação de trabalhadores por empresa interposta, cujo objetivo último é a redução de custos com a força de trabalho e/ou a externalização dos conflitos trabalhistas. Ou seja, é a relação na qual o trabalho é realizado para uma empresa, mas contratado de maneira imediata por outra. Na realidade brasileira, a terceirização é inseparável da ampliação da exploração do trabalho, da precarização das condições de vida das classes trabalhadoras. $\mathrm{E}$, certamente, ela não teria a abrangência que tem hoje se não fosse a sua capacidade de reduzir custos - e, portanto, de servir como poderoso 
instrumento para a recomposição das taxas de lucro - e de transferir para outras empresas (as contratadas) 0 "problema trabalhista", a necessidade de administração da força de trabalho e de negociação com ela e seus sindicatos.

Todos os outros elementos envolvidos nesse debate não são constantes: a atividade-fim e a atividade-meio, a capacidade técnica das empresas terceiras, a ampliação da qualidade dos produtos e serviços. $O$ centro do debate é a "(...) desvinculação do trabalhador com a empresa que lucra com a venda de produtos ou serviços criados por seu trabalho" (MARCELINO E CAVALCANTE, 2012, p. 343).

Nessa definição, são formas de terceirização: o trabalho em cooperativas de trabalhadores, que prestam serviços para uma empresa; empresas externas, que pertencem a uma rede de fornecedores (por exemplo, autopeças para as montadoras); empresas externas contratadas para tarefas específicas (teleatendimento); empresas de prestação de serviços internos à contratante (asseio e conservação, manutenção, segurança, etc.); as empresas de personalidades jurídicas (os PJs); a quarteirização ou terceirização em cascata. Pouco importa se o contrato de trabalho na empresa terceirizada é informal, temporário, indeterminado, cooperado.

Por outro lado, as formas de subcontratação seriam trabalho domiciliar se não houver empresa interposta nessa relação; trabalho autônomo, pois a relação desse trabalhador é diretamente com a empresa contratante, ainda que seja um "falso conta própria"; as joint ventures, pois são contratos em que empresas partilham interesses similares.

Adotamos essa definição por considerar que a visão dualista reforça a posição ideológica patronal, defendida durante todo o processo de disputa em torno da regulamentação da Lei sobre a terceirização, e porque ignora o que na prática ocorre, indicado por diversos estudos. Considerando que a terceirização tem efeitos negativos para os trabalhadores é que nos propomos a realizar um balanço das teses e dissertações que tratam do tema terceirização e seus efeitos sobre as condições de trabalho. Procuramos consolidar uma análise nacional a partir dos diversos estudos de caso disponíveis, com indicadores que possibilitem uma leitura mais geral do processo. 
Há uma variedade de concepções nas teses e dissertações sobre quais formas assume a terceirização na prática, portanto, além da utilização da definição, as formas de terceirização destacadas pelos autores nos fornecem um guia para os estudos que iremos selecionar.

Em relação à precarização, Marcelino (2011, p. 65-67) propõe uma definição que considera o fenômeno como um processo. $O$ termo precarização qualifica as mudanças ocorridas desde a década de 70 , que indica um movimento cujo parâmetro de comparação são as conquistas operárias, seja do Estado de bem estar nos países de capitalismo desenvolvido ou do desenvolvimentismo em países como o Brasil. Em nosso estudo, consideramos o período que analisaremos como continuidade desse processo, mas que traz consigo particularidades relacionadas ao quadro que se inicia pós 2008. É como uma espiral descendente: em cada volta há uma expansão da precarização do trabalho e da vida e uma ampliação da quantidade de trabalhadores abrangidos pelo fenômeno. Segundo a autora:

O termo precarização é qualificativo apropriado para 1) as consequências para os trabalhadores da redução dos direitos trabalhistas e da nova forma de atuação do Estado nesta matéria, bem como no oferecimento de mecanismos de proteção social; e 2) as consequências para os trabalhadores da inserção de novas tecnologias, da reorganização do espaço e das hierarquias das empresas, da necessidade da polivalência, da introdução de mecanismo de variação salarial e da incorporação de variadas funções (como controle de qualidade e limpeza) àquela principal do trabalhador (MARCELINO, 2011, p.67).

Nesse capítulo buscamos recuperar as disputas em torno da regulação da terceirização no Brasil, destacando as posições das entidades sindicais e patronais. Ao longo do tempo, houve mudanças na posição do movimento sindical (pelo menos, de parte dele): em primeiro lugar, a de endossar as concepções de dualidade na aplicação da terceirização, e depois, de avançar para a compreensão de que a terceirização é, em todos os casos, precarização das condições e relações de trabalho. Por outro lado, as entidades sindicais patronais sempre se apoiaram no argumento de que existe uma "boa terceirização", aquela que resulta em ganhos de produtividade e qualidade, e ainda, que seriam contrários à terceirização que não respeita as Leis 
trabalhistas - obviamente, a aprovação da Lei 13.429/2017 demonstra que as entidades patronais não estavam preocupadas com as garantias de proteção ao trabalhador.

Como pudemos observar, a concepção de dualidade sobre a terceirização não se restringiu ao ambiente de disputa entre capital e trabalho, mas também permeou o debate acadêmico. $O$ que procuraremos demonstrar nos próximos capítulos é que uma análise da produção acadêmica, sob a ótica do trabalho, não deixa dúvidas: não há dualidade, a terceirização precariza as condições e relações de trabalho, ainda que possa haver diferenças entre a forma como essa precarização ocorre em cada setor de atividade econômica. A construção de um painel com informações de diversos setores, em diversas regiões do país, apoia nossa afirmação, como veremos ao longo dos próximos capítulos. 


\section{Mapeamento da produção acadêmica sobre o tema da terceirização no Brasil - 1995 a 2016}

\subsection{Os avanços e limites dos estudos quantitativos sobre a terceirização}

As estatísticas sobre o mercado de trabalho são bastante relevantes para a análise dos fenômenos que afetam o trabalho e o emprego. Nas últimas décadas, algumas características do mercado de trabalho têm apresentado mudanças a partir do novo padrão de acumulação flexível do capital, com implicações diretas sobre o trabalho e o trabalhador. Reavaliar as estatísticas disponíveis, sua cobertura, a forma de captação dos novos fenômenos presentes no mercado de trabalho é fundamental para garantir a potencialidade dessas informações na elaboração de políticas públicas de emprego e nas análises e estudos realizados pelas instituições públicas, privadas, academia ou ainda para a comunidade internacional (HOFFMANN \& BRANDÃO, 1996; OIT, 1986).

Apesar de a terceirização ser um dos principais fenômenos que atuam sobre o mercado de trabalho no contexto atual, ela é um fenômeno pouco visível aos olhos das estatísticas oficiais ou daquelas produzidas em convênios com instituições privadas. Como destaca Marcelino (2002, p.133) “(...) não existem estudos sindicais, acadêmicos ou mesmo governamentais que apontem a extensão exata da terceirização no Brasil". Os indicadores quantitativos das diferentes pesquisas disponíveis no Brasil possuem limites para avaliar os impactos da terceirização sobre os trabalhadores e suas principais características, porque captam apenas parte do fenômeno ou possibilitam apenas uma estimativa sobre o tamanho da terceirização no mercado de trabalho e de seus efeitos sobre as condições de trabalho (DIEESE/CUT, 2011; ANTUNES e DRUCK, 2013).

O Brasil é signatário da Convenção 160 da Organização Internacional do Trabalho $(\mathrm{OIT}, 1985)$ que trata das estatísticas de trabalho. Essa Convenção orienta que os países devem publicar regularmente as estatísticas básicas do trabalho com informações sobre: 1) população economicamente ativa, 
emprego, desemprego e subemprego, quando existir; b) estrutura e distribuição da população economicamente ativa; c) média de ganhos e média de horas de trabalho; d) estrutura e distribuição dos salários; e) custo da mão de obra; f) índices de preços ao consumidor; g) gastos das unidades familiares e rendimentos das unidades familiares; h) lesões e enfermidades provocadas por acidentes de trabalho; e i) conflitos do trabalho.

Segundo Hoffmann e Brandão (1996), a Convenção 160 é positiva, tem fácil operacionalização e possibilidade de comparação internacional. Essa convenção também avança em relação às orientações anteriores, porque inclui recomendações para acompanhar o subemprego ${ }^{22}$, ampliando a divisão focada apenas em "emprego e desemprego" nas pesquisas sobre o mercado de trabalho. No entanto, as autoras destacam que as recomendações da OIT sempre foram elaboradas pensando, principalmente, nos mercados de trabalho dos países desenvolvidos e, por esse motivo, possuem limites para captar as particularidades de mercados tão heterogêneos como o brasileiro, ainda mais com o crescimento de formas precárias de trabalho ocorrido nas últimas décadas.

Nos mercados mais homogêneos, a classificação em empregados, desempregados e inativos era suficiente (pelo menos, até a década 70 ). No entanto, em mercados heterogêneos a condição de emprego, desemprego e inatividade possuem limites tênues, dificilmente captados pelas estatísticas. Essa heterogeneidade é verificada nos diferenciais de remuneração, inclusive entre trabalhadores com habilidades e qualificação semelhantes, diferenciais de jornada de trabalho, de oportunidades ocupacionais, de mobilidade ocupacional e mobilidade ocupacional geracional, de estabilidade no posto de trabalho, entre outras. Esses aspectos não estariam expressos nas divisões informais/formais, rurais/urbanos, setores modernos/tradicionais e resultam de um processo de desenvolvimento que favorece a existência de condições desiguais na sociedade e no mercado de trabalho (OIT/PREALC, 1986).

\footnotetext{
${ }^{22}$ O tema do subemprego é incluído em 1966. No entanto, somente na década de 80 consolidou-se o aparato conceitual e metodológico para seu acompanhamento (HOFFMANN; BRANDÃO,1996).
} 
Como forma de captar melhor essa condição foi incluído como orientação para as pesquisas nacionais o conceito de subemprego, definido como a "(...) situação em que o emprego de uma pessoa é inadequado em relação a determinadas normas ou a empregos alternativos, tomando como parâmetros a qualificação do indivíduo" (HOFFMANN; BRANDÃO,1996, p. 7).

O subemprego seria detectado considerando aqueles trabalhadores que realizam jornadas de trabalho inferiores às normas do país, não por opção, e que estariam disponíveis e procurando trabalho para horas suplementares. Mas, segundo as autoras, mesmo essa medida tem limites, pois o critério de jornada normal de trabalho não se aplica da mesma forma aos nãoassalariados, muito presentes em países como o Brasil, além do que, a contagem de subemprego poderia esconder formas de desemprego ocultas pelo trabalho precário ou ocultas pelo desalento.

Outro tema que a OIT incluiu foi o trabalho informal em 1972, por considerar que, em países com mercados de trabalho mais heterogêneo com grande disponibilidade de mão de obra, as categorias de emprego, desemprego e subemprego não eram suficientes.

Hoffmann e Brandão destacam que a definição do setor informal para a OIT é de um conjunto de unidades dedicadas à produção de bens ou prestação de serviços com a finalidade de gerar emprego e renda. Esse critério não é suficiente para definir a informalidade no mercado de trabalho brasileiro: aqui, a informalidade não diz respeito apenas às pessoas que trabalham em pequenos negócios, com pouca separação entre trabalho e capital, mas também a uma situação que se inscreve na ilegalidade da falta de registro do vínculo empregatício. Essa definição também não ser suficiente para captar todas as alterações em curso nas últimas décadas, em especial as novas formas de contratação mais precárias.

No caso da terceirização, a possibilidade de captação de dados sobre o mercado de trabalho é limitada a alguns segmentos de trabalhadores subcontratados. A Pesquisa de Emprego e Desemprego (PED) ${ }^{23}$ e a Pesquisa

${ }^{23}$ A Pesquisa abrangem sete regiões metropolitanas e é realizada em conjunto com a Fundação SEADE e órgãos públicos das regiões em que se realiza a pesquisa. Investiga 
Nacional de Amostras por Domicílios Contínua (PNAD Contínua) ${ }^{24}$ possuem em seus questionários apenas a terceirização entre aqueles que executam sua atividade dentro de uma determinada empresa, mas são pagos/contratados por outra empresa (Quadro 2, página 47). Ou seja, elas não consideram a transferência de atividades para empresas terceiras que exerçam a atividade contratada em seus próprios estabelecimentos ou que sejam realizadas em via pública, como, por exemplo, trabalhadores em serviços de leitura de medidores de serviços públicos e os trabalhadores em telemarketing. Essas pesquisas captam também os segmentos terceirizados através de empreiteiras (temporários) e aqueles em cooperativas de trabalho ou produção.

comportamentos típicos de um mercado de trabalho no Brasil: pouco estruturado e com grande disponibilidade de mão de obra (DIEESE/SEADE).

${ }^{24}$ É uma pesquisa amostral de abrangência nacional, que procura satisfazer diversos propósitos, com informações básicas sobre o desenvolvimento socioeconômico e indicadores sobre trabalho e rendimento. Apesar de constar no questionário, o conteúdo dessa informação não é disponibilizado. (IBGE, 2014.). 
QUADRO 2 - Perguntas disponíveis nas principais bases estatísticas sobre o mercado de trabalho no Brasil

\begin{tabular}{|c|c|}
\hline \multirow{2}{*}{$\begin{array}{l}\text { Fluxo do } \\
\text { questionário }\end{array}$} & Pesquisa \\
\hline & PED - Pesquisa de Emprego e Desemprego \\
\hline Pergunta & A empresa onde o sr.(a) trabalha é a mesma que lhe paga? \\
\hline Resposta afirmativa & Se sim, é considerado trabalhador direto. \\
\hline Resposta negativa & $\begin{array}{l}\text { Se não, é questionado: "Qual a atividade do negócio ou da } \\
\text { empresa que lhe paga?" e em seguida: "Quem Ihe fornece os } \\
\text { instrumentos e os materiais necessários para seu trabalho?", } \\
\text { com a possibilidade de reposta: (1) A empresa que lhe paga; } \\
\text { (2) A empresa onde exerce seu trabalho. }\end{array}$ \\
\hline $\begin{array}{l}\text { Outras variáveis } \\
\text { relacionadas }\end{array}$ & $\begin{array}{l}\text { Possibilita ainda, a partir de outra variável disponível (tipo de } \\
\text { ocupação), classificar esse grupo de terceirizados em } \\
\text { Assalariados Contratados em Serviços Terceirizados ou } \\
\text { Autônomos que Trabalham para uma Empresa. }\end{array}$ \\
\hline $\begin{array}{l}\text { Fluxo do } \\
\text { questionário }\end{array}$ & $\begin{array}{l}\text { PNAD Contínua - Pesquisa Nacional por Amostra de } \\
\text { Domicílios Contínua (substituiu a PME) }\end{array}$ \\
\hline Pergunta & Então onde__ exercia normalmente esse trabalho? \\
\hline $\begin{array}{l}\text { Resposta afirmativa } \\
\text { para uma das opções }\end{array}$ & $\begin{array}{l}\text { Se resposta afirmativa para "Em estabelecimento de outro } \\
\text { negócio/empresa" é realizada outra pergunta: "Qual era a } \\
\text { atividade principal desse outro negócio/empresa onde } \\
\text { exercia o trabalho?" }\end{array}$ \\
\hline \multirow{2}{*}{$\begin{array}{l}\text { Outras variáveis } \\
\text { relacionadas }\end{array}$} & $\begin{array}{l}\text { Na semana de _ a _ (semana de referência),__ era } \\
\text { contratado (a) somente por intermediário (empresa } \\
\text { empreiteira, empreiteiro, "gato" etc.)? }\end{array}$ \\
\hline & $\begin{array}{l}\text { Nesse trabalho, } \\
\text { ou de produção, ou, ainda, era membro de associação ou de } \\
\text { grupo de produção? }\end{array}$ \\
\hline
\end{tabular}

Fonte: IBGE e DIEESE, 2016.

Existem ainda dois tipos de registros administrativos do Ministério do Trabalho e Previdência Social (MTPS). A RAIS (Relação Anual de Informações Sociais) é um registro administrativo e tem por objetivo gerar dados para a elaboração de estatísticas do trabalho e de informações do mercado formal de trabalho às entidades governamentais e para a sociedade. O CAGED (Cadastro Geral de Empregados e Desempregados) registra mensalmente as admissões e dispensas de empregados, sob o regime da Consolidação das Leis do Trabalho (CLT). Além da utilização dessas bases para programas como Seguro-Desemprego, elas são também utilizadas na elaboração de estudos e 
pesquisas sobre o mercado de trabalho (MTE, 2016).

Com os dados desses dois bancos (RAIS E CAGED) é possível organizar, através das classificações de atividade econômica (CNAE Classificação Nacional de Atividade Econômica) e de ocupações (CBO Classificação Brasileira de Ocupações), algumas aproximações sobre 0 universo dos trabalhadores terceirizados, como tem sido apresentado em alguns estudos (DIEESE, 2011; ZYBERSTAJN, 2015).

No caso do estudo do DIEESE, foi feito um agrupamento das atividades econômicas entre aquelas de "setores tipicamente terceirizados" e em "setores tipicamente contratantes". Esse agrupamento considerou que a nova CNAE de 2006 foi atualizada para se adequar ao processo de desverticalização que ocorreu nas empresas e setores no Brasil a partir da década de 80 e 90 . No estudo de Zyberstajn, somou-se ao critério de atividade econômica algumas ocupações típicas de trabalhadores terceirizados.

No entanto, essas metodologias utilizadas para calcular a terceirização com a base de dados do MTPS também têm limites. Primeiramente, porque são construídas a partir de aproximações, e configuram-se como estimativas, porque os dados não são diretamente elaborados para captar o fenômeno da terceirização. Em segundo lugar, tratam exclusivamente do mercado formal de trabalho e parte relevante do trabalho terceirizado está presente no mercado informal de trabalho, como sugerem diversos estudos de caso (ALMEIDA, 2008; LIMA, 2009; SILVA, 2014; CORDEIRO, 2015).

As estatísticas nacionais consideram todos os trabalhadores, mas ignoram que a condição de trabalhador terceirizado implica em condições substancialmente distintas daqueles contratados diretamente pela empresa. Sistematizar os indicadores qualitativos a partir da vasta produção acadêmica sobre o tema colabora para ampliar a capacidade de análise do fenômeno e de sua compreensão.

Neste capítulo, elaboramos um mapeamento com parte dessa produção acadêmica, selecionada no Catálogo de Teses e Dissertações da Capes, que tivessem como tema as condições e relações de trabalho dos terceirizados e apresentamos três resultados desse processo: a seleção dos documentos que 
servirão de base para a análise da presente pesquisa; o perfil da produção acadêmica sobre condições e relações de trabalho dos terceirizados; e, por fim, a definição das principais dimensões de análise e os temas (eixos e códigos) a serem utilizados no próximo capítulo.

\subsection{Construindo o universo de pesquisa: os estudos de caso sobre a terceirização}

Outra base de informações disponível para analisar os efeitos da terceirização sobre as condições de trabalho são os estudos qualitativos sobre o tema. Há uma diversidade de estudos, que procuram demonstrar que, para além das justificativas técnicas e de focalização dos negócios, o fator relevante dos processos de terceirização, tanto em processos produtivos como em setores de serviços, é a redução dos custos, proporcionado pela precarização das condições trabalho e salário. Alguns autores são mais conhecidos, mas há uma miríade de trabalhos, entre teses de doutorado e dissertações de mestrado, que não contam com a possibilidade de divulgação eficiente.

Apenas para registrarmos alguns exemplos nesse primeiro momento, os efeitos precarizantes foram notados em muitos estudos em diversos setores de atividade econômica. No setor automotivo brasileiro, que, apesar de fazer uso da terceirização desde sua instalação no Brasil, o processo de terceirização foi levado ao limite nas novas unidades fabris instaladas no país na segunda metade da década de 1990. A fábrica da Volkswagen em Resende, RJ, é um exemplo, com a produção organizada através do "consórcio modular" ${ }^{25}$, e, ali, também foi ampliada a utilização da terceirização nas empresas mais antigas do setor a partir da década de 80 , resultando em precarização do trabalho e também em novas formas de luta por parte do movimento sindical para equalizar direitos (RAMALHO \& RODRIGUES, 2009).

Ainda no setor automotivo, em pesquisa realizada sobre empresa

\footnotetext{
${ }^{25}$ Divisão do processo produtivo em etapas, cada qual sob a responsabilidade de uma empresa distinta no mesmo espaço físico, ficando a responsabilidade pela engenharia, design do produto e as vendas para a Volkswagen (RAMALHO \& RODRIGUES, 2009).
} 
terceirizada na Honda do Brasil, são destacados como consequências da terceirização a fragmentação da representatividade sindical, a precarização dos direitos e o maior controle da empresa tomadora sobre 0 trabalhador terceirizado, entre outros (MARCELINO, 2002).

No setor de confecções, os processos de terceirização tiveram como efeito o aumento do emprego informal, priorizando essa forma de organização produtiva, inclusive através de cooperativas de trabalho. A terceirização tem sido elemento estratégico para redução dos custos com a mão de obra das empresas do setor, precarizando principalmente o trabalho de mulheres, que possuem maior participação na força de trabalho (SILVA, 2009; AMORIM, 2003).

No segmento de teleatendimento, a precarização pode ser caracterizada pelo patamar de remuneração reduzido e variável a partir do cumprimento de metas de atendimento, pela alta rotatividade, pela arbitrariedade no exercício do poder empregatício, com altos índices de adoecimento profissional, entre outros, e com características próprias do perfil desses trabalhadores: jovens e mulheres não brancas com baixa qualificação (BRAGA, 2014).

No setor elétrico, a taxa de mortalidade é 3,21 vezes superior entre os trabalhadores terceirizados, quando comparada com o quadro próprio de funcionários (DIEESE, 2010).

Os estudos de caso sobre terceirização têm a relevante capacidade de problematizar o tema e apresentar conclusões sobre esse fenômeno e seus impactos, auxiliando no entendimento de suas características e seus efeitos sobre o mercado e o processo de trabalho, mas, também sobre as relações mais gerais desse processo no local de trabalho com o padrão de acumulação capitalista atual. Entretanto, esses estudos estão dispersos e sua capacidade individual de generalização, por questões de ordem epistemológica e metodológica, é bastante baixa. O que faz sua força é o conjunto.

Esses estudos são uma espécie de lente de aumento e buscam analisar em profundidade uma determinada situação, destacando suas singularidades (BEAUD; PIALOUX, 2009). Por esse motivo, buscaremos realizar um balanço dessa produção e utilizá-lo como base para a construção de indicadores de 
precarização das condições e relações de trabalho entre os terceirizados.

Sabemos que o material-base de nossa pesquisa, formado por estudos de caso, ou estudos monográficos, ou ainda por aqueles de caráter etnográficos são permeados pelas escolhas dos autores, tanto metodológicas como teóricas, quanto de definição do escopo da pesquisa. No entanto, como observa Druck (2011), as estatísticas também são permeadas por essas questões, porque suas informações são construídas, resultado de observação, de fatos e de um trabalho de conceituação e não apenas uma operação de medida.

\subsection{Metodologia utilizada para seleção dos documentos}

Para nosso estudo de base documental escolhemos utilizar as teses e dissertações e realizar a busca desse material no Catálogo de Teses e Dissertações da Capes, devido à sua abrangência nacional, que possibilita recortes regionais e setoriais. Não utilizaremos artigos acadêmicos, porque em muitos casos, a produção das teses e dissertações está também divulgada nas diversas revistas acadêmicas e com isso, poderíamos incorrer no erro de duplicar as informações. Nas teses e dissertações, as informações estão apresentadas de forma mais detalhada.

Nossa leitura dessa base documental deve levar em consideração a lógica de organização desses arquivos; de ter claro por quais descritores o documento será procurado (nome de pessoas, datas, temas, objeto); a quem se destinava e quem era o autor; da localização do texto e da análise de sua credibilidade e pertinência e ainda da possibilidade de deformação dos elementos disponíveis no seu relato, constituindo, assim, um conjunto documental que possibilita a realização da pesquisa e da consolidação de respostas às nossas hipóteses, mas que também deve considerar seus limites (CELLARD, 2008).

As teses e dissertações apresentam os dados, considerações e análises de forma mais detalhada do que em periódicos especializados, além de possuir um formato/estrutura mais homogêneo, que pode auxiliar no levantamento e 
sistematização de informações para a nossa análise. Conforme as Diretrizes de apresentação de teses e dissertações da USP, a definição desses documentos é:

$\S 1^{\circ}$ - Considera-se dissertação de Mestrado o texto resultante de trabalho supervisionado, que demonstre capacidade de sistematização crítica do conhecimento acumulado sobre o tema tratado e de utilização de métodos e técnicas de investigação científica, tecnológica ou artística, visando desenvolvimento acadêmico ou profissional, de acordo com a natureza da área e os objetivos do curso.

$\S 2^{\circ}$ - Considera-se tese de Doutorado o texto resultante de trabalho supervisionado de investigação científica, tecnológica ou artística que represente contribuição original em pesquisa e inovação, visando desenvolvimento acadêmico ou profissional, de acordo com a natureza da área e os objetivos do curso (USP, 2016, p. 23).

Segundo LOPES e ROMANCINI (2006), as teses e dissertações como base documental de uma pesquisa podem ser utilizadas de diversas perspectivas: analisar uma problemática específica de um campo de conhecimento, um período determinado da produção acadêmica ou a trajetória de uma área escolhida. As teses e dissertações consolidam um acervo científico importante, em que são apresentadas as preocupações dos cientistas, questões relevantes para suas disciplinas, teorias, metodologias, explicação de fenômenos daquela área. O resultado do trabalho é avaliado e julgado a partir do estado do conhecimento daquele campo, portanto, essa produção dispõe de elementos importantes para a análise que buscamos realizar em nossa pesquisa.

Essa produção acadêmica - teses e dissertações - até pouco tempo era considerada uma literatura cinzenta, ou seja, "(...) aquela que se caracteriza de difícil acesso e aquisição, sem ter passado, ou estar regida, por qualquer tipo de controle bibliográfico específico" (FUNARO, NORONHA, 2006, p. 218); ou ainda "(...) documentos fugitivos, que não se vendem nos catálogos de editores, livrarias, bibliotecas, etc., de difícil localização e que, na maioria dos casos, contém dados relevantes e importantes" (Poblaciónet al, 1992, apud FUNARO e NORONHA, 2006, p. 220), e, por fim, aquela que é “(...) produzida 
em todos os níveis de governo, acadêmico e industrial, em formato impresso ou eletrônico, mas que não é contratada por editores comerciais". (Almeida, 20002, apud FUNARO e NORONHA, 2006, p. 220).

De modo geral, apesar de algumas diferenças nessas definições, a literatura cinzenta é aquela literatura de difícil acesso e de pouca visibilidade, seja pela sua tipologia (teses, dissertações, eventos acadêmicos) ou pelas suas características (difícil acesso, tiragem limitada, linguagem acadêmica etc.). Segundo esses autores, as teses e dissertações podem ser de acesso restrito devido ao fato de que a maior parte desses documentos está disponível apenas em formato impresso em uma única biblioteca - a de origem do programa de pós-graduação onde foi apresentado.

Essa literatura considerada cinzenta ganha maior visibilidade com o advento de novas tecnologias digitais e com a elaboração de bases de dados dos acervos das universidades e suas bibliotecas. Nosso trabalho se ancora nesse processo e se beneficia dele. Esse movimento é bastante relevante porque a ciência é um empreendimento coletivo e a garantia dessa visibilidade é uma qualidade essencial (PACKER \& MENEGHINI, 2006). As novas tecnologias, tanto de organização das informações como de disponibilização dos dados via web, mudaram bastante a forma de controle bibliográfico e as informações disponíveis, inclusive com acesso remoto aos documentos completos.

No Brasil, cada vez mais os catálogos eletrônicos procuram garantir o acesso aos resumos ou aos textos completos em portais específicos das bibliotecas das universidades e também nos bancos de dados nacionais, que integram a produção acadêmica brasileira em uma única base de dados ou em uma única base de pesquisa/busca. Esse movimento ainda carece de certa padronização, de ferramentas mais "amigáveis" de busca e de incluir parte considerável do acervo que ainda está mergulhado na neblina cinzenta, mas os avanços que estão se consolidando ao longo dos últimos 15 anos é o que permite uma análise como a que estamos propondo, de sistematizar uma grande seleção de estudos sobre determinado tema, apresentado em diversas instituições de ensino no território nacional.

Como dito no parágrafo anterior, é recente na produção acadêmica 
brasileira de teses e dissertações os catálogos eletrônicos nacionais da produção acadêmica brasileira via web, e ainda mais recente a disponibilidade dos resumos ou arquivos completos. A Biblioteca Digital Brasileira de Teses e Dissertações (BDTD) foi inaugurada em 2002, e procura “(...) integrar e disseminar os textos completos das teses e dissertações defendidas nas instituições brasileiras de ensino e pesquisa", e "(...) contribui para dar maior visibilidade à produção científica nacional e à difusão de informações de interesse científico e tecnológico para a sociedade em gerap"26.

Apesar do lançamento em 2002, essa base passou por diversas revisões ao longo desses anos para garantir acesso ao maior número de produções, inclusive para aquelas universidades que não dispunham de repositórios para sua produção acadêmica. Apenas para relatar algumas inovações, em 2012 teve início um processo de revisão do Padrão Brasileiro de Metadados para Descrição de Teses e Dissertações (BDTD) e, em 2014, foi lançado o novo Sistema da BDTD (Portal e coletor) e o novo Sistema de Publicação Eletrônica de Teses e Dissertações (TEDE). É um processo contínuo que vem melhorando a captação de documentos e a oferta de informações.

Em nossa pesquisa, o BDTD foi um instrumento de coleta auxiliar após a seleção dos documentos através do Catálogo de Teses e Dissertações da Capes. O BDTD disponibiliza apenas os registros de documentos completos, enquanto a Capes disponibiliza o catálogo de toda a produção, inclusive daqueles cujos documentos completos não estão disponíveis em meio eletrônico.

O Catálogo de teses e dissertações da Capes foi colocado à disposição em meio eletrônico a partir de 2002, mas somente em março de 2006 o Ministério da Educação (MEC) tornou obrigatória a entrega das teses e dissertações em formato físico e eletrônico. A Portaria oo 013 de 15/02/2006 (MEC/Capes) tornou obrigatório o envio desses documentos pelos programas de pós-graduação para a Capes, a "(...) produção científica discente é um

\footnotetext{
${ }^{26}$ Disponível em: <http://bdtd.ibict.br/vufind/Content/whatls> $>$. Acesso em: 30 jan. 2018.
} 
relevante indicador da qualidade dos programas de mestrado e doutorado, não aferível apenas através da publicação seletiva nos periódicos especializados".

O objetivo do Catálogo da Capes é dar visibilidade a essa produção e utilizar as informações como um indicador para avaliação da produção acadêmica brasileira. Segundo a Capes, seu catálogo reunia o registro de 458.657 teses e dissertações ${ }^{27}$, defendidas em todo o país desde 1987 até 2016. Com informações bibliográficas, permite a pesquisa por autor, título e palavras-chave. As informações desse catálogo são fornecidas diretamente pelos programas de pós-graduação.

Como complemento ao Catálogo de teses e dissertações da Capes, a Plataforma Sucupira/Capes foi inaugurada em 2014 para ser a base de referência do Sistema Nacional de Pós-Graduação (SNPG), através da coleta e sistematização das informações e resultando em análises e avaliações. Nessa plataforma, entre os diversos dados disponíveis relativos à pós-graduação no Brasil, é possível acessar a ficha catalográfica padronizada das teses e dissertações, o que inclui os resumos, e, para alguns registros, a tese ou dissertação completa.

Dessa forma, os dois bancos se completam: quando o registro disponível no Catalogo da Capes foi realizado ou atualizado depois de 2014, há um link ("Detalhes") que leva à Plataforma Sucupira, através da qual podemos ter acesso às demais informações (Figura 1, página 56).

\footnotetext{
${ }^{27}$ Disponível em: <ihttp://www.capes.gov.br/36-noticias/3316-banco-de-teses-da-capes-possuimais-de-450-mil-resumos>Acesso em: 01 jun. 2017.
} 
FIGURA 1 - llustração da tela de acesso ao Catálogo de teses e dissertações da Capes e Plataforma sucupira, 2018

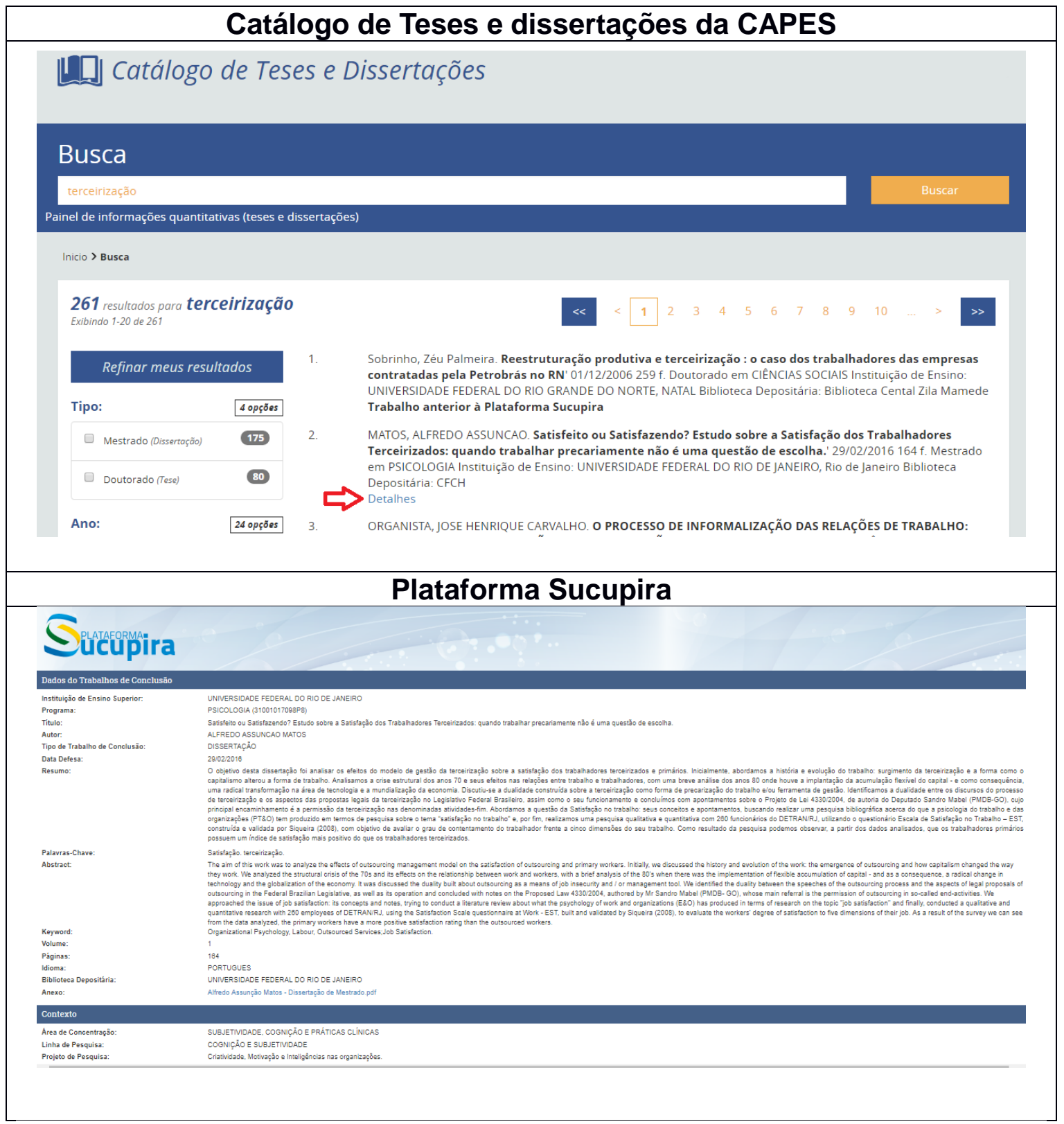

Fonte: http://catalogodeteses.capes.gov.br/catalogo-teses/\#!/ e

https://sucupira.capes.gov.br/sucupira/public/consultas/coleta/trabalhoConclusao/viewTrabalho Conclusao.jsf?popup=true\&id trabalho=3070837, 2018.

Para a pesquisa realizada no Banco de Teses e Dissertação da Capes foi utilizado o termo Terceirização, que resultou em 1.323 publicações $^{28}$. Esse número expressivo de estudos sobre o tema demonstra sua relevância como fenômeno social na atualidade, mas também impõe uma dificuldade para

28 Pesquisa realizada em 01 de junho de 2017. Disponível em: $<$ http://bancodeteses.Capes.gov.br/banco-teses/\#!!>. Acesso em: 01 jun. 2017. 
realizar uma seleção que garanta um painel representativo do tema. Assim, precisamos estabelecer um recorte de pesquisa factível para um mestrado.

Nosso foco está nos efeitos da terceirização nas condições e relações de trabalho e, por esse motivo, nossa primeira seleção voltou-se para os documentos disponíveis na Grande área de conhecimento definida pelo banco de dados como Ciências Humanas ${ }^{29}$, que agrega $235^{30}$ publicações no banco de dados. As informações disponíveis no Catálogo são: nome do autor da tese ou dissertação, título da tese ou dissertação, data de defesa, número de páginas, titulação adquirida, área do programa de pós-graduação, universidade ao qual o programa pertence, cidade onde o programa está localizado, biblioteca onde a tese ou dissertação está disponível. Em parte desses documentos estava disponível a ficha catalográfica na Plataforma Sucupira, da qual utilizamos os resumos das teses e dissertações. As fichas catalográficas dessa plataforma colocam à disposição o resumo da pesquisa, as palavraschave, o idioma, a linha de pesquisa e o nome do projeto de pesquisa original, a banca examinadora, tipo de vínculo empregatício do autor da pesquisa, tipo de instituição, expectativa de atuação e área de atuação.

As Teses e Dissertações que foram defendidas anteriormente à Plataforma Sucupira não possuem a ficha catalográfica e, portanto, os resumos foram coletados nas fichas catalográficas dos repositórios ou bibliotecas virtuais das universidades pertinentes diretamente ou com o auxílio da BDTD. Quando as bibliotecas ou repositórios não tinham à disposição o resumo, os dados foram coletados diretamente nos textos completos das Teses ou Dissertações. Por fim, em cinco documentos o resumo foi encontrado em artigos apresentados em congressos acadêmicos (Tabela 1, página 58).

\footnotetext{
${ }^{29}$ As demais áreas de conhecimento são: ciências agrárias, ciências da saúde, ciências exatas e da terra, ciências sociais aplicadas, engenharias, linguística, letras e artes, multidisciplinar.

${ }^{30}$ A busca resultou em 236 fichas catalográficas, no entanto, uma delas se tratava de um registro duplicado, a dissertação de mestrado de Alex Almeida Coêlho.
} 
TABELA 1 - Local de coleta dos resumos das teses e dissertações analisadas

\begin{tabular}{lc}
\hline \multicolumn{1}{c}{ Local de coleta do Resumo } & Número de documentos \\
\hline Capes/Sucupira & 94 \\
\hline Teses ou dissertações - texto completo & 98 \\
\hline Biblioteca digital; repositórios institucionais & 28 \\
\hline Artigo apresentado em congresso & 5 \\
\hline Falta encontrar resumo para classificação & 10 \\
\hline \multicolumn{2}{c}{ Total } \\
\hline
\end{tabular}

Fontes: resultados da pesquisa. Elaboração própria.

É relevante destacar que apesar dos avanços no registro da produção acadêmica, das teses, dissertações e artigos científicos, entre outros, a visibilidade de parte da produção ainda tem limites, em especial, no caso das Teses e Dissertações anteriores aos anos 2000. Mesmo após diversas buscas com ferramentas distintas nos bancos de dados de teses e dissertações nacionais e das universidades, não foi possível encontrar $10^{31}$ resumos que não estão disponíveis em meio eletrônico ou em bibliotecas físicas próximas de onde se executa a pesquisa, a cidade de São Paulo ${ }^{32}$.

O recurso de pesquisa bibliográfica a partir de dados catalográficos da produção acadêmica como fonte documental é uma estratégia relevante para o mapeamento de determinado tema em diferentes campos do conhecimento. Essa metodologia pode auxiliar na definição de critérios de seleção frente a uma vasta produção, como a que temos no caso dos estudos sobre terceirização. Os catálogos permitem o rastreamento da produção já elaborada, auxiliam na orientação da leitura, fornecem informações básicas sobre as pesquisas como local, data de defesa, área de conhecimento em que foi apresentada a pesquisa.

Essa fonte documental também apresenta os títulos que expressam

\footnotetext{
${ }^{31}$ Em 21/05/2018, a Biblioteca Florestan Fernandes/FFLCH/USP, ao qual o PPGS/USP está ligado, ainda não havia obtido sucesso em nenhuma das 10 solicitações realizadas através do sistema de Comut. O serviço de Comut permite a obtenção de cópias de documentos disponíveis nos acervos das principais bibliotecas brasileiras.

${ }^{32}$ Diversas estratégias foram utilizadas aqui: além das buscas nas bibliotecas digitais, nos repositórios, na BDTD (Biblioteca Digital de Teses e Dissertações), contato com o autor no Currículo Lattes ou ainda pesquisa em buscadores. Esses 10 documentos foram solicitados para as bibliotecas onde estão depositadas as cópias físicas das Teses e Dissertações, mas por motivos distintos, não foi possível conseguir uma cópia (Anexo 1).
} 
informações relevantes sobre o trabalho ou indicam elementos que caracterizam seu conteúdo, e os resumos que divulgam informações sobre objetivo principal de investigação, sobre a metodologia ou procedimentos utilizados na abordagem do problema proposto, os instrumentos teóricos, as técnicas, os sujeitos e os métodos para o tratamento dos dados, além das conclusões de forma mais concisa. $\mathrm{O}$ uso dessa fonte documental possibilita uma primeira interação dessa produção que se pretende analisar e favorece o esforço de ordenação (FERREIRA, 2002).

Segundo Ferreira (2002), os resumos como item das dissertações e teses eram pouco comuns na produção acadêmica da década de 1970 e na primeira metade da década de 1980 (em nossa pesquisa encontramos documentos da década de 90 que também não possuíam o resumo). Nesses casos, não está disponível o resumo na ficha catalográfica ou, ainda, elas podem ter sido escritas pelos organizadores dos bancos de dados. Nas produções mais recentes, há casos também em que os resumos apresentados pelos autores em suas teses e dissertações são reescritos pelos organizadores dos bancos de dados bibliográficos, buscando homogeneizar as informações disponíveis.

Ainda sobre os resumos, Ferreira comenta que é possível também que o próprio autor escreva diferentes resumos, um para o seu documento, outro para o catálogo do programa e outro ainda para a Capes/Sucupira, que podem solicitar conteúdos distintos. Mesmo os resumos escritos pelos autores têm diferenças entre si: mais longos, mais curtos, que retratam uma seleção dos elementos da pesquisa (objeto, hipótese, metodologia, resultados) e outros que constroem uma narrativa do percurso realizado. Segundo a autora:

(...) os resumos mostram uma rede de motivos implicada em operações de selecionar e organizar o material a ser divulgado, que os tornam diversificados e multifacetados, resultados de diferentes operações (cortes e acréscimos) feitas a muitas mãos, por diferentes motivos totalmente desconhecidos do autor (FERREIRA, 2002, p. 263)

Portanto, apesar da aparente homogeneidade, há, na verdade, uma relevante heterogeneidade que pode interferir na análise final dessa base documental. Em nosso mapeamento, por exemplo, inicialmente iríamos 
sistematizar também as informações sobre tipo de pesquisa (teórica, empírica, documental, comparada, estudo de caso) e também as escolhas de abordagens teóricas e hipóteses, no entanto, considerando a grande diversidade de estrutura dos resumos e a falta de informações suficientes sobre esses campos nos resumos, esses conteúdos ficaram de fora do mapeamento e mas se não fossem esses limites, poderiam ter sido considerados e auxiliado na seleção dos documentos que compõe o escopo da pesquisa.

Apesar das limitações desse material, os resumos apresentam o conteúdo temático das pesquisas, seus principais aspectos, o objeto de pesquisa e os objetivos, em uma linguagem concisa e descritiva (Ferreira, 2002), elementos que são adequados para nossas pretensões.

Feitas essas considerações, as informações disponíveis no banco de teses e dissertações da Capes e na Plataforma Sucupira permitiram elaborar um perfil das 235 publicações da Grande área de conhecimento Ciências Humanas com os dados das fichas catalográficas e classificá-las utilizando os títulos e os resumos. Foram sistematizadas informações sobre a produção acadêmica propriamente dita, com informações sobre as universidades, áreas de pesquisa, estados da Federação onde as teses e dissertações foram realizadas.

Outro grupo de informações sistematizado a partir dos resumos inclui informações sobre os objetos investigados (buscando aqueles que destacam os trabalhadores terceirizados, as diferenças entre trabalhadores diretos e terceirizados, os trabalhadores em formas precárias de trabalho que camuflam ou se sobrepõem à relação de terceirizado e também aquelas que investigam a ação coletiva e sindical) e o objetivo do estudo (buscando os estudos que analisam os impactos do processo de terceirização para as condições e relações de trabalho). Também destacamos informações sobre os setores de atividade econômica e as empresas estudadas, além do levantamento de temas que irão nos orientar na elaboração dos indicadores de precarização das condições e relações de trabalho dos terceirizados, conforme detalhado no Quadro 3, abaixo.

As informações sistematizadas estão organizadas em um arquivo em 
formato "Banco de Dados" (Anexo II, página 222), no qual as colunas são os itens da coluna "campos", conforme quadro abaixo, e a informação de cada tese ou dissertação corresponde a uma linha.

QUADRO 3 - Campos utilizados para a construção do mapeamento da produção acadêmica sobre condições e relações de trabalho entre os terceirizados

\begin{tabular}{|c|c|c|c|}
\hline Campos & Coluna & Conteúdo & Fonte \\
\hline NÚMERO & 1 & $\begin{array}{l}\text { Número de classificação do } \\
\text { documento no painel, } \\
\text { definido pela pesquisadora }\end{array}$ & $\begin{array}{l}\text { Estabelecida pela } \\
\text { pesquisadora }\end{array}$ \\
\hline GRUPO & 2 & $\begin{array}{l}\text { Classificação da Tese ou } \\
\text { dissertação quanto ao } \\
\text { conteúdo: Terceirização e } \\
\text { efeitos para as condições e } \\
\text { relações de trabalho. }\end{array}$ & Estipulado pela autora. \\
\hline NOME & 3 & Nome do autor & Capes \\
\hline $\mathrm{H} / \mathrm{M}$ & 4 & Sexo autor & $\begin{array}{l}\text { Estipulado pela } \\
\text { pesquisadora pelo } \\
\text { nome do autor }\end{array}$ \\
\hline TÍTULO & 5 & Título completo & Capes \\
\hline DADA DE DEFESA & 6 & Data de defesa & Capes \\
\hline № DE PAG. & 7 & Número de páginas & Capes \\
\hline TITULAÇÃO & 8 & Doutorado ou mestrado & Capes \\
\hline ÁREA & 9 & $\begin{array}{l}\text { Área do programa de pós- } \\
\text { graduação }\end{array}$ & Capes \\
\hline UNIVERSIDADE & 10 & $\begin{array}{l}\text { Universidade onde realizou } \\
\text { a pós-graduação }\end{array}$ & Capes \\
\hline CIDADE & 11 & $\begin{array}{c}\text { Cidade onde realizou a pós- } \\
\text { graduação }\end{array}$ & Capes \\
\hline UF & 12 & $\begin{array}{c}\text { Estado onde realizou a pós- } \\
\text { graduação }\end{array}$ & Capes \\
\hline BIBLIOTECA & 13 & $\begin{array}{c}\text { Biblioteca onde está } \\
\text { depositado o documento }\end{array}$ & Capes \\
\hline
\end{tabular}




\begin{tabular}{|c|c|c|c|}
\hline Campos & Coluna & Conteúdo & Fonte \\
\hline $\begin{array}{c}\text { DOCUMENTO } \\
\text { PARA } \\
\text { PREENCHIMENTO }\end{array}$ & 14 & $\begin{array}{l}\text { Documento disponível para } \\
\text { análise do resumo }\end{array}$ & $\begin{array}{c}\text { Capes, fichas } \\
\text { catalográficas das } \\
\text { bibliotecas ou dos } \\
\text { repositórios } \\
\text { institucionais, resumo } \\
\text { de artigos }\end{array}$ \\
\hline $\begin{array}{l}\text { OBJETO } \\
\text { INVESTIGADO }\end{array}$ & 15 & $\begin{array}{c}\text { Destacara o tema principal } \\
\text { da pesquisa através do título } \\
\text { e do resumo }\end{array}$ & $\begin{array}{c}\text { Capes/Sucupira, fichas } \\
\text { catalográficas das } \\
\text { bibliotecas ou dos } \\
\text { repositórios } \\
\text { institucionais, resumo } \\
\text { de artigos }\end{array}$ \\
\hline $\begin{array}{l}\text { OBJETIVO } \\
\text { INVESTIGADO }\end{array}$ & 16 & $\begin{array}{c}\text { Destacar os objetivos da } \\
\text { pesquisa através do título e } \\
\text { do resumo }\end{array}$ & $\begin{array}{c}\text { Capes/Sucupira, fichas } \\
\text { catalográficas das } \\
\text { bibliotecas ou dos } \\
\text { repositórios } \\
\text { institucionais, resumo } \\
\text { de artigos }\end{array}$ \\
\hline $\begin{array}{l}\text { TIPO DE } \\
\text { PESQUISA* }\end{array}$ & 17 & $\begin{array}{l}\text { Tipos: Teórica, } \\
\text { metodológica, Empírica, } \\
\text { Aplicada, Documental }\end{array}$ & $\begin{array}{c}\text { Capes/Sucupira, fichas } \\
\text { catalográficas das } \\
\text { bibliotecas ou dos } \\
\text { repositórios } \\
\text { institucionais, resumo } \\
\text { de artigos }\end{array}$ \\
\hline $\begin{array}{c}\text { TEORIAS/AUTORE } \\
\mathrm{S}^{*}\end{array}$ & 18 & $\begin{array}{c}\text { Destacar teorias, conceitos e } \\
\text { autores utilizados na } \\
\text { pesquisa }\end{array}$ & $\begin{array}{c}\text { Capes/Sucupira, fichas } \\
\text { catalográficas das } \\
\text { bibliotecas ou dos } \\
\text { repositórios } \\
\text { institucionais, resumo } \\
\text { de artigos }\end{array}$ \\
\hline $\begin{array}{l}\text { SETORES DE } \\
\text { ATIVIDADE } \\
\text { ECONÔMICA }\end{array}$ & 19 & $\begin{array}{l}\text { Buscar setor e/ou empresa } \\
\text { estudada (aproximação da } \\
\text { CNAE 2.0) }\end{array}$ & $\begin{array}{c}\text { Capes/Sucupira, fichas } \\
\text { catalográficas das } \\
\text { bibliotecas ou dos } \\
\text { repositórios } \\
\text { institucionais, resumo } \\
\text { de artigos }\end{array}$ \\
\hline EMPRESA & 20 & Empresa(s) estudada(s) & $\begin{array}{l}\text { Capes/Sucupira, fichas } \\
\text { catalográficas das } \\
\text { bibliotecas ou dos } \\
\text { repositórios } \\
\text { institucionais, resumo } \\
\text { de artigos }\end{array}$ \\
\hline $\begin{array}{l}\text { CIDADE BASE DA } \\
\text { PESQUISA }\end{array}$ & 21 & $\begin{array}{c}\text { Cidade ou região do objeto } \\
\text { de estudo }\end{array}$ & $\begin{array}{l}\text { Capes/Sucupira, fichas } \\
\text { catalográficas das } \\
\text { bibliotecas ou dos }\end{array}$ \\
\hline
\end{tabular}




\begin{tabular}{|c|c|c|c|}
\hline Campos & Coluna & Conteúdo & Fonte \\
\hline & & & $\begin{array}{c}\text { repositórios } \\
\text { institucionais, resumo } \\
\text { de artigos }\end{array}$ \\
\hline $\begin{array}{l}\text { UF BASE DA } \\
\text { PESQUISA }\end{array}$ & 22 & $\begin{array}{c}\text { Estado e/ ou país do objeto } \\
\text { de estudo }\end{array}$ & $\begin{array}{l}\text { Capes/Sucupira, fichas } \\
\text { catalográficas das } \\
\text { bibliotecas ou dos } \\
\text { repositórios } \\
\text { institucionais, resumo } \\
\text { de artigos }\end{array}$ \\
\hline INDICADORES & 23 & $\begin{array}{l}\text { Lista de temas tratados que } \\
\text { podem contribuir para o } \\
\text { conteúdo dos indicadores de } \\
\text { precarização das condições } \\
\text { e relações de trabalho }\end{array}$ & $\begin{array}{l}\text { Capes/Sucupira, fichas } \\
\text { catalográficas das } \\
\text { bibliotecas ou dos } \\
\text { repositórios } \\
\text { institucionais, resumo } \\
\text { de artigos }\end{array}$ \\
\hline
\end{tabular}

Fontes: resultados da pesquisa. Elaboração própria.

No mapeamento, devido a essa heterogeneidade na construção dos resumos, como apontado acima, alguns documentos não apresentavam todas as informações que procuramos sistematizar. Nesse caso, em nosso quadro, a célula foi preenchida com a informação "ND" (Não Disponível). Quando a pesquisa não possuía informação para algum campo, devido ao objeto e objetivos próprios do estudo, a célula foi preenchida com a informação "NSA" (Não se aplica).

A partir da sistematização de informações bibliográficas das 235 Teses e Dissertações, classificamos as publicações disponíveis em três grupos:

- Grupo 1 (114 documentos): Teses e Dissertações tratando da terceirização e seus efeitos nas relações e condições de trabalho, que apresentam informações sobre o perfil dos trabalhadores nas atividades terceirizadas, que trazem informações, dados e análises e que também apresentam análises comparativas entre os trabalhadores diretamente contratados e os trabalhadores terceirizados. Nesse grupo, também estão inseridos aqueles documentos que estudam formas de trabalho precárias relacionadas à terceirização, como trabalho a domicílio, trabalho informal e trabalho em cooperativas; 
- Grupo 2 (37 documentos): Teses e Dissertações que tratam da terceirização, mas seu objeto de pesquisa são os efeitos desse processo para o território, para a reconfiguração de setores de atividade econômica, ou sobre a prestação do serviço terceirizado, tanto na iniciativa privada como no setor público e que, portanto, não têm como foco as relações de trabalho;

- Grupo 3 (74 documentos): Teses e dissertações que trazem o termo da terceirização mas fora do escopo definido na pesquisa, mas em outro contexto, ou seja, não estudam os processos de terceirização de partes do processo produtivo ou de serviços e seus impactos. Também estão incluídas Teses e Dissertações que tratam das condições e relações de trabalho, mas não em processos de terceirização, ou ainda, tratam de modo mais geral, dos impactos da Reestruturação produtiva, sem destacar especificamente quais os impactos da terceirização nesse processo. Nesse caso, também estão teses e dissertações que possivelmente foram classificadas de forma equivocada com o termo terceirização.

A partir dessa classificação, o mapeamento que apresentaremos a seguir irá se concentrar no primeiro grupo - que possui o conteúdo que nos interessa para o balanço das teses e dissertações e para a construção dos indicadores de precarização das condições e relações de trabalho entre os terceirizados. O segundo grupo poderá ser consultado, em especial, aqueles que, mesmo não se concentrando nas condições e relações de trabalho, apresentam alguma reflexão ou informação sobre o recorte proposto para nossa análise. O terceiro grupo foi descartado da pesquisa.

Antes de seguir para a próxima sessão, apresentaremos de modo sucinto algumas características do Grupo 2 e 3, para garantir o registro da pesquisa.

O acima chamado Grupo 2, que não foi incluído no mapeamento, é composto por teses e dissertações que tratam da terceirização, mas o seu conteúdo está fora do escopo definido na pesquisa. Nesse caso, encontram-se treze documentos que tratam da terceirização como processo de privatização do Estado, das políticas e dos serviços públicos, não estudam, portanto, os 
efeitos para os trabalhadores. Nesse grupo, sete documentos estudam os processos de terceirização e os efeitos na dimensão territorial. Outras cinco pesquisas tem como objeto de estudo os processos de reestruturação produtiva, mas não há uma análise específica sobre os efeitos da terceirização, ela está inserida nesse processo mais amplo. Três estudos investigam a terceirização em seus aspectos jurídicos. Outros estudos investigam temas variados da psicologia à fotografia, onde tangencialmente, a terceirização é abordada, mas que também não apresentam os efeitos para os trabalhadores.

Eles estão distribuídos da seguinte forma, por área de conhecimento: oito em Educação e oito em Geografia; sete em Ciência Política; cinco em Sociologia; quatro em psicologia; e dois em outras áreas (relações internacionais e políticas públicas). Há apenas um estudo na década de 90. 0 restante está distribuído ao longo dos anos 2000 a 2016.

Em relação ao Grupo 3, os principais objetos de pesquisa são relacionados a educação (formação profissional e políticas educacionais). $\mathrm{Na}$ sequência temos um grupo de estudos que trata das condições de trabalho, mas que não apresenta os efeitos da terceirização de forma separada. Além desses dois grupos, há uma variação bastante grande de temas, como adolescentes em conflito com a Lei, gestão de resíduos sólidos, saúde mental, microcrédito, entre outros. Considerando as áreas de conhecimento, os documentos estão distribuídos da seguinte forma: trinta e um em Educação; nove em Psicologia; sete em Geografia; quatro em Sociologia; três em Ciências Sociais; dois em Antropologia; um em Ciência Política e um em Estudos Estratégicos. Em relação à periodicidade, três foram defendidos na década de 90; vinte e um foram defendidos nos anos 2000; e trinta e cinco foram depositados em seus programas de pós-graduação entre 2010 a 2016.

\subsection{Perfil dos estudos sobre condições e relações de trabalho dos terceirizados no Brasil}


Entre os estudos selecionados e que já foram objeto de sistematização conforme metodologia apresentada na seção anterior, o Grupo 1 - Teses e Dissertações sobre condições e relações de trabalho dos terceirizados é composto por 114 documentos, sendo 33 teses (28,9\%), 79 dissertações de mestrado $(69,3 \%)$ e duas dissertações de mestrado profissional $(1,8 \%)$.

Essas teses e dissertações estão distribuídas em um período que vai de 1995 a 2016, contemplando um período importante da difusão da terceirização no Brasil (Gráfico 1, página 66). É possível observar que há uma concentração maior desses estudos a partir dos anos 2000, em especial, nos últimos dois anos aqui analisados $\left(2015\right.$ e 2016) ${ }^{33}$. Esse aumento no último período pode estar relacionado à ampliação do debate sobre a regulamentação da terceirização no Brasil e a consequente discussão sobre esse tema em diversos espaços, inclusive nas universidades.

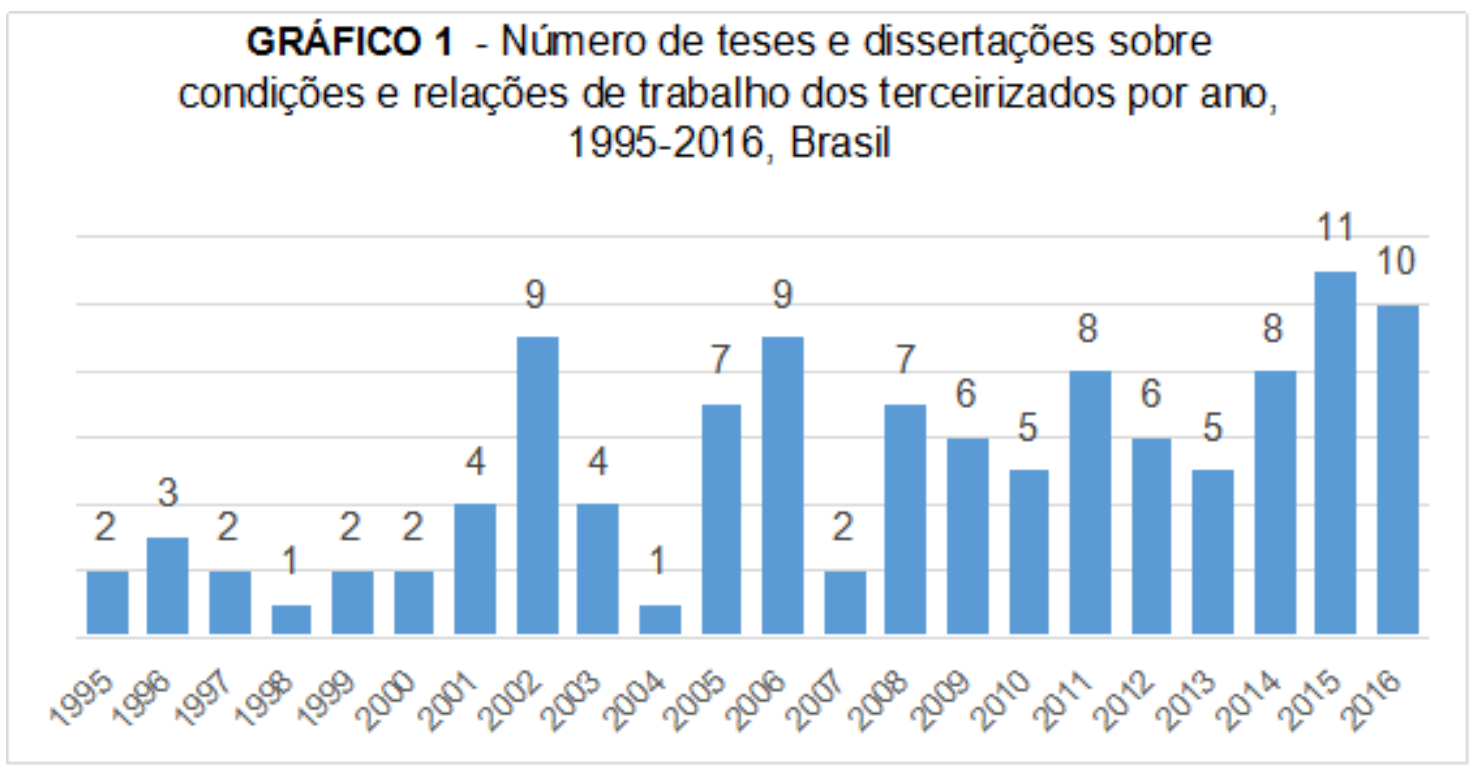

Fonte: Banco de Teses e dissertações da Capes. Elaboração própria.

Entre os estudos selecionados no Grupo 1, destacam-se entre os autores 58 documentos escritos por mulheres e 45 documentos escritos por homens (Tabela 2, página 67). Como analisa Krein e Castro (2017), os “(...)

\footnotetext{
${ }^{33}$ Mesmo que os 10 estudos que ainda não foram sistematizados fossem incorporados nesse Grupo, essa distribuição se manteria. Ano de defesa dos documentos não encontrados: 1995 (1); 1996 (1); 1997 (1); 2001 (3); 2005 (2); 2007 (2).
} 
estudos com recorte de gênero indicam que a terceirização expressa mais uma vez uma diferenciação entre homens e mulheres, reafirmando a condição de inserção mais precária das mulheres no mercado de trabalho." (p. 120) e indicam que há uma participação maior de mulheres trabalhando em empresas terceiras em setores como alimentação, confecção, educação e saúde e atividades financeiras, em que a participação das mulheres ultrapassa os $60 \%$.

\section{É bastante relevante que a maior parte dos autores sobre essa} temática seja composta justamente por mulheres, e que trazem para a análise a perspectiva das trabalhadoras terceirizadas. Como poderemos observar mais à frente nessa pesquisa, há uma grande frequência de documentos que analisam o trabalho feminino e a terceirização.

TABELA 2 - Distribuição dos autores e autoras das Teses e Dissertações sobre condições e relações de trabalho dos terceirizados por sexo, 1995 a 2016, Brasil

\begin{tabular}{lcc}
\hline Sexo & Total & $\%$ \\
\hline Homens & 45 & 39,5 \\
\hline Mulheres & 58 & 50,9 \\
\hline Não disponível & 11 & 9,6 \\
\hline Total & 114 & 100,0 \\
\hline
\end{tabular}

Fonte: Banco de Teses e Dissertações da CAPES. Elaboração própria, 2018.

Quanto aos programas de Pós-Graduação para os quais foram apresentadas as Teses e Dissertações aqui analisadas, a maior parte se concentra em Ciências Sociais (28,8\%), Sociologia (27\%), Geografia (10,8\%) Educação (9,9\%) e Psicologia (9,9\%) (Tabela 3, página 68). Esses programas representam pouco mais de $86 \%$ do total de documentos analisados e trazem aspectos diversificados sobre condições e relações de trabalho dos terceirizados, segundo a perspectiva analítica de cada campo de conhecimento, como formação profissional em Educação ou identidade dos trabalhadores nas áreas de Psicologia, conforme apresentaremos no próximo item.

Os programas com maior frequência (Ciências Sociais, Sociologia e Geografia) também são aqueles que desde o começo aparecem com maior 
participação no número de estudos analisados. No período de 1995 a 1999, são essas as únicas áreas com estudos presentes em nossa seleção. Após o ano 2000, outras áreas vão incorporando esse tema aos seus estudos, e, no período mais recente, de 2011 a 2016, as teses e dissertações são originárias de 12 áreas distintas, incluindo campos de conhecimento como psicologia, antropologia e educação ambiental.

Nesse recorte, não há estudos de áreas como administração, economia e direito, que também possuem grande produção sobre o tema. Isso ocorre porque na classificação do Catálogo de teses e dissertações da Capes essas áreas estão registradas em "Grande área de conhecimento ciências sociais aplicadas". No entanto, pelo que pudemos observar pelos documentos analisados no capítulo 1, essas áreas concentram estudos que analisam o processo de terceirização e não as condições e relações de trabalho.

TABELA 3 - Distribuição das Teses e Dissertações sobre condições e relações de trabalho dos terceirizados por área-programa de pós-graduação, 1995 a 2016, Brasil

\begin{tabular}{lcc}
\hline Área do programa de pós-graduação & Total & $\%$ \\
\hline Ciências Sociais & 31 & 27,2 \\
\hline Sociologia & 33 & 28,9 \\
\hline $\begin{array}{l}\text { Geografia, Geografia humana e Ciências sociais em } \\
\text { desenvolvimento regional }\end{array}$ & 11 & 9,6 \\
\hline $\begin{array}{l}\text { Educação } \\
\text { Psicologia, Psicologia social (incluídos Psicologia social e } \\
\text { Institucional; e Psicologia social, do Trabalho e das } \\
\text { organizações) }\end{array}$ & 13 & 11,4 \\
\hline Sociologia e Antropologia & 11 & 9,6 \\
\hline Sociologia política & 4 & 3,5 \\
\hline História & 3 & 2,6 \\
\hline Antropologia e antropologia social & 2 & 1,8 \\
\hline $\begin{array}{l}\text { Planejamento e Políticas Públicas e Gestão de políticas } \\
\text { públicas e segurança social }\end{array}$ & 2 & 1,8 \\
\hline Ciência Política & 2 & 1,8 \\
\hline Educação ambiental & 1 & 0,9 \\
\hline Total & 1 & 0,9 \\
\hline
\end{tabular}

Fonte: Banco de Teses e Dissertações da CAPES. Elaboração própria, 2018.

A Tabela 4 (página 69) apresenta a distribuição das teses e dissertações sobre condições e relações de trabalho dos terceirizados nas universidades em que foram apresentadas. Apesar de haver representação de todas as regiões, 
há uma representação menor da região Nordeste e principalmente da região Norte, se compararmos a um indicador de número de Instituições de Educação superior nessas regiões ${ }^{34}$. No entanto, são tantos os fatores que podem fazer com que esse tema seja mais presente na região Sul e Sudeste, como os impactos dos processos de terceirização nas indústrias, fortemente localizadas nessas regiões devido ao processo de industrialização do país, ou ainda, o maior acesso ao ensino universitário nessas regiões. De todo modo, a seleção de documentos analisados nessa pesquisa conta com uma produção apresentada em 39 universidades distintas no território nacional.

TABELA 4 - Distribuição das Teses e Dissertações sobre condições e relações de trabalho dos terceirizados por universidade, 1995 a 2016, Brasil

\begin{tabular}{|c|c|c|c|c|}
\hline Universidade & Cidade & UF & Total & $\%$ \\
\hline Nordeste & & & 24 & 21,1 \\
\hline $\begin{array}{l}\text { Universidade Federal Do Recôncavo Da } \\
\text { Bahia }\end{array}$ & Cruz das Almas & $\mathrm{BA}$ & 1 & 0,9 \\
\hline Universidade Estadual De Feira De Santana & $\begin{array}{l}\text { Feira de } \\
\text { Santana }\end{array}$ & $\mathrm{BA}$ & 1 & 0,9 \\
\hline Universidade Federal Da Bahia & Salvador & $\mathrm{BA}$ & 7 & 6,1 \\
\hline Universidade Estadual Do Ceará & Fortaleza & $\mathrm{CE}$ & 2 & 1,8 \\
\hline Universidade Federal Do Ceará & Fortaleza & CE & 4 & 3,5 \\
\hline $\begin{array}{l}\text { Universidade Federal Da Paraíba/João } \\
\text { Pessoa }\end{array}$ & João Pessoa & PB & 3 & 2,6 \\
\hline Universidade Federal De Pernambuco & Recife & $\mathrm{PE}$ & 1 & 0,9 \\
\hline Fundação Universidade Federal Do Piauí & Teresina & $\mathrm{PI}$ & 1 & 0,9 \\
\hline $\begin{array}{l}\text { Universidade Federal Do Rio Grande Do } \\
\text { Norte }\end{array}$ & Natal & $\mathrm{RN}$ & 3 & 2,6 \\
\hline Fundação Universidade Federal De Sergipe & São Cristóvão & SE & 1 & 0,9 \\
\hline Centro oeste & & & 10 & 8,8 \\
\hline Universidade De Brasília & Brasília & DF & 5 & 4,4 \\
\hline Universidade Federal De Goiás & Goiânia & $\mathrm{GO}$ & 4 & 3,5 \\
\hline $\begin{array}{l}\text { Fundação Universidade Federal De Mato } \\
\text { Grosso Do Sul }\end{array}$ & Três Lagoas & MS & 1 & 0,9 \\
\hline Sudeste & & & 55 & 48,2 \\
\hline Política Universidade Vila Velha & Vila Velha & ES & 1 & 0,9 \\
\hline $\begin{array}{l}\text { Pontifícia Universidade Católica De Minas } \\
\text { Gerais }\end{array}$ & Belo Horizonte & $M G$ & 2 & 1,8 \\
\hline Universidade Federal De Minas Gerais & Belo Horizonte & MG & 1 & 0,9 \\
\hline
\end{tabular}

\footnotetext{
${ }^{34}$ Segundo dados do MEC/INEP/DEED, 2015, a distribuição das Instituições de Educação Superior segundo região é: Norte 6,4\%; Nordeste 19,3\%; Sudeste 47,3\%; Sul 17,1\%; CentroOeste $9,9 \%$.
} 


\begin{tabular}{|c|c|c|c|c|}
\hline Universidade & Cidade & UF & Total & $\%$ \\
\hline Universidade Federal De Juiz De Fora & Juiz de Fora & MG & 1 & 0,9 \\
\hline Universidade Federal De Uberlândia & Uberlândia & MG & 2 & 1,8 \\
\hline $\begin{array}{l}\text { Política Universidade Estadual Do Norte } \\
\text { Fluminense Darcy Ribeiro }\end{array}$ & $\begin{array}{l}\text { Campos dos } \\
\text { Goytacaze }\end{array}$ & RJ & 1 & 0,9 \\
\hline Universidade Federal Fluminense & Niterói & $\mathrm{RJ}$ & 1 & 0,9 \\
\hline Universidade Cândido Mendes & Rio de Janeiro & RJ & 1 & 0,9 \\
\hline Universidade Federal Do Rio De Janeiro & Rio de Janeiro & $\mathrm{RJ}$ & 5 & 4,4 \\
\hline $\begin{array}{l}\text { Universidade Est. Paulista Júlio De } \\
\text { Mesquita Filho/Araraquara }\end{array}$ & Araraquara & $\mathrm{SP}$ & 1 & 0,9 \\
\hline $\begin{array}{l}\text { Pontifícia Universidade Católica De } \\
\text { Campinas }\end{array}$ & Campinas & $\mathrm{SP}$ & 1 & 0,9 \\
\hline Universidade Estadual De Campinas & Campinas & $\mathrm{SP}$ & 16 & 14,0 \\
\hline $\begin{array}{l}\text { Universidade Est. Paulista Júlio De } \\
\text { Mesquita Filho }\end{array}$ & Marília & $\mathrm{SP}$ & 2 & 1,8 \\
\hline $\begin{array}{l}\text { Universidade Est. Paulista Júlio De } \\
\text { Mesquita Filho }\end{array}$ & Rio Claro & $\mathrm{SP}$ & 1 & 0,9 \\
\hline Universidade Federal De São Carlos & São Carlos & $\mathrm{SP}$ & 2 & 1,8 \\
\hline $\begin{array}{l}\text { Pontifícia Universidade Católica De São } \\
\text { Paulo }\end{array}$ & São Paulo & $\mathrm{SP}$ & 7 & 6,1 \\
\hline Universidade De São Paulo & São Paulo & $\mathrm{SP}$ & 6 & 5,3 \\
\hline $\begin{array}{l}\text { Universidade Est. Paulista Júlio De } \\
\text { Mesquita Filho }\end{array}$ & São Paulo & $\mathrm{SP}$ & 3 & 2,6 \\
\hline Universidade Nove De Julho & São Paulo & $\mathrm{SP}$ & 1 & 0,9 \\
\hline Norte & & & 2 & 1,8 \\
\hline Universidade Federal Do Pará & Belém & PA & 2 & 1,8 \\
\hline Sul & & & 23 & 20,2 \\
\hline Universidade Federal Do Paraná & Curitiba & PR & 2 & 1,8 \\
\hline Universidade Tuiuti Do Paraná & Curitiba & $\mathrm{PR}$ & 1 & 0,9 \\
\hline Universidade Estadual De Londrina & Londrina & PR & 1 & 0,9 \\
\hline Universidade Federal De Pelotas & Pelotas & $\mathrm{RS}$ & 2 & 1,8 \\
\hline $\begin{array}{l}\text { Universidade Federal Do Rio Grande Do } \\
\text { Sul }\end{array}$ & Porto Alegre & RS & 5 & 4,4 \\
\hline Universidade Federal Do Rio Grande & Rio Grande & $\mathrm{RS}$ & 1 & 0,9 \\
\hline Universidade Federal De Santa Maria & Santa Maria & $\mathrm{RS}$ & 2 & 1,8 \\
\hline $\begin{array}{l}\text { Política Universidade Federal De Santa } \\
\text { Catarina }\end{array}$ & Florianópolis & SC & 2 & 1,8 \\
\hline Universidade Federal De Santa Catarina & Florianópolis & SC & 7 & 6,1 \\
\hline
\end{tabular}

Fonte: Banco de Teses e Dissertações da CAPES. Elaboração própria, 2018.

Como dito acima, o nosso estudo se propõe a sistematizar as informações, análises, dados disponíveis na produção acadêmica que tratam das relações e condições de trabalho dos terceirizados. Nesse sentido, uma das informações relevantes na seleção das teses e dissertações que fazem 
parte dessa análise são os objetos investigados nesses documentos.

$\mathrm{Na}$ Tabela 5 (página 72), é possível observar que "trabalhadores terceirizados" é o objeto de pesquisa mais frequente, destacado em $23,7 \%$ das teses e dissertações analisadas, seguida por "trabalhadores diretos e terceirizados" com 19,3\%. Esses dois grupos são estudos que buscam apresentar análises comparativas entre as condições e relações de trabalho entre aqueles diretamente contratados pelas empresas e aqueles que executam suas atividades laborais com vínculos terceirizados.

A palavra-chave "Trabalhadores" possui $11,4 \%$ dos documentos analisados, onde as análises têm por objetivo identificar as transformações no mundo do trabalho e os impactos para os trabalhadores, considerando suas diferentes inserções, dentre eles, os trabalhadores terceirizados. Ainda que em menor número, alguns estudos apresentam importante análise sobre aspectos dos processos de terceirização e seus impactos para os trabalhadores, como as cooperativas que camuflam uma relação de trabalho terceirizado ou a perspectiva das mulheres trabalhadoras terceirizadas. 
TABELA 5 - Distribuição das Teses e Dissertações sobre condições e relações de trabalho dos terceirizados por objeto investigado, 1995 a 2016, Brasil

\begin{tabular}{l|c|c}
\hline Objeto investigado & Total & $\%$ \\
\hline Trabalhadores terceirizados & 27 & 23,7 \\
\hline Trabalhadores diretos e terceirizados & 13 & 19,3 \\
\hline Trabalhadores & 12 & 11,4 \\
\hline Processo de terceirização e trabalhadores & 7 & 10,5 \\
\hline Trabalhadoras e trabalhadoras terceirizadas & 5 & 6,1 \\
\hline Trabalhadores em cooperativas de trabalho & 4 & 4,4 \\
\hline $\begin{array}{l}\text { Trabalhadores diretos, terceirizados e dirigentes } \\
\text { sindicais }\end{array}$ & 3 & 3,5 \\
\hline Território & 3 & 2,6 \\
\hline Trabalhadores diretos e trabalhadores em cooperativas & & 2,6 \\
& 2 & 1,8 \\
\hline Organizações do mundo do trabalho & 2 & 1,8 \\
\hline Reestruturação produtiva & 2 & 1,8 \\
\hline Trabalhadores diretos, terceirizados e precários & 2 & 1,8 \\
\hline Trabalhadores precários & 2 & 1,8 \\
\hline Trabalhadores subcontratados & 1 & 0,9 \\
\hline Dirigentes sindicais & 1 & 0,9 \\
\hline Empreendedores produtivos & 1 & 0,9 \\
\hline Formação profissional & 1 & 0,9 \\
\hline $\begin{array}{l}\text { Fornecedores, dirigentes sindicais, trabalhadores } \\
\text { terceirizados }\end{array}$ & & \\
\hline Indústria & 1 & 0,9 \\
\hline Trabalhadores diretos, terceirizados e informais & 1 & 0,9 \\
\hline Trabalhadores terceirizados, dirigentes sindicais e \\
operadores da Justiça do Trabalho
\end{tabular}

Fonte: Banco de Teses e Dissertações da CAPES, Bibliotecas e repositórios institucionais, BDTD, Teses e dissertações. Elaboração própria, 2018.

Os estudos selecionados são, em sua grande maioria, empíricos, realizados através de estudos de caso e versam sobre uma diversificada gama de setores de atividades econômica, da indústria, serviços, comércio, administração pública e agropecuária (Tabela 6, página 74). Dentre esses setores, $53,5 \%$ são investigações em empresas privadas e $32,5 \%$ na administração pública direta ou indireta. Esses estudos representam um universo de 56 empresas identificadas como locais, onde as pesquisas foram desenvolvidas (Quadro 4, página 75).

Além de uma abrangência setorial diversa, elemento importante para a análise que queremos realizar, chama atenção que esses estudos tenham 
escolhido empresas de médio e grande porte com relevâncias em seus respectivos segmentos setoriais ou, ainda, relevantes para as regiões onde estão localizadas. Pode-se destacar também o fato de muitas universidades serem escolhidas para as análises da terceirização e de seus efeitos para os trabalhadores, onde analisam também o processo de privatização dos serviços públicos, e tem também um grupo relevante de pesquisas que estuda os "aglomerados produtivos" ${ }^{35}$, como de vestuário, de calçados, de folheados e joias, entre outros.

As pesquisas sobre esses setores/empresas majoritariamente definiram uma localidade para a realização do seu estudo de campo, isso ocorre mesmo quando a empresa tem várias filiais no país. Essas empresas estão distribuídas em 71 cidades, além de estudos que abarcam regiões no território nacional (regiões metropolitanas, regiões naturais, regiões dentro dos estados, os próprios estados) e ainda duas pesquisas que realizam estudos comparativos entre cidades brasileiras e cidades fora do país.

350 termo "aglomerados produtivos" foi utilizado para designar os estudos que analisam um conjunto de empresas, em determinada localidade, que se instalam nesse local seja pela relação de complementaridade produtiva, mesmo que marcada pela hierarquia de empresas maiores e empresas menores, seja pelo estabelecimento de políticas públicas, ou ainda pela oferta de mão de obra, e que tem sua produção voltada para um produto ou uma gama de produtos (CORDEIRO, 2015). 
TABELA 6 - Distribuição das Teses e Dissertações sobre condições e relações de trabalho dos terceirizados por setores de atividade econômica, 1995 a 2016, Brasil

\begin{tabular}{lcc}
\hline Setores de atividade econômica & Total & $\%$ \\
\hline Indústria têxtil e de confecção & 18 & 15,8 \\
\hline Educação & 13 & 11,4 \\
\hline Petróleo e gás & 9 & 7,9 \\
\hline Atividades financeiras & 8 & 7,0 \\
\hline Indústria & 8 & 7,0 \\
\hline Saúde & 6 & 5,3 \\
\hline Asseio e conservação & 5 & 4,4 \\
\hline Indústria automobilística & 5 & 4,4 \\
\hline Indústria de calçados & 5 & 4,4 \\
\hline Informação e comunicação & 4 & 3,5 \\
\hline GTD de energia elétrica & 3 & 2,6 \\
\hline Telecomunicações & 3 & 2,6 \\
\hline Administração Pública & 2 & 1,8 \\
\hline Construção civil & 2 & 1,8 \\
\hline Limpeza urbana & 2 & 1,8 \\
\hline Agropecuária & 1 & 0,9 \\
\hline Vigilância & 1 & 0,9 \\
\hline Assistência Social & 1 & 0,9 \\
\hline Comércio varejista & 1 & 0,9 \\
\hline Extrativa mineral & 1 & 0,9 \\
\hline Indústria de folheados e joias & 1 & 0,9 \\
\hline Indústria de papel e celulose & 1 & 0,9 \\
\hline Indústria do alumínio & 1 & 0,9 \\
\hline Indústria metalúrgica & 1 & 0,9 \\
\hline Indústria Naval & 1 & 0,9 \\
\hline Indústria siderúrgica & 1 & 0,9 \\
\hline Setor imobiliário & 1 & 0,9 \\
\hline Transporte terrestre & 1 & 0,9 \\
\hline ND (Não Disponível) & 5 & 4,4 \\
\hline NSA (Não Se Aplica) & 5 & 4,4 \\
\hline Total & $\mathbf{1 1 4}$ & $\mathbf{1 0 0}$ \\
\hline Fote: Banco de Teses e Disser & 1 & \\
\hline
\end{tabular}

Fonte: Banco de Teses e Dissertações da CAPES, Bibliotecas e repositórios institucionais, BDTD, Teses e dissertações. Elaboração própria, 2018. 
QUADRO 4 - Empresas objeto de estudo das Teses e Dissertações sobre condições e relações de trabalho dos terceirizados selecionadas, 1995 a 2016, Brasil

\begin{tabular}{|c|c|}
\hline \multicolumn{2}{|c|}{ Empresas estudadas } \\
\hline Aglomerações produtivas (12) & $\begin{array}{l}\text { Hospital Universitário João de Barros } \\
\text { Barreto }\end{array}$ \\
\hline Albrás Alunorte & IFES \\
\hline Alfa & Inditex e Multifibras \\
\hline Banco "oficial" & Levi Strauss \\
\hline Banco Popular & Lupo \\
\hline Bancos & MMC Automotores \\
\hline CEF - Caixa Econômica Federal (2) & Multiserv \\
\hline Cemig & $\begin{array}{l}\text { ND (37; Não está disponível no } \\
\text { Resumo informações sobre qual é a } \\
\text { empresa investigada) }\end{array}$ \\
\hline Centro Industrial Subaé & NSA (8) \\
\hline Cirne, Salute, Têxtil & OI Contax e Oi Telemar \\
\hline Codin, Cotrês, Coita, Dilly & Petrobrás \\
\hline $\begin{array}{l}\text { Complexo petroquímico de Camaçari } \\
\text { (2) }\end{array}$ & Petrobrás - Bacia de Campos \\
\hline Cooperativas & Prefeitura - Teresina/PI \\
\hline $\begin{array}{l}\text { COOPES - Cooperativa Educacional } \\
\text { das Profissionais do Ensino Superior }\end{array}$ & Refinaria Landulpho Alves (4) \\
\hline Copel & Funcamp \\
\hline Correios & $\begin{array}{l}\text { Secretaria Municipal de Saúde - São } \\
\text { Paulo/SP }\end{array}$ \\
\hline CREAS & Subcontratadas Petrobras \\
\hline $\begin{array}{l}\text { CSN - Companhia Siderúrgica } \\
\text { Nacional }\end{array}$ & Telemar \\
\hline DETRAN RJ & Triumph \\
\hline Empresas de Ferro gusa & UFBA \\
\hline Escolas da rede estadual - Marília/SP & UNB \\
\hline $\begin{array}{l}\text { Escolas da rede estadual - } \\
\text { Tabatinga/DF }\end{array}$ & Unicentro; UEM; Unioeste \\
\hline Fibria & Universidade de Lavras \\
\hline Ford & Universidade Estadual do Ceará \\
\hline $\begin{array}{l}\text { FURG - Universidade Federal do Rio } \\
\text { Grande }\end{array}$ & Universidade federal de Uberlândia \\
\hline GM - General Motors & $\begin{array}{l}\text { Universidade Federal do Recôncavo } \\
\text { da Bahia }\end{array}$ \\
\hline Honda & USP \\
\hline Hospital Santa Lucia & Volkswagen \\
\hline
\end{tabular}

Fonte: Banco de Teses e Dissertações da CAPES, Bibliotecas e repositórios institucionais, BDTD, Teses e dissertações. Elaboração própria, 2018. 


\subsection{Dimensões e temas para a construção dos indicadores de precarização das condições e relações de trabalho}

Nesta seção, apresentaremos uma grade de temas que irá orientar a leitura e sistematização das teses e dissertações, colaborando com a construção dos indicadores de precarização das condições e relações de trabalho dos terceirizados no Brasil. Os indicadores podem contribuir de forma significativa para o balanço desse grupo de teses e dissertações que estamos analisando, podem colaborar destacando convergências e especificidades e podem ajudar a constituir um painel com uma análise nacional da terceirização e seus efeitos. Como propõe Januzzi (2006), um indicador social é diferente de uma estatística (um dado bruto) e deve ter como características, entre outras, relevância social, capacidade de refletir o conceito abstrato que se propõe representar, grau de cobertura, transparência na metodologia e confiabilidade referente à qualidade das informações utilizadas:

Um indicador social é uma medida em geral quantitativa, dotada de significado social substantivo, usado para substituir, quantificar ou operacionalizar um conceito social abstrato, de interesse teórico (para a pesquisa acadêmica) ou programático (para formulação de políticas). (JANUZZI, 2006, p. 15).

A metodologia utilizada foi definida a partir das referências apresentadas no projeto de pesquisa "A Precarização Social do Trabalho: uma proposta de construção de indicadores" ${ }^{\prime \prime 6}$. Como poderemos ver a seguir, a grade tem como chave principal o trabalho terceirizado e as características que, a partir da leitura das fichas catalográficas e resumos das teses e dissertações disponíveis na Capes/Sucupira e na grande área de Ciências Humanas, se apresentaram em evidência: perfil dos trabalhadores terceirizados, condições de trabalho, relações de trabalho, sobreposição com outras formas precárias de trabalho, entre outros. Essa base selecionada é formada em grande parte por estudos de caso, com pesquisas do tipo empírica e que fornecem uma relevante fonte de informações qualitativas sobre o trabalho terceirizado, além

\footnotetext{
${ }^{36}$ Informações sobre o projeto, coordenado por Graça Druck. Disponível em: <http://www.flexibilizacao.ufba.br/projetos_atuais.asp>. Acesso em: jan. 2018.
} 
de se constituir como uma fonte mais homogênea na apresentação das análises, dados e informações.

Os temas descritos na tabela abaixo (Tabela 7, página 78) estão presentes nos títulos e nos resumos das teses e dissertações aqui selecionadas, como demonstração das formas que assume a precarização do trabalho, como resultado dos processos de terceirização. Alguns aparecem com bastante frequência, outros, apesar da baixa frequência, foram mantidos devido à importância do tema para a caracterização das condições e relações de trabalho dos terceirizados, como, por exemplo, o trabalho infantil. Os temas que tiveram menor citação nas fichas catalográficas e títulos também foram mantidos, porque essa listagem será um guia para análise das teses e dissertações e alguns temas podem estar contidos nos textos e não terem aparecido no título ou resumo - inclusive porque muitos resumos apresentam uma caracterização mais geral, com títulos como "condições de trabalho", ou "perfil do trabalhador", ou ainda "trabalho precário".

Cada tema abaixo será utilizado como guia para busca nas teses e dissertações, por exemplo, no item contratos precários procuraremos nas teses e dissertações informações sobre contratos temporários, cooperados, informais, entre outros. Outro exemplo, em jornada de trabalho, procuraremos ampliação da jornada, intensificação do ritmo de trabalho, ampliação das horas extras.

É possível notar que as análises sobre os efeitos da terceirização sobre as condições e as relações de trabalho atingem uma ampla gama de temas que se relacionam com a vida do trabalhador, dentro e fora do espaço em que executa suas atividades profissionais. 
TABELA 7 - Temas presentes nas teses e dissertações sobre condições e relações de trabalho dos terceirizados, 1995-2016, Brasil (Múltipla resposta)

\begin{tabular}{|c|c|c|}
\hline Temas & Total & $\%$ \\
\hline Condições de trabalho & 57 & 50,0 \\
\hline Ação sindical & 33 & 28,9 \\
\hline Remuneração & 30 & 26,3 \\
\hline Identidade & 21 & 18,4 \\
\hline Subjetividade no trabalho & 17 & 14,9 \\
\hline Relações de trabalho & 16 & 14,0 \\
\hline Saúde e Segurança & 16 & 14,0 \\
\hline Trabalho feminino & 16 & 14,0 \\
\hline Formação e qualificação profissional & 13 & 11,4 \\
\hline Jornada de trabalho & 12 & 10,5 \\
\hline Emprego & 11 & 9,6 \\
\hline Rotatividade & 11 & 9,6 \\
\hline Ação coletiva & 10 & 8,8 \\
\hline Direitos trabalhistas e Benefícios & 10 & 8,8 \\
\hline Condições de vida & 10 & 8,8 \\
\hline Trabalho precário & 10 & 8,8 \\
\hline Informalidade & 8 & 7,0 \\
\hline Trabalho em cooperativa & 8 & 7,0 \\
\hline Contrato de trabalho & 7 & 6,1 \\
\hline Organização e processo de trabalho & 6 & 5,3 \\
\hline Perfil dos trabalhadores & 5 & 4,4 \\
\hline Relações interpessoais & 5 & 4,4 \\
\hline Violação de direitos & 5 & 4,4 \\
\hline Progressão profissional & 4 & 3,5 \\
\hline Segmentação do trabalho & 4 & 3,5 \\
\hline Isonomia de direitos & 3 & 2,6 \\
\hline Discriminação & 2 & 1,8 \\
\hline Trabalho a domicilio & 2 & 1,8 \\
\hline Trabalho de jovens & 2 & 1,8 \\
\hline Contrato temporário & 1 & 0,9 \\
\hline Pejotização & 1 & 0,9 \\
\hline Trabalho escravo & 1 & 0,9 \\
\hline Trabalho infantil & 1 & 0,9 \\
\hline Trabalho negros & 1 & 0,9 \\
\hline Trabalho temporário & 1 & 0,9 \\
\hline Total & 114 & 100,0 \\
\hline
\end{tabular}

Fonte: Banco de Teses e Dissertações da CAPES, Bibliotecas e repositórios institucionais, BDTD, Teses e dissertações. Elaboração própria, 2018. 
Apoiados na análise bibliométrica realizada no presente capítulo, destacamos: (1) os documentos selecionados para a leitura do conteúdo que estão alinhados com os objetivos da pesquisa; (2) os principais temas, destacados na presente análise bibliométrica, que serão um guia para a leitura dos documentos e para a seleção de trechos e de informações que possibilitem o balanço sobre a produção acadêmica sobre terceirização com a constituição de indicadores de precarização. 


\section{Impactos da terceirização para as relações de trabalho}

Nesse capítulo apresentaremos a metodologia utilizada para o balanço das teses e dissertações que tem como foco as condições e relações de trabalho dos terceirizados. Nessa síntese, consideramos o conteúdo presente nestes documentos, com destaque para o levantamento empírico em cada pesquisa, material que utilizaremos como base primária para nosso estudo.

A análise está dividia em quatro eixos: (1) Condições de trabalho, (2) Contrato individual de trabalho, (3) Saúde do trabalhador, e (4) Ação coletiva e sindical. Com base no resultado do capítulo anterior, também havíamos destacado o eixo Identidade e subjetividade no trabalho, no entanto, após a leitura, sistematização e análise das informações, chegamos a conclusão que não seria possível realizar uma reflexão sobre esse eixo com consistência. Há uma diversidade de usos sobre esses termos, algumas vezes sem precisão conceitual, outras sem uma conexão com as informações coletadas no estudo de campo.

$\mathrm{Na}$ sequência, ainda neste capítulo, apresentaremos na seção Terceirização e precarização: um recorte setorial, uma recuperação dos debates realizados no capítulo anterior e no presente capítulo, buscando confrontar os resultados da pesquisa com nosso objetivo, perguntas e hipóteses apresentadas na introdução.

\subsection{A coleta das teses e dissertações completas}

É importante destacar que, do total de 235 teses e dissertações existentes no Catálogo da CAPES (conforme descrito no Capítulo 2) na "Grande área de conhecimento Ciências Humanas", 114 tratam do escopo definido aqui na pesquisa: impacto das terceirizações para as relações de 
trabalho. Para coletar essas teses e dissertações em arquivo eletrônico ${ }^{37}$ foram realizadas diversas tentativas: em primeiro lugar, aquelas que estavam disponíveis na Plataforma Sucupira; depois, uma busca na Biblioteca Digital Brasileira de Teses e Dissertações (BDTD); e, finalmente, nos repositórios institucionais de teses e dissertações de cada biblioteca onde esses documentos foram depositados.

Nos casos em que foi possível, realizamos a consulta nas bibliotecas físicas, quando localizadas em São Paulo. No Instituto de Psicologia da Universidade de São Paulo - IP/USP e na Faculdade de Filosofia Letras, Ciência Humanas da Universidade de São Paulo - FFLCH/USP houve a permissão para digitalizar os capítulos que fossem mais importantes para a pesquisa. Na Pontifícia Universidade Católica de São Paulo - PUC/SP não havia autorização dos autores para nenhum tipo de manipulação digital dos documentos. Outra tentativa foi encontrar os autores em sites de busca, redes sociais e no Currículo Lattes.

As demais teses e dissertações foram solicitadas via email ou contato telefônico na Biblioteca onde o documento foi depositado. Em quatro casos de solicitação feita às bibliotecas a resposta foi negativa, seja porque o documento foi extraviado da biblioteca, porque houve incêndio e o documento foi destruído, ou, ainda, porque não havia nenhuma possibilidade de digitalização, por falta de autorização dos autores ou equipamento adequado. Em outros, por orientação da biblioteca, solicitamos os documentos através do Serviço de Comutação Bibliográfica (Comut), mas a devolutiva foi bastante negativa: em alguns casos, não havia permissão por escrito do autor para que a biblioteca colocasse à disposição o documento; em outros, não houve resposta ao pedido; apenas um documento dentre os solicitados foi obtido nessa modalidade.

No momento final da coleta, das 114 teses e dissertações, contávamos com 90 documentos, o que representa $79 \%$ do universo que gostaríamos de

\footnotetext{
${ }^{37}$ Considerando o volume de informações sistematizamos, foi necessário utilizar um software, - Atlas.TI, que auxilia na organização desse conteúdo. Para tanto, é necessário que os documentos estejam disponíveis em uma versão eletrônica.
} 
analisar. Os documentos não encontrados estão listados no Anexo III, página 224.

Como destacado no capítulo 2, apesar dos avanços em digitalizar esse tipo de produção científica, ainda há um percurso a percorrer para promover maior acesso e difusão da produção acadêmica nesse formato (teses e dissertações).

\subsection{A Revisão Bibliográfica Sistemática}

Como dito anteriormente, a maior parte das pesquisas sobre condições e relações de trabalho dos terceirizados usa o estudo de caso e a pesquisa empírica como escolhas metodológicas privilegiadas para entender 0 fenômeno. Para nossa pesquisa, as informações apresentadas nesses estudos são a base fundamental: são dados, informações, descrições das condições e relações de trabalho aos quais as trabalhadoras e trabalhadores terceirizados estão submetidos, avaliações desses trabalhadores e de suas representações sindicais sobre sua realidade laboral, entre outros.

Esses dados estão dispersos e sistematizá-los contribui para entender a terceirização como um processo efetivo de precarização das condições de trabalho, quais características são recorrentes e quais são particulares, considerando os diversos setores de atividade econômica.

Segundo Bardin (2011), a análise de conteúdo ou análise documental é um método de pesquisa empírico e ocupa-se de uma descrição objetiva, sistemática e quantitativa do conteúdo extraído das comunicações científicas (teses, dissertações, artigos). A análise documental, segundo a autora, tem o foco nos documentos (unidades de pesquisa) e procura estabelecer uma classificação através da indexação das informações, apresentando-as de modo condensado. Para isso, é necessário estabelecer regras claras para seleção dos documentos e para a codificação e classificação das informações.

Em nossa análise documental iremos utilizar a Revisão Bibliográfica Sistemática (RBS) como método de seleção, codificação, sistematização e 
análise das informações. Nesse tipo de investigação, as unidades de pesquisa (teses e dissertações) caracterizam-se como fontes para o preenchimento de um "questionário", ou seja, pela procura de dados e informações que preencham critérios pré-determinados (AQUINO, SABOIA, MELO, CARVALHO, XIMENES, 2015). Em nossa pesquisa, os critérios prédeterminados chamaremos de códigos (Tabela 7, página 78).

A RBS é um método científico para busca e análise de comunicações de um determinado campo de conhecimento. Não se trata de um levantamento da literatura existente, mas de um estudo síntese que testa uma hipótese (GOMES, CAMINHA, 2014). É amplamente utilizada em pesquisas na medicina, psicologia e em algumas áreas das ciências sociais, em que há um grande volume de estudos e pesquisas publicados, constituindo-se como fontes de informações sobre determinado assunto (CONFORTO, AMARAL, SILVA, 2011). É um estudo secundário em que a base primária de informações é os documentos científicos selecionados.

A RBS requer, como passos da investigação, a definição de uma pergunta de pesquisa e que, ao final, seja apontada uma novidade na análise em relação ao objeto estudado (GARCIA, 2014). Ela possibilita consolidar evidências e os resultados obtidos em estudos anteriores, além de identificar lacunas na teoria e nas pesquisas do campo, promovendo novas agendas de pesquisa (CONFORTO, AMARAL, SILVA, 2011). A RBS, em estudos qualitativos, deve assegurar a validade descritiva (identificação dos estudos relevantes), interpretativa (o conteúdo do estudo e o registro do revisor) e teórica (os métodos utilizados) (GOMES, CAMINHA, 2014). Essas pesquisas devem apresentar a descrição do percurso metodológico utilizado, garantindo a possibilidade de sua reprodutibilidade. Em resumo:

Essas revisões são consideradas estudos observacionais retrospectivos ou estudos experimentais de recuperação e análise crítica da literatura. Testam hipóteses e têm como objetivo levantar, reunir, avaliar criticamente a metodologia da pesquisa e sintetizar os resultados de diversos estudos primários. Busca responder a uma pergunta de pesquisa claramente formulada. Utiliza métodos sistemáticos e explícitos para recuperar, selecionar e avaliar os resultados de estudos relevantes. Reúne e sistematiza os dados dos estudos primários 
(unidades de análise). (Biblioteca Prof. Paulo C Mattos, UNESP/Botucatu, 2015).

Os estudos primários, pela sua diversidade e grande número disponível, como no caso da terceirização, permitem uma análise com conclusões que trazem novos elementos para o campo investigado. É um estudo de síntese, de balanço, mas que procura responder uma questão, além de colaborar com novas agendas de estudo em qualquer área ou campo disciplinar.

Os passos para a realização da Revisão Bibliográfica Sistemática podem ter pequenas alterações entre um método e outro, mas podem ser condensados em três etapas principais: entrada/seleção dos documentos, processamento e análise. Em nossa pesquisa essas etapas se desdobraram do seguinte modo:

- Fase 1: definição do problema, objetivos e hipóteses;

- Fase 2: critérios para seleção de artigos (qual a base de dados a ser utilizada para coleta de documentos; qual o período de abrangência dos documentos; quais os "termos livres" ou "descritores" de busca e de coleta dos documentos);

- Fase 3: mapeamento (análise bibliométrica, através das fichas catalográficas das teses e dissertações), para elaborar os critérios de inclusão e exclusão de documentos;

- Fase 4: elaboração dos códigos para seleção das informações nos documentos completos;

- Fase 5: Sistematização das informações e análise final.

De modo sintético, o percurso percorrido na pesquisa foi o seguinte: 
FIGURA 2 - Etapas da pesquisa

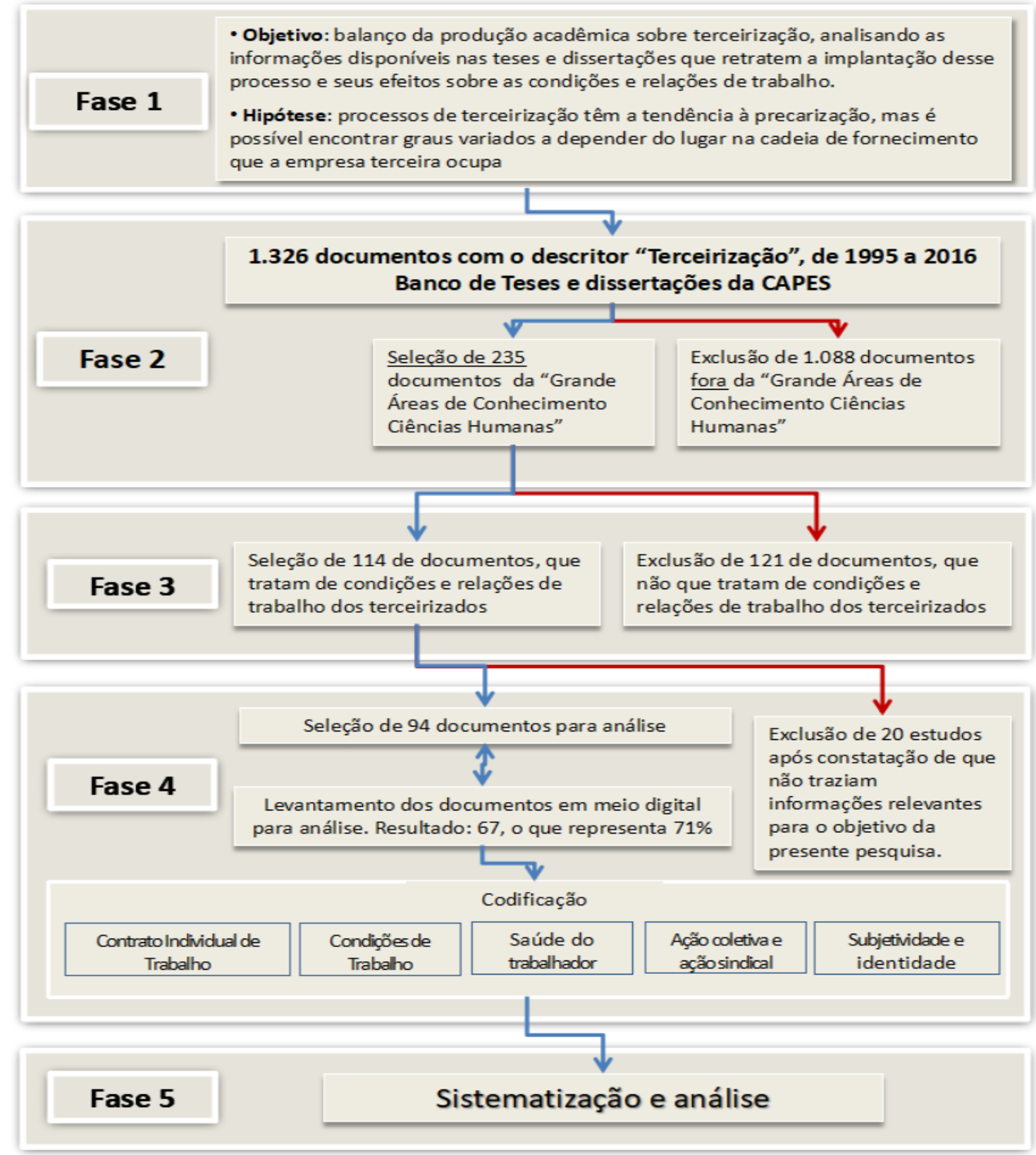

Nota: quadro elaborado a partir da literatura sobre RBS. Elaboração própria.

As teses e dissertações selecionadas são nossos estudos primários, e cada um é considerado uma "unidade de pesquisa", ou seja, ainda que exista mais de uma empresa estudada, ou relatos distintos de mais de um trabalhador, consideraremos apenas como 1 (uma) ocorrência. Optamos por essa escala (cada tese ou dissertação 1 unidade) porque há diferenças metodológicas, principalmente entre pesquisas quantitativas e qualitativas, 0 que poderia dar um peso equivocado para uma pesquisa em detrimento de 
outra. Cada ocorrência destacada no texto durante a leitura foi codificada com um código de um determinado eixo e também com uma cidade e um setor de atividade econômica. Depois de realizada a leitura e classificação do material, os códigos permitem resgatar o conteúdo em diversos recortes distintos, para realização posterior da análise, segundo os eixos definidos e os objetivos da pesquisa. Para codificar as ocorrências utilizamos a lista de códigos abaixo.

QUADRO 5 - Eixos e códigos para elaboração da Revisão Bibliográfica Sistemática (RBS)

\begin{tabular}{|c|c|}
\hline Eixos & Códigos \\
\hline Condições de trabalho & $\begin{array}{l}\text { - } \text { - } \text { Conefícios } \\
\text { - } \text { Direitos traba de vida } \\
\text { - } \text { Formação e qualificação } \\
\text { - Treinamento } \\
\text { - Hora extra } \\
\text { - Jornada de trabalho } \\
\text { - } \text { Organização e processo de trabalho } \\
\text { - } \text { Progressão profissional } \\
\text { - Remuneração } \\
\text { - Ritmo de trabalho } \\
\text { - } \text { Segatividade e tempontação no trabalho emprego } \\
\text { - Verbas rescisórias } \\
\text { - Violação de direitos }\end{array}$ \\
\hline $\begin{array}{l}\text { Contrato individual de } \\
\text { trabalho }\end{array}$ & $\begin{array}{l}\text { - Emprego } \\
\text { - Informalidade } \\
\text { - "Pejotização" } \\
\text { - "Quarteirização" } \\
\text { - Trabalho a domicílio } \\
\text { - Trabalho em cooperativas } \\
\text { - Trabalho infantil } \\
\text { - Trabalho temporário } \\
\text { - Trabalho escravo } \\
\text { - Trabalho precário }\end{array}$ \\
\hline Saúde do trabalhador & $\begin{array}{l}\text { - Acidentes de trabalho } \\
\text { - Ambiente de trabalho } \\
\text { - Assédio moral e sexual } \\
\text { - } \text { Doenças de trabalho } \\
\text { - Equipamentos de proteção e segurança } \\
\text { individual e coletivos }\end{array}$ \\
\hline Ação coletiva e sindical & - Ação coletiva \\
\hline
\end{tabular}




\begin{tabular}{|c|c|}
\hline Eixos & Códigos \\
\hline & $\begin{array}{l}\text { - Ação institucional do Estado } \\
\text { - Ação sindical } \\
\text { - Rráticas antissindicais } \\
\text { - Relações entre empregadores e trabalhadores } \\
\text { - Relações de trabalho democráticas/autoritárias }\end{array}$ \\
\hline Perfil dos trabalhadores & $\begin{array}{l}\text { - Escolaridade } \\
\text { - Perfil dos trabalhadores } \\
\text { - Trabalho feminino } \\
\text { - Trabalho jovem } \\
\text { - Trabalhadoras e trabalhadores negros }\end{array}$ \\
\hline Contexto dos documentos & $\begin{array}{l}\text { - Conceitos e autores } \\
\text { - Conceitos terceirização } \\
\text { - Opções metodológicas, hipóteses e objetivos } \\
\text { - } \text { Setores }^{*} \\
\text { - } \text { Empresas }^{*} \\
\text { - } \text { Cidades }^{*}\end{array}$ \\
\hline
\end{tabular}

*Nesses casos, há diversos códigos para cada item, que considera todos os setores econômicos presentes nos estudos, as empresas e as cidades.

Foram codificadas também informações relativas ao perfil dos trabalhadores e trabalhadoras, além de informações sobre a pesquisa, como os principais conceitos e autores utilizados como marco teórico, com destaque para as definições de terceirização e seus autores. Foram codificadas também as opções metodológicas, as hipóteses e os objetivos. Essas informações não foram sistematizadas e analisadas, mas serviram de material de apoio para a análise e para as consultas necessárias durante o processo da pesquisa.

Para a classificação de cada informação codificada seguimos o seguinte critério: quando há divergência entre os entrevistados sobre determinado código, quando ele não acomete todos os trabalhadores, ou ainda quando ele é um episódio eventual, classificamos com "ocorrência, em parte"; quando há afirmações positivas sobre o código, abrangendo a maior parte dos trabalhadores ou com frequência, classificamos com "ocorre com frequência"; e quando há negativa em relação ao código, classificamos como "não tem essa ocorrência". Quando a pesquisa de campo não tem informação sobre um código específico, classificamos como "ND” (Não disponível).

A manipulação dos documentos se deu com as seguintes orientações: 
- Utilizamos, em cada documento, a introdução, para localizar a pesquisa: metodologia, conceitos, objeto; mas a base para a sistematização foram os capítulos que apresentavam o resultado do estudo de caso, da pesquisa de campo.

- Critérios para codificação: somente os dados primários coletados na pesquisa, com exemplos objetivos sobre as condições de trabalho, de vida e as relações de trabalho dos terceirizados; as comparações entre trabalhadores diretos e terceirizados; e as falas dos trabalhadores terceirizados;

- As falas dos dirigentes sindicais foram utilizadas quando possuíam um exemplo objetivo das condições precárias dos trabalhadores terceirizados ou quando se tratava de avaliação da atividade sindical. Não destacamos avaliações decorrentes de disputas sindicais.

- Dados que foram levantados de outros estudos e de outros autores não foram utilizados para garantir que não houvesse repetições. Desse modo, apenas dados originais foram considerados.

- Pesquisas baseadas em história oral: foram selecionados apenas dados e informações sobre o período de vida em que o entrevistado estava na condição de trabalhador terceirizado.

- Pesquisas que comparam trabalhadores terceirizados com trabalhadores diretos (aqueles contratados pela empresa principal, ou tomadora): selecionamos apenas as informações que comparam as condições e relações de trabalho entre os dois grupos de trabalhadores, mas que apontam a informação do trabalho terceirizado, positivas, negativas ou neutras. Dados sobre a precarização dos trabalhadores diretos não foram selecionados.

- Nessa fase foram excluídas 20 teses e dissertações. Após a leitura do documento completo constatou-se que o conceito de terceirização utilizado não se enquadrava na definição adotada nesta dissertação. Entre esses documentos, também excluímos aquelas teses e dissertações que não foram baseadas em pesquisa empírica, portanto, apresentavam dados secundários. Por fim, também excluímos 
documentos com alguma inconsistência na apresentação dos dados (vide Anexo IV, página 224).

A codificação foi realizada com o auxílio do software Atlas.ti, que permite a codificação, sistematização e análise de grande massa de dados qualitativos. Esse software foi desenvolvimento em 1989, por Thomas Muhr, na Alemanha, e dentre suas diversas funcionalidades está a possibilidade de construir estados da arte, análise multimídia de imagens, áudios e vídeos, tratamento estatístico de dados e informações, análise de surveys, codificação de base de dados, e a sistematização de todas as etapas da Análise de Conteúdo e Documental, através da Revisão Bibliográfica Sistemática.

É importante ressaltar que o Atlas.ti é uma ferramenta que auxilia o pesquisador no processo de organização da análise dos dados. Todas as inferências e categorizações devem ser feitas pelo pesquisador, suportado pela sua base teórica (JUNIOR, LEÃO, 2018). Na presente dissertação, recorremos ao Atlas.ti para a codificação dos documentos, com o qual consolidamos a base de dados utilizada tanto para a análise do conteúdo das dissertações, quanto para a construção de variáveis quantitativas (indicadores de precarização) e para cruzamentos de ocorrências dos códigos considerando os setores e a regiões geográficas.

\subsection{Análise das relações de trabalho dos terceirizados no Brasil}

A construção dos quatro eixos que guiam a nossa análise foi definida a partir de classificação utilizada por Druck (1999) e atualizada com a análise bibliométrica das teses e dissertações sobre terceirização do trabalho, conforme exposto no capítulo 2. Além dos eixos, com base nas informações fornecidas nos títulos e nos resumos, pudemos também construir uma lista de códigos, a foram utilizados como guia para a leitura das teses e dissertações, classificando cada trecho lido com um determinado código. Esses temas foram agrupados em quatro eixos: (1) Condições de Trabalho, (2) Contrato individual de trabalho, (3) Saúde do trabalhador e (4) Ação coletiva e sindical. 
A seguir, definimos o que entendemos ser cada um desses eixos e apresentamos a análise realizada a partir do material coletado nas teses e dissertações analisadas.

É importante destacar que não estamos apresentando uma análise estatística amostral, mas sim, um painel a partir das informações coletadas e sistematizadas. Apesar de não ser uma amostra estatística, o estudo permite ter um painel bastante abrangente e consistente sobre as características e os efeitos da terceirização no Brasil, em suas diversas regiões e setores econômicos. Essa análise é possível devido à variedade dos estudos sobre terceirização e a profundidade das informações coletadas em campo.

Outro ponto importante é que os eixos e códigos são fortemente imbricados e relacionados entre $\mathrm{si}$, em nossa pesquisa apresentamos um esforço de classificação dessas categorias, para realizar nossa análise.

\subsubsection{Condições de trabalho}

O termo "Condições de trabalho" é bastante amplo, pode englobar todas as características da atividade laboral. Em nossa sistematização dividimos esse tema em três eixos, apenas para facilitar a apresentação das informações sistematizadas: Contratos individuais de trabalho, Saúde do trabalhador e Condições de trabalho. Aqui, consideramos Condições de trabalho todos os elementos que estão relacionados à jornada de trabalho, à remuneração direta e indireta, aos benefícios e aos direitos trabalhistas e previdenciários. Consideramos também que as condições de trabalho estão em transformação, mas que esse processo é permeado de contradições, em que novas formas convivem ou potencializam velhas formas de precarização (DRUCK, 2011, p. $37)$.

Vale destacar que a Reforma trabalhista de 2017 alterou, de modo profundo, diversas características relacionadas às condições de trabalho, nos termos que aqui definimos, tanto nos direitos trabalhistas, como na regulação da jornada de trabalho, na remuneração e até mesmo em itens que facilitam ainda mais a demissão dos trabalhadores e das trabalhadoras. No entanto, 
nosso corte temporal aqui analisado termina em 2016, período anterior a estas alterações.

De todo modo, é importante registrar que a reforma trabalhista inclui medidas que facilitam a demissão e reduzem a possibilidade do trabalhador reclamar os direitos trabalhistas na Justiça do Trabalho, através do fim da obrigatoriedade de rescisão na entidade sindical, do acordo anual de quitação de débitos trabalhistas e do pagamento das custas judiciais se a reclamação for considerada improcedente. Também altera a extensão da jornada de trabalho facilitando o estabelecimento da jornada de 12 horas de trabalho seguidas de 36 horas de descanso (jornada 12 x 36h), hoje restrita a situações excepcionais e condicionadas à celebração de acordo coletivo com o sindicato. Ainda no que diz respeito ao tempo de trabalho, facilita a habitualidade da jornada de 10 horas diárias (8 horas de trabalho +2 horas extras); promove os acordos individuais para estabelecimento de compensação das horas trabalhadas (banco de horas), hoje dependente de acordo coletivo com o sindicato, conforme previsão constitucional. Quanto aos demais direitos reduz ou precariza o acesso, como as novas regras que tratam das férias (que podem ser divida em 3 períodos), redução das regras que determinam a isonomia salarial e redução da proteção às mulheres gestantes, entre outros (DIEESE, 2017).

Parte importante dos direitos relativos às condições de trabalho está previsto na Constituição Federal, no artigo $7^{\circ}$. No entanto, mesmo se tratando de direitos constitucionais, eles são frequentemente desrespeitados, como veremos a frente. As condições de trabalho, em conjunto com o contrato individual de trabalho, estabelecem os termos mínimos de venda da força de trabalho, dos limites para a exploração do trabalho. As transformações ocorridas, especialmente a partir da década de 70, "significaram a ampliação da exploração dos trabalhadores, com consequente queda na qualidade das relações dentro e fora dos ambientes de trabalho" (MARCELINO, 2011, p. 57) esgarçando esses limites, seja com a conivência dos órgãos fiscalizadores, como apresentado acima no Capítulo 1, seja pela mudança na regulação do trabalho. 
Para a análise do eixo Condições de trabalho utilizaremos os seguintes códigos: Hora extra, Ritmo de trabalho, Remuneração, Benefícios, Rotatividade e tempo de emprego, Violação de direitos, Treinamento e Qualificação profissional na empresa e Discriminação do trabalhador terceirizado. A seguir, apresentamos um quadro com os códigos analisados e as evidências de precarização das condições de trabalho em cada tema.

Apesar de não termos material suficiente para elaborar um indicador sobre a precarização das Condições de vida, apresentamos abaixo, no Quadro 6 (página 92), as principais evidências registradas sobre esse tema. Entendemos que a precarização social do trabalho reflete em várias dimensões, econômica, política e social, como propõe Druck (2011, p. 37) e mesmo que as pesquisas abordem de forma muito limitada às condições de vida dos trabalhadores e suas famílias, o material sistematizado traz importantes considerações sobre esse tema.

QUADRO 6 - Códigos e evidências da precarização das Condições de trabalho dos trabalhadores e trabalhadoras terceirizados

\begin{tabular}{|l|l|}
\hline \multicolumn{1}{|c|}{ Códigos } & \multicolumn{1}{c|}{ Evidências } \\
\hline Hora extra & $\begin{array}{l}\text { - Realização de hora extra de forma contínua, habitual; } \\
\text { - Realização de horas extras acima dos limites } \\
\text { permitidos por Lei; } \\
\text { - Horas extras não pagas; } \\
\text { - Banco de horas informal, sem negociação coletiva, } \\
\text { conforme previsto em Lei; }\end{array}$ \\
\hline Ritmo de trabalho & $\begin{array}{l}\text { - Aceleração da realização das tarefas; } \\
\text { - Pressão por cumprimento de metas; } \\
\text { serviços demandados, seja pela tomadora seja pela } \\
\text { empresa terceira; } \\
\text { - Picos de produção; } \\
\text { - Eliminação de pausas para descanso previstas em } \\
\text { Lei; } \\
\text { - Reorganização dos processos de trabalho para } \\
\text { eliminação dos tempos mortos; }\end{array}$ \\
\hline
\end{tabular}




\begin{tabular}{|l|l|}
\hline \multicolumn{1}{|c|}{ Códigos } & \multicolumn{1}{c|}{ Evidências } \\
\hline Jornada de & $\begin{array}{l}\text { - Ajuste da jornada de trabalho à sazonalidade da } \\
\text { produção; } \\
\text { - Insuficiência de horas; } \\
\text { - Jornadas contratadas das trabalhadoras e } \\
\text { trabalhadores terceirizados maiores do que a contratada } \\
\text { para os trabalhadores diretamente contratados pela } \\
\text { tomadora; }\end{array}$ \\
\hline Remuneração & $\begin{array}{l}\text { - Pagamento por produção; } \\
\text { - Não pagamento de férias; } \\
\text { - Não pagamento de 13o; } \\
\text { - Remuneração menor para as mulheres; } \\
\text { - Terceirização e relocalização como forma de reduzir } \\
\text { salários; } \\
\text { - Salário dos terceirizados menor do que o salário pago } \\
\text { para os diretamente contratados, na mesma função; } \\
\text { - Remuneração menor do que 1 salário mínimo; } \\
\text { - Mais de uma ocupação, para complementação do } \\
\text { orçamento familiar; } \\
\text { - Impactos negativos da sazonalidade da produção nos } \\
\text { salário; } \\
\text { - Diferenciação salarial entre trabalhadores } \\
\text { terceirizados e diretos que trabalham na mesma função; } \\
\text { - Ter que arcar com custos do trabalho/produção, } \\
\text { pagos com parte da remuneração do próprio trabalhador; } \\
\text { - Pagamento parcial ou não pagamento de salário para } \\
\text { "aprendizes"; } \\
\text { - Diferenciação ou não pagamento de adicionais } \\
\text { (insalubridade, periculosidade, gratificações, PLR, } \\
\text { auxílios alimentação e transporte, plano de saúde); }\end{array}$ \\
\hline - Não há benefícios; \\
- Inconstância no pagamento dos benefícios; \\
- Tem, mas de qualidade e/ou valor inferior ao fornecido \\
na empresa tomadora; \\
- Menor variedade de benefícios;
\end{tabular}




\begin{tabular}{|l|l|}
\hline \multicolumn{1}{|c|}{ Códigos } & \multicolumn{1}{c|}{ Evidências } \\
\hline Violação de & $\begin{array}{l}\text { - Troca de contrato com fim de contrato entre empresas } \\
\text { ou falência da empresa; }\end{array}$ \\
direitos & $\begin{array}{l}\text { - Não cumprimento dos direitos previstos para a CTPS; } \\
\text { - Descontos indevidos na remuneração; } \\
\text { - Redução do patamar de direitos devido ao tipo de } \\
\text { contrato de trabalho; } \\
\text { - Não recolhimentos das verbas previdenciárias; } \\
\text { - "Compra" das férias; } \\
\text { - Não gozo das férias; } \\
\text { - "Calote" nas verbas rescisórias; } \\
\text { - Atraso de salários; } \\
\text { - Documentação dos trabalhadores; } \\
\text { - Metas inalcançáveis na jornada normal de trabalho; } \\
\text { "Violações quanto ao vínculo empregatício foram } \\
\text { contabilizadas no eixo Contrato individual de trabalho; } \\
\text { "Violações quanto à saúde do trabalhador foram } \\
\text { contabilizadas no eixo Saúde do trabalhador; } \\
\text { "Violações nos direitos sindicais foram contabilizados no } \\
\text { eixo "Ação coletiva e ação sindical"; }\end{array}$ \\
\hline - Não existência de treinamento; \\
- Treinamento "no pé da máquina"; \\
- Formação/treinamento segregado para homens e \\
mulheres; \\
- "Treinamento" de crianças; \\
- Problemas de qualidade e perda de produção devido \\
à falta de treinamento; \\
- Treinamento comportamental; \\
- Treinamento que não condiz com as atividades \\
realizadas; \\
- Fragmentação do conhecimento relativo à produção, \\
com a fragmentação da produção em unidades \\
fisicamente distantes; \\
- Falta de oportunidade e tempo livre para realização de \\
cursos de qualificação;
\end{tabular}




\begin{tabular}{|l|l|}
\hline Códigos & \multicolumn{1}{c|}{ Evidências } \\
\hline & $\begin{array}{l}\text { dos bairros periféricos; } \\
\text { - Dificuldades em manter contas básicas do orçamento } \\
\text { familiar, como educação e transportes; } \\
\text { - Necessidade de mais pessoas ocupadas para compor } \\
\text { o orçamento familiar; } \\
\text { - Precarização do trabalho e precarização social; } \\
\text { precarização da vida; } \\
\text { - Redução das horas de lazer por falta de recursos no } \\
\text { orçamento; } \\
\text { - Redução do tempo livre; } \\
\text { - Tempo livre das crianças utilizado para trabalho, para } \\
\text { compor a renda familiar; } \\
\text { - Necessidade de programas de transferência de renda } \\
\text { pela insuficiência da renda do trabalho; }\end{array}$ \\
\hline
\end{tabular}

Fonte: RBS - Balanço da produção acadêmica sobre condições e relações de trabalho dos terceirizados, 2019. Elaboração da autora.

Em relação às horas extras, os registros presentes nas teses e dissertações demonstram que é muito frequente a realização de jornada além da contratada e de forma habitual. O uso desse artifício procura evitar a contratação de mais trabalhadores, no entanto, é ilegal. A Lei estabelece um limite de horas extras de 2 horas/dia (CLT, art. 59). No entanto, a utilização desse acréscimo de forma permanente é proibida, pois nesse caso, significa que as empresas precisariam contratar um número maior de trabalhadores e trabalhadoras.

Em relato presente na dissertação de Sanches (2006), as jornadas de trabalho em uma determinada empresa terceirizada, que prestava serviços em atividades financeiras, chegavam a 10 ou 15 horas com frequência. Trabalhadores do transporte, em uma empresa de papel e celulose também relataram longas jornadas que chegavam a 18 horas (OLIVEIRA, 2014). Entre os trabalhadores terceirizados do setor naval, o relato indicava que a grande quantidade de horas trabalhadas os levava "a exaustão e a privação do convívio em família" (SILVA, 2016, p.124). Os relatos sobre os setores de confecção e calçados são unânimes em apontar a frequente realização de horas extra no período de alta da produção, incluindo também trabalho nos 
sábados e domingos (ALMEIDA 2008, AMORIM, 2003, VETURIM 2016, LIMA, 2009). Em estudo sobre a cadeia produtiva do setor automotivo foi destacado que quanto mais distante da empresa contratante, considerando a quarteirização das fases de produção ali presentes, maior era a utilização das horas extras de forma habitual (BARBOSA, 2013). Abaixo, dois trechos que demonstram a utilização das horas extras e a impossibilidade do trabalhador se contrapor às solicitações das empresas.

Trabalhadoras em empresa terceirizada do comércio varejista (comércio de roupas), Palhoça, SC:

A gente só tinha mesmo hora pra entrar. O horário de saída sempre era indefinido. Dependia da quantidade de trabalho. O mínimo que eu fazia era do meio dia até meia noite e meia, uma hora da manhã. Isso era de segunda à sexta. Isso quando a gente não virava a noite trabalhando. Aí só saía às cinco, seis horas da manhã. Fazer o quê? Eles chegavam pra gente e falavam que ninguém podia ir embora sem terminar o serviço. Era muita pressão! Se saísse eles anotavam o nome numa prancheta. Aí era demissão na certa (PEREIRA 2009, p. 86).

Trabalhadoras do asseio e conservação em uma universidade pública:

A negociação cotidiana não resolvia a questão da jornada de trabalho dessas mulheres, que ultrapassava as quarenta e quatro horas semanais. Além disso, como a maioria delas morava em regiões periféricas à cidade de Brasília, seus dias de trabalho dividiam-se, basicamente, entre os trajetos de ida e vinda do trabalho e o labor em si (CHAGAS, 2014, p. 56).

As teses e dissertações também destacam que além da ampliação da jornada de trabalho com o estabelecimento das horas extras, as empresas ampliam o ritmo de trabalho através de metas inalcançáveis e que colocam em risco a saúde do trabalhador, ou ainda, que são aceitas pelos trabalhadores e trabalhadoras devido às ameaças de demissão e assédio moral. As empresas também reduzem ou eliminam pausas de descanso e usam as tecnologias para eliminar os tempos mortos, intensificando a atividade laboral.

Trabalhadores terceirizados de empresa prestadora de serviço ou produtora de partes e peças para o setor automotivo, Sumaré, SP: 
O ritmo de trabalho e a pressão feita pelos chefes, para acelerar cada vez mais o processo são outros fatores apontados pelos trabalhadores e pelo sindicato dos metalúrgicos como causadores de doenças ocupacionais (MARCELINO, 2002, p. 170).

O trecho abaixo demonstra a diferença do volume de trabalho realizado pelas trabalhadoras e trabalhadores terceiros e pelos diretamente contratados pelos bancos:

Portanto, perfaz, um total estimado de 2.192 autenticações por dia contra 650 do bancário não terceirizado. Apesar da peculiaridade de cada um, é visível que os terceirizados se encontram mais expostos às tarefas repetitivas em um maior número de horas (SANCHES, 2006, p.86).

Ainda em relação ao ritmo de trabalho, destacamos as considerações escrita por Cavaignac (2010), sobre o uso das tecnologias como elemento para ampliar o ritmo de trabalho, no setor de teleatendimento:

As novas tecnologias de informação e comunicação, pautadas no uso de computadores, podem até simplificar o trabalho dos atendentes, mas não melhoram suas condições de trabalho nem sua qualidade de vida, aumentando, por exemplo, os tempos de pausa para descanso, alimentação, ginástica laboral, entre outros. Pelo contrário, essas tecnologias agem como mecanismos de intensificação do trabalho, bem como de controle e de vigilância dos trabalhadores, impondo-lhes a constante exigência de cumprir as metas de produtividade estabelecidas pela empresa em intervalos de tempo cada vez menores (CAVAIGNAC, 2010, p. 94).

No código Jornada de trabalho sistematizamos as situações em que as trabalhadoras e os trabalhadores terceirizados têm regulações sobre o tempo de trabalho distintas dos diretamente contratados. Isso ocorre porque os trabalhadores diretamente contratados estão empregados em setores que possuem legislação específica sobre como deve ser a jornada de trabalho nestes setores. As empresas que prestam serviços para setores com jornadas de trabalho especiais estão cadastradas com atividades econômicas distintas, que não precisam seguir estas regulações. Nos estudos, destaca-se o setor de atividades financeiras e da saúde, com jornadas de trabalho regulamentas para o máximo de 30 horas semanais, além de trabalhadores em setores com 
processo de produção ininterrupto, com jornadas de 36,36 horas semanais, em média.

Com a terceirização, as jornadas de trabalho reduzidas legalmente são burladas e os terceirizados, mesmo trabalhando lado a lado com os diretos, têm jornadas de 40 a 44 horas semanais, como destaca Pires (1996) em que "a jornada de 30h para os trabalhadores do hospital publico não é seguida pelos trabalhadores terceirizados dentro do hospital' (79:3). No setor petroquímico, no qual empresas classificadas como processo contínuo e portanto, que deveriam seguir a jornada de trabalho em turno ininterrupto de revezamento ${ }^{38}$, mantinham os trabalhadores terceirizados com jornadas de trabalho contratada maiores, mesmo que executassem sua atividades no interior da contratantes e que acompanhassem todos os turnos de trabalho (DRUCK, 1995). Abaixo, relato do setor de atividades financeiras, como demonstra Sanches (2006):

A jornada diária de trabalho se alterou, de modo significativo, com o processo de terceirização do setor de Retaguarda e Compensação. Houve um aumento diário de $46 \%$ na quantidade de horas contratuais, sendo de partida ampliada de 6 para 8 horas e 48 minutos no próprio contrato de trabalho assinado pelos terceirizados, que são registrados como efetivos nas empresas prestadoras de serviço. De acordo com os gestores destas empresas, o aumento da jornada diária de trabalho decorre, de um lado, pelo fato de não serem bancários, desobrigando-os de cumprir as 6 horas de trabalho por dia, conforme rege a CLT (Consolidação das Leis do Trabalho. Artigo 224); e de outro, os 48 minutos diários, trabalhados além das 8 horas diárias de jornada, são para compensar o trabalho aos sábados, pois esta atividade, na visão das empresas terceirizadas, se liga ao comércio (p.83).

Esse fato também foi verificado no setor automotivo, em que a jornada de trabalho de 40 horas semanais, instituída mediante negociação coletiva, foi burlada nas empresas terceirizadas. O estudo de Barbosa (2013) demonstrou que a jornada de trabalho de 40 horas semanais era realizada pelos trabalhadores diretamente contratados pela empresa-mãe (a Ford em Camaçari, BA) e por alguns sistemistas que nela trabalhavam. Para os demais trabalhadores (de empresas dentro da Ford ou para aqueles de outros níveis

\footnotetext{
${ }^{38}$ XIV - jornada de seis horas para o trabalho realizado em turnos ininterruptos de revezamento, salvo negociação coletiva. Art. 7ํ, Constituição Federal, 1988.
} 
de fornecimento na cadeia, fora da empresa) a jornada de trabalho era a máxima definida na constituição federal, de 44 horas semanais, mas chegando com frequência às 48 horas semanais.

Outro destaque no código Jornada de trabalho é o tema das horas de viagem entre a casa do trabalhador e o seu posto de trabalho. Parte das teses e dissertações relata que a distância percorrida diariamente para chegar ao trabalho e retornar para a casa, era considerada pelas trabalhadoras e pelos trabalhadores como penosa. Isso era ainda mais grave no caso daquelas empresas que não pagavam vale transporte: nesse caso, muitos trabalhadores realizavam trajetos a pé entre sua casa e o trabalho, para economizar. Um exemplo destacado foi o dos trabalhadores do comércio varejista, em Palhoça, SC, que caminhavam 4,5 quilômetros para chegar ao trabalho, e retornavam a fazer esse trajeto ao final do final do dia, depois de uma jornada extenuante (PEREIRA, 2009). Ou ainda, no relato abaixo, sobre a jornada diária de um trabalhador do setor de energia elétrica em Minas Gerais:

Está de pé desde as $5 \mathrm{~h}$ da manhã, como faz todos os dias quando tem que sair de casa e pegar o ônibus que sai às 5 h30 da manhã do ponto final, dois quarteirões abaixo da rua onde mora. Apesar de ter acordado no mesmo horário de costume, o senhor Raul não precisará percorrer hoje os mais de 25 quilômetros que separam a sua casa do local de trabalho - a sede da empreiteira -, localizada na Cidade Industrial, cidade de Contagem, região metropolitana de Belo Horizonte, de transporte público. Hoje vamos de carro. Os visitantes chegaram bem cedo porque vão acompanhá-lo durante todo o dia; desde a saída de sua casa, até o final da jornada de trabalho e o retorno para a residência, algo previsto para acontecer por volta das $19 \mathrm{~h} 30$ da noite (FIGUEIREDO, 2015, p.24).

Outra evidência que encontramos nas teses e dissertações sistematizadas é o da insuficiência de horas trabalhadas. Nesses casos, os trabalhadores são contratados para uma jornada inferior do que às 44 horas semanais - como o pagamento salarial é proporcional às horas trabalhadas, isso significa uma redução na remuneração e, portanto, dificuldades adicionais para a manutenção do orçamento familiar. No setor de confecção e calçados, a jornada reduzida (com salário reduzido) está relacionada aos períodos de baixa da produção e implementada de modo informal, sem negociação com sindicato 
da categoria, como prevê a Constituição Federal: os tributos sobre a folha de pagamento continuam sendo recolhidos, mas o pagamento das trabalhadoras e trabalhadores é realizado considerando apenas os dias efetivamente trabalhados (ALMEIDA, 2208, AMORIM, 2003, LIMA, 2009).

No caso do setor e asseio e conservação, Andreta (2016) destaca que as trabalhadoras contratadas para jornadas de trabalho de 30 horas semanais recebem menos do que um salário mínimo. A convenção coletiva de trabalho, que regulamenta as condições de trabalho dessas mulheres, não prevê o direito ao vale alimentação para essa jornada reduzida. Além das perdas financeiras, essas trabalhadoras reclamam que precisam intensificar o ritmo de trabalho para dar conta de todas as tarefas demandadas e a manutenção de uma jornada de trabalho reduzida. Caso semelhante é relatado por Campos (2009) em uma cooperativa de trabalho, no qual os trabalhadores de serviços gerais têm jornadas inferiores às 44 horas semanais e valores remuneratórios reduzidos proporcionalmente.

O Código Remuneração está entre um dos mais presentes em todas as teses e dissertações e as evidências englobam uma diversidade de situações negativas para os trabalhadores, ocasionadas pela terceirização: salários inferiores aos pagos para os trabalhadores diretamente contratados; insegurança salarial; não pagamento de salário direto ou indireto, entre outros, conforme demonstra o Quadro 8, na página 136.

Conforme lemos acima, o risco pelo negócio é de responsabilidade do empregador, mas em alguns processos de terceirização, esse risco é compartilhado com o trabalhador. Exemplo disso são os casos estudados no setor de calçados e confecção: as trabalhadoras e os trabalhadores têm salários reduzidos ou não pagos em período de baixa na produção, como dito acima. Em relação à remuneração também é recorrente os relatos de não pagamento de férias e $13^{\circ}$ salário, direitos assegurados na Constituição Federal (ALEMEIDA, 2008).

Outra característica dos trabalhos mais precários é o pagamento por produção. Além de elevar o ritmo de trabalho, pode resultar em salário menor do que o mínimo nacional (ALMEIDA, 2008; AMORIM, 2003; LIMA, 2009). No Brasil, também segundo as Leis trabalhistas, é preciso garantir um valor 
mínimo de salário, para somente depois, incluir adicionais a título de metas de produção, volume de vendas ou atendimento. Esse dispositivo remuneratório atrelado à produtividade é um dos elementos que precarizam os salários e impõem uma condição de insegurança para os trabalhadores, como apresentado por Almeida (2008):

Ademais, o pagamento por produção é um convite à maior produtividade $\mathrm{e}$ isenta os industriais da garantia do pagamento de salários nos períodos sem produção. Desse modo, a empresa adquire maior flexibilidade, pois numa queda qualquer de produção, não é preciso demitir funcionários internos, registrados, basta não mais requerer os serviços de suas subcontratadas, com as quais a seu ver não têm vínculos. Esse fator é extremamente vantajoso, no caso do setor calçadista, que tem uma alta sazonalidade, e a externalização dos trabalhadores torna mais flexível o fluxo de trabalhadores utilizados pela indústria (ALMEIDA, 2008, p. 85).

Também é relevante destacar que as trabalhadoras e os trabalhadores dos setores de confecção e calçado - fortemente impactados pela sazonalidade da produção e pela desregulamentação de seus postos de trabalho - são demitidos todos os anos na "entressafra" da produção e recontratados no próximo período, o que confere forte insegurança salarial aos orçamentos familiares (CRICO, 2006). Para sobreviver, as trabalhadoras e os trabalhadores precisam executar outras atividades nesse período de desemprego, que se configuram por atividades informais e pontuais (os "bicos"), além de recorrerem ao seguro desemprego ${ }^{39}$.

Outra evidência relatada nos estudo é a redução da remuneração devido à inexistência ou redução dos adicionais (seja de função ou de insalubridade e periculosidade), das gratificações e dos benefícios que se configuram como salário indireto, tais como vale alimentação ou refeição. Essa

\footnotetext{
${ }^{39}$ Esses trabalhadores fortemente precarizados, recorriam ao seguro desemprego anualmente, como fonte de renda nos períodos em que, sem produção, eram demitidos. Mas em 2015, as regras do seguro desemprego foram alteradas e o tempo de carência (número de meses formalmente empregado) para poder usufruir desse benefício foi aumentando: na primeira requisição, é necessário ter 12 meses de trabalho nos últimos 18 meses (antes eram 6 meses de trabalho nos últimos 12 meses); na segunda requisição, 9 meses de trabalho nos últimos 12 meses. Assim, as trabalhadoras e os trabalhadores conseguem acumular carência mínima necessária para solicitar o seguro desemprego a cada dois anos, um ano conseguem acionar 0 seguro desemprego, no outro não (MP 665/2014, transformada em Lei 13.134/2015).
} 
forma de precarização é relata Duque (2013), em sua pesquisa sobre a terceirização em um hospital universitário (Belém, PA):

Além da diferença salarial, também foi mencionado os plantões extras, em referência ao $\mathrm{APH}$, que é realizado somente por servidores, enquanto os fundacionais, que também realizam plantão, não tem direito ao recebimento do adicional (DUQUE, 2013, p.73).

E ainda, em Teixeira (2013), que estudou a terceirização nos Correios:

Os profissionais terceirizados não recebem os mesmos salários que os funcionários da ECT e não são contemplados pelos benefícios garantidos aos ecetistas nos acordos coletivos - assistência médica, previdência privada etc. -, o que já reduz significativamente os custos da folha de pagamentos da empresa pública (p.203).

Outra evidência citada é a que se refere ao pagamento menor para a trabalhadora ou trabalhador terceirizado quando comparado com o trabalhador diretamente contratado pela empresa-mãe, inclusive em funções semelhantes. Mesmo quando não se comparam funções semelhantes à regra é o rebaixamento generalizado dos salários médios dos terceirizados em relação aos salário dos trabalhadores diretos (ANDRETA, 2016; BARBOSA, 2013; DIAS, 1998; SANTOS, 2009; CARVALHO, 2008; MARCELINO, 2002; OLIVEIRA, 2008; RIOS, 2007; SANCHES, 2006; BABORSA, 2010; DIAS, 2008; DRUCK, 1995). Para ilustrar, segue alguns relatos das diferenças salariais entre terceirizados e diretamente contratados.

Trabalhadores da cadeia de fornecimento no setor automotivo, Camaçari, BA:

Quando se observa as condições salariais ao longo da cadeia, percebe-se sua deterioração à medida que se encaminha para os níveis inferiores. Se a metade $(49,9 \%)$ dos funcionários da montadora (nível zero) tem uma remuneração de quatro salários mínimos ou mais, na cadeia de subcontratação essa participação se reduz para $27,9 \%$ nas sistemistas (1ำ nível), $16,6 \%$ nas fornecedoras de autopeças (2o nível) e 12\% nas fornecedoras de componentes (3ำ nível) (BARBOSA, 2013, p.166 ).

Trabalhadores em atividades financeiras, Goiás: 
Salários - Enquanto o Banco Oficial paga em torno de 4,3 salários (salário $R \$ 850,00+$ benefícios $R \$ 450,00$ ) ao seu funcionário em início de carreira - é importante frisar que se refere ao menor salário pago a um bancário -; as empresas " $A$ " e "B", que contabilizam uma pequena diferença de remuneração, pagam menos que 2 salários aos terceirizados (CARVALHO, 2006, p.87).

Trabalhadores no setor de serviços, Salvador, BA:

A maioria dos trabalhadores pesquisados ganha até $R \$ 800,00$ por mês $(57,7 \%)$, porém a distribuição indica diferenças expressivas entre os dois grupos. Muito embora os terceirizados e não-terceirizados da amostra exerçam as mesmas funções dentro da organização, a recompensa financeira dos terceirizados é significativamente mais baixa, podendo se observar a concentração nos níveis mais baixos de renda (RIOS, 2007, p. 62-63).

Trabalhadores no setor de alumínio, Barcarena, PA:

No que diz respeito aos rendimentos, os terceirizados entrevistados que trabalham nas áreas de redução e fundição revelaram ganhar entre $R \$ 600,00$ e $R \$ 850,00$. Já os trabalhadores diretos ganham, em média, $\mathrm{R} \$ 1.500,00$ (BARBOSA, 2015, p.116).

Trabalhadores no setor petroquímico, Mossoró, RN:

No tocante à remuneração, o salário médio dos empregados das contratadas não ultrapassa os $R \$ 700,00$, valor este bem inferior aos $\mathrm{R} \$ 2.814,00$ que é percebido pelo trabalhador efetivo da Petrobras. Um estagiário da Petrobras recebe como remuneração a quantia mensal de aproximadamente $\mathrm{R} \$ 500,00$ (SOBRINHO, 2006, p. 227).

Nesse caso, também há relatos de processos de terceirização promovidos pelas empresas contratantes que resultaram na realocação de seus trabalhadores diretos para o quadro funcional da empresa terceirizada, com salários menores (BARBOSA, 2015) "(...) todos os que trabalham como terceirizados hoje foram funcionários da Albrás. Ela contrata de novo o mesmo cara pagando menos" (p. 65). Nesse mesmo sentido, o relato abaixo, em um estudo sobre uma indústria química terceirizada, em Curitiba, PR, que foi criada com o estímulo da empresa contratante, com a transferência de trabalhadores do quadro próprio para o prestador de serviços terceirizado: 
Dos funcionários que vieram [da empresa-mãe] com a terceirização apenas três continuaram. Todos declararam que tiveram os vencimentos rebaixados no novo contrato com a terceirizada (DIAS, 1998, p.97).

Encontramos um relato no qual o sindicato das trabalhadoras e trabalhadores em confecção, em Criciúma, SC, que representava tanto os trabalhadores diretos das empresas como os terceirizados, sofria pressão do setor empresarial local para implantar, através de negociação coletiva, pisos salariais distintos para as empresas (tomadoras, mas que também mantinham produção) e para as facções (que produziam para as grandes empresas locais). O sindicato mantinha a posição de que se tratava do mesmo trabalho e, portanto, não havia justificativa para tal mudança. No entanto, como afirmou o sindicato, muitas empresas estavam migrando para outra região (norte do Paraná), em busca de salários menores para as costureiras (local em que era pago valores próximos a um salário mínimo) (CALEFFI, 2008).

Por fim, um dos pontos relacionados à remuneração são os pedidos dos trabalhadores para se manterem na informalidade, incorporando valores relativos ao FGTS e à previdência em seu salário, aumentando o valor liquido recebido (ALMEIDA, 2008). Essa é uma forma encontrada pelas trabalhadoras e trabalhadores para elevar seus rendimentos. Essa saída é descrita pelos empregadores como uma "ajuda para os trabalhadores", mas na verdade, é mais uma forma de ampliar a precarização das condições de trabalho: os empregadores, claro, também se beneficiam porque deixam de recolher impostos que incidem sobre a folha de pagamentos. Para os trabalhadores resta a insegurança, pois estão fora da cobertura previdenciária:

Quase todos os funcionários são registrados, com exceção de alguns que pedem para não serem registrados, pois os descontos no seu salário que vão para FGTS, para a previdência, são somados aos seus vencimentos mensais, o que lhes dá a impressão de estarem recebendo mais (ALMEIDA, 2008, p. 130).

Ainda que de forma isolada, encontramos dois relatos de ações sindicais, que resultaram em medidas de redução das disparidades salariais entre trabalhadores terceirizados e diretos. Marcelino (2008) relata que em 2005, o sindicato que representava parte dos trabalhadores terceirizados da Replan 
(Campinas, SP), o Sinticom, iniciou um processo para igualar os salários dos trabalhadores que exerciam a mesma função nas diferentes empresas subcontratadas. Apesar de não ter sido registrado em acordo coletivo com as empresas, segundo relato dos sindicalistas, $70 \%$ das empresas subcontratadas atuantes no polo respeitavam essa regra. Nesse caso, o acordo não incluía a empresa contratante, a Replan, e embora não atingisse a "terceirização na sua raiz, nas suas consequências e nos seus objetivos fundamentais, conquistar essa isonomia é um fator importante de fortalecimento da luta dos trabalhadores" (p. 199).

Outro caso relatado foi à ação desenvolvida pelo STIMMMERG (Sindicato dos Trabalhadores das Indústrias Metalúrgicas e de Material Elétrico de Rio Grande e São José do Norte, RS), que mapeou as atividades dos trabalhadores no polo naval e elaborou uma tabela de referência para funções e respectivos salários. Apesar de não ser obrigatória, a tabela foi protocolada no Ministério do Trabalho e o sindicato utiliza esse instrumento para reforçar, junto às empresas do polo naval, a necessidade de cumprir aquele mínimo previsto (SILVA, 2016).

Apesar de importante, essas ações têm ocorrido de forma pontual, e como dito por Marcelino (2008) não revertem a precarização da terceirização de forma definitiva.

Em resumo, em relação à Remuneração, como diz Druck (1995), a terceirização fragmenta os trabalhadores: de um lado, um grupo reduzido de trabalhadores "inseridos" que conquistam ganhos por produtividade, participação nos lucros e outra formas de remuneração flexibilizada e de outro, aqueles que estão excluídos, inclusive do mínimo para seu sustento e de sua família. Segundo a autora "Para o capital, trata-se de um ótimo negócio: "dividem" menos e com menos "parceiros"' (p. 215). No mesmo sentido, Dias (2011) considera que essa situação - em que os trabalhadores ocupam postos de trabalho, no mesmo ambiente de trabalho, ao longo de anos, em condições tão distintas e contraditórias, com distinções criadas pelos capital - o resultado e que se "cria um fosso real entre eles, inclusive os colocando em situação de oposição" (p. 191). 
Em relação ao código Benefícios, apesar de aparecer com frequência, faltaram elementos nas teses e dissertações para detalhar as formas como a diferenciação entre terceirizados e diretos se dava efetivamente. De todo modo, encontramos relatos da não existência de benefícios para os terceirizados. Além disso, há uma frequência considerável de situações em que, apesar da existência dos benefícios mais recorrentes (plano de saúde, vale alimentação, vale refeição, cesta básica, vale transporte), eles eram em valor inferior, de menor qualidade e com menor variedade, quando comparados com as trabalhadoras e trabalhadores diretamente contratados pelas empresas tomadoras. Abaixo, trechos que ilustram a precarização das condições de trabalho através da piora dos benefícios para as trabalhadoras e trabalhadores terceirizados.

Trabalhadores terceirizados na RLAM, Petrobras, São Francisco do conde, BA:

(...) previdência privada, plano de saúde de qualidade, altos salários, dentre outros. Contudo, a mesma lógica não parece se aplicar aqueles trabalhadores que "prestam serviço" para a Companhia (BRITO, 2014, p. 130).

Trabalhadores em empresas prestadoras de serviço no setor de energia elétrica, Minas Gerais:

Na empresa há oito meses, o eletricitário admite que este trabalho não era bem o que ele esperava para o seu primeiro emprego como adulto. Sem ter direito aos mesmos benefícios que os trabalhadores contratados diretamente pela Cemig - tais como vale alimentação, participação nos lucros e remuneração (PLR), convênio médico, maior estabilidade e garantia do emprego, dentre outros -, o jovem já é capaz de elaborar reflexões interessantes sobre a diferenciação entre trabalhadores que exercem a mesma função, trabalhando para a mesma empresa, mas que não têm os mesmos direitos. Fábio critica essa discriminação e fragmentação que a terceirização provoca entre os trabalhadores a partir da realidade em que se encontra (FIGUEIREDO, 2015, p. 45).

Trabalhadores da indústria química, Camaçari, BA:

Quando interrogadas sobre a concessão de benefícios, 31\% das empresas declararam não conceder nenhum além das obrigatórias por Lei e $69 \%$ afirmaram que os concedem. 
Trata-se de um quadro bastante diferente daquele apresentado pela empresas contratantes que, na sua totalidade, informaram conceder uma série de benefícios previsto em Lei. Os benefícios mais concedidos são: assistência médica, indicada por $88 \%$; convênios com estabelecimentos comerciais (46\%) e cesta básica (25\%). Todos os benefícios são concedidos aos trabalhadores do quadro fixo, não sendo estendidos aos temporários e prestadores de serviço... (DRUCK, 1995, p. 200).

O código "Rotatividade e tempo de serviço" tem como conteúdos destacados nas teses e dissertações a demissão e recontratação dos trabalhadores segundo a sazonalidade da produção ou do contrato por obra. Também está nesse código a relação entre a rotatividade e o curto tempo médio de emprego dos terceirizados, resultado do "descarte" de trabalhadores adoecidos em função da atividade laboral. Há também relato de demissão para não acumular um valor considerado muito alto de verbas rescisórias. Segue os relatos.

Trabalhadores em empresas fornecedoras do setor automotivo, Camaçari, BA:

Do mesmo modo, o tempo que o trabalhador permanece no emprego revela condições desfavoráveis entre aqueles que se encontram subcontratados pelas empresas de $1^{\circ}$, $2^{0}$ e $3^{\circ}$ níveis. De imediato, chama a atenção que no terceiro nível $16,7 \%$ dos trabalhadores permanece no emprego, pasmem, por apenas três meses, $9 \%$ continua empregado entre três e seis meses, $22,2 \%$ fica no emprego entre seis meses e um ano e $13,2 \%$ de um a dois anos. (...) Por outro lado, enquanto dois terços (66,7\%) dos funcionários da montadora têm relativa estabilidade empregatícia (permanecem no emprego por 5 anos ou mais), entre os trabalhadores subcontratados, essa estabilidade fica restrita a 30,9\% (1ํㅡível), 21,4\% (2onivel) e 15\% no 3o nível (BARBOSA, 2013, p.167).

Trabalhadores terceirizados da Petrobras, Mossoró, RN:

A comparação do tempo de serviço entre os trabalhadores efetivos e os da empresa de terceirização não pode ser cotejada numa mesma escala temporal. Enquanto em relação aos efetivos é mais frequente falar-se em quinquênios ou decênios, em relação aos terceirizados 0 tempo de vida contratual é algo que perdura por meses ou por poucos anos (SOBRINHO, 2006, p. 225). 
Trabalhadores na confecção, Criciúma, SC:

Em nossa pesquisa constatamos que o trabalho nas facções é formal, mas instável devido à sazonalidade e aos imperativos da conjuntura econômica (CALEFFI, 2008, p. 48).

Trabalhadores do setor de calçados, Franca, SP:

Os funcionários possuem pouco tempo de permanência no emprego, pois são demitidos de dois em dois anos, "Eu procuro assim, quem está com dois anos a gente vai acertando, para não juntar muito. As férias também pagando e contrata outro." (ALMEIDA, 2008, p. 131).

Trabalhadores no setor de calçados, Franca, SP:

A demissão e o recebimento do seguro desemprego tornaram-se duas das alternativas que estão postas nos dias atuais (CRICO, 2006, p. 46).

Trabalhadores no setor de teleatendimento, Curitiba, PR:

O tempo médio na função dos trabalhadores pesquisados que realizam tal atividade é de 18 meses. Tal evidência demonstra que existe uma espécie de tempo útil para esse trabalhador (MENDES, 2005, p. 59).

Por fim, nesse código, registramos também as ocorrências em que, apesar do tempo de emprego na tomadora ser relativamente alto, há uma frequente troca de contratos, seja porque o contrato de prestação de serviços termina e uma nova empresa assume, seja devido à falência da empresa prestadora de serviços e o abandono do contrato.

Trabalhadores em atividades financeiras, Goiás:

Quanto aos digitadores, são contratados por tempo indeterminado pelas empresas " $A$ " e "B", porém essas empresas assinam contratos de um a dois anos com 0 banco. Isso se reverte na prática em situações onde os trabalhadores têm que se submeter a um processo de demissão/recontratação de tempos em tempos para que possam continuar trabalhando no banco, por meio de outra empresa contratada (CARVALHO, 2006, p. 88).

Trabalhadores no setor de energia elétrica, Minas Gerais:

Roberto fala que já passou por sete empresas diferentes, algumas ele soube que eram dos mesmos donos das 
anteriores em que trabalhou, mas que, por algum motivo, acabaram falindo e reabrindo depois, em outras cidades, com outro Cadastro Nacional de Pessoa Jurídica (CNPJ). (...) A vida laboral do eletricitário ao longo desses dezoito anos se resume a demissões e readmissões em empresas muito parecidas umas com as outras, seja pelo ramo de atividade, função para a qual ele é contratado ou ainda pela forma em que se demitem os funcionários ou declaram falência: "sempre querendo roubar o trabalhador", (Roberto Souza, eletricista, 39) (FIGUEIREDO, 2015, p. 47).

Trabalhadores no setor de asseio e conservação e serviços em uma instituição do ensino superior, Cruz das almas, BA:

Bezerra durante os 5 anos de serviços prestados a UFRB trabalhou em duas empresas interpostas. A HKS, por 3 anos e 4 meses, esta empresa saiu em uma disputa licitatória. E a SAVANA, a atual empresa que tem pouco mais de 1 ano e meio (SANTOS, 2014, p. 76).

Como veremos com mais detalhes no eixo Ação coletiva e sindical, na próxima seção, a rotatividade também interfere negativamente na organização dos trabalhadores, devido a frequente demissão dos trabalhadores e a perda de vínculos com aquela categoria (MARCELINO, 2008).

Além do rebaixamento generalizado das condições de trabalho, a terceirização também promove a redução de custos com a violação sistemática de direitos. No código Violação dos direitos que agora iremos relatar, não incluímos as violações relativas ao vínculo empregatício (que foram contabilizadas no eixo Contrato individual de trabalho), nem as violações quanto à saúde do trabalhador (que foram relatadas no eixo Saúde do trabalhador) e nem as relativas ao direito sindicato (que foram descritas no eixo Ação coletiva e ação sindical).

Um dado apresentado por Sobrinho (2006) releva como a terceirização é o instrumento privilegiado para a redução do custo do trabalho através da violação de direitos: em pesquisa sobre os processos trabalhistas que tinham a Petrobras como reclamada, $82,28 \%$ eram ações movidas por empregados das empresas terceirizadas. Em mais de $80 \%$ dos casos, as empresas deviam verbas rescisórias, como aviso prévio, FGTS e sua respectiva multa de $40 \%$, férias e $13^{\circ}$ salário. Como afirma Sobrinho "A inadimplência, nesse caso, é 
uma forma de a empresa apropriar-se, provisória ou definitivamente, daquilo que originariamente deveria ser destinado para remunerar o trabalho despendido pelo empregado" (p. 196). Isso evidencia que, diferente do discurso, a Petrobras não fiscaliza com o devido cuidado o cumprimento das normas trabalhistas.

Ou seja, mesmo as empresas terceirizadas que contratam formalmente seus trabalhadores utilizam de modo recorrente violações aos direitos trabalhistas. No setor de confecção, como relatado por Almeida (2008), em relação a uma banca (pequena empresa de confecção) os direitos associados à carteira de trabalho não são respeitados: não são pagas as 40 horas semanais trabalhadas, nem férias e $13^{\circ}$ salário. E complementa: " $A$ maioria das pequenas e médias bancas funcionam desse modo, existe um registro trabalhista que é somente formal, no papel, mas na prática os termos da relação são definidos no corpo a corpo entre patrão e empregado" (ALMEIDA, 2008 , p. 194). O registro é apenas uma formalidade exigida pelas empresas contratantes, para evitar problemas com fiscalização e responsabilidade subsidiária.

Segundo relato de um auditor fiscal do trabalho na cidade de Rio Grande, RS, as violações no polo naval nas diferentes empresas terceirizadas eram recorrentes, desde atraso no pagamento de salários e do não recolhimento do FGTS, mas também houve casos da falta do pagamento do vale-alimentação e até o não pagamento da conta de luz do alojamento dos trabalhadores terceirizados (SILVA, 2016).

Há também descumprimentos relativos à jornada de trabalho. Segundo o sindicato das trabalhadoras e trabalhadores em confecção, a concepção dos empresários é de que eles não podem utilizar a mão de obra contratada para trabalhar aos domingos, mas uma pequena empresa, de caráter familiar, não teria esse problema (SILVA, 2016, p. 84). Um exemplo de como a terceirização e a quarteirização facilitam as violações de direitos relativas à jornada de trabalho é o relato feito por Chagas (2014) sobre os constantes atrasos no pagamento dos salários, da retirada dos tíquetes alimentação e refeição e a não entrega do contrato de trabalho para trabalhadoras e trabalhadores do asseio e conservação em um órgão público federal, no Distrito Federal. 
Além do não pagamento ou atraso da remuneração direta e indireta, das verbas previdenciárias e das verbas rescisórias, também há relato de descontos indevido realizados pelas empresas. Por exemplo, em uma facção do setor de confecção em Cianote, PR, os valores relativos aos gastos de aluguel, conta de luz, água e dos custos gerados com a manutenção das máquinas eram divididos entre todas as funcionárias (LIMA, 2009).

Em relação às férias, encontramos dois tipos de violação, além do não pagamento do valor monetário previsto na Constituição e já comentado acima: primeiro, a impossibilidade de gozo do período de férias, devido as frequentes trocas de empresas, seja porque faliram, seja porque foram substituídas ao término do contrato com empresa tomadora Nesses casos, os trabalhadores poderiam até receber o valor das férias, mas não poderiam utilizar o tempo de descanso de 30 dias. Segundo Barros (2015), em sua pesquisa, havia trabalhadoras com quatro anos de prestação de serviços terceirizados em escola pública de São Paulo, sem terem usufruído o direito de férias. O segundo mecanismo de violação é que as empresas aceitam "comprar" as férias dos trabalhadores que nesse caso, ficam sem o período para descanso (CARVALHO, 2006).

No código Violação de direitos, temos também com frequência o "calote", no qual as empresas encerram suas atividades, não rescindem o contrato de trabalho e não realizam o pagamento das verbas rescisórias as quais os trabalhadores teriam direitos.

Abaixo, exemplos de calotes contra os trabalhadores e as trabalhadoras em diversos setores.

Trabalhadores do setor petroquímico, São Francisco do Conde, BA:

(..) após vencida a licitação, a empresa ganhadora tende a quarteirizar os seus serviços para tentar alcançar o cumprimento, ou simplesmente ela encerra o contrato sem a realização do serviço, pois os custos do mesmo não foram passíveis de serem cumpridas com a verba estipulada no contrato pós-licitação. A isso denomina-se, nativamente, de "quebradeira das empresas" ou "calote (BRITO, 2014, p. 133-134). 
Trabalhadores do setor de asseio e conservação e serviços, no ensino superior, Cruz das Almas, BA:

A primeira empresa que trabalhou prestando serviço a UFRB foi a LOCRHON, ficou por 1 ano e 3 meses. Depois veio a RP AMBIENTAL, nessa ficou por 8 meses. A RP AMBIENTAL deixa de pagar os salários dos funcionários e outros direitos: "Já entrou atrasando salário, não pagava tudo. Teve muitas pessoas que não recebeu vale transporte. Eu fui uma delas não recebi durante 8 meses vale transporte. A universidade assumiu os salários até fazer acordo". Depois desse episódio a LOCRHON assina novamente contrato com a UFRB e está até o dia de hoje, o dia da entrevista (SANTOS, 2014, 73-74).

Por fim, registramos dois relatos de violação de direitos que ultrapassam o direito do trabalho, e se aproximam do cárcere privado. Trabalhadores do comércio varejista, Palhoça, SC:

Os relatos dos trabalhadores dão conta de que, em algumas oportunidades, a fim de garantir o cumprimento de metas, os portões da empresa eram fechados e os trabalhadores impedidos de sair até que o serviço fosse concluído exacerbando a extração da mais valia (PEREIRA, 2009, p.90).

Trabalhadores em atividades financeiras, São Paulo, SP:

Nos casos em que os terceirizados ficavam retidos dentro da empresa, o Sindicato chegava a registrar Boletim de Ocorrência na Delegacia Regional do Trabalho, acusando as empresas de manter trabalhadores sob cárcere privado. A alegação era de que suas jornadas regulamentares já haviam sido cumpridas e havia impedimento das empresas para estes saírem devido à paralisação, 0 que os obrigava a trabalhar ininterruptamente por mais de 20 horas (SANCHES, 2006, p. 108).

O código Treinamento e formação profissional tem como ocorrência mais frequente a falta de treinamento para execução das atividades laborais. Mas outro elemento, apresentado por Almeida (2008), sobre o setor de calçados é que o treinamento se dá diretamente na produção, liberando a indústria de ter que realizar esse investimento.

As pesquisas destacam que o treinamento ocorre "no pé da máquina", com as dicas ensinadas pelos demais trabalhadores e trabalhadoras. Há 
também registros de formação segregada para homens e mulheres, no setor de confecção e calçados: há ocupações tipicamente femininas e outras, tipicamente masculinas, e o treinamento realizado durante o processo de trabalho reforçava essa segmentação. Também há registros de trabalho não pago ou pago parcialmente, a título de treinamento, seja para adultos, homens e mulheres, mas também para crianças, sob a justificativa de estar propiciando a formação de uma profissão.

Trabalhadoras no asseio e conservação em Santa Maria, RS:

Nenhuma das participantes dessa pesquisa recebeu treinamento formal, por parte das empresas de terceirização de serviços, sobre como usar adequadamente os equipamentos de proteção individual que the são fornecidos. Não havendo treinamento formal, as orientações são dadas de diferentes formas (ou mesmo não são dadas) ainda que dentro de uma mesma empresa de terceirização de serviços (ANDRETA, 2016, p. 174).

Trabalhadores terceirizados da Petrobras, São Francisco do Conde, BA:

Desta forma, observa-se que com o processo de externalização há um processo conjugado e simultâneo de desresponsabilização sobre aquele que deve ser o responsável pelo treinamento, que com a institucionalização da terceirização na Petrobras passou desta para as empresas terceirizadas, e que agora vem gradualmente sendo repassada aos próprios trabalhadores terceirizados (BRITO, 2014, p. 215).

Trabalhadores em atividades financeiras, Goiás:

As empresas "A" e "B" não promovem nem sequer um treinamento inicial para os prestadores de serviço que, em tese, deveriam ser especializados no que fazem; pelo contrário, mais uma vez evidencia-se a contradição do processo: quem realiza 0 treinamento desses terceirizados é o próprio banco que, diga-se de passagem, geralmente realiza um mero training on job (CARVALHO, 2006, p.88).

Trabalhadores no setor de calçados, Franca, SP:

Como a entrevistada não tem experiência no ramo, sendo esse o seu primeiro emprego no setor, o patrão lhe paga a quantia mensal de 200 reais, alegando que ela não atinge a produção desejada, colocando-a na categoria de 
aprendiz, embora ela cumpra o mesmo horário que o restante das funcionárias (ALMEIDA, 2008, p.199).

Sem o treinamento adequado, encontramos registros de problemas de falta de qualidade ou perdas na produção relacionados à falta de treinamento dos trabalhadores e trabalhadoras. Apesar das justificativas empresariais para a terceirização se pautar em argumentos de que o processo permite ganhos de qualidade e produtividade com a especialização das empresas, essa faceta das condições de trabalho - a falta de treinamento - evidencia uma contradição entre a qualidade e o treinamento fornecido pelas empresas para os trabalhadores. Abaixo, dois relatos de como a falta de treinamento atinge a qualidade da produção e dos serviços e de que, apesar de ser de responsabilidade do empregador, há uma tentativa de responsabilizar os trabalhadores e trabalhadoras pelos problemas da produção/atendimento.

Trabalhadoras do asseio e conservação na educação pública, Distrito Federal:

Os supervisores reclamaram muito desse quesito, informaram que muitos terceirizados não sabem usar os equipamentos, como bota, luvas, máquinas etc. e que não estão preparados para usar a quantidade correta de detergente, desinfetante, cera etc., além de que não há preparo para contenção de gastos para água ou energia e que não foi ofertado pela empresa 0 curso para esses terceirizados (BARROS, 2016, p. 66).

Trabalhadores em atividades financeiras, São Paulo, SP:

O treinamento inexiste e, conforme relato do trabalhador, este é um dos motivos geradores dos diversos erros no processo de trabalho: O funcionário erra, mas não por culpa dele. O funcionário não passa por treinamento, passa por uma coerção, muito grande, com ameaças... (SANCHES, 2006, p. 87).

Por outro lado, o relatado de casos onde há treinamento, nas teses e dissertações analisadas, indica um forte conteúdo comportamental. Por fim, há também o registro de como os trabalhadores estão convencidos de que sua situação de vulnerabilidade está ligada a sua baixa escolaridade e formação profissional. As reclamações desses trabalhadores indicam também a 
impossibilidade de ampliar a qualificação em razão do pouco tempo livre e do cansaço extremo a que estão submetidos.

Trabalhadores da indústria química, Curitiba, PR:

"Se tivesse estudado mais não estava nessa", é a afirmação mais utilizada para reclamarem das péssimas condições de trabalho que estão vinculados e da pouca escolaridade (DIAS, 1998, p. 91).

Quanto ao código Condições de vida, apesar de poucas pesquisas apresentarem dados e informações primárias sobre os aspectos relacionados ao modo de vida dos trabalhadores e trabalhadoras terceirizadas, as teses e dissertações que trouxeram essas informações relataram uma precarização da vida do trabalhador e de sua família.

Dentre as principais questões que puderam ser sistematizadas, estão aquelas relacionadas às restrições orçamentárias, fruto de uma remuneração rebaixada. Em decorrência de salários que não são suficientes para o sustento de suas famílias há relatos sobre a dificuldade em manter os filhos na escola e também sobre o peso do gasto com transporte no orçamento familiar (CASTRO, 2005; CHAGAS, 2014). Também em decorrência dos limites orçamentários há limites para o lazer e a formação profissional. Como os salários são insuficientes, há trabalhadores que declararam ser beneficiários de programas de transferência de renda (Programa Bolsa Família ${ }^{40}$ ) (BARROS, 2015). Para ampliar o orçamento familiar outras pessoas da família precisam trabalhar e como já listado acima, inclusive as crianças (CASTRO, 2005).

Nas teses e dissertações que apresentaram informações sobre o tema, também foi recorrente questões relativas à habitação. Os trabalhadores terceirizados vivem em casas cedidas ou em anexos da casa de parentes e amigos (ANDRETA, 2016; COSTA, 2016). Há relatos de que os terceirizados residem em bairros com maior vulnerabilidade social do que os bairros operários habitados pelos que estão incluídos na sociedade salarial ${ }^{41}$

${ }^{40} \mathrm{O}$ Programa Bolsa Família é um programa que contribui para o combate à pobreza e à desigualdade no Brasil. Ele foi criado em outubro de 2003 e possui três eixos principais: complemento de renda; acesso a direitos; e articulação com outras ações. Disponível em: http://mds.gov.br/assuntos/bolsa-familia/o-que-e

${ }^{41}$ Castel, 1999, A SOCIEDADE SALARIAL - In: As metamorfoses da questão social: uma crônica do salário. 
(CASTRO, 2005; ROSSETI, 1996; CHAGAS, 2014). Em duas dissertações há informações também sobre a qualidade das habitações: uma das dissertações demonstra uma diferença no padrão de casas dos operários tradicionais da indústria de Limeira, SP, comparativamente ao padrão de pior qualidade das residências dos trabalhadores terceirizados dessa mesma indústria (ROSSETTI, 1996); na outra além do relato sobre as diferenças entre os bairros $e$ as habitações onde residem os trabalhadores diretos e os terceirizados, há também relatos sobre a participação dos trabalhadores terceirizados nos movimentos de luta por moradia em São José dos Campos, SP (CASTRO, 2005) e de trabalhadores do setor de alumínio, em Barcarena, PA, que moram em ocupações (BARBOSA, 2010).

Os momentos de lazer, formação e de descanso também são mais limitados devido às jornadas flexíveis e extensas, ou ainda, devido à necessidade de ter mais de uma ocupação para compor a renda (JUNIOR, 2007; OLIVEIRA, 2008; SCAVICHIA, 2015). Até mesmo o tempo livre das crianças é reduzido, dentre aquelas que trabalham (SOUZA, 2005).

No Gráfico 2, página 118, podemos observar de forma sintética o resultado da sistematização dos indicadores de precarização da terceirização (códigos) que constituem o eixo Condições de trabalho. Das 67 teses e dissertações objeto de análise a partir da Revisão Bibliográfica Sistemática (RBS), 61 possuíam informações de um ou mais códigos do presente eixo. A análise do código "Horas extra" teve como base 24 documentos; o código Ritmo de trabalho contou com 15 documentos; Remuneração incluiu 51 pesquisas para essa análise; o código Benefícios foi avaliado a partir de 28 teses e dissertações; o código "Rotatividade e tempo de emprego" contou com 39 pesquisas; o código Violação dos direitos abrangeu 26 teses e dissertações e por fim, "Treinamento e formação profissional" foi investigado em um universo de 28 documentos.

Em termos percentuais (conforme gráfico 8, página 118), nos 67 documentos analisados nesse eixo 68,7\% apresentaram condições precárias quanto ao contrato de trabalho, outros $17,1 \%$ apresentaram problemas em partes, ou seja, apesar do tipo de contrato ter algum efeito negativo, não acomete todos os trabalhadores terceirizados. Segundo a análise, em 11,5\% 
dos casos investigados não há precarização dos terceirizados através das condições de trabalho. Em 2,8\% (6 teses e dissertações) das teses e dissertações não havia informações disponíveis na pesquisa de campo sobre os códigos desse eixo.

Conforme a Tabela 8, na página 119, podemos analisar de forma desagregada os códigos que compõem esse eixo. As maiores evidências de precarização são aqueles relacionados a problemas na Remuneração, principalmente redução em relação aos diretamente contratados e não pagamento; seguidos dos problemas relacionados à alta Rotatividade e baixo tempo de serviço e falta de treinamento ou treinamento sem qualidade conteúdo necessários para execução das atividades laborais. Em relação aos benefícios, há uma frequência relevante de empresas terceirizadas que fornece os itens mais comuns como transporte, vale refeição e plano de saúde, apesar de problemas relatados, ligados à qualidade e valor.

O eixo Condições de trabalho é o mais frequente dentre os eixos sistematizados ao longo da pesquisa. Chama atenção que o principal tema presente nas teses e dissertações seja justamente a remuneração e a rotatividade/tempo de emprego dos terceirizados. A remuneração é fator central para a redução dos custos do trabalho, e como foi descrito nos exemplos acima citados, a terceirização é uma ferramenta bastante relevante nessa estratégia patronal. A rotatividade e o tempo médio de empresa reduzido, além de promover $\mathrm{o}$ achatamento dos salários, porque os trabalhadores não incorporam reajustes e aumentos reais, utiliza a mão de obra como uma mercadoria qualquer, um insumo para a produção, comprado na quantidade necessária para um determinado período, logo depois, descartada. 


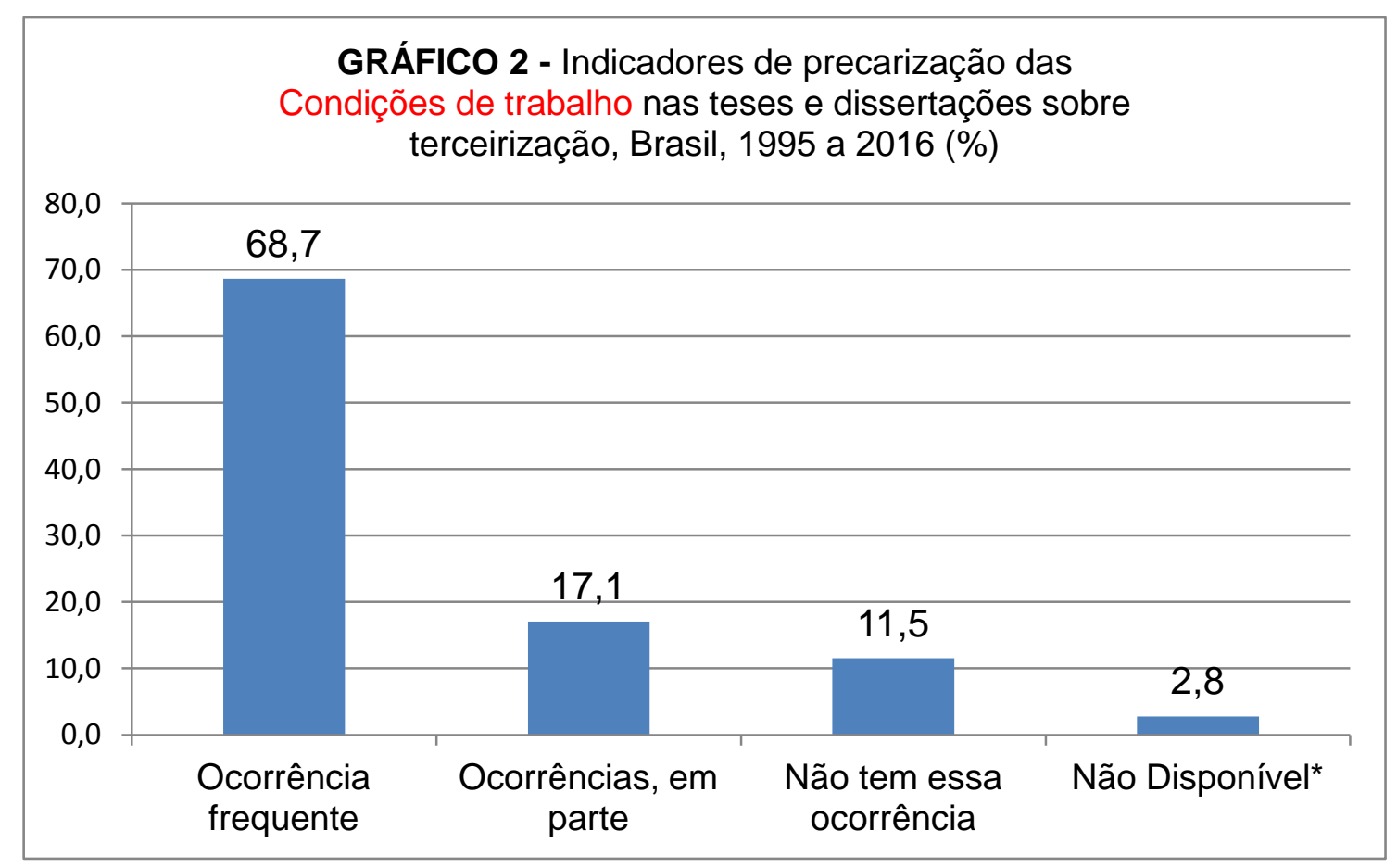

Fonte: RBS - Balanço da produção acadêmica sobre condições e relações de trabalho dos terceirizados, 2019. Elaboração da autora. *Não disponível: nas teses e dissertações estudadas esse tema não foi objeto de investigação na pesquisa de campo. 
TABELA 8 - Frequência dos indicadores de precarização do trabalho do eixo Condições de trabalho, presentes nas teses e dissertações sobre terceirização, Brasil, 1995 a 2016

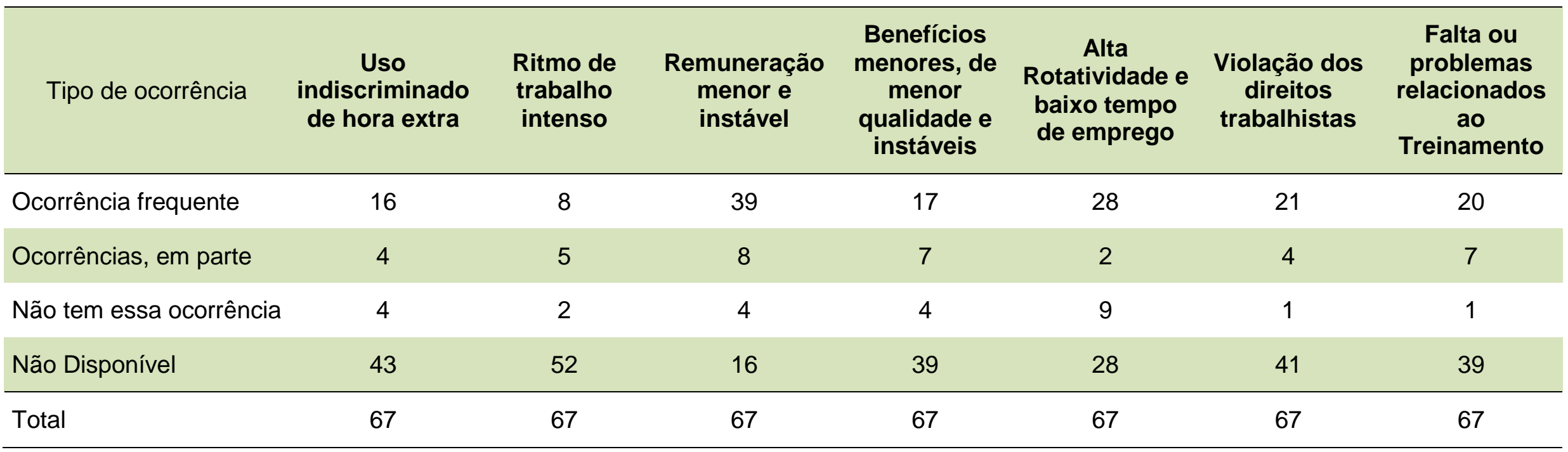

Fonte: RBS - Balanço da produção acadêmica sobre condições e relações de trabalho dos terceirizados, 2019. Elaboração da autora. *Não disponível: nas teses e dissertações estudadas esse tema não foi objeto de investigação na pesquisa de campo. 


\section{- Algumas considerações sobre o código Discriminação}

Quanto ao Eixo Identidade do trabalhador, tema que não foi sistematizado, seria relevante aqui destacar alguns elementos presentes no material estudado. Primeiramente, elaboramos um indicador a partir do código Discriminação, aqui entendida não apenas como as diferenciações objetivas, mas principalmente com as distinções subjetivas.

Nesse código, presente em 15 teses e dissertações, com exceção de um caso, todos os demais $(93,3 \%)$ descreveram evidências de discriminação promovida pelos processos de terceirização, e que fortaleciam a fragmentação entre os trabalhadores diretos e terceiros. Essas ocorrências estão presentes em setores terceirizados que executam suas atividades dentro da empresamãe. A relação cotidiana é permeada por formas diretas e também formas sutis de discriminação, algumas vezes, realizada pela supervisão da empresa terceira, mas na maior parte dos relatos, cometida pelos próprios trabalhadores. Para algumas trabalhadoras, como as do asseio e conservação, a discriminação relatada é sentida com a invisibilidade e o sentimento de inferioridade em relação aos demais trabalhadores (ANDRETA, 2016). Para outros, como as trabalhadoras e trabalhadores terceirizados em atividades financeiras, a discriminação descrita é sentida na segregação dos grupos nas atividades sociais (DIAS, 2011). E ainda, é sentida com a divisão dentro da empresa de locais em que os terceirizados não podem circular (MUNIZ, 2014). Ou, mesmo que não ocorra a separação dos espaços de modo institucional, definido pela empresa tomadora, os trabalhadores não se misturam nos espaços coletivos, como o refeitório (MARCELINO, 2002).

A terceirização promove uma fratura entre os trabalhadores. "Um terceirizado verbalizou: "é um uniforme deprimente"' (MARTINS, 2012, p. 82) e aqui, podemos ampliar esse "uniforme da terceirização" para as demais formas de discriminação, objetivas e subjetivas. A discriminação "avança sendo percebida nas mínimas coisas como regras informais, tratamento cotidiano, convites, inclusão/exclusão" (MARTINS, 2012, P. 82).

Os trabalhadores diretos, mesmo quando tentam evitar a discriminação, acabam reforçando-a, como no registro realizado por Barbosa (2010, p. 121): 
"Apesar de tratarmos os terceirizados com igualdade, nós sabemos que de um modo geral eles são menos qualificados", conclui um trabalhador direto do setor de alumínio. Em outro trecho, o relato de uma trabalhadora de empresa terceirizada no setor de atividades financeiras exemplifica como a discriminação dos trabalhadores diretos, contratados pelo banco, se dá no dia a dia:

Os bancários dizem que não têm mais liberdade de ir a copa almoçar porque sempre está cheio daqueles terceirizados. Se há sujeira nos banheiros, eles sempre atribuem esse fato a gente. Outro dia, sumiu uma comida que um funcionário colocou na geladeira e ele desconfiou de mim. Tudo que acontece de ruim na CEF a culpa é dos terceirizados (Auxiliar de Serviços Gerais, 2009) (DIAS, 2011, p. 198).

Outro exemplo (MARCELINO, 2002), demonstra que os próprios trabalhadores diretos promovem ações que fomentam a discriminação entre os diretos e os terceirizados: após uma mobilização dos funcionários contratados diretamente, a Honda decidiu dar trajes diferentes para seus empregados (brancos), enquanto os da subcontratada receberam uniformes azuis. Os funcionários da empresa terceira passaram a ser chamados de 'smurfs' pelos trabalhadores diretos, em uma referência ao desenho animado com personagens azuis dos anos 80 .

A terceirização tem ainda esse efeito: abala a solidariedade entre os trabalhadores e a substitui por um sentimento de desigualdade promovendo uma hierarquia de poder entre diretos e terceirizados (DRUCK, 1995). Esse efeito da terceirização dificulta as articulações coletivas entre os trabalhadores diretos e indiretos, dificulta a promoção de uma identidade coletiva de trabalhadores. 


\section{- Algumas considerações sobre o código Organização e processo produtivo}

Ainda sobre a Revisão Bibliográfica Sistemática (RBS) gostaríamos de destacar mais um código: Organização e processo produtivo. Um dos elementos relevantes para entender a terceirização como um processo que precariza as condições e relações de trabalho visando à redução de custos, têm como elemento central a organização do processo produtivo.

Como já assinalado, a terceirização precariza as condições e relações de trabalho, e vai além, ela fragmenta os trabalhadores, mas também segmenta, em um primeiro momento, entre diretos e terceiros, mas também através de padrões variados de precarização do trabalho. Essa segmentação é realizada de diversas formas, como pudemos observar ao longo da dissertação. E mais, a segmentação vai além das necessárias, objetivamente, para redução do custo do trabalho. Ela tem elementos que dificultam o estabelecimento de relações sociais entre trabalhadores de diversas empresas, mesmo entre aqueles que convivem no mesmo espaço físico.

Essa segmentação também é aparente nas formas de organização da produção e na organização dos processos de trabalho, que levam em conta a alocação dos serviços e os postos de trabalho, que serão subcontratados. Uma primeira constatação é que há diferenças significativas no processo produtivo, considerando empresas terceirizadas e suas diferentes localizações nos níveis de determinada cadeia produtiva, como o estudo de Barbosa (2013, p. 188) que analisou a cadeia produtiva do setor automotivo em Camaçari, BA: "as inovações produtivas são menos habituais nas camadas inferiores da cadeia produtiva, onde prevalece um processo produtivo mais "restrito" e trabalho de tipo "taylorista"."

Outro ponto é que a terceirização, como afirmamos ao longo da presente pesquisa, se traduz em redução dos custos através da piora generalizada nas condições de trabalho e não pela especialização da produção. Nosso argumento é ainda reforçado pelo fato de que a organização dos processos de trabalho, a direção técnica e os conhecimentos necessários para execução dos serviços, são orientados pela contratante em graus variados, não pela 
terceirizada (DIAS, 1998; REIS, 2003; MARCELINO, 2008), Parte dos fornecedores, os de "primeiro nível" detém alguma autonomia técnica e de desenvolvimento para os demais, a tomadora intervém diretamente empresa terceirizada. Em alguns casos, até as máquinas e equipamentos foram fornecidos pela empresa tomadora para a empresa prestadora do serviço terceirizado.

Decorre dessa direção do processo produtivo e dos serviços, que os trabalhadores terceirizados estão submetidos a uma "dupla supervisão" realizada pela empresa que possui seu vínculo formal, mas também pela empresa tomadora. Isso ocorre com aqueles que estão dentro dos muros da empresa-mãe, mas também com aqueles que estão fora, através de diversos dispositivos, inclusive aqueles que auferem a qualidade dos produtos $\mathrm{e}$ serviços. Até mesmo os trabalhadores de empresas terceirizadas de transporte relataram que são supervisionados pela empresa tomadora com o que eles chamaram de "aparato tecnológico" (OLIVERIA, 2014). Isso ocorre nas empresas privadas, mas também foi bastante destacado nas pesquisas sobre a terceirização no setor público, inclusive, como fato de desconforto para os terceiros, "ter dois patrões" (CUNHA, 2015).

Há um sentimento que permeia de forma invariável os terceirizados na relação hierárquica dentro da instituição: o sentimento de inferioridade. Como são pessoas com vínculo empregatício instável, todos os concursados os tratam como subordinados. Conforme fala de um participante terceirizado: "todos acham que podem mandar em nós porque são concursados e nós terceirizados, mesmo não tendo vínculo de chefia com a gente" (MARTINS, 2012, p.76).

Há também, segundo os relatos, uma escolha estratégica de quais postos de trabalho serão terceirizados: os que causam mais acidentes e adoecimento, já relatado acima, mas também os mais braçais, segmentos que são mais intensivos em mão de obra e também aqueles cuja força de trabalho é mais abundante (BARBOSA, 2010). 


\subsubsection{Contrato individual de trabalho}

Diferente do contrato coletivo de trabalho, que define direitos com cobertura para todos os trabalhadores ou para grupos de trabalhadores (por exemplo, as regras que protegem a gestante), há também um grupo de regras que indica como se dá o contrato individual de trabalho.

A CLT define o contrato individual de trabalho no art. 442 como "(...) 0 acordo tácito ou expresso, correspondente à relação de emprego". Essa legislação também define quem são os sujeitos do contrato (empregador e empregado), determina os termos de formação do contrato (horários de trabalho, salário, atividade a ser exercida, local de trabalho, entre outros), de cessação e de limites ao poder de dispensa, de alteração do contrato, os deveres e obrigação do empregado e do empregador (CLT, Decreto 5.452, 1943). A CLT também define quais são as modalidades de contrato individual de trabalho: indeterminado, determinado; contrato temporário; contrato a tempo parcial; contrato de experiência; contratação especial (exemplo: artistas, radialistas, atletas profissionais de futebol), cooperativas de trabalho (urbanas e rurais) e mais recentemente, contrato intermitente.

Segundo Petrolli (2017), a definição de contrato individual de trabalho na CLT é equivocada, porque o termo correto deveria ser contrato de emprego, isso porque, concretamente, a presente lei determina quais são as características da contratação de um trabalhador para um emprego. De todo modo, o autor define contrato de trabalho como:

O negócio jurídico no qual sobressai o ajuste de vontades, em que uma pessoa física põe sua mão de obra à disposição de outra pessoa física ou jurídica, ou ente sem personalidade, de forma pessoal, não eventual, onerosa e subordinada, sem determinação de prazo ou por prazo determinado (PETROLI, 2017, sem paginação).

O contrato de trabalho é bilateral, ou seja, não existe uma terceira pessoa que possa ser incluída no contrato, apesar de a legislação sobre prestação de serviços ter envolvido uma terceira figura (a empresa terceirizada) nas relações de trabalho/emprego. O contrato de trabalho também é 
estabelecido de forma consensual, entre empregador e empregado: são vedadas formas de trabalho escravo ou análogo a escravo. O contrato também pode ser tácito ${ }^{42}$, porque os direitos garantidos em lei não dependem de haver contrato escrito e assinado: como nos casos em que há fiscalização dos órgãos de trabalho e são encontrados trabalhadores sem carteira assinada, a justiça concede todos os direitos aos trabalhadores, se ficar constatado que se trata de uma relação de trabalho assalariada. $O$ contrato de trabalho deve ter atividade definida a ser executada pelo empregado, mas o risco dessa atividade é de responsabilidade exclusiva do empregador.

O contrato do tipo "PJ" (Pessoa Jurídica) é frequentemente utilizado como um contrato de trabalho individual, ou seja, na prática, ele tem todas as características de uma relação de emprego camuflada por um contrato de prestação de serviços entre duas empresas. A contratação de funcionário na forma de pessoa jurídica (PJ) configura contrato de natureza civil e, portanto, escapa ao requisito de pessoalidade e exclusividade, elementos presentes no contrato individual de trabalho (MOURA, 2010).

Além disso, a reforma trabalhista, que entrou em vigor em novembro de 2017, alterou a contratação dos trabalhadores autônomos, dando garantias àqueles empregadores que a utilizam. A nova Lei permite a exclusividade e 0 uso contínuo dos serviços prestados pelo autônomo e, portanto, não serão considerados pelos órgãos da Justiça do Trabalho como fraude na relação de emprego ${ }^{43}$.

Considerando todas as características do contrato individual de trabalho, podemos afirmar que, no setor privado, o contrato de trabalho é aquele que (1) submete o trabalhador a um salário devido em contrato; e, por outro lado; (2) permite que a direção, ou seja, a forma como esse trabalho deve ser desempenhado, se dê pelo empregador; (3) estabelece que o poder de controle e disciplinar também será estipulado pelo empregador. De modo que não é um contrato provido de igualdade, de simetria - mesmo quando os

\footnotetext{
${ }^{42}$ Isso não ocorre com o servidor público, em que o contrato deve ser escrito e assinado pelas partes.

43"Art. 442-B. A contratação do autônomo, cumpridas por este todas as formalidades legais, com ou sem exclusividade, de forma contínua ou não, afasta a qualidade de empregado prevista no art. $3^{\circ}$ desta Consolidação." Lei 13.467, de 13 de julho de 2017.
} 
trabalhadores participam das decisões sobre algum assunto da vida da empresa - , ainda que seja consensual (BALCÃO, 2000).

É importante destacar que a Reforma Trabalhista (2017) altera e amplia um número significativo de contratos de trabalho individuais, além do contrato autônomo. A principal justificativa apresentada pelo relator do projeto substitutivo da Reforma Trabalhista, Rogério Marinho (PSDB-RN), foi que "O Brasil mudou desde 1943, quando a CLT foi criada. É preciso modernizar as relações de trabalho no Brasil, com novas modalidades de contratação que incluam novas formas de trabalho atuais" (PLC 38/2007).

A Reforma Trabalhista aprovou um "cardápio" de contratos precários que se somam ao contrato temporário e à terceirização aprovados pela Lei 13.429/2017. Esses contratos garantem ao empregador uma variedade de formas de contratação com menores custos do que o contrato por prazo indeterminado. Para os trabalhadores, esses novos tipos de contrato significam inserção no mercado de trabalho com menor proteção, levando ao aumento da heterogeneidade e a precarização no mercado de trabalho. As versões ampliadas de modalidades já existentes ou novas modalidades são: o contrato de teletrabalho; o contrato de trabalho intermitente; o contrato de prestação de serviços nas atividades-fim (terceirização); o contrato de trabalho autônomo; o contrato de trabalho em tempo parcial (PLC 38/2007).

Em relação à rescisão dos contratos individuais de trabalho, a Reforma Trabalhista estabelece mecanismos que fragilizam a proteção ao trabalhador. As novas regras revogam a obrigatoriedade da rescisão de contratos de mais de um ano ser realizada no respectivo sindicato ou perante autoridade do Ministério do Trabalho ou em qualquer outro órgão público. A Reforma Trabalhista inclui no ordenamento jurídico a rescisão do contrato de trabalho de "comum acordo" entre empregado e empregador, reduzindo o pagamento das verbas rescisórias relativas ao aviso prévio e a multa relativa ao FGTS à metade do valor devido ao trabalhador.

As novas regras trabalhistas também facilitam a dispensa imotivada, quando equiparam as dispensas individuais às coletivas, frisando que não há necessidade de autorização prévia de entidade sindical ou celebração de 
convenção ou acordo coletivo, em caso de demissões em massa. Também estabelece a quitação total de débitos trabalhistas em Planos de Demissão Voluntária ou Incentivada (PDV ou PDI), impedindo que o trabalhador recorra à Justiça do Trabalho para reivindicar recálculo das verbas rescisórias. $E$, por fim, cria o "termo de quitação anual de obrigações trabalhistas", pelo qual é facultado a empregados e empregadores firmarem documento anual de quitação de obrigações trabalhistas perante 0 sindicato da categoria, novamente, para que depois do encerramento do contrato individual de trabalho, o empregado não possa recorrer à Justiça do Trabalho para reivindicar algum direito que não foi cumprido durante o vínculo empregatício (DIEESE, 2017). Como debatido no capítulo 1, no Brasil, o descumprimento das Leis Trabalhistas é recorrente, mas os trabalhadores não apelam à Justiça do Trabalho durante o contrato, por receio de retaliação, então costumam aguardar o fim do contrato de trabalho para reivindicar seus direitos.

É importante destacar que, as novas modalidades de contratos individuais de trabalho, as novas regras para modalidades já existentes, além das novas regras para rescisão dos contratos de trabalho, não interferem no universo aqui pesquisado, que é anterior a 2016.

De todo modo, mesmo analisando os contratos precários anteriores à reforma trabalhista, podemos destacar, como argumenta Balcão (2000), que a diversidade de condições de trabalho, fruto da diversidade de contratos de trabalho, facilitam a desarticulação das práticas de representação coletivas, remetendo os trabalhadores para o terreno da relação de trabalho individualizada, reduzindo a visibilidade desses trabalhadores e sua atuação na vida pública. A autora ainda considera que a desmontagem do contrato de trabalho também desmonta as mediações reais e simbólicas, que o coletivo proporcionava, e a terceirização colabora com a promoção dos contratos de trabalho precários e estabelece novo padrão de relações de trabalho.

A terceirização pode comportar tanto os contratos individuais de trabalho em que está presente a "relativa" estabilidade, representada pela assinatura de um contrato por tempo indeterminado, como pode ser implementada com graus variados de vulnerabilidade, dependendo do contrato precário utilizado. Dessa forma, entre os trabalhadores terceirizados, existem aqueles que, apesar de 
não gozarem dos mesmos direitos e benefícios dos trabalhadores diretos, desfrutam de coberturas e garantias sociais asseguradas pela formalidade (os terceirizados fixos ou permanentes). E há aqueles que possuem vínculos mais precários, e que gozam de uma proteção ainda menor (caso dos terceirizados temporários) (MOURA, 2010).

A terceirização colabora com a ampliação dos contratos individuais de trabalho precários, quando fragmenta a contratação dos trabalhadores e invisibiliza essas relações de emprego, seja porque elas ocorrem fora da empresa contratante, seja porque estão em elos da cadeia produtiva com menor valor agregado e ficam pressionadas pelas demandas do elo mais forte, seja porque estão fora da alçada da Justiça do Trabalho e são reguladas pela Direito Civil, por se tratar de uma relação comercial entre empresas (MARCELINO; CAVALCANTE, 2012, p.337). A terceirização ainda facilita a contratação de formas ilegais de trabalho, como a dos trabalhadores sem carteira assinada, o trabalho escravo e o trabalho infantil.

No eixo em questão, Contratos individuais de trabalho, utilizamos como códigos: risco de desemprego, contratos precários, contratos informais/ ilegais, piores formas de trabalho ${ }^{44}$. É importante relatar que consideramos apenas os dados primários sobre as diferentes formas de contratos de trabalho, desde que estivessem relacionados ao processo de terceirização. Desse modo, trabalho a domicílio, por exemplo, só foi considerado quando utilizado como estratégia das empresas para seu processo de terceirização; não classificamos o trabalho a domicílio como terceirização, quando não havia empresa interposta na relação de trabalho. A seguir, no quadro 7 (pagina 129), apontamos as principais evidências encontradas quanto às formas de precarização, a partir da fragmentação e disseminação de contratos individuais de trabalho quando precários ou ilegais.

QUADRO 7 - Códigos e evidências das condições precárias nos Contratos Individuais de Trabalho

\footnotetext{
${ }^{44}$ Conforme OIT, as piores formas de trabalho abrangem o trabalho escravo ou análogos à escravidão, ao recrutamento de criança para prostituição ou pornografia, atividades ilícitas ou qualquer trabalho que prejudique a saúde, segurança ou moral da criança. Mais informações: https://monicajustinomansano.jusbrasil.com.br/artigos/261914013/as-piores-formas-detrabalho-segundo-a-convencao-182-da-oit.
} 


\begin{tabular}{|c|c|}
\hline Códigos & Evidências \\
\hline $\begin{array}{l}\text { Risco de } \\
\text { desemprego }\end{array}$ & $\begin{array}{l}\text { - Ameaça de demissão como forma de controle; } \\
\text { - Utilização da demissão como forma de compatibilidade à } \\
\text { sazonalidade da produção; } \\
\text { - Aceitação de formas precárias devido ao alto desemprego e } \\
\text { desemprego de longa duração; } \\
\text { - Desemprego devido à relocalização/desverticalização em } \\
\text { função da terceirização. }\end{array}$ \\
\hline $\begin{array}{l}\text { Contratos } \\
\text { precários }\end{array}$ & $\begin{array}{l}\text { - Utilização de pessoa jurídica com relação de subordinação, } \\
\text { pessoalidade e habitualidade; } \\
\text { • Utilização de trabalho através de falsas cooperativas de } \\
\text { trabalho; } \\
\text { • Utilização de trabalho cooperado como intermediação de mão } \\
\text { de obra; } \\
\text { - Utilização de trabalho temporário como estratégia permanente } \\
\text { da empresa, e não apenas em momentos eventuais de altas da } \\
\text { produção e serviços não programados; } \\
\text { • Utilização de trabalho temporário como forma de "seleção" de } \\
\text { mão de obra permanente. }\end{array}$ \\
\hline $\begin{array}{l}\text { Contratos } \\
\text { informais/ } \\
\text { ilegais }\end{array}$ & $\begin{array}{l}\text { - Utilização de trabalho a domicílio com estratégia de } \\
\text { terceirização e com empresa interposta; } \\
\text { - Uso de informalidade (sem carteira registrada) de modo } \\
\text { parcial, em períodos eventuais; } \\
\text { - Uso de informalidade (sem carteira registrada) de modo } \\
\text { permanente; } \\
\text { - Terceirização em cascata; quarteirização. }\end{array}$ \\
\hline $\begin{array}{l}\text { Piores formas } \\
\text { de trabalho }\end{array}$ & $\begin{array}{l}\text { - Servidão por dívida; } \\
\text { - Deslocamento de trabalhadoras e trabalhadores a outros } \\
\text { estados sem garantia de alojamento e salário; } \\
\text { - Trabalho infantil. }\end{array}$ \\
\hline
\end{tabular}

Fonte: RBS - Balanço da produção acadêmica sobre condições e relações de trabalho dos terceirizados, 2019. Elaboração da autora.

Elencamos no eixo Contrato individual de trabalho o código "risco de desemprego", porque, nas teses e dissertações analisadas, ele aparece muitas vezes ligado a uma estratégia das empresas para a submissão dos trabalhadores às formas precárias. Destaca-se que, mesmo no período em que havia crescimento do emprego, a partir da segunda metade dos anos 2000, o risco de desemprego continuou a ser um elemento presente nos discursos dos trabalhadores investigados. Nossa hipótese para esse fato, já bastante informada por dados existentes (ver DIEESE, 2017), é que, mesmo com menor 
taxa de desemprego, a taxa de rotatividade ${ }^{45}$ se manteve alta, ou mesmo cresceu, mantendo, de forma permanente, a relação de instabilidade em relação ao vínculo empregatício.

O relato descrito por Dias (1998) em sua dissertação "Educação e relações de trabalho no cenário da globalização: o jogo da terceirização" sobre a fala de um encarregado em uma das indústrias terceirizadas estudadas, retrata bem o uso do desemprego como forma de controle: "(...) a febre do desemprego é a melhor arma para se obter a adesão dos funcionários." e "[quando o trabalhador não cumpre as metas] entra em desespero com crises de choro por medo de ser mandado embora" (p. 85), esclarecendo como esse fator era relevante para garantir que os funcionários cumprissem as metas de produção e se submetessem à pressão e ao assédio da supervisão/direção da empresa. Desse modo, o medo do desemprego e da desorganização da vida pessoal, da privação orçamentária do trabalhador e sua família, garante que a submissão ao trabalho precário seja a única opção. Isso garante ao empregador uma "adesão" ao cumprimento de metas, de realização de horas e de horas extras e mesmo à aceitação da violação de direitos. Abaixo, temos outras ocorrências de como o receio de perder o emprego e a instabilidade permanente, ainda mais para o vínculo de trabalho do terceirizados, permeia o cotidiano de trabalhadores de diferentes setores.

Trabalhadores do setor de asseio e conservação, Santa Maria, RS:

$\mathrm{Na}$ sua fala, T. mostra reconhecer que essas atividades não estão entre as suas designações como funcionária da limpeza. E que o que realiza além de suas funções contratuais não é remunerado. Contudo, parece haver um receio de não realizar as atividades que não são da sua alçada, especialmente, porque sabe que a outra funcionária que ocupava esse cargo antes dela se recusava a fazê-lo - e que foi demitida em virtude de reclamações (ANDRETA, 2016, p. 170).

Trabalhadores no setor de energia elétrica, Paraná:

$\mathrm{Na}$ busca da manutenção do emprego se comportam como "concorrentes". Com isso, o temor da perda do

\footnotetext{
${ }^{45} \mathrm{O}$ código sobre rotatividade será discutido no eixo "condições de trabalho", na seção seguinte.
} 
emprego assume um papel estratégico para 0 neoliberalismo (SANTOS, 2009, p. 148).

Trabalhadores do setor de atividades financeiras no Rio Grande do Norte:

\begin{abstract}
Eu digo que quando não se tem um emprego fixo não se pode programar as coisas nem planejar muito bem a vida. Por isso, evito me comprometer com despesas altas, parceladas em 12 vezes ou mais, e aquisições caras também. Tudo isso porque tenho medo de ficar desempregada. Já planejei comprar um terreno, já programei ter um filho, mas vivo adiando esses projetos porque corro sempre o risco de ficar desempregada e, com isso, não ter dinheiro para pagar o terreno e o bebê desejado passar por privações (auxiliar de processamento de dados, 2009) (DIAS, 2011, p. 190).
\end{abstract}

Por outro lado, para aqueles trabalhadores que estão em situação de desemprego, a contratação via terceirização é uma oportunidade de voltar a ter um rendimento do trabalho, com o desejo de, em um futuro próximo, conseguir um trabalho menos precário. Segundo Mayer (2009), a dificuldade em conseguir um emprego formal, impele os trabalhadores a aceitarem o trabalho cooperado, para realização de atividades de asseio e conservação, em prefeituras do Rio Grande do Sul, para garantir alguma renda para o sustento de suas famílias. Nessa direção, a seguir, apresentamos outra ocorrência nos documentos analisados, referente aos trabalhadores no tele atendimento, Curitiba, PR:

O povo aqui precisa, tá necessitado né. O índice de desemprego tá lá em cima. Eles têm condições de ficar exigindo salários altos? Tem não. Vão morrer de fome se fizerem isso. Se você não quer, três/quatro lá fora vão querer. Eles não têm opções, tem que aceitar e pronto. Eles não têm qualificação profissional nenhuma, porque não têm condição de estudar, um salário de 300 reais, vai pagar faculdade? Como? Por isso, eles aceitam ser explorados. Tem muita gente aí que tá na faculdade, mas vai ver a faculdade, é aquilo, se bobear é a faculdade que paga pra eles tarem lá (MENDES, 2005, p. 65 e 66).

$\mathrm{Na}$ tese "Mudanças organizacionais e diferenciação social: os trabalhadores da indústria do alumínio primário paraense" (BARBOSA, 2010), há um destaque para essa questão. Os trabalhadores terceirizados aceitam o 
emprego na terceira, mas sonham com um dia trabalhar na Albrás/Alunorte, onde teriam acesso aos benefícios existentes na empresa e prestígio em seu círculo social: "Aqui nessa região todo mundo tem vontade de trabalhar na Albrás pelas regalias que ela oferece: escola para filho, medicamento, faculdade, plano de saúde, e outras coisas." (BARBOSA, 2010, p. 57).

Esse desejo aparece com frequência nas teses e dissertações analisadas, em que o terceirizado executa suas atividades laborais em uma grande empresa. É presente também, nos documentos analisados, a situação desigual de estabilidade, seja em comparação com o vínculo de servidor público concursado, ou mesmo em comparação com a instabilidade menor dos trabalhadores diretos do setor privado, em relação aos terceirizados, conforme exemplificada nos trechos a seguir.

Trabalhadores na administração pública, Distrito Federal:

$\mathrm{Na}$ outra ponta, o contrato dos trabalhadores terceirizados não lhes garante estabilidade, ao contrário dos concursados. Repetidas vezes eles escutam verdades ditas de forma tanto cínicas quanto perversas que "precisam cuidar do seu emprego"; que "emprego está difícil... tem uma fila de pessoas esperando para entrar aqui", e que eles tem uma boa oportunidade por estarem ali e que "ganham acima do que o mercado oferece” (MARTINS, 2012, p. 84).

Trabalhadores do setor de Saúde, Campinas, SP:

Ainda que ressalte que essa é uma característica do seu local de trabalho, Fabiano esclarece que ela é possível devido a suas condições objetivas de trabalho, muito diferentes daquelas dos outros profissionais, terceirizados: Então, a questão de eu ser concursado, de eu ter estabilidade, de eu poder questionar, poder propor organização das coisas do jeito que eu acredito e tal! Com certeza, eu não estaria lá, no mesmo lugar até hoje, se eu não tivesse essa chance que eu tenho por ser concursado. Então, quem sabe uma das questões da terceirização do trabalho é você não poder questionar, né? (PIZON, 2016, p. 123).

Trabalhadores do setor de alumínio, Barcarena, PA:

A incerteza do reconhecimento jurídico de algumas garantias sociais, ligadas ao padrão de ocupação característico do padrão fordista de emprego, ainda 
presente na relação entre a Albrás e seus empregados, é um dos elementos constitutivos da diferenciação social entre trabalhadores diretos e terceirizados. Apesar de não haver garantias definitivas sobre a permanência no emprego, os trabalhadores diretos estão menos sujeitos à condição de incerteza que caracteriza essa fronteira entre a ocupação e a não ocupação (BARBOSA, 2010, p. 144 e 145).

Também é frequente que as trabalhadoras e trabalhadores terceirizados avaliem que a responsabilidade é deles por não conseguir um emprego melhor, devido à baixa escolaridade e qualificação profissional insuficiente (BARBOSA 2010). Isso, apesar de os trabalhos demonstrarem que a escolaridade exigida tenha mais a ver com o critério de seleção, diante da abundância de força de trabalho disponível, do que com as tarefas em si mesmas que os trabalhadores das empresas contratantes realizam.

Outra forma de risco de desemprego encontrada é a demissão em massa de trabalhadores em período de baixa na produção. Um dos setores mais emblemáticos dessa estratégia é o de confecção: os trabalhadores são contratados por prazo indeterminado (com ou sem carteira), mas a alta da produção dura alguns meses no ano. No período de baixa produtiva, os trabalhadores são demitidos, em muitos casos, sem pagamento de verbas rescisórias, mas com a promessa de recontratação na próxima temporada, o que constrange os trabalhadores a não reclamarem a violação de seus direitos para serem recontratados. A grande empresa joga o ônus desse processo para as pequenas empresas terceiras.

Trabalhadores da indústria de calçados, Franca, SP:

Como acontece com quase toda banca da cidade, o início do ano é um período de baixa de produção e normalmente os trabalhadores dessas bancas só são chamados ao trabalho por volta de março, abril.

Desse modo, esses trabalhadores experimentam um período de desemprego, "desemprego temporário", previsível todo início do ano (ALMEIDA, 2008, p. 68).

Os documentos analisados também informam como os processos de terceirização interferem nos níveis de emprego: quando se analisa determinada empresa ou setor que promoveu um processo de desverticalização e ocorre 
uma migração do emprego para outro setor (terceirizado) ou para outra região, como no setor de confecção. Um exemplo encontrado nos documentos analisados é a de uma grande empresa do setor de confecção que fechou suas portas na cidade de Cotia, e transferiu sua produção para uma Cooperativa em Sorocaba, SP (AMORIM, 2003). Nesse caso citado, a base sindical teve um enorme refluxo, pois se tratava da maior empresa do setor na cidade. A desverticalização da produção e a relocalização geográfica tem alterado bases sindicais e também gerado conflitos entre diferentes sindicatos, como veremos mais a frente.

Em relação aos contratos precários, é preciso destacar, inicialmente, que apesar de praticamente todas as teses e dissertações tratarem do tema, poucas apresentam dados primários sobre como esse processo se dava em relação ao seu objeto de estudo. Por exemplo, em relação à informalidade, apesar de 42 das 67 teses e dissertações analisadas apresentarem esse debate, resgatando a revisão bibliográfica sobre o tema, em apenas 12 se apresentaram dados originais sobre informalidade, oriundos do trabalho de campo. Não é possível afirmar se essa questão foi investigada e ficou de fora da sistematização, ou se ela não compôs os temas de pesquisa de campo. Isso se repete em outros temas, tais como saúde do trabalhador, acidentes, rotatividade e também nos demais contratos precários aqui analisados.

No primeiro grupo de contratos precários, temos os definidos como legais, por que possuem uma legislação a regulá-los. Tais contratos são amplamente utilizados dentro e fora dos limites estabelecidos em Lei. Consideramos nesse grupo, os contratos de trabalho temporário, os de pessoas jurídicas e o trabalho em cooperativas. $O$ trabalho temporário é utilizado em algumas empresas e setores de modo "permanente", ou seja, não é um trabalho eventual em períodos de alta não programada da produção e de atendimento, como versava a regulamentação no período aqui analisado ${ }^{46}$. É utilizada de modo frequente e permanente, como parte da estratégia de contratação, como demonstra a dissertação a seguir, que estudou o processo de terceirização no setor automotivo, Camaçari, BA:

\footnotetext{
${ }^{46}$ Essas teses e dissertações são anteriores a aprovação da Lei 13.429/2017, que amplia os casos em que é possível utilizar o trabalho temporário.
} 
No mesmo período a demanda por mão-de-obra "permanente flutuante" oscilou entre quatrocentos e quinhentos trabalhadores empregados, ou seja, entre $5 \%$ e $6 \%$ do total de trabalhadores do Complexo, "o que ratifica a afirmação de que a demanda tem viés permanente" (BARBOSA, 2013, p. 142-143).

Trabalhadores do setor de tele atendimento, Curitiba, PR:

No caso específico das empresas de terceirização de call center, essa precarização é representada pelos contratos por prazos determinados. A empresa prestadora de serviço terceirizado é contratada por certo período, geralmente por 12 meses, porém há casos de contratos cujos prazos são menores, de acordo com a campanha ou projeto desenvolvidos pela contratante. Assim, a contratada assume trabalhadores, também, por prazo determinado (MENDES, 2005, p. 65).

Trabalhadores do Correio Nacional:

Os trabalhadores terceirizados são contratados para atuar com vínculo temporário - três meses - como forma da estatal desvencilhar-se de obrigações trabalhistas (TEIXEIRA, 2013, p. 203).

Trabalhadores da indústria química, Camaçari, BA:

Em primeiro lugar, no interior mesmo destas empresas, há uma estratificação e discriminação entre os próprios empregados. Os dados obtidos de forma mais completa e sistematizada referem-se, essencialmente, aos empregados do quadro fixo, pois para os temporários e, principalmente, para os prestadores de serviços, as empresas alegam não ter informações registradas. Isto demonstra que, no caso destes últimos - em geral subcontrados por empreita -, não há registro porque eles não existem formalmente nestas empresas. São aqueles trabalhadores, mais precários ainda, nômades, instáveis e que, com esta pratica de gestão, tornam-se, também, invisíveis. (DRUCK, 1995, p. 199 e 200).

Outra forma de utilização do trabalho temporário é como "seleção" de mão de obra para a contratação por prazo indeterminado. Um exemplo que ilustra esse uso do contrato temporário entre as empresas terceirizadas é no setor automotivo (BARBOSA, 2013). Esse uso do contrato temporário infringia a lei, pois ele deveria ser utilizado no momento de alta da produção não programada, e não como forma de seleção de trabalhadores. Esse período de 
experiência é previsto no contrato por prazo indeterminado e as empresas não precisariam fazer uso do contrato temporário para tal:

O depoimento de um operário, seis meses empregado numa fornecedora de componentes, é ilustrativo por revelar essa diferenciação. Segundo sua declaração, a empresa realiza admissão de trabalhadores sem o devido registro na carteira de trabalho, como forma de seleção do quadro de funcionários. Questionado se houve algum tipo de treinamento na empresa para exercer suas atividades, o operário respondeu: - Teve. Eu fiquei mais ou menos três meses pra passar no teste. Aqui na empresa tem assim: pra poder fichar a carteira mesmo, passa três meses de experiência. Aí, se a pessoa passar, fica. Se não passar... (BARBOSA, 2013, p. 182).

As teses e dissertações analisadas também versam sobre o trabalho em cooperativas como forma de precarização do trabalho e interposição da mão de obra. Há um grupo de 10 teses e dissertações que se dedicaram a estudar essa forma específica de contratação ${ }^{47}$. Em todos os estudos aqui analisados que tratam de cooperativas, a conclusão foi de que seu uso é uma forma ainda mais precária de terceirização do que o realizado por empresas, pois elimina direitos trabalhistas, como o 13ํㅗㄴ salário, o FGTS e a licença maternidade, sem uma compensação salarial e sem que houvesse, de fato, a presença dos princípios de economia solidária do trabalho cooperado.

Em uma cooperativa, por exemplo, a empresa - uma multinacional que produzia jeans - fechou totalmente sua produção e transferiu para uma cooperativa. As trabalhadoras da antiga empresa foram convidadas a compor 0 quadro associativo da cooperativa. Um ex-funcionário da empresa coordenou o processo de fundação e ficou como diretor da cooperativa. Além disso, a empresa multinacional forneceu todas as suas máquinas, definia todo 0 processo de produção, critérios de qualidade e era a única cliente da cooperativa. A relação de trabalho da diretoria da cooperativa com as trabalhadoras era marcada por relações autoritárias e por assédio moral; e a remuneração efetiva era menor do que na multinacional, que agora, se tornara "cliente" da produção terceirizada (AMORIM, 2003).

\footnotetext{
${ }^{47}$ AMORIM, 2003; REIS, 2003; SOUZA, 2003; SANCHES, 2006; OLIVERIA, 2008, CALEFFI, 2008; MAYER, 2009; CAMPOS, 2009; SOBRINHO, 2016; E PINZON, 2016.
} 
A seguir, uma seleção de ocorrências presentes nas teses e dissertações analisadas sobre as condições de trabalho precárias, com direitos reduzidos em relação ao contrato por prazo indeterminado, a insegurança contratual, típica de contratos de serviços terceirizados, e a relação de subordinação e de hierarquia nas relações de trabalho internas à cooperativa, seja em relação à empresa contratante dos serviços das cooperativas, seja em relação à direção da cooperativa, que não promove um processo de trabalho organizado de forma coletiva entre todos os cooperados, ou seja, se constituem como fraude à aplicação do Direito do Trabalho.

Trabalhadoras da saúde em hospital público, Rio de Janeiro, RJ:

Alguns pontos negativos também foram levantados, como, por exemplo, o fato de estarem vinculados a contratos que sofrem licitações frequentemente, deixando uma margem grande de insegurança no trabalho; outro ponto seria a inexistência de um plano de carreira levando a uma fala de compromisso dos profissionais da cooperativa. Foi salientado também que a ausência do13ํㅡ, licença gestação e FGTS estariam diretamente relacionados com a grande rotatividade de profissionais na cooperativa (SOUZA, 2000, p. 66).

Trabalhadores cooperados do setor de asseio e conservação, de serviços agrícolas e de serviços em geral, Pelotas, RS:

Consolidou-se entre os trabalhadores associados a percepção de estarem trabalhando em uma "empreiteira" ou "firma", dentre outras designações recolhidas nos relatos (p. 104).

Quando do término das relações entre cooperativa e associados, grande parcela destes tem recorrido ao Poder Judiciário, afirmando em síntese sua condição de empregados (e não sócios de uma cooperativa), pleiteando a reparação da qual se julgam credores. Considerando que ao término do contrato de prestação de serviços entre o Município de Pelotas e o Consórcio PRTCoopasul, no início do ano de 2008, trabalhavam 429 associados, tendo chegado a contar com aproximadamente 600 trabalhadores associados entre 2003 e 2006, encontrando-se em tramitação mais de trezentas reclamatórias trabalhistas de um total de 595 ajuizadas contra a cooperativa, pode ser obtida a dimensão do que os associados compreenderam da relação até então mantida (MAYER, 2009, p. 115). 
Trabalhadores cooperados da educação privada de ensino superior, São Paulo, SP:

Continuando, perguntamos aos professores sua relação com a IES. Todos os professores tinham relações diretas com as IES, através da coordenação de curso. Com a Cooperativa (COOPES) mantiveram relações burocráticas, ou seja, assinaram contratos de ingresso como cooperado e recebiam seus proventos por produção de aulas dadas.

A relação com o coordenador é exatamente a mesma de uma faculdade que trabalha com sistema de contrato de trabalho. O coordenador realiza reuniões pedagógicas sistemáticas em períodos determinados, nessas reuniões pedagógicas são comunicadas as normas da faculdade, exigido a realização do plano de ensino, então existe uma relação normal de coordenador num nível hierárquico superior ao professor. (Professor F.F., em 13.08.2008) (OLIVEIRA, 2008, p. 52).

Por fim, a contratação de trabalhadores pela modalidade de PJ (Pessoa Jurídica), também é uma estratégia de terceirização do trabalho e disfarça a relação de assalariamento com a contratação do trabalhador como se fosse uma empresa. Na pesquisa, apesar desse tema aparecer em quinze teses e dissertações, os dados e as informações primárias estão presentes em apenas cinco documentos. Dentre os cinco documentos, quatro trataram do uso do PJ com substituição do contrato por prazo determinado, ou seja, é uma relação assalariada, com subordinação, pessoalidade e habitualidade fraudada com 0 uso do contrato de Pessoa Jurídica.

Entre os contratos precários considerados ilegais, temos a forte presença nas empresas terceirizadas de trabalhadores informais, sem carteira de trabalho assinada, como revelam os documentos que apresentaram essa temática, conforme veremos nos exemplos a seguir. Esse dispositivo é raramente encontrado na empresa contratante, mas de uso corrente, em parte ou no todo, entre as empresas terceiras.

Indústria petroquímica, Mossoró, RN:

Não há, portanto, um controle eficaz da Petrobras em relação aos recolhimentos de FGTS e de verbas previdenciárias pelas empresas contratadas. A precariedade da fiscalização concorre, ainda, para a contratação de trabalhadores sem carteira assinada. Considerável parcela $(26,3 \%)$ dos casos analisados diz 
respeito à falta ou à irregularidade no registro dos empregados (SOBRINHO, 2006, p. 47).

Trabalhadoras na confecção Criciúma, SC:

O Sindicato dos Trabalhadores estima que a informalidade chega a $40 \%$, mas os faccionistas entrevistados afirmam que chega a $90 \%$, como os faccionistas estão mais próximos dos concorrentes, por assim dizer, acreditamos que suas estimativas estejam mais próximas da realidade (CALEFFI, 2008, p. 105).

Trabalhadores na indústria de confecções, região carbonífera, SC:

O índice de costureiras não fichadas é alto, principalmente nas micro e pequenas confecções e sobretudo nas facções. Tomemos como exemplo três facções em lçara: com 16, 12 e 10 empregados, o número de empregados fichados era respectivamente seis, um e um. Isso demonstra que os dados sobre mão de obra são dispersos, dificultando as atividades sindicais (GOULARTI FILHO, 1995, p. 105).

Outra forma de contratação ilegal é a quarteirização, ou seja, a terceirização em cascata. Como dito anteriormente no capítulo 1, a quarteirização se dá quando a empresa terceira repassa parte ou toda a execução dos serviços para o qual foi contratada para outra empresa, estabelecendo uma longa cadeia de subcontratações, proporcionando novas formas de trabalho precário e facilitando ainda mais a liberação da empresa contratante de prejuízos com reclamações trabalhistas (MARCELINO; CAVALCANTE, 2012).

Nesse caso, a empresa contratante, fica cada vez mais distante do local efetivo de produção, afastando-se ainda mais dos conflitos e de possíveis processos trabalhistas, dificultando a caracterização da responsabilidade subsidiária. Essa forma de terceirização foi destacada na pesquisa sobre a indústria naval, em Rio Grande, no Rio Grande do Sul (SILVA, 2016); na pesquisa sobre as trabalhadoras do setor de confecção, na região do Vale do Rio Itapocu, em Santa Catarina (VENTURIN, 2016); na Petrobras, em São Francisco do Conde, Bahia (BRITO, 2014); na indústria química, em Campinas, São Paulo (MARCELINO, 2008); na indústria calçadista (aglomerados produtivos), Franca, São Paulo (CRICO, 2006). 
Ainda nesse grupo, incluímos o trabalho a domicilio, desde que intermediado por uma empresa. Segundo Almeida (2008, p. 65), o trabalho a domicílio existente na indústria calçadista sofreu alterações ao longo das últimas décadas, e em muitos casos, agora, faz parte da cadeia de produção promovida pela terceirização:

(...) o que existia em Franca até a metade da década de 80 , era uma externalização por contingência, quando a demanda escapava à capacidade produtiva das indústrias instaladas, o que muitas vezes ocorria dada a abrupta entrada do sapato francano no mercado mundial a partir da década de 70 (ALMEIDA, 2008, p. 65).

A partir da década de 1990, o trabalho a domicilio se tornou estrutural na produção de setores como confecção e calçados. Com esse processo, há também o surgimento de microempresas, formais e informais, que intermediam o trabalho a domicílio com a grande empresa. Segundo Almeida (2008), essa nova configuração promove também uma alteração nas relações de trabalho e nas relações familiares - há uma disseminação de valores como empreendedorismo e meritocracia; os homens ingressam no setor de modo mais efetivo, assumindo o controle das microempresas, muitas vezes, reservando às suas esposas a condição de empregadas. E relata em sua pesquisa:

As médias e pequenas indústrias mantêm relação direta com um banqueiro, o "gato", que assume a posição de intermediário, pois pega o trabalho de costura manual nas indústrias e repassa para costureiras domiciliares que, na grande maioria dos casos, trabalham na informalidade e recebem por produção. Essa é a forma de trabalho mais precária que encontramos entre os vários tipos de terceirização do setor na cidade, a que possui menor rendimento, nenhum direito trabalhista e o estigma de ser um trabalho complementar à renda da família, de menor valor monetário e simbólico. (ALMEIDA, 2008, p. 127).

Por fim, conforme definição da OIT sobre as piores formas de trabalho, a sistematização das teses e dissertações sobre condições e relações de trabalho dos terceirizados aqui realizada encontrou ocorrências de trabalho escravo e trabalho infantil. As ocorrências de trabalho escravo se deveram à dívida por servidão (ALMEIDA, 2008) e deslocamento de trabalhadores com promessa de alojamento e trabalho. No caso de trabalho infantil, todas as 
ocorrências foram no setor de calçados. Nesse caso, a compreensão generalizada dos pais e a defesa dos contratantes são de que eles "pegam as crianças para ensinar uma profissão" e de que é "melhor [isso] do que ficar na rua". É uma defesa do trabalho infantil como prática formativa, tanto do ponto de vista moral como profissional.

Em relação ao trabalho infantil, destacamos abaixo alguns trechos que exemplificam o uso das crianças na produção terceirizada.

Trabalhadores na indústria calçadista, Franca, SP:

"De criança, às vezes, eu pego com 12 anos para ensinar, às vezes, eles fica, depois que eles começam a aprender alguma coisa, eles ganha. Além de eu não ganhar para ensinar, eu ensino e depois eu vou pagando os pouquinhos que eles fazem para incentivar eles. E sai tudo empregado, não tem um que não sai empregado" (ALMEIDA, 2008, p. 83).

Trabalhadores da indústria calçadista (aglomerados produtivos), Franca, SP:

A mão-de-obra mais utilizada nas bancas de pesponto é a das mulheres, dos jovens e crianças, todos trabalhando em condições precárias, contribuindo para 0 barateamento da produção. Às crianças e aos adolescentes cabem as atividades de colar, dobrar e aparar, cortar linha, lixar peças de couro e outros (CRICO, 2006, p. 53).

Trabalhadores na indústria de calçados, RS:

Chamou-nos atenção o significativo percentual de crianças (17\%) que afirmaram não receber nenhum tipo de rendimento pelo seu trabalho. Nove crianças responderam que trabalham somente pela comida. (SOUZA, 2005, p. 371).

A maior parte das crianças trabalha sem a utilização de equipamentos de proteção, pois como o trabalho infantil não é permitido, não existem equipamentos adequados para o tamanho delas (SOUZA, 2005, p. 335).

Trabalhadores no setor de energia elétrica, Minas Gerais:

(...) trabalhadores encontrados em situação análoga à escravidão. No ano de 2014 a Cemig foi responsabilizada pelo Ministério Público do Trabalho (MPT) e Ministério do Trabalho e Emprego (MTE) pelo flagrante de 179 
trabalhadores em condições análogas à de escravidão. Os trabalhadores eram submetidos a jornadas de mais de 11 horas por dia, dentre outros abusos (FIGUEIREDO, 2015, p. 82).

Novamente, de modo a sistematizar as informações sobre esse eixo de forma gráfica, apresentamos as informações do eixo Contratos individuais de trabalho no Gráfico 3 (página 143). A análise contou com 45 teses e dissertações que apresentaram dados e informações primárias, referentes a um ou mais códigos aqui investigados. Em termos percentuais, nos 67 documentos analisados nesse eixo, 43,8\% apresentaram condições precárias quanto ao contrato de trabalho; outros $29,2 \%$ apresentaram problemas em partes, ou seja, apesar do tipo de contrato ter algum efeito negativo, não acomete todos os trabalhadores terceirizados. Segundo a análise, em apenas 2,2\% dos casos investigados não há precarização dos terceirizados através dos contratos de trabalho. Do total de 67 de teses e dissertações analisadas, 24,7\% (22 teses e dissertações) não possuíam informações sobre os códigos relacionados a esse tema na pesquisa de campo.

Na tabela 9 (página 144), analisamos de modo mais desagregado os dados do parágrafo acima. Considerando os códigos desse eixo, houve ocorrência das piores formas de trabalho (aqui, trabalho escravo e infantil) em 7 documentos nos quais foram relatadas a existência de trabalho infantil e análogo ao escravo, ou foram relatados a intervenção dos órgãos públicos de fiscalização antes que ocorresse a submissão ao trabalho escravo propriamente dito, por isso, nesse caso, consideramos "em parte".

Em segundo lugar, temos a ocorrência de risco de desemprego, presente 22 documentos analisados, de forma permanente ou de forma parcial. $\mathrm{Na}$ sequência, dos 19 documentos que pesquisaram as ocorrências sobre a contratação através da informalidade/ilegalidade, 11 destacaram dados da existência dessas formas precárias de contratação para a totalidade ou para a maior parte dos trabalhadores; em outros 7 documentos foi relatada a presença desses contratos de forma parcial. 


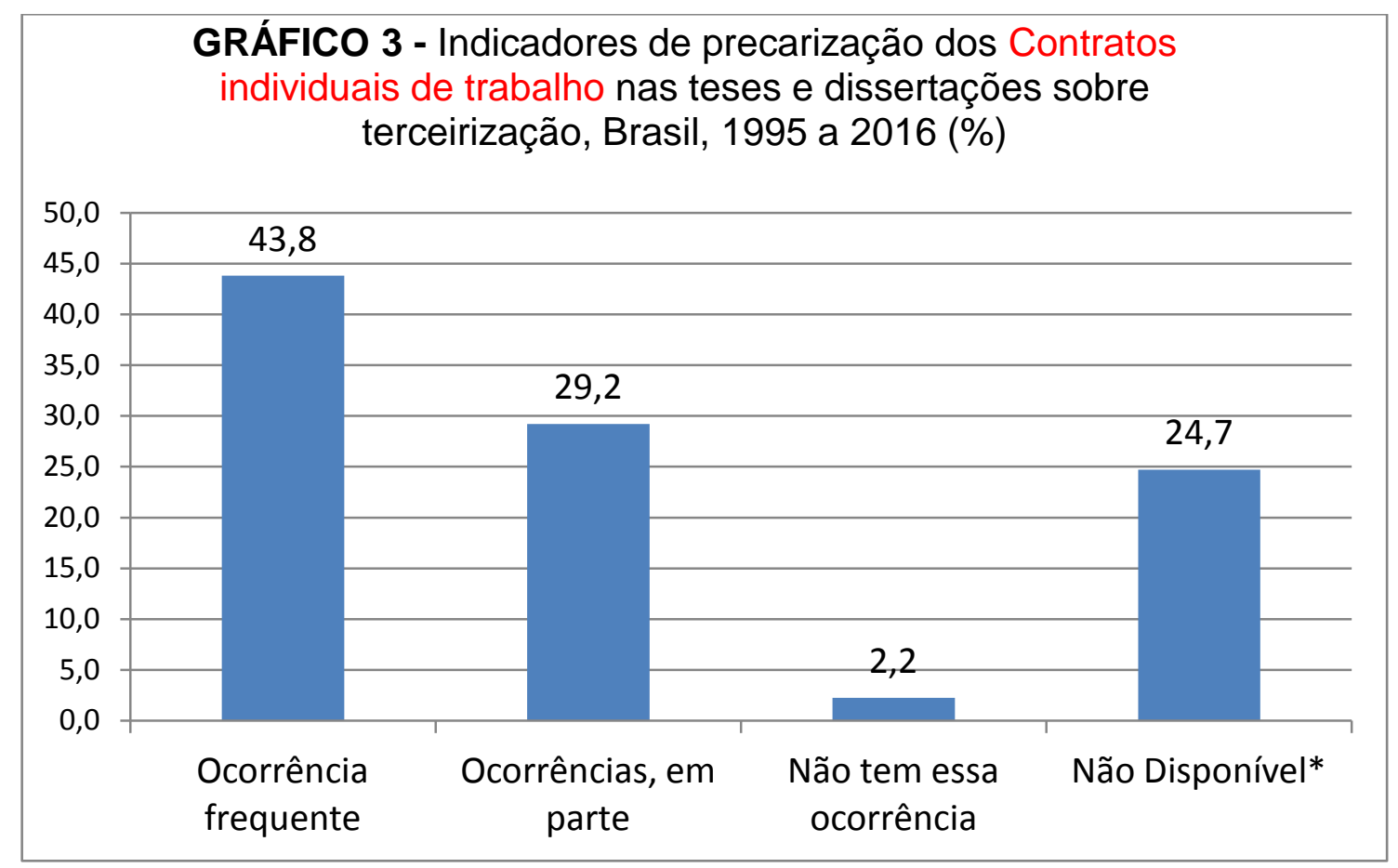

Fonte: RBS - Balanço da produção acadêmica sobre condições e relações de trabalho dos terceirizados, 2019. Elaboração da autora. *Não disponível: nas teses e dissertações estudadas esse tema não foi objeto de investigação na pesquisa de campo.

TABELA 9 - Frequência dos indicadores de precarização do trabalho do eixo Contratos Individuais de Trabalho, presentes nas teses e dissertações sobre terceirização, Brasil, 1995 a 2016

\begin{tabular}{lcccc}
\hline Tipo de ocorrência & $\begin{array}{c}\text { Risco de } \\
\text { desemprego }\end{array}$ & $\begin{array}{c}\text { Contratos } \\
\text { ind. } \\
\text { precários }\end{array}$ & $\begin{array}{c}\text { Contratos } \\
\text { informais/ } \\
\text { ilegais }\end{array}$ & $\begin{array}{c}\text { Piores } \\
\text { formas de } \\
\text { trabalho }\end{array}$ \\
\hline Ocorrência frequente & 14 & 8 & 11 & 6 \\
\hline Ocorrência, em parte & 8 & 10 & 7 & 1 \\
Não tem a ocorrência & 0 & 1 & 1 & 0 \\
Não Disponível & 45 & 48 & 48 & 60 \\
\hline Total & 67 & 67 & 67 & 67 \\
\hline
\end{tabular}

Fonte: RBS - Balanço da produção acadêmica sobre condições e relações de trabalho dos terceirizados, 2019. Elaboração da autora. *Não disponível: nas teses e dissertações estudadas esse tema não foi objeto de investigação na pesquisa de campo.

Os contratos individuais de trabalho - sejam eles legais ou ilegais e aplicados como forma estrutural ou parcial —, são facilitados e potencializados pela terceirização. Mesmo as piores formas de trabalho, como o escravo e 
infantil, são facilitados por uma longa cadeia de terceirização e trabalho precário sem fiscalização, seja do poder público, seja das empresas contratantes. Constatamos, assim como Moura (2010), que as estratégias de contratação variam entre os produtos e serviços: dentro da empresa contratante, contratos formais e precários; fora da empresa contratante, formas ilegais de contratação, como a presença de trabalhadores sem carteira; na terceirização, em cascata. E ainda, que a extensão do uso dos diferentes tipos de contratação que precarizam as condições dos trabalhadores comprova que são facilitados pela terceirização, como afirmam Marcelino e Calvancate (2012), Balcão (2000) e Souto Maior (2017).

Longe de ser uma ferramenta de dedicação da empresa principal ao seu core business é sim uma forma de redução e de externalização dos custos com a força de trabalho, seja do ponto de vista econômico ou do político (MARCELINO E CAVALCANTE, 2012). 


\subsubsection{Saúde do trabalhador}

O tema da saúde do trabalhador é, sem dúvida, de grande relevância nas relações de trabalho, pois diz respeito à garantia da própria existência física do trabalhador. Esse tema é ainda mais importante quando analisamos a terceirização como um dos recursos que as empresas contratantes utilizam para eliminar sua responsabilidade trabalhista, social e financeira com as fases do processo mais insalubres e perigosas de suas operações.

Os índices de acidentes e doenças de trabalho no Brasil sempre foram altos, mas é possível estabelecer uma correlação com o aumento desses índices e a ampliação das formas de precarização do trabalho no último período, especialmente a partir da década de 90. O esgotamento físico e psíquico, o aumento na incidência de estresse e acidentes de trabalho, de doenças do trabalho e relacionadas ao trabalho, como depressão, transtornos psicossomáticos, transtornos de ansiedade, lesões por esforços repetitivos, distúrbios osteomusculares, repercutem de forma negativa na vida laboral e também na vida familiar e social do trabalhador (AQUINO, SABOIA, MELO, CARVALHO, XIMENES, 2015).

A terceirização aprofunda os problemas relacionados à saúde do trabalhador, primeiramente porque as empresas contratantes "terceirizam" os riscos de sua atividade laboral. Em segundo lugar, porque as relações de trabalho próprias da terceirização amplificam a instabilidade no emprego, o sentimento de "trabalhador de segunda classe" e a pressão pela realização de metas, dilatando as fontes que acometem a saúde do trabalhador (AQUINO, SABOIA, MELO, CARVALHO, XIMENES, 2015; DIEESE, 2011).

Segundo Gomez, Vasconcellos e Machado (2018), os estudos atuais sobre a saúde do trabalhador no Brasil (pelo menos a partir da década de 70) têm como referência os condicionantes saúde-doença no processo de trabalho, refutando as concepções que estabelecem leituras simplificadas entre causa e efeito, buscando uma análise que considere uma perspectiva multicausal, incluindo a dimensão social e histórica do trabalho e o binômio saúde/doença:

A saúde do trabalhador configura-se como um campo de práticas e de conhecimentos estratégicos interdisciplinares - técnicos, sociais, políticos, humanos -, 
multiprofissionais e interinstitucionais, voltados para analisar e intervir nas relações de trabalho que provocam doenças e agravos. Seus marcos referenciais são os da Saúde Coletiva, ou seja, a promoção, a prevenção e a vigilância (GOMEZ, VASCONCELLOS E MAÇHADO, 2018, p.1964).

O resultado dessas concepções, somado aos movimentos por saúde pública na década de 80 , foram responsáveis por incluir a saúde do trabalhador na Constituição Federal, concebendo como área de competência da saúde pública executar as ações de vigilância sanitária e epidemiológica (GOMEZ, VASCONCELLOS E MACHADO, 2018; CF 88, Inciso II, Art. 200). Esse campo tem se consolidado e elaborado políticas de prevenção e atendimento à saúde do trabalhador, mas também tem sido alvo de ataques aos serviços públicos, além de enfrentar os novos problemas de saúde, advindos dos processos de reestruturação produtiva.

Em nossa análise, investigamos o eixo de Saúde do Trabalhador através dos códigos: ambiente de trabalho, doenças do trabalho, acidentes de trabalho, equipamentos de proteção individual e coletiva e assédio moral e sexual. As principais evidências sobre o cenário negativo para os trabalhadores terceirizados no presente eixo estão descritos no quadro abaixo. Como se pode observar, a lista de evidências que atingem negativamente a saúde do trabalhador é bastante extensa.

QUADRO 8 - Códigos e evidências das condições precárias para a Saúde do trabalhador terceirizado

\begin{tabular}{|l|l|}
\hline \multicolumn{1}{|c|}{ Códigos } & \multicolumn{1}{c|}{ Evidências } \\
\hline & - Alojamentos em péssimo estado; \\
& - Ambiente muito quente; \\
& - Banheiros insuficientes; ou inexistência de banheiros para cada \\
Ambiente de & - Barulho intenso; \\
trabalho & - Equipamentos de trabalho com problemas; falta de \\
& - Equipamentos; \\
& - Falta de higiene nos espaços coletivos; \\
& - Fiscalização da segurança no local de trabalho inadequada; \\
& - Iluminação inadequada; \\
& - Mobiliário em mal estado; \\
& - Problemas de ventilação; fortes odores;
\end{tabular}




\begin{tabular}{|c|c|}
\hline Códigos & Evidências \\
\hline & $\begin{array}{l}\text { - Problemas prediais (fiação, hidráulica, telhado); } \\
\text { - Sem local para descanso ou em local inapropriado; } \\
\text { - Sem refeitório ou em locais inapropriados para refeições; } \\
\text { - Trabalho em local aberto sem proteção adequada; }\end{array}$ \\
\hline $\begin{array}{l}\text { Doenças de } \\
\text { trabalho }\end{array}$ & $\begin{array}{l}\text { - Cansaço físico extremo e dores musculares; } \\
\text { - Demissão após o fim da estabilidade do auxílio doença; } \\
\text { - Desenvolvimento de alergias; } \\
\text { - Doenças de pele; } \\
\text { - Doenças renais; } \\
\text { - Dores de cabeça; } \\
\text { - Falta de política para reinserção de reabilitados na empresa } \\
\text { - } \text { contratante e na terceirizada; } \\
\text { - Falta de postos de trabalho adequados para reabilitados; } \\
\text { - Falta de treinamento sobre ergonomia; } \\
\text { - Falta de treinamento sobre políticas de saúde e segurança; } \\
\text { - Grande índice de trabalhadores afastados por auxílio doença; } \\
\text { - Intoxicação por produtos de uso corrente no trabalho; } \\
\text { - Lesões por esforços repetitivos; } \\
\text { - Não emissão de CAT para doenças; } \\
\text { - Problemas de coluna e pescoço; } \\
\text { - Problemas de varizes; } \\
\text { - Problemas gástricos; } \\
\text { - Problemas ouvidos; } \\
\text { - Problemas relacionados à voz; } \\
\text { - Restrições à utilização do banheiro; } \\
\text { - Transtornos relacionados à saúde mental (depressão, stress); }\end{array}$ \\
\hline $\begin{array}{l}\text { Equipamentos } \\
\text { de segurança } \\
\text { individual e } \\
\text { coletivo }\end{array}$ & $\begin{array}{l}\text { - Demora na troca de equipamentos; } \\
\text { - Equipamentos de baixa qualidade; } \\
\text { - Falta de equipamentos; } \\
\text { - Falta de treinamento para o uso correto dos equipamentos; }\end{array}$ \\
\hline $\begin{array}{l}\text { Acidentes de } \\
\text { trabalho }\end{array}$ & $\begin{array}{l}\text { - Acidentes fatais; } \\
\text { - Cortes e perfurações; } \\
\text { - Falta de treinamento sobre políticas de segurança; } \\
\text { - Mutilação de partes do corpo; } \\
\text { - Não emissão de CAT para acidentes de trabalho; } \\
\text { - Perda de membros; } \\
\text { - Queimaduras; } \\
\text { - Risco de acidentes ampliados; }\end{array}$ \\
\hline $\begin{array}{l}\text { Assédio moral } \\
\text { ou sexual }\end{array}$ & $\begin{array}{l}\text { - Assédio sexual verbal ou físico; } \\
\text { - Constrangimentos para que o trabalhador não reclame das } \\
\text { condições de saúde e segurança, de doenças ou acidentes de } \\
\text { trabalho; } \\
\text { - Pressão para atingir metas e resultados; } \\
\text { - Submissão a condições precárias de saúde por medo de } \\
\text { perseguição, represália e demissão; } \\
\text { - Xingamentos em relação à execução do trabalho ou ao próprio } \\
\text { trabalhador. }\end{array}$ \\
\hline
\end{tabular}


Fonte: RBS - Balanço da produção acadêmica sobre condições e relações de trabalho dos terceirizados, 2019. Elaboração da autora.

Em Ambiente de trabalho, encontramos relatos de locais de trabalho ou alojamentos em condições inapropriadas de higiene, temperatura, barulho, mobiliário, riscos de incêndios, problemas de manutenção predial, falta de banheiros, locais de descanso e de refeitório. Entre tantos relatos, talvez a microempresa de confecção sem piso, diretamente na terra, e em que a produção precisava parar quando chovia devido a problemas no telhado por falta de manutenção (CRICO, 2006), e o incêndio de um alojamento onde residiam 40 trabalhadores, de uma empresa terceira do setor naval (SILVA, 2016), tenham sido as situações mais limites nesse quesito. Essas precárias condições nos ambientes de trabalho interferiam diretamente na segurança e proteção à saúde das trabalhadoras e trabalhadores terceirizados, expondo-os a condições insalubres de trabalho. Abaixo, alguns relatos selecionados que descrevem os ambientes de trabalho.

Trabalhadoras no asseio e conservação em uma universidade pública:

À exceção de uma das entrevistadas, todas as participantes da pesquisa realizam suas refeições em locais diferentes dos trabalhadores efetivos. No caso das trabalhadoras que prestam serviços na Universidade Federal de Santa Maria (UFSM/RS), contratadas pela Alfa, o seu local de refeições e de descanso costuma estar localizado nas peças situadas embaixo das escadas, local onde alguns materiais ficam armazenados. Por serem peças embaixo das escadas, são pequenas, mal iluminadas e cabem poucas trabalhadoras por vez.

Ao contrário dos funcionários efetivos da Universidade Federal de Santa Maria, as terceirizadas não possuem direito de acesso ao restaurante universitário (RU) (ANDRETA, 2016; p. 179).

Trabalhadoras no setor de confecção, em Criciúma, SC:

Ambiente: - as cadeiras são de palha, instalações elétricas precárias, fiação solta, má iluminação, ruído e poeira, garrafas de água sobre as máquinas, o que pode provocar acidente. Falta ventilação, no verão o calor é excessivo, principalmente porque os motores das máquinas emitem calor, aquecendo 0 ambiente. $O$ ventilador atrapalha porque embaraça as linhas das máquinas, com exceção da máquina reta ponto-fixo uma 
agulha, pois é só uma linha na parte superior, as demais máquinas de costura, como overloque e galoneira as linhas embaraçam, então a velocidade do ventilador é reduzida, aumentando o calor (CALEFFI, 2008; p. 70).

Trabalhadores de Tecnologia da Informação (TI) na administrarão pública federal, Distrito Federal:

Enquanto os servidores concursados trabalham em salas com belas vistas em andares elevados, a maioria dos terceirizados fica lotada em um subsolo em salas apertadas, empoeiradas e úmidas, não conseguem captar sinais de telefones móveis. Neste subsolo alguns materiais de limpeza também são armazenados por algumas horas antes de serem recolhidos. Um dos funcionários terceirizados expressou o desprezo da direção em relação a essas condições: "quantas vezes o nosso diretor foi lá ver a gente? Duas ou três vezes. Quando chega lá fala: isso aqui é um poleiro de galinha" (MARTINS, 2012, p. 77).

Trabalhadores em atividades financeiras de São Paulo, SP:

As condições de trabalho, segundo relatos dos trabalhadores, são precárias. As empresas terceirizadas ocupam um espaço físico pequeno para o número de pessoas que ali trabalham, há poucos banheiros, refeitório pequeno e móveis inadequados ou mesmo quebrados. Conforme relata um terceirizado, "quem chega primeiro, pega as melhores cadeiras, quem chega depois, cai do cavalo". Essas condições geram constrangimento e insatisfação. Ao descrever as condições de trabalho, uma trabalhadora diz: $O$ auditório que nós trabalhávamos era varrido uma vez por semana, era um galpão, então era uma poeira enorme (...) um calor enorme, era telha Brasilit (SANCHES, 2006, p. 96).

Destaca-se que, quando o terceirizado realizava suas atividades dentro das dependências da empresa contratante, muitos desses problemas permaneciam, pela separação de espaços para trabalhadores diretos e terceirizados. Como no caso dos trabalhadores de TI na administração pública federal, ou dos trabalhadores do asseio e conservação em universidades públicas, citados acima. Nesse caso, é frequente a reclamação dos trabalhadores terceirizados sobre o fato de o refeitório, vestiário e local de descanso (quando existem) se encontrarem em um subsolo, em local sem 
ventilação, sem manutenção ou limpeza adequados, ou, ainda, distante de seu posto de trabalho.

Essa diferenciação dos espaços de higiene, refeitório e descanso também é apontada pelos trabalhadores como uma forma de discriminação dos terceirizados em relação aos trabalhadores diretos, e que acentua as dificuldades de relação entre os diferentes grupos de trabalhadores nos espaços da empresa, interferindo negativamente na construção de uma identidade de classe, independente do vínculo empregatício (DIAS, 2010). Ou seja, o espaço físico das empresas também é utilizado como instrumento de segregação e fragmentação dos trabalhadores, gerando, inclusive, disputas quando o terceirizado "invade" um local de descanso, refeitório ou banheiro destinado aos trabalhadores diretos.

Nesse grupo de informações (ambiente de trabalho), também foram encontrados, nos documentos analisados, o relato de falta de equipamentos de trabalho ou a existência de equipamentos inapropriados para a execução das tarefas. Ainda, além das condições inapropriadas para a saúde e segurança dos trabalhadores, encontramos relatos de que isso interfere negativamente no desempenho das atividades laborais e no não cumprimento de metas de atendimento ou produção, como no estudo de caso sobre professores contratados através de cooperativas de trabalho, em que equipamentos de trabalho como computador e acesso a internet eram oferecidos de forma precária e os trabalhadores precisavam utilizar seus próprios equipamentos (OLIVEIRA, 2008). Outra ocorrência é a destacada por Santos (2006) relativa aos trabalhadores de tele atendimento, em que as falhas nos sistemas, os computadores lentos, a falta de cadeiras adequadas e de equipamentos para descanso dos pés, interferem negativamente no cumprimento das metas estabelecidas.

Em relação às doenças do trabalho e relacionadas ao trabalho a lista é bastante ampla. Há uma diversidade grande de doenças que atingem partes do corpo e que estão relacionadas ao tipo de atividade profissional desempenhada: problemas de coluna entre as pessoas que executam suas tarefas na confecção, calçados e indústria metalúrgica; LER/DORT no tele atendimento e atividades financeiras; problemas vocais e auditivos e infecções 
urinárias nos trabalhadores de telemarketing; contaminação e intoxicação com produtos tóxicos no asseio e conservação, na indústria de calçados e nas indústrias química. É recorrente a presença de relatos nos documentos que expressam dados sobre o maior adoecimento para os trabalhadores terceirizados do que para os trabalhadores diretos. Abaixo, alguns trechos que exemplificam as ocorrências encontradas nos documentos analisados que tratam do adoecimento das trabalhadoras e trabalhadores terceirizados.

Trabalhadoras no setor de confecção, Criciúma, SC:

Doenças de trabalho: • Costureiras: a principal doença ocupacional está relacionada a problemas de coluna. Observamos que não há nenhuma orientação quanto à postura adequada para sentar na cadeira; $\bullet$ Passadeiras: observamos em todas as facções o uso do ferro de passar com $3,5 \mathrm{~kg}$ em média, o que ocasiona LER. As chefias, indagadas sobre a utilização desse ferro, alegaram que quanto mais pesado, o trabalho fica mais bem feito; - Revisoras: trabalham em pé, praticamente nove hora por dia, a doença ocupacional mais comum são varizes nessas trabalhadoras (CALEFFI, 2008, p. 70-71).

Trabalhadores do setor de tele atendimento em Fortaleza, CE:

Entre os problemas de saúde mais frequentes foram citados: dores nos ombros, braços ou mãos $(18,24 \%)$; tendinite $(14,86 \%)$; problemas com a audição, como perda auditiva, dores e/ ou inflamação nos ouvidos $(10,81 \%)$; dores no pescoço ou na coluna $(10,81 \%)$; estresse (10,14\%); dores de cabeça ou enxaqueca $(8,11 \%)$; problemas com a voz, como afonia, dores e inflamação na garganta $(7,43 \%)$; alterações no sistema nervoso, tais como irritação, nervosismo, impaciência, ansiedade e raiva $(3,38 \%)$; problemas de vista, como dor nos olhos (3,36\%); depressão $(2,70 \%)$; gastrite, inclusive nervosa $(2,03 \%)$; bursite $(1,35 \%)$; cansaço físico e mental (1,35\%); problemas psicológicos (1,35\%); entre outros, tais como síndrome do pânico $(0,68 \%)$, insônia $(0,68 \%)$ e dores musculares em geral $(0,68 \%)$ (CAVAIGNAC, 2010, p. 206).

Adoecimento dos trabalhadores do setor automotivo, Camaçari, Bahia:

.... O ritmo do trabalho na linha de montagem, a falta de pausas durante a jornada e, principalmente, "a pressão por resultados e a execução de movimentos leves e repetitivos" (p. 145). 
A evolução dos casos de LER/DORT no município após a instalação da corporação americana permite observar que em apenas três anos, o número de casos de LER/DORT cresceu assustadores 280\% (BARBOSA, 2013; p. 146).

Trabalhadores do asseio e conservação na educação pública superior:

Em 2011, caso se compare a frequência absoluta (CAT comunicação por acidente de trabalho) das empresas terceirizadas com a frequência absoluta - CAT dos empregados da FUB, tem-se uma ideia do tamanho da discrepância. Enquanto no primeiro exemplo, somando a frequência absoluta de acidentalidade de todas as empresas terceirizadas, obtém-se 129 casos de acidentes, no quadro de trabalhadores efetivos da universidade esse número é de apenas três ocorrências.

No ano seguinte, a frequência absoluta foi de 97 casos de acidentalidade com os trabalhadores terceirizados, contra apenas uma ocorrência de acidente com trabalhadores do quadro efetivo (COSTA, 2016; p. 126).

Além desses grupos de doenças há também destaque para doenças psíquicas, como depressão, estresse e crises de ansiedade, como o relatado no setor de tele atendimento em Fortaleza, CE (CAVAIGNAC, 2010), e das trabalhadoras da confecção, em Cianorte, PR (LIMA, 2009). Destaca-se a dificuldade dos trabalhadores e trabalhadoras em estabelecer o nexo causal (a relação entre o adoecimento do trabalhador e o exercício da atividade laboral) e conseguir os benefícios previdenciários, no caso dos trabalhadores terceirizados com carteira assinada.

Trabalhadoras no setor de confecção, Criciúma, SC:

Ninguém fala sobre assédio moral, e isso acontece bastante, isso prejudica porque as pessoas chegam aqui com depressão, a gente não pode nem encaminhar uma CAT que o INSS não aceita, porque depressão não é uma coisa que aparece em exame (Sindicato dos trabalhadores) (CALEFFI, 2008, p. 64).

Para os trabalhadores informais, acometidos por doenças do trabalho, não há opção de saída temporária do mercado de trabalho para realizar os tratamentos necessários para a recuperação de sua saúde, porque eles não estão cobertos pela previdência. Em geral, boa parte dos trabalhadores terceirizados também tem pouca possibilidade de mobilidade profissional, 
devido à baixa escolaridade e à falta de oportunidades de formação e qualificação profissional ${ }^{48}$.

Nesse grupo de evidências também é possível destacar as formas utilizadas pelos empregadores para não prestar a devida assistência ao trabalhador adoecido. A primeira estratégia é a própria terceirização, em que a empresa contratante terceiriza as áreas de maior insegurança e risco à saúde, retirando de suas estatísticas os casos de doenças do trabalho. Outra estratégia das empresas é de não registrar a Comunicação de Acidente de Trabalho (CAT), documento oficial que reporta aos órgãos de fiscalização do trabalho os casos de doenças e de acidentes de trabalho. Para as terceiras, a não emissão de CATs é relevante porque o índice dessas comunicações abertas conta negativamente para fechar novos contratos (BARBOSA, 2013). É frequente também a tentativa das empresas de responsabilizar os trabalhadores quando são acometidos por alguma doença ou sofrem algum tipo de acidente. A forma mais cruel é a demissão do trabalhador, que convivendo com uma doença ou perda de membro, resultante da insegurança do trabalho, terá maiores dificuldades para reinserir-se no mercado de trabalho.

Trabalhadores da confecção, Criciúma, SC:

Trabalhadores que ficam de atestado médico, quando retornam recebem atribuições diferentes como forma de retaliação, e são os primeiros a serem demitidos. Quando ocorre acidente de trabalho, como quando uma costureira perfura o dedo, é comum o colega auxiliar ou chamar o mecânico para retirar a agulha com alicate, e não buscarem auxílio médico. Ignoram-se riscos de complicação com pequenos ferimentos (CALEFFI, 2008, p. 71).

Trabalhadores do setor de energia elétrica, Minas Gerais:

Este trabalho de averiguação permanente acaba se tornando ainda mais difícil, porque muitas vezes as empresas terceirizadas escondem ou não notificam aos órgãos competentes sobre algum acidente acontecido com um de seus funcionários (FIGUEIREDO, 2015, p. 38).

Trabalhadores da indústria Naval, Rio Grande, RS:

\footnotetext{
${ }^{48}$ No item Condições de trabalho iremos apresentar as informações sobre escolaridade e formação profissional.
} 
No entanto, nas relações entre empregados do estaleiro e empregados terceirizados, afirmou a entrevistada Antônia que a diferença existia e declara que "quando havia algum tipo de acidente ou incidente em que ambas as operações estivessem presentes [contratante e terceirizada], com certeza havia um jeito de culpabilizar a terceirizada" (SILVA, 2016, 121).

Por fim, trabalhadores e dirigentes sindicais denunciam as poucas ações realizadas para garantir a saúde e segurança dos trabalhadores: falta treinamento para o uso dos equipamentos de trabalho e para os equipamentos de proteção individual e coletivo; faltam políticas de promoção e proteção da saúde dos trabalhadores e equipamentos de segurança individual e coletiva; o ritmo de trabalho intenso e o cansaço físico ou mental extremo levam também à ocorrência de adoecimento e acidentes de trabalho; há o descumprimento das Normas Regulamentadoras (NR) relativas à saúde e segurança do trabalhador.

Trabalhadores de empresas fornecedoras de partes, peças e serviços para o setor Automotivo, Camaçari, BA:

Do mesmo modo, a operadora de uma sistemista destaca que seu acidente ocorreu devido à falta de treinamento para a execução de uma função nova, que foi introduzida por conta da produção de um novo modelo de veículo da montadora (BARBOSA, 2013, 201).

Trabalhadoras do asseio e conservação, Santa Maria, RS:

Evidencia-se que mesmo exposta a mais riscos no seu ambiente laboral (como riscos de contaminação), A. não recebe treinamento direcionado de como enfrentar e se proteger de tais riscos (ANDRETA, 2016; p. 175).

Trabalhadores do setor de petróleo e gás, São Francisco do Conde, BA:

Ainda neste quesito, chama a atenção o fato de que os terceirizados pouco responderam acerca da questão sobre os agentes nocivos, em comparação com os petroleiros. Disto destacamos que os trabalhadores terceirizados desconhecem, em sua maioria, os riscos presentes no ambiente de trabalho onde desenvolvem suas atividades (BRITO, 2014; p. 156).

Trabalhadores do tele atendimento, Curitiba, PR: 
Além disso, $38,24 \%$ dos trabalhadores disseram que se sentem cansados mentalmente ao final do dia de trabalho, $20,59 \%$ afirmaram que se sentem cansados física e mentalmente e apenas 5,88\% apresentam cansaço físico (MENDES, 2005, p.67).

No caso dos Equipamentos de Proteção Individual ou Coletiva (EPIs), além da falta de treinamento para o uso adequado, os relatos indicam também a baixa qualidade dos materiais, a falta de opções mais adequadas aos diferentes biótipos de trabalhadores e trabalhadoras, a demora em trocar os equipamentos já gastos e o não fornecimento deles.

Trabalhadores do setor de asseio e conservação, Santa Maria, RS:

A mão "cozida dentro da luva", relatada por N., é muito significativa, pois escancara a negligência com os equipamentos de proteção individual para as trabalhadoras terceirizadas do setor da limpeza, de forma que a adaptação e a reutilização fazem parte do cotidiano das trabalhadoras. Mas, mais do que isso, revela uma das consequências mais nefastas da falta de treinamento que é o contato inadequado com os produtos químicos (ANDRETA, 2016, p. 177).

Trabalhadores em empresas prestadoras de serviços para o setor de energia elétrica, Minas Gerais:

O eletricitário conta que não era desatento com a sua segurança e que, inclusive, chegou a avisar para os seus encarregados na empreiteira que necessitava de substituição de alguns EPIs (equipamentos de segurança individual) que já estavam bastantes gastos, mas a solicitação foi negada pelo pessoal da empresa. "No dia que eu sofri acidente, eu pedi para trocar minha botina. A botina que eu estava usando era eu quem tinha comprado. A luva que eu estava usando, eu pedi para trocar. No almoxarifado, eles falaram que dava para usar a luva mais uns 15 dias ainda. E ela estava toda furada." (FIGUEIREDO, 2015, p. 42).

Considerando esses elementos, a ocorrência de acidentes, fatais ou não, entre os trabalhadores terceirizados é maior do que entre os trabalhadores diretos, conforme os dados sistematizados em nossa análise. No caso dos acidentes fatais, é recorrente a indicação, nos estudos do setor automotivo, petroquímico e de energia elétrica, de que a estratégia das empresas contratantes é de terceirizar os postos com alto risco de vida. Além dos 
acidentes fatais, os ambientes de trabalho inseguros e insalubres, a falta de treinamento e de equipamentos de proteção, o intenso ritmo de trabalho - o que, enfim, expressa uma política de desvalorização da vida, repercute no aumento da incidência de acidentes como cortes e perfurações, perda de membros, queimaduras e mutilações de parte do corpo entre os trabalhadores terceirizados.

Trabalhadores em empresas fornecedoras de peças, partes ou serviços para o setor automotivo, São José dos Campos, SP:

Os acidentes, no entanto, resultam não apenas do aumento de ritmo, mas de outros fatores também, como do aumento da intensidade do trabalho, da falta de qualificação e treinamento do trabalhador terceirizado. Ao lado do problema do acidente no local de trabalho, a lesão do trabalhador constitui um dos maiores problemas, nem sempre percebido, embora sua ocorrência seja quase endêmica na fábrica (CASTRO, 2005; p. 58).

Indústria química, Curitiba, PR

Este trabalhador trabalha exposto a um ruído infernal e a uma alteração de temperatura que vai de 0 a 200 graus Celsius empregada no processo de fusão-refrigeração. Das quatro auxiliares de produção entrevistadas, todas já sofreram acidentes, ferimentos nas mãos, com os seus instrumentos de cortes, por exemplo. Uma perdeu três dedos de uma mão numa das máquinas, foram reimplantados, mas perdeu definitivamente os seus movimentos (DIAS, 1998, p. 103).

O setor de energia elétrica, com duas pesquisas, uma em Minas Gerais e outra no Paraná, apresenta inúmeros relatos de acidentes de trabalho, inclusive, fatais. A seguir, um trecho que descreve um desses acidentes:

Com apenas 19 anos na época e pouca experiência e tempo de serviço no seu primeiro trabalho, ele sofreu um acidente gravíssimo quando executava um reparo na rede de alta tensão, em maio de 2008. "Aquele dia está até hoje em minha cabeça. Eu sempre sonho com o acidente", relembra Douglas. O jovem eletricitário foi eletrocutado quando um fio de energia que deveria estar desligado para a realização do reparo esbarrou-se em sua perna, causando-Ihe queimaduras de terceiro grau em várias partes das pernas e coxas, além de mutilação genital e amputação da perna esquerda na altura da virilha. Além disso, devido à intensidade do choque, o trabalhador 
sofreu uma parada cardíaca e ficou internado por vários dias em estado grave de saúde (FIGUEIREDO, 2015, p.43).

Em um dos documentos analisados também é apresentada a relação entre o aumento da terceirização e a ocorrência de "acidentes ampliados", ou seja:

(..) eventos de magnitude como vazamentos, explosões e incêndios, envolvendo emissão de substâncias químicas e tóxicas (...) que trazem danos ambientais e podem vitimar os trabalhadores envolvidos, bem como trazer danos e impactos às populações circunvizinhas e aos ecossistemas locais, se espraiando no espaço e tempo (BRITO, 2014, p.25, apud FREITAS et al., 2000).

Segundo o autor, a ocorrência de acidentes ampliados nas refinarias de petróleo no país estava relacionada, em parte, ao processo de terceirização, com falta de treinamento adequado para os operadores indiretos da produção, dentre outros motivos. $\mathrm{O}$ autor destaca que as empresas envolvidas, a despeito dos fatores relacionados à decisão gerencial tanto da empresa contratante como da empresa terceira, frequentemente acusam os trabalhadores de imprudência.

O último código desse grupo, Assédio moral e sexual, aparece mais recentemente nas teses e dissertações sobre terceirização: a primeira dissertação que utiliza esse termo é de 2008 (CALEFFI, 2008), depois outra em 2009 (PEREIRA, 2009), e a partir de 2011 começa a aparecer com mais frequência nos documentos analisados. Nas teses e dissertações anteriores ao ano de 2008, o conteúdo do assédio moral e sexual aparece, mas sem essa nomenclatura. Em 1995, há o relato de assédio sexual sofrido por trabalhadoras terceirizadas da costura, no setor de confecção (GOULARTI FILHO, 1995).

Apesar de ser um tema mais recente, são bastante evidentes as formas de assédio moral contra as trabalhadoras e trabalhadores terceirizados, através de constrangimentos recorrentes para que não reclamem das condições de trabalho, inclusive, com ameaças de demissão, pressão constante para o cumprimento de metas de atendimento e produção, ofensas em relação à qualidade do trabalho e ao próprio trabalhador. Nos documentos que 
apresentaram evidências relativas a esse código, registramos dois casos de assédio sexual, um deles sofrido por uma trabalhadora do asseio e conservação por homens, servidores públicos do órgão federal em que trabalhavam (CHAGAS, 2014; 82). Mas também há relatos de formas de assédio moral, às quais as trabalhadoras e os trabalhadores estão submetidos, como demonstram os exemplos no setor de energia elétrica, no comércio varejista e na construção civil, destacados abaixo.

Trabalhadores em empresas prestadoras de serviço para o setor de energia elétrica, Minas Gerais:

(...) há inúmeras formas de assédio e constrangimento contra os trabalhadores na empresa, desde exposições públicas, brincadeiras e piadas vexatórias, até mesmo machismos contra as mulheres que fazem o serviço de limpeza, e coação contra trabalhadores que participam de reuniões chamadas pelo sindicato ou que leem o jornal oferecido pelo mesmo sindicato (FIGUEIREDO, 2015, p. 50).

Trabalhadores do comércio varejista, Palhoça, SC:

No mínimo duas vezes por semana tinha a tal da reunião. A gente era obrigada a ficar em pé. Teve uma que durou mais de duas horas. Era muita falação! Os gerentes reclamavam muito do nosso trabalho. Diziam que a gente não tava atingindo o padrão Renner e que se continuasse assim ia todo mundo pra rua. Que era preciso trabalhar mais porque ali não tinha lugar pra vagabundo! Outras vezes, diziam que o trabalho parecia ter sido feito por burros ou analfabetos. A gente aguentava tudo calada. $\mathrm{Ai}$ de quem falasse alguma coisa (PEREIRA, 2009, p. 88).

Trabalhadores da Construção Civil, Campinas, SP:

A pressão para aumentar a produtividade do trabalhador pode, por vezes, assumir feições de um assédio moral, no qual o trabalhador passa por situações de injúria, difamação, humilhação ou até mesmo perseguição no ambiente de trabalho (BARBOSA, 2013, p. 194).

De forma sintética, para podermos visualizar melhor as formas de precarização do trabalho terceirizado e seu impacto negativo para a saúde do trabalhador e sua abrangência, sintetizamos as informações no Gráfico 4, página 160. Dentre as 67 teses e dissertação estudadas, foram encontradas 
evidências de ocorrências frequentes de situações que precarizam as condições de saúde do trabalhador de forma contundente, inclusive com risco de vida, em 66,7\% das teses e dissertações analisadas. Em 12,2\% foram encontradas ocorrências que não acometiam todos os trabalhadores ou não eram frequentes. Em apenas 2,4\% das teses e dissertações analisadas os códigos relativos à precarização das condições de saúde do trabalhador estavam em consonância com as normas de saúde ou eram similares a dos trabalhadores diretamente contratados. Em 18,7\% dos documentos analisados (23 teses e dissertações) esse tema não foi abordado no trabalho de campo.

Nas teses e dissertações que foram objeto da RBS (tabela 10, página 161), 29 traziam informações sobre o ambiente de trabalho, 20 apresentavam informações sobre acidentes de trabalho, outras 23 avaliavam as doenças de trabalho dos terceirizados, 16 apresentavam dados sobre 0 uso dos equipamentos de proteção individual e coletiva, e outras 12 teses e dissertações investigaram a ocorrência de assédio sexual ou moral em seus estudos de campo. No eixo Saúde do trabalhador, a análise contou com 44 teses e dissertações, que apresentaram dados e informações primárias de um ou mais códigos pertinentes.

A precarização das condições de trabalho, que busca a redução dos custos do trabalho, resulta em processos laborais penosos e degradantes, e expõe os trabalhadores e as trabalhadoras ao adoecimento, acidente e mortes. Nesse campo, as implicações dizem respeito à capacidade de manutenção da força de trabalho de cada trabalhador e, portanto, de poder continuar se sustentando através de seu trabalho, e mais, diz respeito também à sua condição de vida em seu tempo livre. 


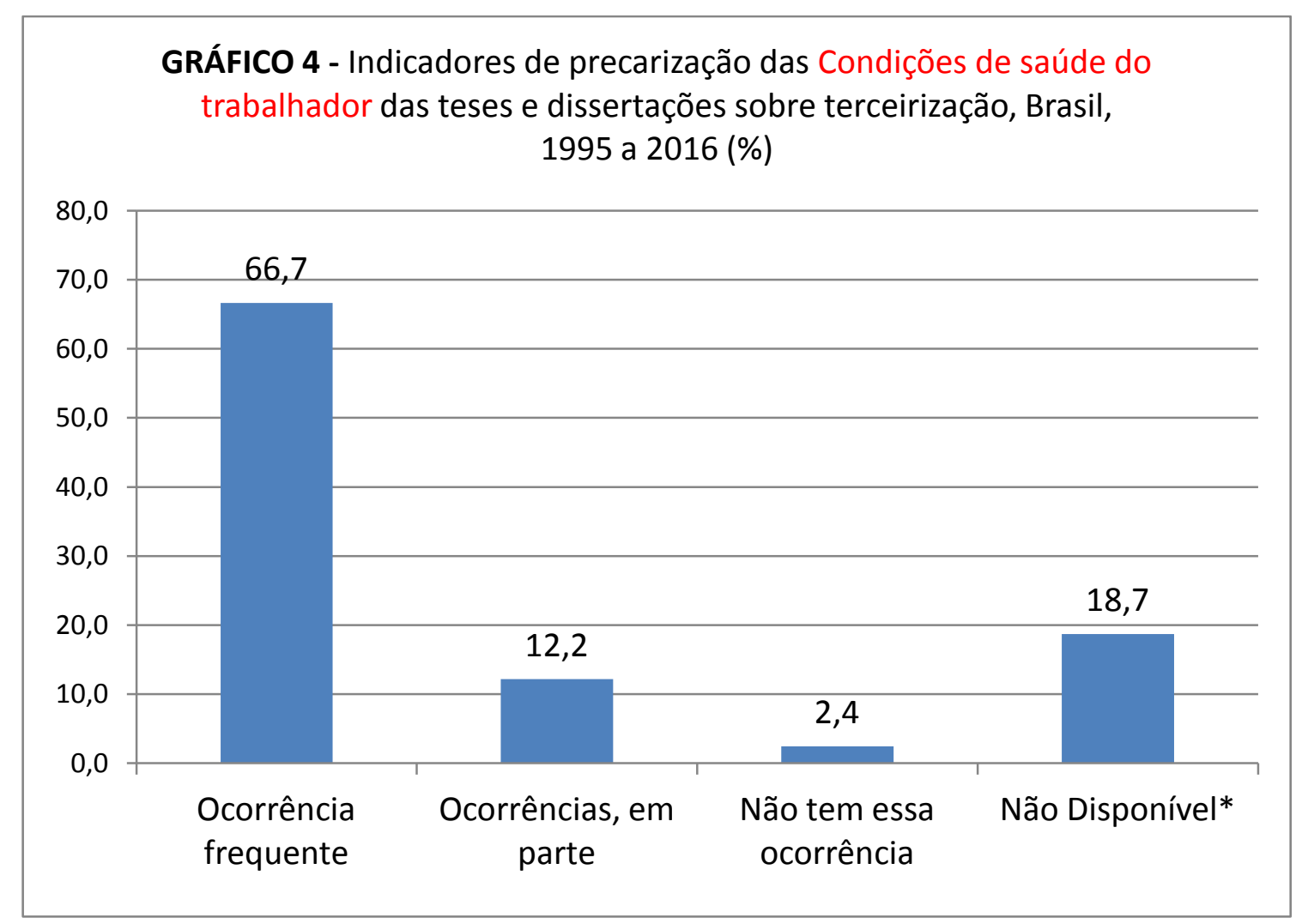

Fonte: RBS - Balanço da produção acadêmica sobre condições e relações de trabalho dos terceirizados, 2019. Elaboração da autora. *Não disponível: nas teses e dissertações estudadas esse tema não foi objeto de investigação na pesquisa de campo. 
TABELA 10 - Frequência dos indicadores de precarização do trabalho do eixo Saúde do Trabalhador presentes nas teses e dissertações sobre terceirização, Brasil, 1995 a 2016

\begin{tabular}{|c|c|c|c|c|c|}
\hline Tipo de ocorrência & $\begin{array}{c}\text { Problemas no } \\
\text { ambiente de } \\
\text { trabalho }\end{array}$ & $\begin{array}{l}\text { Recorrência e } \\
\text { risco de } \\
\text { Acidentes de } \\
\text { trabalho }\end{array}$ & $\begin{array}{c}\text { Recorrência e } \\
\text { risco de } \\
\text { Doenças de } \\
\text { trabalho }\end{array}$ & $\begin{array}{l}\text { Problemas de } \\
\text { qualidade e } \\
\text { acesso aos } \\
\text { Equipamentos } \\
\text { de segurança }\end{array}$ & $\begin{array}{l}\text { Ocorrências de } \\
\text { Assédio } \\
\text { sexual ou } \\
\text { moral }\end{array}$ \\
\hline Ocorrência frequente & 22 & 18 & 20 & 10 & 12 \\
\hline Ocorrências, em parte & 6 & 2 & 3 & 4 & 0 \\
\hline Não tem essa ocorrência & 1 & 0 & 0 & 2 & 0 \\
\hline Não Disponível & 38 & 47 & 44 & 51 & 55 \\
\hline Total & 67 & 67 & 67 & 67 & 67 \\
\hline
\end{tabular}

Fonte: RBS - Balanço da produção acadêmica sobre condições e relações de trabalho dos terceirizados, 2019. Elaboração da autora. *Não disponível: nas teses e dissertações estudadas esse tema não foi objeto de investigação na pesquisa de campo. 


\subsubsection{Ação coletiva e ação sindical}

Com o advento da revolução industrial, os sindicatos se tornaram a experiência mais importante das formas organizativas que os trabalhadores desenvolveram desde o século XIX, tanto em termos de defesa dos interesses imediatos dos trabalhadores, mas também em processos mais amplos, políticos e sociais em diversos países. Com as mudanças no padrão de acumulação capitalista houve mudanças também nos padrões econômicos, políticos, sociais e culturais, com implicações para o mundo do trabalho, que sofreu uma reconfiguração. Nesse novo cenário, os sindicatos têm enfrentado diversas dificuldades para mudar as estratégias organizativas e continuar a exercer o papel que tiveram durante certo período do século XX (Santana, 2015).

Há uma vasta produção acadêmica tratando das crises e impasses vividos pelo movimento sindical no período chamado de pós-fordismo ao redor do mundo. Leôncio Rodrigues (1999) faz uma abrangente revisão dessa literatura sobre esse período no livro "Destino do sindicalismo", sobretudo dos estudos que abrangem a América do Norte e a Europa. Nesse livro, o autor destaca como sintoma mais evidente dessa crise a queda na taxa de sindicalização, analisada a partir de um levantamento estatístico desde 1955. Dentre os principais efeitos da dessindicalização para o movimento sindical estaria a redução do poder sindical nas relações de trabalho, mas também na vida política e econômica dos países.

Um conjunto de fatores está relacionado a esse processo de dessindicalização, como a redução das bases de trabalhadores representada, devido à: a) introdução de novas tecnologias e de novas formas de organização da produção, como a terceirização; b) realocação territorial da produção e dos serviços; c) redução relativa e/ou absoluta do número de trabalhadores na indústria; d) mudanças nos sistemas de relações de trabalho nos diversos países; e) a proeminência de novos segmentos populacionais como jovens, mulheres e migrantes; f) heterogeneidade da mão de obra; g) 
privatizações e abertura comercial, especialmente nos países periféricos; e h) mudanças políticas no cenário mundial e em cada país. Esses elementos são destacados centrais para analisar as dificuldades que o movimento sindical tem enfrentado tanto para mobilizar os trabalhadores como para ampliar sua representatividade junto a estes; ou, ainda, para conquistar novos direitos, em especial a partir da década de 1980 no mundo e especificamente a partir da década de 90 no Brasil (LEÔNCIO RODRIGUES, 1999; WATERMAN, 1999; JACOME RODRIGUES, 2015).

É importante destacar que apesar dos autores concordarem com a variedade de fatores que têm impacto sobre 0 trabalho $e$ sobre as organizações de trabalhadores não há concordância sobre os efeitos dessas mudanças sobre a instituição "sindicato", sobre o movimento sindical e sobre a ação coletiva dos trabalhadores. Para Leôncio Rodrigues (1999), esse processo instala o declínio do movimento sindical, que deixa de ser 0 movimento mais dinâmico para as relações. Mas segundo Santana (2015), para outros estudiosos, essas mudanças resultam em uma crise para um determinado desenho de sindicato, e para superá-la é necessário repensar a ação e as estratégias sindicais, de modo a se manter como um movimento expressivo nas relações capital-trabalho, mas também nas relações mais gerais da sociedade.

Leôncio Rodrigues (1999) propõe uma classificação para os diversos fatores de mudança: aquelas de natureza socioeconômica, que seriam as de caráter mais estrutural e de mais longa duração com menores possibilidades de reversão; e em fatores de natureza políticos-institucionais, que podem ser definidos como aqueles que têm características mais conjunturais, de curta duração e com maior possibilidade de intervenção, e por fim, um terceiro grupo de fatores que apresentam mudanças culturais e valorativas.

Entre os fatores destacados como de natureza socioeconômica temos as "formas de organização da produção, mudanças tecnológicas, desemprego, deslocamento de indústrias, declínio de atividades econômicas, mudanças na composição profissional da mão de obra e sua distribuição por ramos, dimensão de empresas, mercado internacional" (LEÔNCIO RODRIGUES, 1999, p. 162). Dentre as formas de organização, destaca-se a terceirização, 
que resulta na fragmentação dos trabalhadores tanto do ponto de vista das reivindicações como espacialmente.

Os novos dilemas desse processo acometem os sindicatos e suas consequências também têm sido relatadas nas teses e dissertações; elas serão objeto de análise nesse tópico. Destacamos também além da ação sindical, o que chamamos de ação coletiva, ou seja, a atuação conjunta dos trabalhadores em torno de melhorias das condições e relações de trabalho, mesmo que sem a organização sindical como elemento aglutinativo.

No eixo Ação coletiva e ação sindical, temos como códigos os seguintes fatores: ação coletiva, ação sindical e práticas antissindicais. Destacamos nesse eixo os efeitos da terceirização para a organização dos trabalhadores e as formas de luta e resistência, tanto aquelas organizadas pela estrutura sindical, como aquelas que foram organizadas pelos trabalhadores sem a participação dos sindicatos. Em práticas antissindicais, destacamos as formas como as empresas atuaram para impedir a organização dos trabalhadores terceirizados e a ampliação de direitos.

QUADRO 9 - Códigos e evidências dos efeitos da terceirização sobre a Acão coletiva e a acão sindical

\begin{tabular}{|c|c|}
\hline Códigos & Evidências \\
\hline $\begin{array}{c}\text { Práticas } \\
\text { antissindicais }\end{array}$ & $\begin{array}{l}\text { - Ameaças de demissão em caso de participação em } \\
\text { paralisações, mobilizações ou greves; } \\
\text { - Descumprimento de acordos negociados com o sindicato; } \\
\text { - Impedimento de acesso dos dirigentes sindicais a local de } \\
\text { trabalho; } \\
\text { - Demissão de dirigentes sindicais; } \\
\text { - Tentativa de "comprar" a demissão de dirigente sindical; } \\
\text { - Pressão para não adesão às greves; } \\
\text { - Carta à família dos grevistas; } \\
\text { - Uso da força policial para dispersar manifestação; }\end{array}$ \\
\hline Ação coletiva & $\begin{array}{l}\text { - Dificuldades: } \\
\text { - Fragmentação em diversos locais de trabalho, dispersão; } \\
\text { geográfica, mas contratados por uma mesma empresa; } \\
\text { - Dificuldade de ação conjunta com os trabalhadores de } \\
\text { outras empresas terceirizadas; } \\
\text { - Dificuldade de ação conjunta com os trabalhadores da }\end{array}$ \\
\hline
\end{tabular}




\begin{tabular}{|c|c|}
\hline & $\begin{array}{l}\text { empresa contratante; } \\
\text { - Realização de atividade laboral de modo isolado (por } \\
\text { exemplo, asseio e conservação em prédios residenciais); } \\
\text { - Ex-trabalhadores, colegas de trabalho, familiares, sendo } \\
\text { novos patrões/empregadores; } \\
\text { - Sindicato pouco atuante entre as terceirizadas (atuam } \\
\text { mais entre as grandes empresas do setor); } \\
\text { - Rivalidade entre trabalhadores diretos e trabalhadores } \\
\text { terceirizados; } \\
\text { - Ações que superaram as dificuldades: } \\
\text { - Reivindicação e negociação direta de pautas com a } \\
\text { empresa, sem intermediação do sindicato; } \\
\text { - Greves e paralisações das atividades sem a intermediação } \\
\text { do sindicato; }\end{array}$ \\
\hline Ação sindical & $\begin{array}{l}\text { - Dificuldades: } \\
\text { - Alta rotatividade; } \\
\text { - Falso cooperativismo e impossibilidade de organização } \\
\text { sindical, segundo a Lei; } \\
\text { - Redução da base de representação/ relocalização da força } \\
\text { de trabalho; } \\
\text { - Manobras das empresas quanto ao registro de atividade } \\
\text { econômica e portanto, de representação sindical; } \\
\text { - Baixo conhecimento sobre a atuação sindical; } \\
\text { - Desconhecimento sobre o sindicato; desconhecimento } \\
\text { sobre a ação sindical; } \\
\text { - O sindicato não aprece no local de trabalho; } \\
\text { - Pautas distintas entre diretos e terceirizados; } \\
\text { - Baixa sindicalização; menor número de sindicalizados } \\
\text { entre os terceirizados, mesmo que pertençam a mesma } \\
\text { categoria majoritamente; } \\
\text { - Sindicato normatiza regras que são mais protetivas para } \\
\text { trabalhadores que estão em empresas maiores; } \\
\text { - Acordos do sindicato com a empresa sem chancela da } \\
\text { base de trabalhadores; } \\
\text { - Dificuldade entre os próprios dirigentes sindicais de } \\
\text { reconhecer o trabalhador terceirizado; } \\
\text { - Mesma categoria, mesmo local de trabalho, mas empresas } \\
\text { diferentes; } \\
\text { - Relaçães familiares ou de amizade na contratação } \\
\text { (confecção e calçados); } \\
\text { - Uma diversidade grande se sindicatos representando } \\
\text { trabalhadores que estão em uma mesma fábrica; } \\
\text { - Dificuldade de acesso ao local de trabalho; }\end{array}$ \\
\hline
\end{tabular}




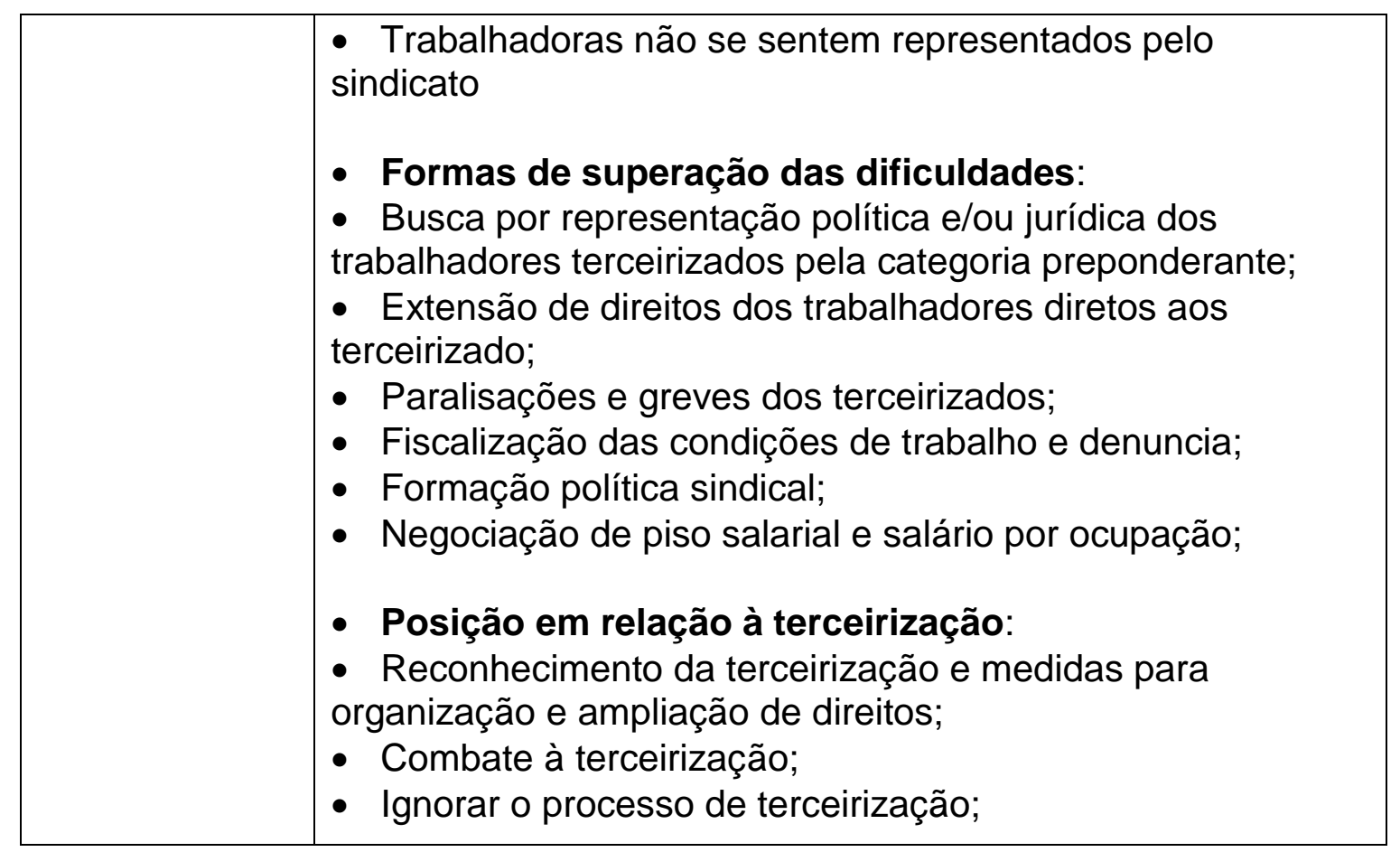

Fonte: RBS - Balanço da produção acadêmica sobre condições e relações de trabalho dos terceirizados, 2019. Elaboração da autora.

As práticas antissindicais é um dos temas que aparece com frequência na revisão bibliográfica, mas há poucas informações na pesquisa de campo. Dentre as ocorrências listadas temos a ação das empresas para pressionar os trabalhadores a não recolher as contribuições sindicais definidas em assembleia (SILVA, 2016). A carta de oposição ao desconto em folha deveria ser espontaneamente elaborada pelo trabalhador, mas em alguns locais, a própria empresa elabora a carta e constrange o trabalhador a assiná-la.

Em outra pesquisa, há o relato de como a empresa ameaça: utilizando os supervisores para pressionar os trabalhadores a não participarem dos sindicatos ou mesmo de qualquer mobilização coletiva no local de trabalho (FIGUEIREDO, 2015; PEDREIRA, 2015; LIMA, 2016). Em outro caso, a mobilização dos trabalhadores no interior da empresa foi um elemento destacado pelos trabalhadores para que a empresa de calçados iniciasse um processo de terceirização, fragmentando a produção (ALMEIDA, 2008).

Outro relato de prática antissindical foi a demissão de 55 trabalhadores terceirizados que entraram em greve por melhores condições de trabalho. Quando houve a reintegração de parte desses trabalhadores, teve inicio um 
processo de perseguição e até tentativa de "comprar" os trabalhadores para que pedissem demissão (SANCHES, 2006). Outro exemplo de tentativa de desmobilizar trabalhadores em greve foi no setor de teleatendimento através da pressão dos supervisores sobre os trabalhadores, de cartas para as famílias dos trabalhadores informando a participação de seus parentes na greve e do uso de força policial dentro do local de trabalho (CAVAIGNAC, 2010).

Em relação ao código Ação coletiva, achamos por bem separá-lo de ação sindical. Nos documentos analisados é frequente a ocorrência de ações coletivas que partiram das próprias trabalhadoras e trabalhadores, sem a participação dos sindicatos. Dentre os motivos, a distância do sindicato em relação aos terceiros ou a desconfiança dos trabalhadores em relação a sua representação sindical oficial, parecem ser os motivos mais recorrentes.

Quanto à dificuldade para organização de ações coletivas encontramos, como ocorrências, a fragmentação dos trabalhadores e trabalhadoras em diversos locais de trabalho, dispersos geograficamente, mas contratados por uma mesma empresa. Isso foi bastante presente entre as trabalhadoras do asseio e conservação. Algumas trabalham em empresas de médio porte, mas estão dispersas em diversos locais de trabalho, e sequer conhecem seus colegas de empresa. Essa fragmentação impede que realizem algum tipo de organização coletiva no nível da empresa que as contrata.

Há, ainda, trabalhadores que realizam suas atividades laborais de modo bastante isolado, como por exemplo, os trabalhadores e trabalhadoras do asseio e conservação em prédios residenciais. Nessas situações, há, no máximo, mais alguns trabalhadores no mesmo local de trabalho, o que dificulta qualquer ação coletiva, considerando que a ameaça de demissão em caso de qualquer tipo de organização coletiva de trabalhadores é frequente nas relações de trabalho no Brasil.

Outra dificuldade para a concretização da ação coletiva e/ou sindical é de realizar ações conjuntas com os trabalhadores de outras empresas terceirizadas no mesmo local de trabalho ou com os trabalhadores da empresa contratante. Parece haver um abismo intransponível nas relações pessoais cotidianas, marcadas por uma organização da produção e gestão de pessoas que promove a fragmentação dos trabalhadores e trabalhadoras e dissemina 
formas de discriminação que colaboram com a formação do "nós" e do "eles". Há também, é verdade, uma diferença de pauta de reivindicação dos trabalhadores terceirizados e dos diretos, como visto no caso dos trabalhadores terceirizados em atividades financeiras (SANCHES, 2006).

Em setores como o de confecção e de calçados o processo de terceirização fragmentou os trabalhadores em diversas pequenas empresas. Em muitos casos, o dono da empresa é um ex-trabalhador, um colega de trabalho, um parente da família ou ainda o próprio marido. Essas relações de proximidade dificultam a separação entre relações de trabalho e familiares, de amizade.

Nessas unidades produtivas não existe uma nítida separação entre capital e trabalho, o que dificulta a identificação deles próprios como empresários ou patrão e os próprios trabalhadores têm dificuldades de reconhecêlos como tal. Podemos dizer, nesse caso, que temos trabalhadores explorando trabalhadores, isso cria uma espécie de divisão entre os trabalhadores, que desemboca em fragmentação e desorganização da classe.

(...) Lá [na empresa] patrão é patrão e funcionário é funcionário; aqui não, aqui não tem patrão (ALMEIDA, 2008, p. 141).

No entanto, a despeito das dificuldades, há relatos de experiências de organização de mobilizações, de greves e de reivindicação direta de pautas com a empresa. Em um dos casos analisados, a trabalhadora relata que, mesmo sendo informal, quando nova negociação coletiva era realizada pelo sindicato representante legal categoria, elas cobravam do seu empregador a isonomia de direitos. Em entrevistas, Lima (2009, p. 236) obteve os seguintes depoimentos:

"Eu não sou registrada aqui em Japurá, mas cobro da facção tudo que fico sabendo que as costureiras de Cianorte conquistaram. Quando posso, passo no sindicato para saber o que preciso cobrar" (Entrevista, Japurá, junho/2006).

Uma de nós sempre vai a Cianorte para buscar roupas e aproveita para saber sobre a situação de nosso piso salarial (Entrevista, Tuneiras do Oeste, junho/2006).

Não sou do sindicato, mas fico por dentro de tudo que as costureiras conseguem nas negociações em Cianorte. Se 
eu morasse mais perto iria nas reuniões, mas se eu sair daqui par ir,perco um dia inteiro de trabalho (Entrevista, Tuneiras do Oeste, junho/2006).

Em outro caso, em uma universidade pública, as trabalhadoras se dirigiam ao supervisor funcionário da instituição, para que tomasse as providências em relação as suas reclamações, em geral, relativas ao atraso de salários (BARROS, 2015). Em uma cooperativa, as trabalhadoras pararam a produção, quando perceberam que o regime de trabalho era uma relação de assalariamento disfarçado e que os benefícios prometidos por ser uma cooperada não estavam sendo cumpridos (AMORIM, 2003).

Analisando as ocorrências relativas à ação sindical, agrupamos a diversidade de evidências em três grupos:

- Aquelas que apontam dificuldades externas ao movimento sindical, relativas à ação das empresas, da legislação, do mercado de trabalho nacional;

- Outro grupo diz respeito à falta de atuação sindical e desconhecimento dos trabalhadores sobre o sindicato;

- Um terceiro grupo aponta as dificuldades que a organização do trabalho e a estrutura sindical impõem para a organização dos trabalhadores.

No primeiro grupo está presente a alta rotatividade do mercado de trabalho. A todo o momento, parte significativa da mão de obra é demitida, novos trabalhadores são contratados, e o sindicato precisa reconstruir ações de organização dos novos trabalhadores.

Outra evidência presente nas teses e dissertações foram as falsas cooperativas que, pela sua natureza de trabalho, não prevê organização sindical dos cooperados. A disseminação desse modelo a partir dos anos 1990, com uma nova legislação que facilitava o uso indiscriminado, inclusive como intermediação de mão de obra, foi objeto de estudo em 10 teses e dissertações aqui analisadas. Em todas elas o objetivo na utilização das cooperativas era que elas fossem uma forma de terceirizar a força de trabalho para reduzir custos. Os sindicatos tinham dificuldade de atuar, pois o desdobramento de 
muitas ações resultava no fechamento das falsas cooperativas e na demissão dos trabalhadores e trabalhadoras.

Outra dificuldade relatada era a redução da base de representação em função da desverticalização ou relocalização das empresas e, ainda, da alta taxa de desemprego (anos 1990 e anos 2000) e a respectiva redução da base de representação e sindicalizados. Algumas empresas também realizam manobras quanto ao registro de atividade econômica, alterando a categoria que seria a responsável pela representação sindical dos trabalhadores, por exemplo, ao invés da empresa de prestação de serviços, com uma atividade tipicamente metalúrgica cadastrar sua atividade econômica nesse setor, registrava como construção civil, serviços gerais, logística, entre outros, para evitar categorias representadas por sindicato mais atuantes e com maior abrangência de direitos negociados.

O segundo grupo diz respeito à falta de atuação das entidades sindicais. $\mathrm{Na}$ avaliação dos trabalhadores, segundo parte dos estudos analisados, os sindicatos de suas categorias tinham uma baixa atuação ou uma atuação equivocada em relação às trabalhadoras e trabalhadores terceirizados. Ocorrência relevante também foi observada em relação à falta de presença do sindicato no local de trabalho.

Em algumas teses e dissertações as evidências demonstraram um baixo conhecimento dos trabalhadores em relação à atuação do sindicato que os representava. Alguns trabalhadores sequer sabiam qual era a entidade representativa da sua categoria; ou, se sabiam qual era o sindicato, desconheciam qualquer ação que tivessem feito em relação àquela categoria (ANDRETA, 2016; BRITO, 2014). Em um caso no qual o sindicato representava os trabalhadores diretamente contratados pela tomadora e também representava os trabalhadores terceirizados, a pauta de reivindicação apresentada pelo sindicato para as empresas representava apenas as demandas dos trabalhadores diretos (SANCHES, 2006). Houve um estudo, sobre os trabalhadores do transporte de carga, que destacou um elemento importante em relação à atuação sindical de terceirizados: a realização de acordos do sindicato com a empresa sem chancela da base de trabalhadores (OLIVEIRA, 2014). O resultado dessas ações, ou da falta de ações que de fato 
represente os anseios dos trabalhadores terceirizados, é uma baixa participação desses na vida sindical e uma baixa sindicalização.

Em mais de um estudo no setor bancário, aponta-se que há certa "reclamação" com a postura dos trabalhadores terceirizados, que não participam das greves promovidas pela categoria preponderante. Mas, porque os trabalhadores terceirizados iriam parar pelas reivindicações de outras categorias? Enquanto suas condições de trabalho são mais precárias e suas demandas não estão na pauta? O trecho a seguir ilustra esse conflito:

Tomemos, por exemplo, a paralisação de um centro administrativo de um banco, na qual os trabalhadores terceirizados se recusam a participar, pois não se sentem envolvidos com o movimento. Afinal, o empregador não é o mesmo para todos e os seus direitos são ditados por contratante diferentes que, por sua vez, não repassam possíveis conquistas que o grupo dos bancários venha a ter (SANCHES, 2006, p. 122).

Considerando a estrutura sindical oficial, também foram encontradas evidências relacionadas à grande diversidade de sindicatos que representam os diversos trabalhadores/categorias que executam sua atividade laboral em uma mesma fábrica (CASTRO, 2005; ALMEIDA, 2013). Os dirigentes sindicais também relatam a dificuldade de acesso ao local de trabalho, considerando que as empresas utilizam diversas manobras para que o sindicato não possa acompanhar e fiscalizar o ambiente de trabalho.

Dentre as formas de superação das dificuldades enfrentadas pelos sindicatos para organizar as trabalhadoras e os trabalhadores terceirizados, elas se demonstraram pouco eficientes, até o momento, apesar de pontualmente registrarem vitórias tanto no que diz respeito aos direitos quanto do ponto de vista organizativo dos terceirizados. Uma das primeiras ações do movimento sindical foi à tentativa de impedir a terceirização via ação judicial, isto porque muitos desses processos aconteciam à revelia da legislação existente até 2017, com contratação de trabalhadores terceirizados em atividades fim ou ainda, com o uso de empresas terceirizadas que apenas funcionavam como interposição da mão de obra. Se em alguns setores ou empresas isso possibilitou a reversão da terceirização (e em alguns casos, a demissão dos terceirizados, que enxergaram no sindicato um agente que o fez 
perder o emprego, como na dissertação de Amorim, 2003), na maior parte, os processos a terceirização seguiu forte e se ampliou.

Outra ação sindical presente nos documentos analisados foi a de buscar representar politicamente e/ou juridicamente os trabalhadores terceirizados. $\mathrm{Ou}$ seja, realizar atividades, mobilizações, greves, pauta em conjunto ou específicas para os terceirizados, mesmo sem a representação oficial dos terceiros (CAVAIGNAC, 2010, Teleatendimento Fortaleza, CE). De outro lado, houve também a tentativa de ampliar os estatutos sindicais para que as empresas terceiras estivessem na base se representação sindical, como no caso de parte dos sindicatos de bancários filiados à CUT que utilizou esse recurso para representar os trabalhadores terceirizados em atividades do ramo financeiro e não apenas bancários (SANCHE, 2006). Outra experiência foi registrada no Polo Naval do Rio Grande, RS, onde foi ajustado entre as partes que todos os trabalhadores ali presentes seriam considerados metalúrgicos "excluídas as categorias organizadas cujos sindicatos viessem defender os trabalhadores a ela vinculados e dos serviços de apoio como vigilantes, alimentação e limpeza" (SILVA, 2016, p.133).

Os sindicatos das categorias preponderantes procuraram também negociar a extensão de direitos para os trabalhadores terceirizados, seja numa tentativa de igualar as condições de trabalho com os diretamente contratados, seja para avançar nos direitos dos terceiros, ainda que isso não representasse a igualdade de direitos. Por exemplo, uma experiência é a do polo naval do Rio Grande, RS:

Para tentar eliminar diferenças salariais, o STIMMMERG mapeou as atividades dos trabalhadores no Polo Naval utilizando uma tabela de funções e salários já existente: "Nós não oficializamos, ela não tem um gênero oficial, mas ela foi protocolada no Ministério do Trabalho e a gente entrega para as empresas que vem trabalhar aqui e informa que eles têm que cumprir aquele mínimo que está ali" (SILVA, 2016, p.138).

Por fim, os sindicatos das categorias preponderantes também listaram ações como a fiscalização das condições de trabalho dos terceirizados e denúncia junto aos órgãos públicos sobre condições precárias de trabalho ou 
violação de direitos. Também foi encontrada nas teses e dissertações a execução de cursos de formação em política sindical para terceirizados.

Marcelino (2008) em sua tese "Terceirização e ação sindical: $A$ singularidade da reestruturação do capital no Brasil" destaca que a ação sindical dos trabalhadores terceirizados está bastante atrelada a atual estrutura sindical brasileira que, em conjunto com todos os outros fenômenos presentes na esfera do trabalho, resulta em um quadro nada favorável para o movimento sindical. Segundo Marcelino (2008, p. 310) :

Uma resposta efetiva para essa realidade deveria passar por uma reestruturação sindical, por uma nova forma de organizar os trabalhadores, diferente daquela construída pelo corporativismo da era Vargas. Se a classe trabalhadora nunca foi homogênea, diante da especificidade da sua atual condição, o sindicalismo tem respondido com um esforço de manutenção ou, no mínimo, com o imobilismo da estrutura sindical e sua dificuldade em incorporar numa ação de enfrentamento as categorias precarizadas. O resultado concreto disso é a criação de barreiras para a condução de lutas unificadas e, no limite, para a construção da consciência que faz um trabalhador enxergar no outro um aliado na luta para acabar com qualquer forma de dominação de classe.

Mesmo os sindicatos com uma postura atuante para representar e organizar as trabalhadoras e trabalhadores, em que suas lutas políticas foram exitosas e relevantes para superar a fragmentação dos trabalhadores e para construir uma identidade de classe e uma atuação sindical potente enfrentaram problemas. Esses sindicatos acabaram esbarrando, em algum momento, nos limites da estrutura sindical, que não permite a livre organização dos trabalhadores em sindicatos que melhor os represente.

Ainda, como desdobramento das ações desenvolvidas pelo movimento sindical para representar ou ampliar direitos para as trabalhadoras e trabalhadores terceirizados, é importante registrar três posições relativas à terceirização que apareceram nas evidências colhidas nas teses e dissertações:

1. Reconhecimento da terceirização e medidas para organização e ampliação de direitos: apesar de eventualmente combater processos de terceirização, consideram o processo sem reversão; resta ao 
movimento sindical procurar formas de organizar esses trabalhadores e suas pautas, ainda que em condições menos favoráveis que a dos trabalhadores diretos.

2. Ignorar o processo de terceirização: sindicatos que continuam voltados para os trabalhadores diretos e que em suas falas registram a impossibilidade, devido à estrutura sindical brasileira, de organizar e representar os trabalhadores terceiros; ou ainda, sindicatos que representam trabalhadores terceirizados e não os enxergam como terceiros - desse modo, acabam não atuando para eliminar as desigualdades presentes nessa relação de trabalho.

3. Combate à terceirização: combate ao processo de terceirização, denunciando os efeitos negativos de para os trabalhadores.

Barbosa (2013), em sua dissertação " $A$ hierarquia da precarização - a terceirização em cascata no Complexo Automotivo Baiano" reflete sobre a diferença do alcance da atuação sindical:

Como se vê a capacidade de luta por melhorias de condições de trabalho possui feições diferenciadas ao longo da cadeia produtiva, sugerindo uma hierarquia da ação sindical. Se a atuação dos sindicatos tende a se fragmentar e enfraquecer à medida que se desloca nos níveis inferiores da cadeia, a tendência é que persista a distância das condições de trabalho entre as pontas da cadeia, dilatando ainda mais a hierarquia da precarização. Contudo, a história não está determinada. (...) O desafio que se coloca para o movimento sindical é promover ações que busquem criar novas bases de identidade e solidariedade coletiva entre os trabalhadores dos diversos níveis da pirâmide produtiva, a fim de que as conquistas sejam partilhadas entre todos operários (BARBOSA, 2013 p. 207 e 208).

Considerando as informações disponíveis nas teses e dissertações analisadas, não foi possível construir indicadores sobre a terceirização e ação sindical ou ação coletiva. Em muitos estudos, assim como relatado acima, há considerações sobre a atuação sindical nos capítulos teóricos ou de revisão bibliográfica, mas em alguns documentos, o sindicato sequer foi procurando para entrevistas. 


\subsection{Terceirização e a hierarquia da precarização - um recorte setorial}

Nossa pesquisa buscou, ao longo de toda a dissertação aqui apresentada, destacar as relações e condições de trabalho das trabalhadoras e dos trabalhadores terceirizados, através da sistematização dos documentos que tratam desse tema. Com esse processo, buscamos responder às seguintes questões: (1) Quais são as formas mais recorrentes de trabalho precário tanto do ponto de vista dos contratos como das condições e relações de trabalho - utilizadas nos processos de terceirização?(2) Qual o alcance do processo de terceirização como um dos principais componentes da precarização do trabalho no Brasil, considerando a perspectiva setorial e geográfica? (3) É possível afirmar que os processos de terceirização, se bem aplicados como sugerem alguns manuais, não resultem em precarização do trabalho?

No decorrer da análise até o presente momento destacamos diversos indícios que respondem a primeira questão:

- As evidências e frequência das ocorrências demonstram que há uma variedade de formas de precarização que é facilitada pela terceirização, que passa por condições ambientais de trabalho insalubres que acometem os terceirizados a problemas de saúde e risco de acidentes, inclusive fatais;

- Condições de trabalho em que a tônica é a redução do custo do trabalho com os terceirizados, através de salários menores (diretos e indiretos), ampliação e intensificação da jornada de trabalho, violação de direitos, etc.;

- Facilita a combinação da terceirização e de uma variedade extensa de contratos de trabalho precários;

- Promove a fragmentação dos trabalhadores e mantém uma ação, coordenada pelas empresas, que limita a ação sindical e que se soma aos limites da nossa estrutura sindical.

Em relação à questão 2 (Qual o alcance do processo de terceirização como um dos principais componentes da precarização do trabalho no Brasil?) 
como dito no capítulo 2, as estatísticas do mercado de trabalho, apesar de possibilitarem uma análise nacional, possuem limites para a observação desse fenômeno. Por outro lado, os estudos de caso, que conseguem analisar com detalhes relevantes como se dá a terceirização, seus desdobramentos, seus efeitos para os trabalhadores e para as suas organizações sindicais, tem um olhar fragmentado - no sentido de voltado ao caso, com possibilidades limitadas de generalização das conclusões. Nosso objetivo foi sistematizar e analisar todas essas informações através de um método cientifico para construir um painel mais geral. O resultado não deixa sombra de dúvida: em todos os estudos, em todos os setores, em todas as regiões do país, a terceirização, quando analisada sob a ótica dos efeitos para aqueles que trabalham, resulta em forte precarização, em condições de trabalho significativamente piores do que as encontradas entre os trabalhadores diretamente contratados pela "empresa-mãe". Muitos autores e autoras, apoiados em quantidade maior ou menor de bibliografia, tinham já apontado essa conclusão: DELGADO (1994), LEITE (1997), DRUCK (1999), RAMOS (2001), SILVA (2001), CARRELI (2007), RAMALHO (2009), DAU e CONCEIÇÃO (2009), ANTUNES E DRUCK, 2013; DIEESE, 2011, entre outros. Nossa pesquisa, acreditamos, reforça de maneira definitiva essa tese, com a consolidação, pela primeira vez em nível de pós-graduação, de um balanço geral das teses e dissertações produzidas sobre o tema da terceirização.

Também constatamos que não é possível afirmar, passados mais de duas décadas de implantação da terceirização no Brasil, e com todas as evidências presentes nas teses e dissertações desse período aqui analisadas, que o fato da terceirização resultar em precarização do trabalho seja resultado de uma "aplicação equivocada" desse modelo de organização das empresas (nossa $3^{\text {a }}$ questão). Aliás, a terceirização é um duplo ganho para as empresas: (1) reduz o tempo de produção, de capital imobilizado, compartilha investimentos e desenvolvimento de novos projetos com uma diversidade de empresas/investidores; (2) de outro lado, reduz o custo da mão de obra, com os diversos mecanismos aqui apresentados de precarização do trabalho terceirizado e com fragmentação dos trabalhadores e de suas representações sindicais, além da externalização dos conflitos com a força de trabalho. 
Como resume Brito (2014, p. 134), a terceirização é uma estratégia para ampliar lucros e as empresas prestadoras de serviço devem seguir essa orientação com a diminuição de custos (EPIs de menor qualidade; economizar nos serviços de alimentação, transporte, assistência médica de baixa qualidade aos trabalhadores). Na diminuição de custos também está incluído burlar sistematicamente o cumprimento dos direitos trabalhistas de seus empregados, inclusive, através da "falência" da empresa. Dessa forma, a terceirização estabelece uma receita própria de deterioração das condições objetivas do estatuto do trabalhador terceirizado.

Como desdobramento dessas questões, em especial dessa última, também apresentamos na introdução da presente dissertação nossa hipótese: de que os processos de terceirização têm a tendência à precarização, mas é possível encontrar graus variados a depender: (1) do lugar na cadeia de fornecimento que a empresa terceira ocupa e (2) do nível de organização dos trabalhadores - e que esses graus diferentes são utilizados para justificar que pode existir uma "boa aplicação" e uma "má aplicação" da terceirização.

Nessa seção, buscaremos elementos presentes na Revisão Bibliográfica Sistemática (RBS) que possam colaborar com a avaliação de nossa hipótese. Para isso, iremos fazer outro recorte dos dados, a partir das evidências codificadas, considerando o cruzamento dos setores e dos códigos.

A Tabela 11 (na página 181) apresenta o número de códigos relacionados aos quatro eixos analisados no capítulo 3 (Saúde do trabalhador, Contrato individual de trabalho, Condições de Trabalho, Ação coletiva e ação sindical), distribuídos segundo os setores de atividade econômica. Essa tabela não expressa a quantidade de vezes que cada código aparece nas teses e dissertações, como nas análises apresentada nas seções anteriores. A tabela apresenta quantos códigos, dos 30 descritos ao longo da dissertação, estão presentes em cada setor de atividade, lembrando que cada código representa uma determinada forma de precarização do trabalho. Sendo assim, quanto maior o número de códigos, concluímos ser maior a presença de formas de precarização do trabalho no setor destacado. Lembrando também que o quadro não tem pretensão amostral, trata-se de um painel, a partir das informações presentes nas teses e dissertações. 
Entre os setores com maior número de códigos (acima de $20^{49}$ ) estão aqueles com maior grau de precarização do trabalho: confecção (25 códigos de precarização), asseio e conservação (23 códigos de precarização), calçados (22 códigos de precarização), atividades financeiras (20 códigos de precarização), prestadores de serviço no setor de energia elétrica (20 códigos de precarização) e teleatendimento (20 códigos de precarização). Podemos dividir estes setores em dois grupos com características distintas.

O primeiro o grupo dos setores de confecção, asseio e conservação ${ }^{50} \mathrm{e}$ calçados, conta com um número maior de temas relativos à precarização, decorrentes da presença de diversos contratos de trabalho precários, de informalidade, das piores formas de trabalho (escravo e infantil), de baixas remunerações, de benefícios de baixa qualidade ou de sua inexistência, altas jornadas, violação de direitos (principalmente no momento da rescisão), dificuldades de organização sindical, entre outros elementos. Esses temas (códigos) aparecem de forma recorrente nas pesquisas analisadas e abrangem a maior parte dos trabalhadores. Destaca-se também que esse processo de precarização é ainda mais invisibilizado pela terceirização em cascata ou quarteirização (no caso de calçados e confecção), no qual os processos de produção são repassados para empresas que subcontratam outras empresas uma ou mais vezes, repartindo o processo produtivo em pequenas partes ou ainda utilizando empresas de intermediação de mão de obra ao longo da cadeia produtiva. Nesse grupo, a força de trabalho, em sua grande maioria, é composta de mulheres, especialmente nos setores de confecção e de asseio e conservação.

O segundo grupo é composto pelos setores de atividades financeiras, prestadores de serviço no setor de energia elétrica e teleatendimento. Esse grupo tem vários temas em comum com o primeiro grupo destacado, com exceção dos contratos precários de trabalho, que aparecem com menor frequência. São trabalhadores de empresas terceirizadas ligadas a grandes contratantes. Apesar dos setores contratantes terem tradição relevante na

\footnotetext{
${ }^{49}$ Essas faixas foram organizadas apenas para facilitar nossa leitura em relação aos dados.

${ }^{50}$ Dos 12 estudos sobre asseio e conservação, em 11 a prestação de serviços é na administração pública, direta ou indireta, especialmente em escolas da rede estadual ou em universidades.
} 
organização sindical brasileira, os terceirizados estão alocados em empresas com registro de atividades econômicas de sindicatos com menor tradição de organização sindical. Esse é o caso, por exemplo, no setor energia elétrica, em que as empresas terceirizadas estão cadastradas como construção civil ou como serviços.

No caso do setor de energia elétrica os acidentes e acidentes fatais são mais recorrentes justamente nos postos de trabalho terceirizados. As atividades financeiras estabelecem condições de trabalho bastante distintas dos diretamente contratados pelos bancos, especialmente no que diz respeito ao salário e a jornada de trabalho. $O$ teleatendimento é formado por grandes empresas, mas isso não significa melhores condições de trabalho. Nesse caso os destaques são o alto ritmo de trabalho, o grande índice de adoecimento de trabalhadores com as chamadas LER/DORTS e também de doenças ligadas à saúde mental.

$\mathrm{Na}$ sequência, com uma frequência que vai de 15 a 19 códigos de precarização do trabalho, temos as empresas fornecedoras do setor automotivo (19 códigos de precarização), a indústria química e petroquímica (18 códigos de precarização), o setor de serviços (18 códigos de precarização), e depois, com 15 códigos de precarização cada, temos a administração pública direta, a saúde pública e a indústria metalúrgica.

O setor que fornece partes, peças e serviços para o setor automobilístico tem uma nítida separação nas condições de trabalho daqueles que estão no primeiro nível de fornecedores comparando com os de segundo e terceiro nível, quanto mais distantes do primeiro nível de fornecimento, mais precárias as condições de trabalho e maiores as dificuldades para a atuação coletiva e sindical dos trabalhadores. Esse elemento esteve presente nos quatro estudos sobre o processo de terceirização no setor automotivo.

A indústria química e petroquímica tem grande presença de temas como acidentes de trabalho, fatais ou não, problemas relativos à remuneração, à violação de direitos e à ação sindical. Apesar de haver uma variedade de setores de atividade econômica terceirizados, parte das empresas terceirizadas tem seus trabalhadores representados pelos sindicatos preponderantes na categoria (Químicos e Petroleiros). Os estudos sobre a indústria química e 
petroquímica também indicam que a precarização se amplia à medida que as terceirizadas estão fora dos muros das tomadoras ou, mesmo estando dentro da tomadora, se tem como setor aquelas atividades de menor conteúdo tecnológico.

No setor de serviços, contratos precários como cooperativa, rotatividade, remuneração e violação dos direitos são os temas da precarização mais frequentes.

$\mathrm{Na}$ administração pública direta e saúde pública há frequentes denúncias de discriminação e assédio moral ou sexual, rotatividade devido à falta de estabilidade dos terceirizados, diferenças de jornada, especialmente na saúde, além das diferenças salariais entre diretos e indiretos. No setor público estão serviços terceirizados de tecnologia da informação, serviços prestados no DETRAN do Rio de Janeiro e terceirização de trabalhadores do ensino médio e superior no CREAS (Centro de Referência Especializado em Assistência Social). $\mathrm{Na}$ saúde, os estudos analisam os impactos da terceirização para os trabalhadores da saúde, geralmente com formação em nível técnico e superior.

Nos setores com menos de 10 códigos de terceirização há uma variedade de situações: em alguns, é mais presente as violações relativas à jornada de trabalho (transporte), em outras, condições de trabalho e saúde (construção civil). 
TABELA 11 - Setores de atividade econômica das empresas terceirizadas ${ }^{51} \mathrm{e}$ frequência de códigos de precarização do trabalho terceirizado

\begin{tabular}{|c|c|c|}
\hline Setores & $\begin{array}{c}\text { Número de temas } \\
\text { de precarização } \\
\text { presente em cada } \\
\text { setor } \\
\text { (Número de } \\
\text { códigos) }\end{array}$ & $\begin{array}{l}\text { Número de tese e } \\
\text { dissertação em } \\
\text { cada setor } \\
\text { analisado }\end{array}$ \\
\hline Confecção & 25 & 7 \\
\hline Asseio e conservação & 23 & 12 \\
\hline Calçados & 22 & 3 \\
\hline Atividades financeiras & 20 & 6 \\
\hline $\begin{array}{l}\text { Prestadores de serviço no setor } \\
\text { de Energia elétrica }\end{array}$ & 20 & 2 \\
\hline Teleatendimento & 20 & 4 \\
\hline $\begin{array}{l}\text { Fornecedores do setor } \\
\text { automotivo }\end{array}$ & 19 & 4 \\
\hline $\begin{array}{l}\text { Indústria química e } \\
\text { petroquímica e fornecedores } \\
\text { dessa indústria }\end{array}$ & 18 & 6 \\
\hline Serviços & 18 & 9 \\
\hline Administração pública & 15 & 5 \\
\hline Saúde pública & 15 & 6 \\
\hline Indústria metalúrgica & 15 & 4 \\
\hline Indústria Naval & 13 & 3 \\
\hline Comércio varejista & 10 & 1 \\
\hline Construção Civil & 11 & 2 \\
\hline Transporte de cargas & 11 & 1 \\
\hline Educação privada & 8 & 1 \\
\hline Indústria & 7 & 2 \\
\hline Saúde privada & 5 & 2 \\
\hline Correios & 3 & 1 \\
\hline
\end{tabular}

Fonte: RBS - Balanço da produção acadêmica sobre condições e relações de trabalho dos terceirizados, 2019. Nota: algumas pesquisas estudam mais de um setor de atividade econômica. Elaboração da autora.

O recorte dos códigos/temas em uma perspectiva setorial facilita nossa leitura de como o processo de terceirização pode possuir graus distintos a depender do setor de atividade econômica ao qual está ligado, conforme destacado em nossa hipótese. Não foi possível averiguar de forma definitiva

\footnotetext{
${ }^{51}$ Nesse caso, destacamos como setor público porque a terceirização se deu em ocupações próprias do setor público. Em outros casos, como asseio e conservação e serviços prestados para a administração, publica direta ou indireta, eles foram classificados nos setores de atividade econômica da empresa terceirizada.
} 
como todos os setores terceirizados aqui investigados estão alocados em suas respectivas cadeias produtivas ${ }^{52}$. Alguns estudos, especialmente sobre os prestadores de serviços no setor automotivo e químico/petroquímico, destacam que diferentes graus de precarização da terceirização estão presentes na cadeia produtiva: quanto mais próximos da empresa tomadora, fisicamente e no compartilhamento de investimentos e desenvolvimento de projetos, menos precarizados; quanto mais distantes do elo principal da cadeia produtiva, da tomadora que integraliza a produção, e quanto menor a capacidade tecnológica da prestadora de serviços, ainda que esteja fisicamente próxima, maior a precarização fruto dos processos de terceirização.

Nesses setores também é possível destacar que, em alguns casos, quando as prestadoras de serviço têm como atividade econômica a mesma da tomadora e que, portanto, seus trabalhadores estão cobertos pela mesma representação sindical e pela mesma Convenção Coletiva de Trabalho, há menor precarização do trabalho. No entanto, essa não é uma regra, como supomos na hipótese. Depende da fase do processo produtivo que foi terceirizada e de outros fatores, como a posição sindical em relação à terceirização, além da capacidade organizativa e de mobilização do sindicato em questão.

Dias (2010), em sua dissertação de mestrado relata que os trabalhadores têm a percepção de uma hierarquização das diversas empresas terceirizadas que atuam dentro da CSN (Companhia Siderúrgica Nacional), em Volta Redonda, RJ. Essa hierarquização é construída considerando a ascensão profissional, mas que também é expressão de melhores condições de trabalho e menor discriminação. Se trabalhar na empresa-mãe, a CSN, é mais difícil, vislumbram melhorar sua posição interna através de oportunidades em empresas terceirizadas melhor avaliadas nesse "circuito off" (Dias, 2010, p.91).

De todo modo, é possível afirmar que há diferenças em como a terceirização ocorre, a depender do setor de atividade, se o trabalhador está

\footnotetext{
${ }^{52}$ Poucas pesquisas analisadas trazem recortes que consideram a cadeia produtiva.
} 
dentro ou fora da empresa. Nesse sentido, é possível afirmar que encontramos graus variados de precarização.

No que diz respeito à distribuição geográfica, a precarização está diretamente relacionada ao setor de atividade econômica predominante na região e também à formação da força de trabalho loca, bem como da préexistência ou não de um movimento sindical mais organizado.

A ação sindical como elemento que pode influenciar os graus variados de precarização do trabalho também está relacionada ao setor de atividade econômica, visto que alguns setores possuem uma tradição historicamente conquistada, de movimento sindical mais organizado, com maior poder de negociação e mobilização. Como já descrito nos parágrafos acima, os setores mais precários decorrentes do processo de terceirização são também aqueles com movimento sindical com menor capacidade organizativa. Por exemplo, trabalhadores fortemente dispersos geograficamente/por local de trabalho (trabalhadores do setor de vigilância), uma nova e abrupta reorganização produtiva do setor (como no setor de teleatendimento), ou ainda, setores com maior presença de contratos informais ou precários (confecção e calçados).

Por outro lado, os trabalhadores terceirizados que são representados pelo mesmo sindicato dos funcionários da empresa contratante, têm condições e relações de trabalho menos precárias. No entanto, pra driblar essa representação por sindicatos de maior organização, mobilização e representatividade, um recurso frequentemente utilizado pelas empresas é de que a fase do processo que será subcontratada seja classificada como uma atividade distinta da atividade da contratante. Como dito acima, no setor de energia elétrica, os trabalhadores terceirizados são frequentemente representados pelos sindicatos de serviços. Ou ainda no setor financeiro, as empresas que contratam os terceirizados dos bancos são classificadas com atividades econômicas que não estão cobertas pela representação dos sindicatos de trabalhadores bancários.

Por fim, é importante relatar que essa variação é relativa. Mesmo os sindicatos mais fortes do ponto de vista organizacional tem tido dificuldade de enfrentar os dilemas ocasionados pela terceirização, como descritos no item 3.3.4 do presente capítulo. 


\section{Considerações finais}

O exercício de realizar um balanço de teses e dissertações é bastante delicado: organizar e classificar uma grande massa de dados, informações, reflexões e descrições textuais, sendo fiel ao conteúdo elaborado pelos autores dos documentos originais, indicando os pontos de convergência sem ignorar as diferenças estudadas em cada pesquisa de campo. De todo modo, o resultado do balanço da produção acadêmica sobre terceirização através da sistematização das evidências e da construção de indicadores de precarização colaborou para uma visão com abrangência nacional. Consolidamos um painel sobre o processo de terceirização com os temas mais frequentes das condições e relações de trabalho, suas características e os efeitos para trabalhadoras e trabalhadores.

Considerando o material sistematizado no Capítulo 2, pudemos organizar um painel em quatro eixos: Condições de trabalho, Contrato individual de trabalho, Saúde do trabalhador e Ação coletiva e ação sindical. Não foi possível realizar a sistematização do eixo Identidade do trabalhador, conforme relatado acima.

O eixo Saúde do trabalhador foi elaborado a partir dos temas: Ambiente de trabalho, Doenças de trabalho, Acidentes de trabalho, Equipamentos de Proteção Individual e Assédio moral e sexual. De modo geral, as questões relativas à saúde do trabalhador terceirizado são mais precárias do que aquelas oferecidas aos trabalhadores diretamente contratados. Vale destacar que o Brasil tem condições insalubres e perigosas de modo geral, mas os empregadores conseguem piorá-las ainda mais quando se trata de trabalho terceirizado.

Mesmo considerando que de um modo geral, as condições de saúde e segurança no Brasil são negativas há variações quando observamos as trabalhadoras e trabalhadores que são diretamente contratados pelas empresas tomadoras e os terceirizados: os trabalhadores terceirizados que executam suas atividades no interior das empresas contratantes têm ambientes de trabalho relativamente melhores, treinamento e acesso aos EPIs com frequência mais adequada do que aqueles que executam suas atividades 
laborais em locais fora dos muros das empresas tomadoras. Para os trabalhadores terceirizados que executam suas atividades no interior das tomadoras há, porém, diferenças de ambientes de descanso (refeitório, vestuários e banheiros, locais de descanso) em relação aos trabalhadores diretamente contratados, relacionadas à qualidade do ambiente (manutenção e limpeza).

O setor de asseio e conservação é o único que, mesmo realizando suas atividades no interior das empresas contratantes declararam, em diversos casos aqui analisados, não possuir ambientes de descanso adequados e também de não ter acesso a EPIs de qualidade e com a frequência necessária. Esse setor, como se sabe, executa suas atividades no interior de uma empresa tomadora. Dos 12 estudos sobre asseio e conservação, 6 eram de empresas terceiras que prestavam serviços para o setor público, e três empresas terceiras prestavam serviços para o setor privado e o setor público.

Para aqueles que executam suas atividades externamente às tomadoras, há uma variedade de desrespeitos às normas de saúde e segurança, o acesso a EPIs é limitado, em algumas situações não há espaços de descanso tais como prevê as Normas Regulamentadoras da Saúde definidas pelos órgãos públicos do trabalho ${ }^{53}$.

Há também uma terceirização dos riscos à saúde e a vida. Os exemplos mais emblemáticos vieram do setor de energia elétrica e do petroquímico, com ocorrências de acidentes fatais. Em setores como teleatendimento, há um grande índice de adoecimento, mas um número menor de acidentes de trabalho.

Nos setores mais precarizados, como o de confecção e o de calçados, não há medidas protetivas à saúde ou contra acidentes e não há ambientes de trabalho e mobiliário adequados.

No eixo Contrato individual de trabalho, novamente, encontramos graus

\footnotetext{
${ }^{53}$ Até o ano de 2018 quem elaborava as políticas relacionadas ao trabalho, emprego e renda, monitorava as ações e programas e era responsável pela fiscalização do trabalho, era 0 Ministério do Trabalho e Emprego (MTE). A partir de 2019, com a Medida Provisória 871/2019, houve esse Ministério foi extinto, e as secretarias de Políticas públicas de emprego, Relações de trabalho. Inspeção do trabalho e Economia solidária foram distribuídas para outros Ministérios (Justiça, Economia e Mulher, família e direitos humanos).
} 
variados de proteção. A informalidade cresce à medida que a produção se afasta da empresa tomadora, a que é a integradora da produção, ou da empresa que é a ponta da cadeia produtiva: no setor de confecção, as empresas tomadoras exigem a formalização dos contratos de trabalho, no entanto, a quarteirização (terceirização em cascata) oculta as formas mais precárias de contratação, como informalidade, o trabalho a domicílio, trabalho infantil e trabalho análogo ao escravo. Esse processo também foi relatado na rede de fornecimento do setor automotivo.

As trabalhadoras e trabalhadores cooperados na confecção, na prestação de serviços (inclusive de asseio e conservação), em atividades financeiras e na educação privada, em todos os documentos estudados, relataram as condições precárias de salário, jornada de trabalho (ou por longas jornadas ou por insuficiência de horas), direitos trabalhistas e verbas rescisórias. Também registraram as relações antidemocráticas nos locais de trabalho, que colidiam com os princípios do cooperativismo. Em todos os estudos analisados, as cooperativas foram indicadas como forma de driblar 0 contrato de trabalho assalariado por prazo indeterminado, empurrando para os trabalhadores o ônus da atividade produtiva ou de serviços: em caso de queda na produção, redução dos salários.

Em relação às condições de trabalho, os temas mais presentes foram os relativos à remuneração (direta ou indireta), a rotatividade, à jornada de trabalho e a violação de direitos. O conteúdo desses documentos relata, principalmente, as diferenças salariais entre os diretamente contratados pela tomadora e os terceirizados (com salários menores). Há também relatos sobre o frequente atraso no pagamento de salários e mesmo do não pagamento.

Em relação à jornada de trabalho, as empresas utilizam a terceirização como forma de burlar as jornadas regulamentadas para categorias específicas, como bancários, profissionais da saúde e trabalhadores em processo ininterrupto de trabalho.

Outro destaque nos documentos sistematizados, especialmente entre os trabalhadores mais precários dentre os terceirizados (confecção, calçados e asseio e conservação) é a não existência do gozo das férias, seja pela sazonalidade dos contratos de trabalho (confecção e calçados), seja pela troca 
constante de empresa prestadora de serviços (nova empregadora, novo contrato de trabalho). Essa troca constante de contrato de prestação de serviços é um dos fatores que aumenta a rotatividade no trabalho, uma constante na vida das trabalhadoras e dos trabalhadores terceirizados.

Em alguns setores, como calçados e confecção esse movimento é ainda mais intenso: trabalham alguns meses do ano, depois são demitidos (com pagamento de verbas rescisórias ou não), nos períodos de baixa na produção realizam pequenos "bicos" e no próximo ano, retornam para a produção de roupas e calçados. Os que não recebem as verbas rescisórias, dentre aqueles formalizados, não reclamam seus direitos na Justiça do Trabalho, para não ficarem "marcados" e, assim, poderem retornar ao trabalho no próximo ano.

O tempo médio de emprego das trabalhadoras e dos trabalhadores terceirizados, conforme indicado nas teses e dissertações, é sempre reduzido em relação ao dos trabalhadores diretos. Essa característica da precarização, a rotatividade da força de trabalho, é especialmente perversa porque instaura uma constante insegurança na organização da vida dessas trabalhadoras e trabalhadores. Há dois casos que potencializam essa troca de empresas: (1ํ) a empresa vence a licitação e é contratada para um período (dois anos), quando acaba o contrato ela pode ser trocada por outra empresa, os trabalhadores são demitidos e recontratados pela nova empresa; $\left(2^{\circ}\right)$ a empresa vai à falência, antes do término do contrato de serviço acabar, desaparece, e deixa os trabalhadores sem salários e verbas rescisórias.

Em relação ao eixo Ação coletiva e sindical, destacamos os temas da Ação coletiva, a Ação sindical e as Práticas antissindicais. Apesar de não ser possível organizar as informações em indicadores como nos outros eixos, a sistematização das evidências possibilitou destacar as dificuldades que estão presentes na organização dos trabalhadores em decorrência dos processos de terceirização.

A pulverização dos trabalhadores devido à terceirização é um grande desafio para a organização sindical das categorias "tradicionais", mas ainda mais desafiador para as categorias de trabalhadores terceirizados. A fragmentação dos trabalhadores contratados por diferentes empresas e que convivem no mesmo local de trabalho é um dos limitadores, na medida em que 
se dirigem para patrões distintos em suas reivindicações e cria diferenciações concretas e subjetivas entre os trabalhadores. Mais direitos para os trabalhadores terceirizados pode significar a efetividade da aplicação da lei, a não violação de direitos, como no caso dos frequentes atrasos de salários. Para os trabalhadores diretos a pauta de reivindicação se consolida como ampliação de direitos (DIEESE, 2019).

Outra dificuldade para a mobilização é que em algumas categorias os trabalhadores terceirizados estão dispersos geograficamente, como os trabalhadores no setor de vigilância e as trabalhadoras no setor de asseio e conservação. É comum também o rodízio entre diferentes locais de trabalho, restringindo as possibilidades de criação de vínculos com os demais trabalhadores e de laços de solidariedade e identidades coletivas.

As categorias de trabalhadores terceirizados também sofrem com a alta rotatividade, que cria dificuldades para organização a partir de uma relação mais duradoura com as entidades sindicais. No caso de mobilizações como greves e paralisações, além do medo de perder o emprego, soma-se o risco dos descontos nos salários; e isso, para um trabalhador que recebe remunerações ainda mais reduzidas do que a média do mercado de trabalho brasileiro, pode significar maiores restrições no orçamento familiar mensal.

É importante assinalar que a dispersão geográfica e os processos de desverticalização das empresas também foram "resolvidos" pelas entidades sindicais, como é tradicional do sindicalismo brasileiro de Estado (BOITO Jr. 1991), com a estratégia de ampliação do número de sindicatos em detrimento às formas de organização mais agregadas, gerando novos sindicatos de pequeno porte, considerando número de trabalhadores e recursos financeiros e políticos, e com menor capacidade de ação tanto para questões corporativas como para questões de âmbito nacional.

Finalmente, e não menos importante, o arcabouço jurídico nacional limita o direito à organização sindical e à greve, consolidando um quadro bastante desfavorável para atuação sindical e mobilização dos trabalhadores em geral, mas particularmente para as organizações de trabalhadores mais precários no mercado de trabalho. 
Destacar todas as dificuldades adicionais que os segmentos de trabalhadores terceirizados possuem para sua organização enquanto classe, não é considerar que essas barreiras são intransponíveis. Apesar dessas dificuldades, várias das teses e dissertação aqui analisadas (SANCHES, 2006; MARCELINO, 2008; SILVA, 2016; CAVAIGNAC, 2010) apresentaram exemplos de desfechos positivos para as trabalhadoras e os trabalhadores terceirizados, ainda que se tratasse de vitórias pontuais e que não resultasse na reversão da precarização fruto da terceirização, de modo integral.

Segundo Stanging $(2014)^{54}$, a condição do precariado no mercado de trabalho e na sociedade é marcada, pela falta de oportunidades adequadas no mercado de trabalho no que diz respeito ao acesso a emprego e remuneração; de proteção à dispensa arbitrária; de segurança no emprego que lhe permita mobilidade ascendente e segurança no trabalho contra acidentes e doenças; eles sofrem com poucas oportunidades para adquirir novas habilidades; faltaIhes segurança de renda adequada e estável protegida por mecanismos como salário mínimo, recomposição dos salários, previdência social, seguro desemprego; e por fim, esses trabalhadores não têm garantia de representação. Essas características podem assumir formas distintas e com variação na intensidade, devido à heterogeneidade daqueles que compõem esse grupo e das realidades nacionais. Ainda segundo Stanging, além desse conjunto de direitos do trabalho negados ao precariado, é recorrente o acesso também limitado a direitos civis, culturais, sociais, econômico e políticos. Essa limitação dificulta as possibilidades de criação de identidades e ocupacionais, de estabelecimento de ações coletivas, e também reduz a garantia de cidadania, extrapolando as relações de trabalho e se ampliando para todas as esferas das relações sociais.

Vale destacar, como argumenta Marcelino (2011), que o trabalho no Brasil sempre foi marcado pela precariedade, mas esse termo ganha novos significados com as mudanças ocorridas nas condições de trabalho nas últimas

\footnotetext{
${ }^{54}$ Concordamos com as críticas feitas a Stanging, sobre sua avaliação de que o precariado se constitui como uma classe distinta do proletariado. Essa avaliação parte ele parte de uma análise baseada na realidade europeia e ignora que países como o Brasil são marcados por uma precariedade estrutural e histórica nas relações de trabalho (BRAGA, 2014; MARCELINO, 2011). No entanto, as características por ele descritas sobre esse contingente de trabalhadores precarizados são bastante relevantes.
} 
décadas. Precarização se refere às consequências da redução dos direitos trabalhistas, da proteção social e da atuação do Estado nessa regulação para os trabalhadores. A precarização está associada também às consequências para os trabalhadores da inserção de novas tecnologias, da reorganização do espaço das empresas, da necessidade da polivalência e de mecanismos que tornam o salário variável, entre outras (MARCELINO, 2011). A terceirização é uma das maiores expressões dessa precarização no trabalho e na vida.

A nova precariedade que permeia as relações de trabalho a partir da década de 70 e que tem a terceirização como um de suas principais expressões, atinge os trabalhadores que se encontravam em modalidades de empregos estáveis, promove a insegurança das relações de trabalho, fragmenta os coletivos de trabalhadores e amplia a concorrência entre eles. Reflete mudanças nas formas de organização e gestão do trabalho, na legislação trabalhista e social, no papel do Estado e nas políticas sociais. Ela tem aspectos econômicos, sociais e políticos, e renova a precarização estrutural que já existia no Brasil (DRUCK, 2013, P.55-56).

Apesar desse painel bastante amplo e representativo sobre os efeitos e características da terceirização no Brasil, a tese de que a terceirização pode ser apenas uma forma de organizar a produção continua em voga. Essa tese também é reforçada pelo debate acadêmico que apresenta uma concepção dual da terceirização - tem a terceirização que traz ganhos de produtividade e qualidade e tem aquela que precariza.

Essa concepção dual parece ter sido superada nas áreas de conhecimento que tem como foco as relações de trabalho ou as condições sociais dos indivíduos que trabalham em funções subcontratadas. Nas teses e dissertações aqui estudadas, essa dualidade desaparece nos estudos publicados ao longo dos últimos dez anos. As definições de terceirização mais frequentemente utilizados nessas pesquisas são os conceitos propostos por Druck (1995) e Marcelino e Cavalcante (2012), expostos no primeiro capítulo.

Em outras áreas de conhecimento, naquelas que estudam os processos de terceirização sob a óptica dos ganhos empresariais, a definição de terceirização como expressão de relações produtivas modernas, que promovem ganhos de produtividade e qualidade segue justificando as 
vantagens de externalizar produtos e serviços. Esse debate não é sem importância, pois como apresentamos também no capítulo 1, ele colabora para sustentar os argumentos patronais para a defesa da terceirização irrestrita, presentes, por exemplo, na sustentação da Lei 13.429/2017.

Entendemos que o que está em jogo quando se analisa a terceirização do ponto de vista dos trabalhadores ou do ponto de vista das empresas é o que Marx (2001) apontava já no capítulo VIII de O Capital, em 1868: o capitalista compra a capacidade de trabalho e tem o direito de usá-la ao máximo; o trabalhador, aquele que vende sua capacidade de trabalho, tem o direito de protegê-la do que considera uma dilapidação excessiva, ou o comprometimento da possibilidade de vendê-la no futuro para continuar extraindo dela sua sobrevivência. E essa equação se resolveu (ou não) ao longo de toda a história de uma mesma forma: através do embate entre essas duas classes. Seria possível conjugar esses interesses distintos e deixar capitalistas e trabalhadores "satisfeitos"? Na nossa avaliação, apenas e sempre até um determinado ponto, mas como pudemos observar, no presente momento, os interesses de classe dos empregadores tem se consolidado e ampliado remetendo os trabalhadores ao aumento da exploração de sua força de trabalho e a condições de trabalho e de vida cada vez mais precários.

Nas teses e dissertações sistematizadas não houve dúvida: quando analisamos a terceirização na ótica do trabalho, de seus efeitos para os trabalhadores, a precarização em relação aos contratos e às condições de trabalho praticadas pelas empresas tomadoras com seus próprios empregados é uma constante. A variação de formas de como a terceirização impacta cada setor de atividade econômica não deve ser utilizada para reforçar o argumento de dualidade da terceirização: como pudemos comprovar com a atual dissertação, há graus variados de impactos da terceirização, sua implementação tem características distintas a depender do setor analisado, mas em todos os setores o registro foi de precarização das condições e relações de trabalho das trabalhadoras e trabalhadores terceirizados.

\section{- Uma agenda de pesquisa sobre terceirização}


Em nossas considerações finais, também gostaríamos de deixar registrados alguns elementos sobre o campo de conhecimento em que nossa pesquisa está inserida, a Sociologia do Trabalho, e mais especificamente, sobre os estudos relativos à terceirização, sobre a pesquisa de campo nessa temática e sobre possibilidades de temas que podem ser explorados em novas pesquisas.

A Sociologia do Trabalho é uma área disciplinar das Ciências Sociais que sempre teve relevância na produção acadêmica. O debate sobre o fazer ciência em Sociologia do Trabalho, no entanto não é ponto pacifico. Segundo Rodrigues (1967, apud BRAGA; SANTANA, 2009, p. 297) parte importante da maturidade dessa disciplina foi superar "considerações normativas $e$ ideológicas que habitualmente se infiltram nos escritos referentes à classe operaria".

Em outra perspectiva, Abramo (1999) destaca que o caráter militante dessa disciplina não apenas no Brasil, mas em toda a América Latina, seria positivo, pois garantiu que a sociologia do trabalho estivesse sempre relacionada com os temas que marcaram os embates e desafios dos atores sociais e políticos da região. Destaca que essa perspectiva é diferente de um militante no sentido partidário, com uma "identificação totalizando com um determinado ator social' (ABRAMO, 1999, p. 11). Nesse sentido, conclui:

O caráter "militante" da sociologia do trabalho latinoamericana não impediu, no entanto, a sua constituição enquanto uma disciplina científica, institucionalizada academicamente e com uma significativa produção teórica e empírica. Pelo contrário, me atrevo a levantar a hipótese de que esse caráter "militante" foi uma das chaves para que a disciplina tenha sido capaz de desenvolver formulações teóricas próprias e uma experiência de pesquisa sólida e criativa, com um importante grau de autonomia, apesar de haver estado, em cada um dos diferentes períodos acima assinalado, fortemente permeado pelo debate teórico internacional (ABRAMO, 1999, p. 12).

Abramo procura identificar a pergunta central da sociologia do trabalho em cada período, que estaria muito menos associada à evolução da disciplina e muito mais à capacidade de perceber, em cada período histórico, a questão social e política mais relevante para as relações sociais e para a mudança 
social. Nesse sentido, destaca três etapas da sociologia do trabalho na América Latina:

1. A primeira fase tem início no surgimento da disciplina até as décadas de 1950/60: o tema principal era o da modernização, a passagem de uma sociedade agrária e tradicional para uma sociedade urbana e industrial e a emergência de uma classe trabalhadora; com o predomínio de uma sociologia subordinada à economia do desenvolvimento e a uma análise marcada pelo determinismo estruturalista;

2. A segunda etapa vai de meados da década de 1970 até fins da década de 1980: a questão central nessa fase é a polaridade democracia versus ditadura e as possibilidades de reconstrução de uma classe trabalhadora e de um movimento sindical que foram reprimidos durante os regimes militares; há uma recuperação da perspectiva do sujeito e uma relação com a ciência política e a sociologia dos movimentos sociais;

3. O terceiro momento inicia-se no final dos anos 1980, quando o debate central é a crise do taylorismo-fordismo, o surgimento dos "novos modelos de empresa", os processos de ajuste estrutural, de globalização da economia a escala internacional e seus impactos sobre as situações de trabalho. Esse período aprofunda a análise sobre o processo de trabalho e também a relação com a antropologia e a engenharia industrial, e novamente, com a economia. No entanto, esse período acaba tirando novamente o foco dos sujeitos do processo, caminhando quase para um determinismo tecnológico ou econômico (ABRAMO, 199, p. 11).

Leite (2012) também faz uma divisão entre períodos da sociologia do trabalho bastante semelhante ao descrito acima. Reforçando o diagnóstico de que o sujeito desapareceu nos estudos dos anos 1980, elenca:

A teorização esteve marcada por uma nova postura, que se assentava em quatro eixos centrais: (i) um novo desaparecimento do sujeito, oculto agora pela centralidade conferida à empresa, como agente da transformação das relações de trabalho; (ii) uma nova subordinação da sociologia à economia, ignorando as questões sociológicas que as mudanças fundavam e obscurecendo o caráter político das transformações; (iii) um novo determinismo, expresso na ideia da inexorabilidade de uma determinada forma de 
organização do trabalho, erigida como o novo bestoneway; (iv) o privilegiando os estudos de caso na análise das transformações do trabalho (LEITE, 2012, p. 107).

Nosso objeto de estudo foi às teses e dissertações que trataram das condições e relações de trabalho, especificamente, aquelas que traziam dados primários, coletados na pesquisa. As teses e dissertações em sua grande maioria foram estudos de caso. O objetivo era realizar um balanço dessa produção e analisar o impacto para os trabalhadores e suas representações sindicais. No entanto, no percurso da pesquisa diversas questões sobre o fazer pesquisa sociológica nessa área foram surgindo. Gostaríamos de registrá-las, como forma de refletir sobre as dificuldades da pesquisa em sociologia do trabalho e de contribuir para a elaboração (senão de respostas, pelo menos de perguntas!) de metodologias, abordagens e agendas de pesquisa que contribuam para essa disciplina.

\section{- Algumas questões metodológicas}

Uma primeira questão suscitada da leitura das teses e dissertações é a grande dificuldade de conseguir levar a cabo a investigação de campo desenhada no projeto de pesquisa. Os estudos empíricos em sociologia do trabalho, em sua grande maioria, contam apenas com a fala do trabalhador para levantar as informações necessárias para suas análises. Em um país em que as relações de trabalho são fortemente marcadas pelo autoritarismo, entrar em contato com o trabalhador e convencê-lo a falar, ignorando as frequentes ameaças de demissão, é uma dificuldade considerável. Em muitas pesquisas o número de entrevistas realizadas ficou abaixo do esperado, conforme relatado nas pesquisas, em suas notas metodológicas.

$\mathrm{Na}$ maior parte das pesquisas, as pesquisadoras e os pesquisadores não conseguiram visitar o interior das empresas, para conhecer o processo de trabalho, porque os responsáveis pelas empresas negam esse acesso. Em um caso, presente nos documentos analisados, o responsável pela empresa ameaçou a pesquisadora, proibindo-a de se aproximar da empresa e dos 
trabalhadores, em caso de insistência, a empresa chamaria a polícia.

Dessas dificuldades no campo decorrem dois problemas. Primeiro, poucas pesquisas possuem dados mais detalhados sobre como ocorre a organização do processo produtivo, quais as condições ambientais, ritmo de trabalho, etc., para além da fala do trabalhador, essa seria uma coleta de informações importantes para compor uma análise também com o olhar do pesquisador. O segundo problema, e esse talvez seja muito mais grave, as pesquisas com poucas entrevistas tratam de menos temas (aqui chamados de códigos) e muitas vezes o resultado apresentado é enviesado - a perspectiva de dois ou três trabalhadores é pouco representativa. Ou seja, consideramos que parte das pesquisas por nós analisadas podem não ter chegado ao chamado ponto de saturação, onde as entrevistas de natureza qualitativa com novos sujeitos deixam de apresentar elementos novos e passam a repetir informações já obtidas - ponto esse desejável para pesquisas com entrevistas.

O segundo problema derivado da não entrada dos pesquisadores nos locais de trabalho é certa dificuldade nas pesquisas de, analisando as falas das pessoas entrevistadas, separar o que é aparência e o que é essência. Por exemplo: em um dos estudos analisados, uma trabalhadora de uma empresa de asseio e conservação avaliou de forma muito positiva seu posto de trabalho precário. Por que isso aconteceu? As respostas não estão disponíveis, porque, provavelmente, perguntas adicionais não foram feitas. Como leitora, levantei a hipótese de que essa avaliação teria relação com outro dado levantado no perfil da entrevistada: anteriormente, ela trabalhava como empregada doméstica, ocupação ainda mais precária do que aquela em que estava no setor de asseio e conservação; ou seja, considerando seu percurso profissional individual houve uma melhora. Esse tema chamou atenção em mais de uma pesquisa com trabalhadoras do asseio e conservação. Nesse caso, há problemas também relativos à análise do conteúdo das entrevistas, o que confere problemas na elaboração e aplicação de roteiros de entrevistas questionários, e também na apresentação dos resultados.

Houve problemas também em questionários aplicados em pesquisas quantitativas: os questionários não aprofundaram respostas pautadas pelo senso comum, isso ocorreu em questionários com perguntas que avaliavam 
determinadas condições de trabalho com opções de reposta do tipo "ótimo", "bom", "razoável", "ruim", "péssimo". Nesses casos, as repostas tendiam a uma avaliação mediana dos entrevistados, em todos os quesitos e que, posteriormente, não foi problematizado no texto ou em entrevistas qualitativas. Em alguns casos, pode ter ocorrido um viés na forma de aplicação, por exemplo: questionário realizado através de autorresposta, disponibilizado em espaço da empresa, em que pode ter ocorrido confusão de quem era 0 demandante da pesquisa (acadêmica ou a própria empresa?), ou ainda, a preocupação com possíveis perseguições em caso de resposta que declarasse problemas internos nas empresas em questionário por escrito.

Há um grupo importante de pesquisas que não possui nenhuma informação sobre a ação coletiva ou sobre a ação sindical. Esse é um primeiro tema que poderia ser destacado em novas pesquisas. Se for verdade que estamos em um novo contexto produtivo, com impactos que reconfiguram a força de trabalho, qual a repercussão desses fenômenos nas formas de organização coletiva, especificamente, os sindicatos? Em algumas pesquisas há registro sobre a atuação do sindicato preponderante - aquele que representa só trabalhadores da empresa contratante, a principal -, mas não do sindicato que representa a categoria terceirizada. Em muitas pesquisas, apesar de haver o registro da avaliação dos trabalhadores e trabalhadoras sobre o sindicato, os dirigentes sindicais não foram entrevistados para que, diante dessas falas, fosse possível compor um cenário mais robusto sobre a ação sindical.

Outro ponto que podemos citar em relação às questões metodológicas é que as pesquisas mostram uma farta revisão bibliográfica por parte dos autores e autoras dos trabalhos que, normalmente, sistematizam diversos pontos do debate sobre as relações de trabalho no Brasil e no mundo, mas que ficam sem respostas ou análise correspondente na pesquisa de campo. Ou seja, a revisão bibliográfica foi subutilizada ou mal escolhida em seu conjunto de autores e temas escolhidos. Para exemplificar, citamos acima o tema da informalidade: em 42 pesquisas esse tema aparece na revisão bibliográfica, em apenas 12 o tema volta a aparecer na pesquisa de campo; no caso dos contratos dos chamados PJ, encontramos o debate sobre o tema em 15 teses 
e dissertações, mas apenas 5 traziam informações da pesquisa empírica sobre os PJ. Isso aconteceu com ação sindical, práticas antissindicais, saúde do trabalhador, contratos precários, entre outros. Ou seja, falta maior conexão entre a revisão biográfica e os dados investigados no campo, de modo que possamos acumular, enquanto área de pesquisa, conhecimentos em relação a esses temas para, dessa forma, avançarmos em termos de análises, conceitos e temáticas.

É fato que, conforme os objetivos das pesquisas, nem todas as dimensões de trabalho e vida são absolutamente necessárias; mas apresentar algumas indicações sobre essas e outras dimensões apresentadas ao longo desta dissertação, são relevantes para contextualizar o objeto, para entender as atuais relações de trabalho e para que os leitores tenham segurança de que elementos importantes da análise sobre a realidade de trabalhadores terceirizados não tenham sido deixados de lado nas pesquisas.

Outro ponto, mais delicado, mas que não podemos deixar de registrar, diz respeito à qualidade da produção acadêmica na Sociologia do Trabalho. A produção científica não está livre de erros, de equívocos, que sempre poderão ser corrigidos e retificados. Os prazos curtos, os limites de apoio à pesquisa, o volume de trabalho dos orientadores, as lacunas de formação dos pesquisadores e da educação brasileira, permeiam essa produção, inclusive na pesquisa aqui apresentada. Além disso, eventuais problemas pontuais na dissertação dos argumentos podem ocorrer em qualquer produção científica, mesmo com muitas revisões e entre pesquisadores experientes. Mas, para além dessas considerações, acreditamos ser relevante registrar que, em tempos de ataques à produção acadêmica nas ciências humanas, zelar pela qualidade da pesquisa, além de ser obrigação dos pesquisadores envolvidos, é a melhor estratégia para defender esse campo de conhecimento.

Durante a leitura das teses e dissertações selecionadas, encontramos problemas relacionados à qualidade das entrevistas/roteiro de perguntas, que resultaram em respostas com vieses nem sempre explicitados e sob controle do/a pesquisador/a. Também nos deparamos com falta de informações ou informações incompletas. Algumas pesquisas quantitativas incorreram em 
equívocos relacionados ao tamanho da "amostra" 55 e na falta de cuidado com os limites para generalizações. Ainda em relação à pesquisa de campo, encontramos pesquisas em que as informações colhidas no campo não eram suficientes para fundamentar os argumentos descritos. Na falta dos elementos de campo, frequentemente se recorria à literatura, à revisão bibliográfica, para comprovar o argumento, mas faltava uma observação mais efetiva de como, no caso do objeto estudado, aquele determinado tema repercutia. Esses problemas também podem ser resultado de dificuldades para a análise de conteúdo do material coletado no campo.

Também encontramos problemas no uso de conceitos de uso corrente na Sociologia, especialmente, sobre os temas da precarização e terceirização - que em nossa pesquisa, procuramos classificar com mais detalhe -; em alguns casos, havia conflitos entre os conceitos que não foram apontados pelos pesquisadores.

Nosso objetivo com esses apontamentos não é desqualificar o trabalho dos colegas pós-graduandos/as e nem o de seus orientadores/rãs - como se viu ao longo da presente pesquisa, temos uma produção relevante e de qualidade. Antes, queremos destacar a importância política e científica de ampliar a qualidade da produção nessa área da sociologia, de aumentar sua capacidade analítica. Entendemos que esse esforço não precisa, necessariamente, passar por custos - nem sempre suportáveis pelos programas de pós-graduação ou pelos/a próprios/as pesquisadores/as - por exemplo, com revisores profissionais. Mas esse esforço pode passar, por exemplo, pela discussão coletiva dos textos em grupos de pesquisa e orientação.

\section{- Temas para investigação em terceirização - sociologia do trabalho}

Inicialmente, considerando todos os temas que surgiram com a análise bibliométrica das teses e dissertações sobre efeitos da terceirização para as

\footnotetext{
${ }^{55}$ Usamos esse termo entre aspas porque entendemos que definição de amostra é algo necessário apenas em pesquisas de natureza quantitativa.
} 
trabalhadoras e os trabalhadores terceiros, apresentada no capitulo 2, nosso objetivo era analisar cinco eixos (dimensões) que se desdobravam em diversos temas, conforme exposto na tabela 7, na página 78. Como se pôde observar, são temas bastante recorrentes na literatura de sociologia do trabalho e de áreas de conhecimento próximas que também estudam o trabalho e não apenas nos estudos sobre terceirização. Ainda em relação às dimensões da precarização, buscar informações sobre as condições de vida das trabalhadoras e trabalhadores e sobre a organização do processo produtivo também são relevantes.

Sendo assim, uma primeira consideração sobre agenda de pesquisa é sobre a necessidade de ampliar os estudos de síntese sobre temáticas da Sociologia do Trabalho, considerando a grande produção acadêmica e a disponibilidade em meio eletrônico. Esses estudos consolidam as análises já realizadas e podem dar indicações para novos desdobramentos nos temas recorrentes da sociologia do trabalho. Além disso, essas pesquisas dão maior visibilidade à produção científica nesse campo. Nesse sentido, a metodologia aqui adotada, a indicação dos temas que sistematizamos nesta dissertação, ou metodologias semelhantes, podem ser adotas para novos estudos.

Muitos dos códigos investigados não puderam ser sistematizados porque não havia um número de informações suficientes para compor o painel. Mesmo nos campos em que houve possibilidade de sistematização de informações, devido ao número relativamente suficiente de teses e dissertações que apresentaram dados primários sobre o tema, ainda assim, o número poderia ser mais expressivo, por exemplo, no eixo sobre Saúde do trabalhador e Contrato individual de trabalho.

Como sugestão para a agenda de pesquisa, as indicações nos quadros 5, 6, 7, 8 e 9 (páginas 86, 92, 129, 146 e 164) podem auxiliar como base para organizar o trabalho de campo de modo a "cobrir" as dimensões que tem importância para as relações de trabalho. Esses eixos, códigos e evidências foram destacados, no todo ou em parte, por 114 teses e dissertações que tratam da temática da terceirização, mas que também compõe a temática dos estudos em Sociologia do Trabalho. Se a viabilidade de um estudo de caso ampliado, aquele que analisa as determinações recíprocas entre os 
microfenômenos e dos microfenômenos (BURAWOY, 2014), é limitada pela realidade nacional e condições de pesquisa oferecidas para os/as pesquisadores/as brasileiros em nível de pós-graduação, "cobrir" uma grande variedade de temas nas entrevistas com trabalhadores é algo viável e importante. Vale destacar que o registro da não existência de determinado tema, da não existência de determinada forma de precarização do trabalho na pesquisa de campo também é relevante, dá corpo para as análises do campo da Sociologia do Trabalho, pois permite mapearmos as formas mais presentes e menos presentes, e sua relação com o objeto investigado.

Destacamos, a seguir, outros subtemas de pesquisa, que a nosso ver, podem contribuir para esse campo de conhecimento:

Condições de vida do trabalhador: considerando a importância de ampliar a análise para além da empresa, ou procurando superar a centralidade da pesquisa na empresa (LEITE, 2012), vimos que poucos estudos investigaram a vida do trabalhador fora do seu local de trabalho, a maior parte das informações nesse sentido, dizem respeito ao perfil; e elas aparecerem quando são relatadas informações sobre a família. No entanto, além dessa informação, questões relativas ao uso do tempo livre, envolvimento com outros espaços de ação coletiva, as relações sociais no local de moradia, etc., são elementos importantes que compõem as relações sociais as quais os trabalhadores estão inseridos. Um exemplo de observação, nesse sentido, é da pesquisa de Figueiredo (2015), que acompanhou um dia completo da vida de um trabalhador entrevistado, desde o acordar até o retorno para casa.

Classe, gênero e cor/raça: um número considerável de pesquisas sobre terceirização trouxe análises a partir da perspectiva de classe e gênero. Em relação à terceirização, considerando classe e cor/raça encontramos apenas uma pesquisa. Se estudamos as relações sociais, as relações de trabalho, independente do nosso objeto, abordar os temas de raça e gênero podem colaborar com análises mais completas das condições do trabalhador terceirizados; afinal, a precarização do trabalho, quando olhamos para as estatísticas nacionais, tem sexo e cor. Uma das diversas perguntas que ficaram sem resposta foi: se a terceirização é um processo que acomete os trabalhadores mais vulneráveis no mercado de trabalho e se temos setores 
terceirizados que empregam majoritariamente homens, esse lugar de trabalho estaria reservado aos negros?

Identidade e subjetividade no trabalho: mais presente nos estudos da área de psicologia social, esse foi um dos eixos sobre o qual a base de informações sistematizadas não possibilitou apresentar uma análise consistente nos termos previstos através da Revisão Bibliográfica Sistemática e dos códigos previamente definidos que nos interessavam. Aqui poderiam ser abordados de maneira mais sistemática temas como: discriminação; proximidades ideológicas entre trabalhadores ou com partidos, sindicatos, associações; identidade do trabalhador; influências religiosas etc. Em parte das teses e dissertações, fora do campo de psicologia social, os conceitos de identidade e subjetividade foram utilizados de forma "livre", sem uma precisão conceitual. De todo modo, esse campo apareceu de forma tangencial, e poderia ser mais explorado pela Sociologia do Trabalho.

Trajetórias profissionais: algumas teses e dissertações destacaram, ainda que de forma descritiva ou passageira a trajetória profissional dos entrevistados. No entanto, mesmo nessas em que houve essa preocupação, faltou uma relação mais analítica sobre essas trajetórias e as considerações do trabalhador sobre o vínculo empregatício do momento da pesquisa. A pesquisa qualitativa permite fazer uma análise temporal que é mais limita nas pesquisas quantitativas. Destacar esse histórico profissional também acrescenta elementos importantes na análise. Isso ficou evidente em estudos sobre trabalhadores que vieram de outras ocupações mais precárias ainda do que o trabalho terceirizado, ou ainda, em novos polos produtivos e de serviços, que surgiram com a promessa de desenvolvimento da região e novas oportunidades profissionais para trabalhadores locais. 


\section{Referências bibliográficas}

ABRAMO, Laís. Desafios atuais da sociologia do trabalho na América Latina: algumas hipóteses para discussão. In: Los retos teóricos de los estudos del trabajo hacia el siglo XXI. Buenos Aires, AR: Clacso, 1999.

ABREU, A.; SORJ, B. Subcontratação e trabalho a domicílio. In: MARTINS, Heloísa Helena Teixeira de Souza, RAMALHO, José Ricardo. (Org.) Terceirização: diversidade e negociação no mundo do trabalho. São Paulo: Hucitec, CEDI/NETS, 1994.

ALMEIDA, Marina Stefani de. A miríade de atores produtivos na terceirização do calçado em Franca. Dissertação de Mestrado apresentada ao Programa de Pós-Graduação em Sociologia da FFLCH/USP, São Paulo, SP, 2008, $233 \mathrm{p}$.

AMORIM, Elaine Regina Aguiar. No limite da precarização: terceirização e trabalho feminino na indústria de confecção. Tese de doutorado apresentada ao Programa de Pós-Graduação em Sociologia da IFCH/Unicamp, Campinas, SP, 2003, 238p.

ANTUNES, Ricardo. Adeus ao trabalho: ensaio sobre as metamorfoses e a centralidade do mundo do trabalho. 9ª edição. São Paulo: Cortez e Unicamp, 2003.

; DRUCK, Graça. A terceirização como regra? Revista TST, Brasília, DF, v. 79, n.4, p. 214- 231, out/dez, 2013.

AQUINO, Cassio Adriano Braz de; SABÓIA, Iratan Bezerra de; MELO, Pamella Beserra de; CARVALHO, Tainã Alcântara de; XIMENES; Veronica Morais. Terceirização e saúde do trabalhador: uma revisão da literatura nacional. Revista Psicologia: organizações e trabalho, 16(2), abr/jun de 2016, p. 130-142.

BALCÃO, Nilde Ferreira. Terceirização e desmontagem do contrato de trabalho. Dissertação de mestrado apresentada ao Departamento de Sociologia FFLCH/USP, 2000.

BARDIN, Laurence. Análise de conteúdo. São Paulo: Edições 70, 2011, 229 p.

BEAUD, Stéphane e PIALOUX, Michel. Os desafios do método de investigação: o trabalho de campo (Anexo I). In:

Operária. São Paulo: Boitempo, 2009, p. 301-312. 0 retorno à Condição

BLANCO, Manoel Castaño. O processo de terceirização nos bancos. In: Terceirização: diversidade e negociação no mundo do trabalho. São Paulo: Hucitec, CEDI/NETS, 1994.

BRAGA, Ruy. Precariado e sindicalismo no Brasil contemporâneo: um olhar a partir da indústria do call center. Revista Crítica de Ciências Sociais, São Paulo, SP, n. 104, maio, 2014, p. 25-51.

BRAGA, Ruy; SANTANA, Marco Aurélio. O pêndulo oscilante: sociologia do trabalho e movimento sindical no Brasil. Caderno $\mathrm{CRH}$, Salvador, v. 22, n. 56, Maio/Agosto, 2009, p. 297-309.

BRITO, Cicero Muniz. Terceirização, riscos e acidentes Industriais 
ampliados na refinaria Landulpho Alves (RLAM) - Petrobrás (2000 - 2010). Dissertação de mestrado em Ciências Sociais na Universidade Federal da Bahia (UFBA), 2014).

BUROWOY, Michel. O estudo de caso ampliado: raça e classe na África póscolonial. In: Marxismo sociológico. São Paulo, Alameda, 2014, p. 39-96.

CÂMARA DE DEPUTADOS. Mensagem presidencial 389/2002. Disponível em:

$<$ http://www.camara.gov.br/proposicoesWeb/prop mostrarintegra?codteor $=432$

807\&filename $=\mathrm{MSC}+389 / 2003+\% 3 \mathrm{D} \% 3 \mathrm{E}+\mathrm{PL}+4302 / 1998>$. Acesso em: jun./2017.

CÂMARA DOS DEPUTADOS. Lei 13.429/2017. Disponível em: $<$ http://www2.camara.leg.br/legin/fed/lei/2017/lei-13429-31-marco-2017-

784561-norma-pl.html>. Acesso em: ago./2017.

CÂMARA DOS DEPUTADOS. Lei 13.467/2017. Disponível em: <http://www2.camara.leg.br/legin/fed/lei/2017/lei-13467-13-julho-2017-785204norma-pl.html>. Acesso em: ago./2017

CÂMARA DOS DEPUTADOS. Projeto de Lei 1621/2007. Disponível em: $<$ http://www.camara.gov.br/proposicoesWeb/fichadetramitacao?idProposicao=3 59983 >. Acesso em: ago./2017.

CÂMARA DOS DEPUTADOS. Projeto de Lei 4302/1998. Disponível em: $<$ http://www.camara.gov.br/proposicoesWeb/fichadetramitacao?idProposicao=2 0794>. Acesso em: ago./207.

CÂMARA DOS DEPUTADOS. Projeto de Lei 4330/2004. Disponível em: $<$ http://www.camara.gov.br/proposicoesWeb/fichadetramitacao?idProposicao=2 67841>. Acesso em: ago/ 2017.

CAPES. Histórico e evolução do Banto de Teses da CAPES. Disponível em: $<$ http://sdi.Capes.gov.br/banco-de-teses/02_bt_sobre.html>. Acesso em: ago./2017.

CARDOSO, Adalberto. Dimensões da crise do sindicalismo brasileiro. In: SANTANA, Marco Aurélio (Org.). Para onde foram os sindicatos? (dossiê). Caderno CRH, vol. 28, n. 75, Salvador, set/dez. 2015, p. 493-510;

CARELLI, Rodrigo de Lacerda. Terceirização e direitos trabalhistas no Brasil. In: DRUCK, Graça; FRANCO, Tânia (Org.). A perda da razão social do trabalho. SP, São Paulo: Boitempo, 2007.

CARVALHO NETO, Antônio Moura de; CARVALHO, Ricardo Augusto Alves de (Orgs.). Sindicalismo e negociação coletiva nos anos 90. Belo Horizonte: PUC/IRT, 1998.

CARVALHO, Luiz. Bancada do PT fecha acordo contra PL 4330. Notícias CUT, 10/09/2013. Disponível em: <https://www.cut.org.br/noticias/bancada-dopt-fecha-acordo-contra-pl-4330-da-terceirizacao-e-juristas-farao-camp-48d6>.

Acesso em: 20 abr./2018.

CELLARD, André. A análise documental. In: Poupart, Jean. A Pesquisa Qualitativa: enfoques epistemológicos e metodológicos. RJ, Petrópolis: Vozes, 2008, p. 295-316. 
CENTRAIS SINDICAIS. Minuta Projeto de lei: Dispõe sobre os contratos de serviços terceirizados e as relações de trabalho deles decorrentes celebrados por pessoas de natureza jurídica de direito privado. São Paulo, SP: Centrais Sindicais, 2009, (Mimeo).

CHIARA, Marcia de. Terceirização não tira direitos, diz ministro do Trabalho. Estadão, Puntadel Leste, Uruguai, 01/04/2017. Disponível em: $<$ https://economia.estadao.com.br/noticias/geral,terceirizacao-e-um-fenomenoglobal-diz-ministro-do-trabalho,70001722930>. Acesso em: jan./2018.

CNC. CNC Notícias. Revista da Confederação Nacional do Comércio de Bens, Serviços e Turismo, n. 197, abril 2017, ano XVII. Disponível em: <http://cnc.org.br/sites/default/files/arquivos/cnc_197.pdf>. Acesso em: abr./2018a.

CNC. Regulamentação da terceirização traz avanços para as relações trabalhistas, 24/03/0217. Disponível em: <http://cnc.org.br/noticias/relacoesde-trabalho/regulamentacao-da-terceirizacao-traz-avancos-para-relacoestrabalhista>. Acesso em: abr./2018b.

CNI. Agenda legislativa anual da indústria: pauta mínima, edição de bolso. Disponível em: < Disponível em: <http://www.portaldaindustria.com.br/publicacoes/2015/12/agenda-legislativada-industria/\#agenda-legislativa-da-industria-2018\%20>. Acesso em: mai./2018b.

CNI. Mapa estratégico 2013-2022: propostas para a eleição 2014 Terceirização, 0 imperativo das mudanças. Disponível em: <http://www.portaldaindustria.com.br/relacoesdotrabalho/media/publicacao/cha madas/V8_Terceirizacaooimperativodasmudancas_web_1.pdf >. Acesso em: abr./2018a.

CONFORTO, Edivandro C.; AMARAL. Daniel C.; SILVA, Sérgio Luis. Roteiro para revisão bibliográfica sistemática: aplicação no desenvolvimento de produtos e gerenciamentos de projetos. 8 $^{\circ}$ congresso Brasileiro de Gestão de Desenvolvimento de Produto, 2011, 12 p.

CORDEIRO, Rosemary de Matos. As aglomerações produtivas de calçados, folheados e de joias do Crajubar (CE): formação, produção, trabalho, implicações socioespaciais. Tese de Doutorado apresentada ao Programa de Pós-Graduação em Geografia da UNESP, Rio Claro, SP, 2015, 328 p.

COSTA, Paula Cesariano. A precisão no despenhadeiro. Folha de São Paulo, São Paulo, 10/09/2017. Disponível em: <http://www1.folha.uol.com.br/colunas/paula-cesarino-costaombudsman/2017/09/1917102-a-precisao-nodespenhadeiro.shtml?loggedpaywall>. Acesso em: abr./2018.

COSTA, Rodolfo. Terceirização não elimina direitos trabalhistas, dizem especialistas. O Correio Brasiliense, Brasília, DF, 25/03/2017. Disponível em: $<$ https://www.correiobraziliense.com.br/app/noticia/economia/2017/03/25/intern as economia,583504/terceirizacao-nao-elimina-direitos-trabalhistas-dizemespecialistas.shtml>. Acesso em: jan./2018.

CRISTINA, Iva. PL 4.330/2004: CCJ adia votação da terceirização para agosto. 
DIAP Notícias, 11/08/2013. Disponível em: http://www.diap.org.br/index.php/noticias/noticias/22589-pl-4330-2004-cci-adiavotacao-da-terceirizacao-para-agosto . Acesso em: 20 abr./2018.

CUNHA, Yuri Rodrigues da.Terceirização e terceirizados: um estudo sobre os impactos objetivos e subjetivos da terceirização sobre trabalhadores terceirizados que atuam no setor de limpeza em escolas estaduais no município de Marília-SP. Dissertação de Mestrado apresentada ao Programa de Pós-Graduação em Ciências Sociais da UNESP, Marília, SP, 2015, 147 p.

DAU, D. M.: RODRIGUES, I. J. \& CONCEIÇÃO, J.J. (Orgs.). Terceirização no Brasil: do discurso da inovação à precarização do trabalho. São Paulo: Anablume/CUT, 2009.

DELGADO, Maria Berenice Godinho. Terceirização e trabalho feminino. In: Terceirização: diversidade e negociação no mundo do trabalho. São Paulo: Hucitec, CEDI/NETS, 1994.

DIAP. Terceirização: o que está em debate no Judiciário, no Executivo e no Parlamento. DIAP Notícias, 27/07/2016. Disponível em: $<$ http://www.diap.org.br/index.php/noticias/em-debate/26201-terceirizacao-o-ueesta-em-debate-no-judiciario-no-executivo-e-no-parlamento>. Acesso em: 14 ago./2016.

DIAP. Centrais lançam nota sobre terceirização: regular sem precarizar. DIAP Notícias, 15/08/2013. Disponível em: $<$ http://www.diap.org.br/index.php/noticias/noticias/22827-centrais-lancam-notasobre-terceirizacao-regular-sem-precarizar>. Acesso em: abr.2018.

DIAP. Terceirização: PL de FHC é prioridade de votação na Câmara, 2008. Disponível em: <http://www.diap.org.br/index.php/component/content/article?id=1093-manobraregimental-terceirizacao-pl-de-fhc-e-prioridade-de-votacao-na-camara>. Acesso em: abr./2018.

DIAS, Sabrina de Oliveira Moura. Dentro da usina, mas fora da "família": trabalhadores e terceirização na CSN. Dissertação de mestrado apresentado ao programa de pós-graduação em Sociologia e Antropologia, Universidade Federal do Rio de Janeiro, Rio de Janeiro, RJ, 01/02/2010, 150 páginas.

DIEESE. A Reforma Trabalhista e os impactos para as relações de trabalho no Brasil. Nota técnica, n. 178, maio de 2017, São Paulo, 2010, 22p.

Balanço das greves de 2018. Estudos \& Pesquisas, n. 89, abril de 2019, São Paulo, 55p.

Terceirização e morte no trabalho: um olhar sobre o setor elétrico no Brasil. Estudos \& Pesquisas, n. 50, março de 2010. São Paulo, 18p.

DIEESE/CUT. Acompanhamento das negociações coletivas pós reforma trabalhista: relatório dos impactos no primeiro semestre de 2018. Disponível em: http://cedoc.cut.org.br/cedoc/livros-e-folhetos/6392. Acesso em: jan./2019.

. Terceirização e desenvolvimento: uma conta que não fecha. São Paulo: DIEESE/CUT, 2011.

DIEESE/SEADE. Sistema PED: metodologia. São Paulo. Disponível em: 
$<$ file://C:/Users/adriana/Desktop/metodologia\%20de20pesquisa/metodologiaPe d.pdf>. Acesso em: 01 jul./2016.

Terceirização: (des)fordizando a fábrica. In: ; FRANCO, Tânia

(Org.) A perda da razão social do trabalho. São Paulo: Boitempo, 2007.

DRUCK, Graça. A precarização social do trabalho no Brasil. In Riqueza e miséria do trabalho no Brasil II, ANTUNES, Ricardo (org.). São Paulo, SP: Boitempo, 2013.

DRUCK, Maria da Graça. Terceirização: a erosão dos direitos dos trabalhadores na França e no Brasil. Tese de doutorado apresentada ao Programa de Pós-Graduação em Sociologia do IFCH/UNICAMP, Campinas, SP, 1999, 275p.

DRUCK, Maria da Graça. Trabalho, precarização e resistências: novos e velhos desafios. Caderno CHR, Salvador, v.24, n. spe01, 2011, p.37-57.

DRUCK, Maria da Graça; BORGES, Ângela. Terceirização: balanço de uma década. Caderno CHR, Salvador, n. 37, p. 111-139, jul./dez. 2002.

FARIA, Aparecido. Terceirização: um desafio para o movimento sindical. In: Terceirização: diversidade e negociação no mundo do trabalho. São Paulo: Hucitec, CEDI/NETS, 1994.

FERREIRA, Norma Sandra de Almeida. As pesquisas denominadas "Estado da arte". Educação \& Sociedade, ano XXIII, n. 79, p. 257-272, agosto, 2002.

FLEURY, Afonso; VARGAS, Nilton (Orgs.). Organização do trabalho: uma abordagem interdisciplinar. São Paulo: Atlas, 1983.

FLEURY, Maria T L.; FISCHER, Rosa Maria (Orgs.). Processos e relações de trabalho no Brasil. São Paulo: Atlas, 1985.

FUNARO, Vânia Martins Bueno de Oliveira; NORONHA, Daisy Pires. Literatura cinzenta: canais de distribuição e incidência nas bases de dados. In: POBLACION, Dinah Aguiar; WITTER, Geraldina Porto; SILVA, José Fernando Modesto (orgs.). Comunicação e produção científica. São Paulo: Angellara, 2006.

GARCIA, Leila Posenato. Revisão sistemática da literatura e integridade na pesquisa. Epidemiol. Serv. Saúde, Brasília, 23(1):7-8, jan-mar 2014.

GARCIA, Sandro Ruduit. Subcontratação. In: CATANNI, Antonio David; HOLZMANN, Lorena (orgs.). Dicionário de trabalho e tecnologia. Porto Alegre: Zouk, 2011.

GOMES, Isabelle Sena; CAMINHA, Iraquitan de Oliveira. Guia para estudos de revisão sistemática: uma opção metodológica para as ciências do movimento humano. Revista Movimento, Porto Alegre, v. 20, n. 01, p. 395-411, jan/mar de 2014.

GOMEZ, Carlos Minayo Gomez; VASCONCELOS, Luiz Carlos Fadel de; MACHADO, Jorge Mesquita Huet. Saúde do trabalhador: aspectos históricos, avanços e desafios. Ciência \& Saúde Coletiva, 23(6): 1963-1970, 2018, p. 1963-1970.

GOMES, Maria Terezinha Serafim. 0 debate sobre a reestruturação 
produtiva no Brasil. Revista Raega, n. 21, p. 51-77, UFPR, Curitiba, PR, 2011.

HARVEY, David. Condição pós-moderna: uma pesquisa sobre as origens da mudança cultural. São Paulo: Loyola, 5 edição. 1992.

HIRATA, Helena. Os mundos do trabalho: convergência e diversidade num contexto de mudança de paradigmas produtivos. In: Empregabilidade e educação: novos caminhos no mundo do trabalho. São Paulo: PUC/Rhodia, 1997.

HOFFMANN, Marise P.; BRANDÃO, Sandra M.C. Mediação de emprego: Recomendações da OIT e práticas nacionais. Campinas, nov. 1996. Caderno Cesit, 22.

RODRIGUES, Iram Jacome. Trabalhadores e sindicalismo no Brasil: para onde foram os sindicatos? In: SANTANA, Marco Aurélio (Org.). Para onde foram os sindicatos? (dossiê). Caderno $\mathrm{CRH}$, vol. 28, n. 75, Salvador, set/dez. 2015, p. 479-567.

JANUZZI, Paulo de Martino. Indicadores Sociais no Brasil: conceitos, fontes de dados e aplicações. Campinas, SP: Alínea, 2006.

JORGE, Heber Rebouças. Terceirizar, flexibilizar, precarizar: um estudo crítico sobre a terceirização do trabalho. Dissertação de mestrado em Sociologia. Instituto de Filosofia e Ciências Humanas - Universidade Estadual de Campinas, SP, 2011.

SILVA JUNIOR, Luiz Alberto; LEÃO, Marcelo Brito Carneiro. O software Atlas.ti como recurso para a análise de conteúdo: analisando a robótica no ensino de ciências em teses brasileiras. Ciênc. Educ., Bauru, v. 24, n. 3, p. 715-728, 2018.

KREIN, Dari; CASTRO, Barbara. As formas flexíveis de contratação e a divisão sexual do trabalho. In: LEONE, Eugenia Troncoso; KREIN, José Dari; TEIXEIRA, TEIXEIRA, Marilane Oliveira. Mundo do trabalho das mulheres: ampliar direitos e promover a igualdade. Campinas, SP: UNICAMP/IE/CESIT, 2017.

KREIN, José Dari. O desmonte dos direitos, as novas configurações do trabalho e o esvaziamento da ação coletiva, Tempo Social, revista de sociologia da USP, v. 30, n.1, pp. 77-104.Disponível em: http://www.scielo.br/pdf/ts/v30n1/1809-4554-ts-30-01-0077.pd . Acesso em mai./2019.

Tendências recentes nas relações de emprego no Brasil: 19902005. Tese de doutorado. Campinas, SP: Unicamp, 2007.

LEIRIA, Jerônimo Souto. Terceirização: uma alternativa de flexibilidade empresarial. Porto Alegre: Sagra; DC Luzzato, 1992.

LEITE, Márcia de Paula (Org.). O trabalho em movimento: reestruturação produtiva e sindicatos no Brasil. Campinas, SP: Papirus, 1997.

A sociologia do trabalho na América Latina: seus temas e problemas (re)visitados. Sociologia \& Antropologia, v.02.04, 2012, p.103-127. 
LIMA, Angela Maria de Sousa. As faces da subcontratação do trabalho: um estudo com trabalhadoras e trabalhadores da confecção de roupas de Cianorte e região. Tese de doutorado apresentada ao Programa de Pós-Graduação em Ciências Sociais do IFCH/Unicamp, Campinas, SP, 2009, 355 p.

LOPES, Maria Immacolata Vassalo; ROMANCINI, Richard. Teses e dissertações: estudo bibliométrico na área de comunicação. In: POBLACION, Dinah Aguiar; WITTER, Geraldina Porto; SILVA, José Fernando Modesto (orgs.). Comunicação e produção científica. São Paulo: Angellara, 2006.

LOUREIRO, Ubirajara. Informalidade e terceirização: os problemas maiores. Jornal do Brasil, Rio de Janeiro, RJ, 13/06/2009. Disponível em: http://www.jb.com.br/economia/noticias/2009/06/13/informalidade-eterceirizacao-os-problemas-maiores/ . Acesso em: abr./2018.

MAQUINE, Roberto Mateus. Responsabilidade subsidiária da Administração Pública pelos créditos trabalhistas na hipótese de inadimplemento do prestador de serviços terceirizados. Monografia apresenta na Faculdade de Direito/USP, 2012.

MARCELINO, Paula R. P. A logística da precarização: terceirização do trabalho na Honda do Brasil. Dissertação de mestrado. Unicamp, Campinas, SP, 2002.

Terceirização e ação sindical: a singularidade da reestruturação do capital no Brasil. Tese de doutorado em Ciências Sociais. IFCH - Unicamp, Campinas, SP, 2008. 373 p.

.; CAVALCANTE, S. Por uma definição de terceirização. Caderno $\mathrm{CRH}$, Salvador, v. 25, n. 65, p. 331-346, maio/agosto, 2012.

As palavras e as coisas: uma nota sobre a terminologia dos estudos contemporâneos de trabalho. In: Dossiê: classes sociais e transformações no mundo do trabalho, Mediações, Londrina, v. 16, n.1, p. 55-70, jan./jun. 2011.

Sindicalismo e neodesenvolvimentismo: analisando as greves entre 2003 e 2013 no Brasil. Tempo Social, revista de sociologia da USP, v. 29, n.3, 2017, p. 201-277.

MARCELINO, Paula; CAVALCANTE, Sávio. Por uma definição de terceirização. In: Caderno $\mathrm{CRH}$, Salvador, v. 25, n. 65, p. 331-346, maio/agosto, 2012.

MARTINS, Heloísa de Souza. Os dilemas do movimento sindical em face da terceirização. In: Terceirização: diversidade e negociação no mundo do trabalho. São Paulo: Hucitec, CEDI/NETS, 1994.

MEC. Portaria no 013, de 15 de fevereiro de 2006. $<$ http://www.Capes.gov.br/images/stories/download/legislacao/Portaria 01320 06.pdf>. Acesso em: agosto/2017.

MIRANDA, Tiago. Projeto da terceirização não entra em pauta: votação deve ser em agosto. Câmara notícias, 10/07/2013. Disponível em: <http://www2.camara.leg.br/camaranoticias/noticias/trabalho-e-

previdencia/447298-projeto-da-terceirizacao-nao-entra-em-pauta-votacao-deveser-em-agosto.html>. Acesso em: 20 abr./2018. 
Ministério do Trabalho e Emprego. RAIS: Registro Anual de Informações Sociais. Disponível em: <http://www.rais.gov.br/sitio/index.jsf>. Acesso em: 01/07/2016.

Oorganização Internacional doTrabalho/PREALC. Sistemas de información para el análisis del mercado de trabajo. Santiago, CHI: OIT/Prealc, n. 277, jun. 1986.

OLMO, F. Terceirização no setor bancário. Disponível em: $<$ https://jus.com.br/artigos/48928/terceirizacao-no-setor-bancario >. Acesso em: 05 ago. 2016.

PACKER, A. L.; MENEGHINI, R. Visibilidade da produção científica. In: POBLACION, D. A.; WITTER, G. P.; SILVA, J. F. M. da. Comunicação \& produção científica: contexto, indicadores e avaliação. São Paulo: Angellara, 2006. p. 237-259.

PAIM, Paulo. Parecer da Comissão Especial do Desenvolvimento Nacional: PLS 30/2015, PLS 87/2010, PLS 447/2011, PLS 300/2015, PLS 339/2016. Gabinete do Senador Paulo Paim. DF, Brasília: 2016 (Mimeo).

PAIVA, Aice Rangel; SORJ, Bila. Subcontratação e trabalho a domicílio: a influência do gênero. In: Terceirização: diversidade e negociação no mundo do trabalho. São Paulo: Hucitec, CEDI/NETS, 1994.

PAULINO, A. Y.; MARCOLINO, A. A Busca de novos espaços de negociações sindicais frente à reestruturação produtiva: o caso da Mercedes-Benz/SBC. In: DIEESE. Emprego e desenvolvimento tecnológico: sistemas de relações de trabalho e negociações coletivas. São Paulo: DIEESE/CESIT/CNPq, 1999. Projeto de Pesquisa e Formação Técnica DIEES/CESIT/CNPq, Linha 2.

PETROLI, Flávio Matos. Breve análise sobre o contrato individual de trabalho, 2017. Acessado em out./2018. Disponível em: $<$ https://flavioff.jusbrasil.com.br/artigos/398518689/breve-analise-sobre-ocontrato-individual-de-trabalho $>$.

PINTO, Ana Estela de Souza. Terceirização não derruba salários. Folha de São Paulo, São Paulo, 03/09/2017. Disponível em: <http://www1.folha.uol.com.br/mercado/2017/09/1915215-terceirizacao-naoderruba-os-salarios-mostra-estudo.shtml 03/09/2017> Acesso em: abr./2018.

IBGE/PNAD Contínua. Pesquisa Nacional por Amostra de Domicílio Contínua - questionário treinamento. Disponível em: $<$ http://www.ibge.gov.br/home/estatistica/indicadores/sipd/Questionario PNAD Continua.pdf>. Acesso em: 15 jul./2016.

IBGE/PNAD. Pesquisa Nacional por Amostra de Domicílio: 2014. Disponível em:

$<\mathrm{ftp}: / /$ ttp.ibge.gov.br/Trabalho e Rendimento/Pesquisa Nacional por Amostra de Domicilios anual/2014/q pnad2014.pdf>. Acesso em: 15 jul./2016.

PRESIDÊNCIA DA REPÚBLICA. Consolidação das Leis do Trabalho, Decreto Lei 5452/1943. Disponível em: $<$ http://www.planalto.gov.br/ccivil 03/decreto-lei/Del5452.htm>. Acesso em: jun./2017. 
. Consolidação das Leis do Trabalho. Decreto Lei 5.452/1943.

Disponível em: <http://www.planalto.gov.br/ccivil 03/decretolei/Del5452compilado.htm>. Acesso em: dez./2017.

Decreto-Lei 200/1967. Disponível em:

<http://www.planalto.gov.br/ccivil 03/decreto-lei/Del0200.htm>. Acessado em: abri./2018 .

Lei 10.406/2010.Disponível em:

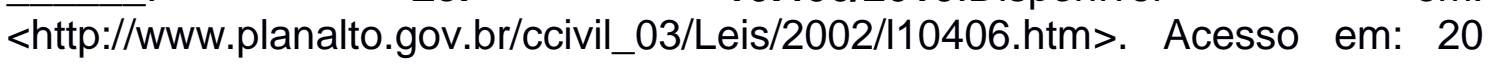
jan./2018.

Lei 6.019/1974. Disponível em: <http://www.planalto.gov.br/ccivil 03/Leis/L6019.htm>. Acesso em: jun./2017.

Lei 7.102/1983. Disponível em: <http://www.planalto.gov.br/CCivil 03/leis/L7102.htm>. Acesso em: jun./2017.

RAMALHO, J. R.; RODRIGUES, I. J. Trabalho, flexibilidade e terceirização: o caso da indústria automotiva. In: DAU, D.M; RODRIGUES, I.J.; CONCEIÇÃO, J.J. (Orgs.). Terceirização no Brasil: do discurso da inovação à precarização do trabalho. São Paulo: Annablume, 2009.

RAMOS, Dora Maria de Oliveira. Terceirização na Administração Pública. São Paulo: LTr, 2001.

RODRIGUES, Leôncio Martins. Destino do Sindicalismo. São Paulo: Edusp, 1999.

SALERNO, Mario S. Produção, trabalho e participação: CCQ e kanban numa nova imigração japonesa. In: FLEURY, Maria T L.; FISCHER, Rosa Maria (Orgs.). Processos e relações de trabalho no Brasil. São Paulo: Atlas, 1985.

SAMPAIO, R. F; MANCINI M C. Estudos de revisão sistemática: um guia para síntese criteriosa da evidência científica. Revista Brasileira de Fisioterapia, São Carlos, v. 11, n. 1, p. 83-90, jan/fev de 2017.

SANTANA, Marco Aurélio (Org.). Para onde foram os sindicatos? (dossiê). Caderno CRH, vol. 28, n. 75, Salvador, set/dez. 2015, p. 453-567.

SENADO FEDERAL. Projeto de Lei do Senado 30/2015. Disponível em: <https://www25.senado.leg.br/web/atividade/materias/-/materia/119695>.

Acesso em: ago./2017.

Projeto de Lei do Senado 300/2015. Disponível em: <https://www25.senado.leg.br/web/atividade/materias/-/materia/121328>. Acesso em: ago./2017.

Projeto de Lei do Senado 447/2011. Disponível em: <https://www25.senado.leg.br/web/atividade/materias/-/materia/101383>. Acesso em: ago./2017.

Projeto de Lei do Senado 554/2015. Disponível em: <https://www25.senado.leg.br/web/atividade/materias/-/materia/122826>. Acesso em: ago./2017.

Projeto de Lei do Senado 87/2010. Disponível em: <https://www12.senado.leg.br/ecidadania/visualizacaomateria?id=96305>. 
Acesso em: ago./2017.

SILVA, F.C. Terceirização e trabalho informal: o caso da indústria de confecção. In: DAU, D.M; RODRIGUES, I.J.; CONCEIÇÃO, J.J. (Orgs.). Terceirização no Brasil: do discurso da inovação à precarização do trabalho. São Paulo: Annablume, 2009.

SILVA, José Fernando Modesto da Silva; RAMOS, Lucia Maria S. V. Costa; NORONHA, Daisy Pires. Base de dados. In: POBLACION, Dinah Aguiar; WITTER, Geraldina Porto; SILVA, José Fernando Modesto (orgs.). Comunicação e produção científica. São Paulo: Angellara, 2006.

SILVA, Poliana de Sousa. O processo de terceirização do trabalho dos carroceiros da zona norte de Teresina - PI. Dissertação de mestrado apresentada ao Programa de Pós-Graduação em Sociologia da Fundação Universidade Federal Do Piauí, Teresina, 2014, 105 p.

SMABC/DIEESE. Os trabalhadores e a terceirização: diagnóstico e propostas dos metalúrgicos do ABC. São Bernardo do Campo, SP: Editora FG, 1993

SOUTO MAIOR, J. L. Trabalho descentralizado: terceirização não pode ser usada para burlar direitos. Disponível em: <http://www.conjur.com.br/2004jul06/terceirizacao nao usada burlar direitos> Acesso em: 06 jul./2016.

A história do Direito do Trabalho no Brasil. Curso de Direito do Trabalho, vol. I - parte II. São Paulo: LTr, 2017.

. Impeachment, corrupção, hipocrisia e terceirização. Blog ed. Boitempo, mar./2015. Disponível em: https://blogdaboitempo.com.br/2015/03/13/impeachment-corrupcao-hipocrisiae-terceirizacao/ . Acessado em mai./2019.

SOUZA, Leonardo; MALDONADO, Maurício; RADOS, Gregório. Gestão da terceirização no setor brasileiro de distribuição de energia elétrica. Revista de Administração de Empresas, vol.51, no. 2, p. 188-201. São Paulo, mar./abr., 2011.

STANDING, Guy. O precariado e a luta de classes. Revista Crítica de Ciências Sociais, 103, maio 2014, p. 9-24.

SUPREMO TRIBUNAL FEDERAL (STF). STF decide que é lícita a terceirização em todas as atividades empresariais. Disponível em: http://www.stf.jus.br/portal/cms/verNoticiaDetalhe.asp?idConteudo=388429 . Acessado em dez./2018.

TAYLOR, Frederick W. Princípios de administração científica. São Paulo: Atlas, 1980.

Tribunal Superior do Trabalho (TST). Súmula 256/1983. Disponível em: $<$ http://www3.tst.jus.br/jurisprudencia/Sumulas com indice/Sumulas Ind 251 300.htm|\#SUM-256>. Acesso em: jun./2017.

Súmula 331/1993. Disponível em: $<$ http://www3.tst.jus.br/jurisprudencia/Sumulas com indice/Sumulas Ind 301 350.htm|\#SUM-331>. Acesso em: jun./2017.

UNIVERSIDADE ESTADUAL Paulista (UNESP). Tipos de revisão de 
literatura. Biblioteca Prof. Paulo de Carvalho Matos, Botucatu, 2015, 9 p. Diponível em: < https://www.fca.unesp.br/Home/Biblioteca/tipos-de-evisao-deliteratura.pdf $>$.

UNIVERSIDADE DE SÃO PAULO (USP). Diretrizes para apresentação de dissertações e teses da USP, $3^{\text {a }}$ edição, 2016. Disponível em: file:///C:/Users/adriana/Downloads/document.pdf. Acessado em: 20 mar./2018.

VALENÇA, Myrian; BARBOSA, Allan. A Terceirização e seus Impactos: um estudo em grandes organizações de Minas Gerais. Revista de Administração Contemporânea, vol.6, n.1, Curitiba, jan./abr./2002.

WATERMAN, Peter. The new social unionism: a new union model for a new world order. In: MUNCK, Ronaldo and WATERMAN, Peter (Ed). Labour worldwide in the era of globalisation: alternative union models in the new world order. London: Macmillan Press, 1999.

ZYLBERSTAJN, E. Três ensaios sobre o mercado de trabalho no Brasil. Tese de doutorado em Economia. Escola de Economia, Fundação Getúlio Vargas. São Paulo, 2015.

\subsection{Referências bibliográficas - Teses e dissertações utilização na Revisão Bibliográfica Sistemática}

ALMEIDA, Marina Stefani de. A miríade de atores produtivos na terceirização do calçado em Franca. Mestrado apresentado ao programa de pós-graduação em Sociologia, Universidade de São Paulo, São Paulo, SP, 01/09/2008, 230 páginas.

AMORIM, Eliane Regina Aguiar. No limite da precarização? Terceirização e trabalho feminino na indústria de confecção. Mestrado apresentado ao programa de pós-graduação em Sociologia, Universidade Estadual de Campinas, Campinas, SP, 01/12/2003, 180 páginas.

ANDRETA, Rachel Loureiro. 0 trabalho terceirizado no Brasil: uma representação da precarização? Da caracterização geral à especificidade do setor de limpeza em Santa Maria/RS no contexto dos anos 2000. Mestrado apresentado ao programa de pós-graduação em Ciências Sociais. Universidade Federal de Santa Maria, Santa Maria, RS, 30/03/2016, 213 páginas.

BARBARINI, Neuzi. Trabalho bancário e reestruturação produtiva: implicações no psiquismo dos trabalhadores. Mestrado apresentado ao programa de pós-graduação em Psicologia Social e Institucional. Universidade Federal do Rio Grande do Sul, Porto Alegre, RS, 01/04/2001, 168 páginas.

BARBOSA, Atilla Magno e Silva. Mudanças organizacionais e diferenciação social: os trabalhadores da indústria do alumínio primário paraense. Doutorado apresentado ao programa de pós graduação em Sociologia. Universidade Federal de São Carlos, São Carlos, SP, 01/08/2010, 152 páginas. 
BARBOSA, Jarbas de Almeida. A hierarquia da precarização: a terceirização em cascata no complexo automotivo baiano. Mestrado apresentado ao programa de pós-graduação em Ciências Sociais. Universidade Federal da Bahia, Salvador, BA, 07/10/2013, 258 páginas.

BARROS, Regina Célia de. Terceirização de serviços dos trabalhadores de escolas públicas do Distrito Federal - processos de intensificação e precarização do trabalho. Mestrado apresentado ao programa de pósgraduação em Educação. Universidade de Brasília, Brasília, DF, 30/03/2016, 109 páginas.

BARROS, Sergio Paes de. Biopolítica, neoliberalismo e vulnerabilidade: os trabalhadores terceirizados na universidade pública. Tese de doutorado apresentada ao programa de pós graduação em Psicologia Social. Universidade de São Paulo, São Paulo, SP, 08/06/2015, 157 páginas.

BICEV, Jonas Tomazi. Os trabalhadores subcontratados da região metropolitana de São Paulo: precariedade ou estabilização?. Mestrado apresentado ao programa de pós-graduação em Sociologia. Universidade de São Paulo, São Paulo, SP, 01/10/2010, 74 páginas.

BRITO, Cicero Muniz. Terceirização, riscos e acidentes industriais ampliados na refinaria Landulpho Alves (RLAM) - Petrobrás (2000 - 2010). Mestrado apresentado ao programa de pós-graduação em Ciências Sociais. Universidade Federal da Bahia, Salvador, BA, 19/03/2014, 253 páginas.

BRITO, José Eustáquio de. Reestruturação da Telemar e a constituição de competência industriosa na operação de serviços aos usuários: uma investigação a partir da abordagem ergológica. Doutorado apresentado ao programa de pós graduação em Educação. Universidade Federal de Minas Gerais, Belo Horizonte, MG, 01/09/2008, 321 páginas.

CAETANO, Edson. Da qualificação à terceirização: os caminhos da competitividade. Doutorado apresentado ao programa de pós graduação em Educação. Universidade Estadual de Campinas, Campinas, SP, 01/03/2001, 193 páginas.

CALEFFI, Vilma Marta. Reestruturação produtiva na indústria do vestuário e as implicações para a qualificação dos trabalhadores. Mestrado apresentado ao programa de pós-graduação em Educação. Universidade Federal de Santa Catarina, Florianópolis, SC, 01/12/2008, 148 páginas.

CAMPOS, Ginez Leopoldo Rodrigues de. Trabalho precário, terceirização e cooperativas de trabalho: quando "estar juntos" se torna uma forma coletiva e precária de inclusão social. Doutorado apresentado ao programa de pós graduação em Sociologia e Política. Universidade Federal de Santa Catarina, Florianópolis, SC, 01/09/2009, 210 páginas.

CARVALHO, Josué Pires de. A terceirização no trabalho bancário: implicações materiais e simbólicas. Mestrado apresentado ao programa de pós-graduação em Sociologia. Universidade Federal de Goiás, Goiânia , GO, 01/11/2006, 113 páginas.

CASTRO, Maurício Valente Souto de. A criatividade e resistência social em São José dos Campos/SP: alternativas operárias aos impactos da 
reestruturação produtiva da General Motors na década de 1990. Mestrado apresentado ao programa de pós-graduação em Sociologia Política. Universidade Federal de Santa Catarina, Florianópolis, SC, 01/05/2005, 127 páginas.

CAVAIGNAC, Mônica Duarte. Relações de trabalho e relações no trabalho na lógica capitalista contemporânea: um olhar sobre atendentes do call center de uma empresa de telecomunicações. Doutorado apresentado ao programa de pós graduação em Sociologia. Universidade Federal do Ceará, Fortaleza, CE, 01/09/2010, 250 páginas.

CHAGAS, Herika Christina Amador. Trabalhadoras e suas jornadas: reflexões sobre a terceirização em um órgão público federal. Mestrado apresentado ao programa de pós-graduação em Antropologia. Universidade de Brasília, Brasília, DF, 06/03/2014, 111 páginas.

COSTA, Samuel Nogueira. Reestruturação produtiva da economia e terceirização (ou semi-escravidão?): os sentidos do trabalho e as disputas por representação sindical dos trabalhadores terceirizados da universidade de Brasília na era do capitalismo manipulatório. Mestrado apresentado ao programa de pós-graduação em Sociologia. Universidade de Brasília, Brasília, DF, 27/06/2016, 172 páginas.

CRICO, Ana Paula. As relações de trabalho na indústria calçadista de Franca. Mestrado apresentado ao programa de pós-graduação em História. Universidade Federal de Uberlândia, Uberlândia, MG, 01/08/2006, 110 páginas.

CUNHA, Yuri Rodrigues da. Terceirização e terceirizados: um estudo sobre os impactos objetivos e subjetivos da terceirização sobre trabalhadores terceirizados que atuam no setor de limpeza em escolas estaduais no município de Marília-SP. Mestrado apresentado ao programa de pósgraduação em Ciências Sociais. Universidade Estadual Paulista Júlio de Mesquita Filho, Marília, SP, 26/01/2015, 147 páginas.

DIAS, Ana Patrícia. A face perversa da terceirização: a reprodução das desigualdades e dos conflitos entre os trabalhadores. Doutorado apresentado ao programa de pós-graduação em Sociologia. Universidade Federal da Paraíba/João Pessoa, João Pessoa, PB, 01/03/2011, 210 páginas.

DIAS, Gracialino da Silva. Educação e relações de trabalho no cenário da globalização: o jogo da terceirização. Mestrado apresentado ao programa de pós-graduação em Educação. Universidade Federal do Paraná, Curitiba, PR, 01/05/1998, 119 páginas.

DIAS, Sabrina de Oliveira Moura. Dentro da usina, mas fora da "família": trabalhadores e terceirização na CSN. Mestrado apresentado ao programa de pós-graduação em Sociologia e Antropologia. Universidade Federal do Rio de Janeiro, RJ, 01/02/2010, 150 páginas.

DUQUE, Priscila Rodrigues. As implicações remuneratórias e subjetivas das novas formas de contrato: um estudo sobre a contratação fundacional no hospital universitário João de Barros Barreto (HUJBB). Mestrado apresentado ao programa de pós-graduação em Sociologia e Antropologia. Universidade Federal do Pará, Belém, PA, 27/09/2013, 86 páginas. 
GOULARTI, Alcides. A inserção da indústria do vestuário na economia do sul de Santa Catarina. Mestrado apresentado ao programa de pós-graduação em Geografia. Universidade Federal de Santa Catarina, Florianópolis, SC, 01/09/1995, 186 páginas.

FARIA, Maria da Graça Druck de. Terceirização: (des) fordizando a fábrica um estudo do complexo petroquímico da Bahia. Doutorado apresentado ao programa de pós graduação em Ciências Sociais. Universidade Estadual de Campinas, Campinas, SP, 01/09/1995, 270 páginas.

FIGUEIREDO, Igor Silva. A terceirização em alta voltagem na Cemig: crônica da degradação do trabalho. Mestrado apresentado ao programa de pós-graduação em Sociologia. Universidade Estadual de Campinas, Campinas, SP, 02/07/2015, 127 páginas.

FREITAS, Maslowa Islanowa Cavalcanti. O movimento metamórfico do capital e reestruturação produtiva: o caso do centro industrial de Subaé. Doutorado apresentado ao programa de pós graduação em Ciências Sociais. Universidade Federal da Bahia, Salvador, BA, 01/02/2006, 201 páginas.

JÚNIOR, Jaime Santos. Fragmentos do trabalho: identidade operária no trabalho terceirizado. Mestrado apresentado ao programa de pós-graduação em Ciências Sociais. Fundação Universidade Federal de Sergipe, São Cristóvão, SE, 01/09/2007, 110 páginas.

LIMA, Angela Maria de Sousa. As faces da subcontratação do trabalho: um estudo com trabalhadoras e trabalhadores da confecção de roupas de Cianorte e região. Doutorado apresentado ao programa de pós-graduação em Ciências Sociais. Universidade Estadual de Campinas, Campinas, SP, 01/06/2009, 274 páginas.

LIMA, Luis Carlos de Araújo. O compromisso ético político do psicólogo terceirizado na política pública de saúde no município de São Paulo. Doutorado apresentado ao programa de pós graduação em Psicologia (Psicologia social). Pontifícia Universidade Católica de São Paulo, São Paulo, SP, 28/10/2016, 169 páginas.

MALERBA, Paulo Eduardo Silva. As transformações do setor financeiro no Brasil: os trabalhadores e a fragmentação da representação sindical. Mestrado apresentado ao programa de pós-graduação em Ciência Política. Universidade Estadual de Campinas, Campinas, SP, 01/03/2011, 180 páginas.

MARCELINO, Paula Regina Pereira. A logística da precarização: terceirização do trabalho na Honda do Brasil. Mestrado apresentado ao programa de pós-graduação em Sociologia. Universidade Estadual de Campinas, Campinas , SP, 01/08/2002, 240 páginas.

Terceirização e ação sindical: a singularidade da reestruturação do capital no Brasil. Doutorado apresentado ao programa de pós graduação em Ciências Sociais. Universidade Estadual de Campinas, Campinas, SP, 01/03/2008, 320 páginas.

MARTINS, Márcio. A psicodinâmica do reconhecimento no trabalho de informática de terceirizados e concursados de uma instituição pública. Mestrado apresentado ao programa de pós-graduação em Psicologia Social, 
do Trabalho e das Organizações (PSTO). Universidade de Brasília, Brasília, DF, 01/12/2012, 130 páginas.

MATOS, Alfredo Assunção. Satisfeito ou satisfazendo? Estudo sobre a satisfação dos trabalhadores terceirizados: quando trabalhar precariamente não é uma questão de escolha. Mestrado apresentado ao programa de pósgraduação em Psicologia. Universidade Federal do Rio de Janeiro, Rio de Janeiro, RJ, 29/02/2016, 164 páginas.

MAYER, Jair Alberto. Relações precárias em cooperativas de trabalho: estudo de caso em Pelotas - RS. Mestrado apresentado ao programa de pósgraduação em Ciências Sociais. Universidade Federal de Pelotas, Pelotas, RS, 01/10/2009, 142 páginas.

MENDES, Josiane. A terceirização na área de atendimento telefônico em Curitiba: um estudo sobre o sistema flexível de acumulação. Mestrado apresentado ao programa de pós-graduação em Sociologia. Universidade Federal do Paraná, Curitiba, PR, 01/04/2005, 109 páginas.

OLIVEIRA, Andre Luis Amorim de. Aspectos da dinâmica socioterritorial do trabalho terceirizado: em busca dos "territórios terceirizados". Mestrado apresentado ao programa de pós-graduação em Geografia. Fundação Universidade Federal de Mato Grosso do Sul, Três Lagoas, MG, 21/03/2014, 288 páginas.

OLIVEIRA, Ricardo Gonçalves de. Terceirização e ação sindical no trabalho bancário: dilemas entre o discurso e a prática. Doutorado apresentado ao programa de pós graduação em Sociologia e Antropologia. Universidade Federal do Rio de Janeiro, Rio de Janeiro, RJ, 26/08/2014, 246 páginas.

OLIVEIRA, Sérgio Macedo. Cooperativas de trabalho de professores do ensino superior privado, na cidade de São Paulo. Uma forma de precarização do trabalho docente (1994-2005). Mestrado apresentado ao programa de pós-graduação em Educação. Universidade Nove de Julho, São Paulo, SP, 01/12/2008, 150 páginas.

PEDREIRA, Liliane Santos. Sindiquímica, a luta continua companheiro? Uma análise das práticas sindicais na era do neoliberalismo (1989-2002). Mestrado apresentado ao programa de pós-graduação em História. Universidade Estadual de Feira de Santana, Feira de Santana, BA, 17/08/2015, 139 páginas.

PEREIRA, Lawrence da Silva. As transformações no mundo do trabalho frente ao processo de flexibilização. Mestrado apresentado ao programa de pós-graduação em Sociologia política. Universidade Federal de Santa Catarina, Florianópolis, SC, 01/09/2009, 118 páginas.

PEREIRA, Maria Erica Ribeiro. As engrenagens da terceirização na assistência social: estudo com trabalhadores do centro de referência especializado da assistência social (CREAS). Mestrado apresentado ao programa de pós-graduação em Sociologia. Universidade Estadual do Ceará, Fortaleza, CE, 26/03/2015, 188 páginas.

PINZON, Heidy Johanna Garrido. Vivências de trabalhadores da saúde frente à lógica capitalista: um estudo da atenção básica na Colômbia e no 
Brasil. Ddoutorado apresentado ao programa de pós-graduação em Psicologia. Pontifícia Universidade Católica de Campinas, Campinas, SP, 29/02/2016, 198 páginas.

PIRES, Denise Elvira. Processo de trabalho em saúde no Brasil, no contexto das transformações na esfera do trabalho - estudo em instituições escolhidas. Doutorado apresentado ao programa de pós-graduação em Ciências Sociais. Universidade Estadual de Campinas, Campinas, SP, 01/12/1996, 320 páginas.

REIS, Cinthia Regina Nunes. Cooperativismo e cooperativas de trabalho: 0 caso de grupos de trabalhadores em confecções de Lima Campos - Maranhão. Mestrado apresentado ao programa de pós-graduação em Sociologia. Universidade Federal de Pernambuco, Recife, PE, 01/08/2003, 141 páginas.

RIOS, Mino Correia. Atribuições iguais, vínculos organizacionais desiguais: investigando os contratos psicológicos de terceirizados e não-terceirizados. Mestrado apresentado ao programa de pós-graduação em Psicologia Universidade Federal da Bahia, Salvador, BA, 01/08/2007, 155 páginas.

ROSSETTI, Eliane Guerreiro. Flexibilização da produção: a terceirização na indústria de Limeira, SP. Mestrado apresentado ao programa de pósgraduação em Geografia (organização do espaço). Universidade Estadual Paulista Júlio de Mesquita Filho, São Paulo, SP, 01/11/1996, 141 páginas.

SANCHES, Ana Tércia. Terceirização e terceirizados no setor bancário: relações de emprego, condições de trabalho e ação sindical. Mestrado apresentado ao programa de pós-graduação em Ciências Sociais. Pontifícia Universidade Católica de São Paulo, São Paulo, SP, 01/12/2006, 159 páginas.

SANTOS, Adna Oirideia Rabelo dos. 0 trabalho do atendente de call center. adoecimento por LER/DORT e descartabilidade". Mestrado apresentado ao programa de pós-graduação em Psicologia. Universidade Federal do Ceará, Fortaleza, CE, 01/05/2006, 107 páginas.

SANTOS, Cesar Alexandre dos. A "comodificação" de uma empresa pública: o caso da companhia paranaense de energia - Copel. Mestrado apresentado ao programa de pós-graduação em Ciências Sociais. Universidade Estadual de Londrina, Londrina, PR, 01/12/2009, 185 páginas.

SANTOS, Gustavo Carvalho dos. Tempos modernos: a terceirização na Universidade Federal do Recôncavo da Bahia. Mestrado profissional apresentado ao programa de pós-graduação em Gestão de Políticas Públicas e Segurança Social. Universidade Federal do Recôncavo da Bahia, Cruz das Almas, BA, 30/01/2014, 119 páginas.

SCAVICHIA, Gloriete Santos. Terceirização e trabalhadores da construção civil na cidade de Araraquara/SP. Mestrado apresentado ao programa de pós-graduação em Ciências Sociais. Universidade Estadual Paulista Júlio de Mesquita Filho/Araraquara, Araraquara, SP, 02/06/2015, 140 páginas.

SILVA, Claudia Socoowski de Anello E. A invisibilidade social na terceirização: um estudo da experiência do pólo naval de Rio Grande. Mestrado apresentado ao programa de pós-graduação em Sociologia. Universidade Federal de Pelotas, Pelotas, RS, 06/05/2016, 184 páginas. 
SILVA, Georgina Alves Vieira da. Organizações flexíveis: identidade elásticas? A reconstrução da identidade social em processos de terceirização. Doutorado apresentado ao programa de pós graduação em Psicologia Social. Universidade de São Paulo, São Paulo, SP, 01/09/2002, 230 páginas.

SILVA, José Ailton Gondim da. Terceirização no serviço público: estudo de caso na fundação universidade estadual do Ceará - FUNECE. Mestrado profissional apresentado ao programa de pós-graduação em Planejamento e Políticas Públicas. Universidade Estadual do Ceará, Fortaleza, CE, 01/11/2006, 161 páginas.

SILVA, Poliana de Sousa. O processo de terceirização do trabalho dos carroceiros da zona norte de Teresina - PI. Mestrado apresentado ao programa de pós-graduação em Sociologia. Fundação Universidade Federal do Piauí, Teresina, PI, 25/09/2014, 105 páginas.

SILVA, Ricardo Margonari da. Terceirização e precarização: o caso da universidade federal de Uberlândia no período 2000-2014. Mestrado apresentado ao programa de pós-graduação em Ciências Sociais. Universidade Federal de Uberlândia, Uberlândia, MG, 30/09/2015, 170 páginas.

SOBRINHO, Zéu Palmeira. Reestruturação produtiva e terceirização - o caso dos trabalhadores das empresas contratadas pela Petrobrás no RN. Doutorado apresentado ao programa de pós-graduação em Ciências Sociais. Universidade Federal do Rio Grande do Norte, Natal, RN, 01/12/2006, 259 páginas.

SOUZA, Gladys Lissie Arouca de. Terceirização em enfermagem: uma reestruturação hospitalar?. Mestrado apresentado ao programa de pósgraduação em Educação. Universidade Estadual de Campinas, Campinas, SP, 01/12/2000, 147 páginas.

SOUZA, Maria Terezinha Gonçalves de. A exploração do trabalho infantil no setor coureiro-calçadista na região do Vale do Rio dos Sinos-São Leopoldo. Mestrado apresentado ao programa de pós-graduação em Geografia. Universidade Federal do Rio Grande do Sul, Porto Alegre, RS, 01/01/2005, 413 páginas.

TEIXEIRA, Tadeu Gomes. Os correios em transformação: reestruturação, organização do trabalho e políticas de gestão do trabalho (1994 - 2011). Doutorado apresentado ao programa de pós-graduação em Ciências Sociais. Universidade Estadual de Campinas, Campinas, SP, 26/11/2013, 303 páginas.

VENTURIN, Suzane. A reestruturação econômica e social da indústria têxtil no Vale do Rio Itapocu-SC, pós-1980. Mestrado apresentado ao programa de pós-graduação em Geografia. Universidade Federal de Santa Catarina, Florianópolis, SC, 27/04/2016, 227 páginas.

VIEIRA, Patrícia Santiago. 0 trabalho em saúde nos hospitais de gestão terceirizada: o caso do estado de Goiás. Mestrado apresentado ao programa de pós-graduação em Sociologia. Universidade Federal de Goiás, Goiânia, GO, 05/07/2013, 226 páginas.

VILASBOAS, Jaqueline Pereira de Oliveira. A capital goiana do jeans: flexibilidade, subcontratação e gênero no setor de confecção do município de 
Jaraguá-GO. Doutorado apresentado ao programa de pós-graduação em Ciências Sociais. Universidade Estadual de Campinas, Campinas, SP, 18/03/2015, 295 páginas. 


\section{Anexos}

\section{ANEXO I - Documentos que não foram encontrados para a classificação do balanço da produção acadêmica brasileira sobre condições e relações de trabalho dos terceirizados - Análise Bibliométrica}

Pesquisa realizada em: BDTD, CAPES/Sucupira, repositórios institucionais, Comut, buscadores internet, Ligação telefônica para a biblioteca de origem e/ou envio de email.

\begin{tabular}{|c|c|c|c|c|c|c|c|c|}
\hline № & NOME & $\mathrm{H} / \mathrm{M}$ & TÍTULO & $\begin{array}{l}\text { UNIVERSIDAD } \\
\mathbf{E}\end{array}$ & CIDADE & UF & BIBLIOTECA & $\begin{array}{l}\text { Docdisponivel para } \\
\text { análise }\end{array}$ \\
\hline 28 & $\begin{array}{l}\text { Organista, Jose } \\
\text { Henrique Carvalho }\end{array}$ & $\mathrm{H}$ & $\begin{array}{l}\text { O processo de informalização das } \\
\text { relações de trabalho: estado, } \\
\text { desregulamentação e } \\
\text { informalização (2007) }\end{array}$ & $\begin{array}{l}\text { Universidade } \\
\text { Do Estado Do } \\
\text { Rio De Janeiro }\end{array}$ & $\begin{array}{l}\text { Rio de } \\
\text { Janeiro }\end{array}$ & $\mathrm{RJ}$ & PPCIS & $\begin{array}{l}\text { A biblioteca informou } \\
\text { que não dispõe de } \\
\text { nenhum serviço para } \\
\text { esse fim. }\end{array}$ \\
\hline 70 & $\begin{array}{l}\text { Borges, Ricardo } \\
\text { Luís Espínola }\end{array}$ & $\mathrm{H}$ & $\begin{array}{l}\text { Nas teias da flexibilização a } \\
\text { terceirização por intermédio de } \\
\text { cooperativas de trabalho na região } \\
\text { do Vale do Trairi/RN (2005) }\end{array}$ & $\begin{array}{l}\text { Universidade } \\
\text { Federal Do Rio } \\
\text { Grande Do } \\
\text { Norte }\end{array}$ & Natal & $\mathrm{RN}$ & $\begin{array}{c}\text { Biblioteca Central Zila } \\
\text { Mamede }\end{array}$ & $\begin{array}{l}\text { Não obtive retorno da } \\
\text { biblioteca após contato } \\
\text { telefônico. }\end{array}$ \\
\hline 81 & $\begin{array}{l}\text { Ceolin, Edir } \\
\text { Teresinha }\end{array}$ & $\mathrm{H}$ & $\begin{array}{l}\text { A terceirização do ensino de } \\
\text { informática é também um } \\
\text { excludente na educação básica? } \\
(2001)\end{array}$ & $\begin{array}{l}\text { Universidade } \\
\text { Do Vale Do Rio } \\
\text { Dos Sinos }\end{array}$ & $\begin{array}{c}\text { São } \\
\text { Leopoldo }\end{array}$ & $\mathrm{RS}$ & Biblioteca da UNISINOS & $\begin{array}{l}\text { Não tem na biblioteca; } \\
\text { enviado email para } \\
\text { autora, sem resposta. }\end{array}$ \\
\hline 114 & $\begin{array}{l}\text { Maia, Maria } \\
\text { Zenilda Gonçalves } \\
\text { Barbosa }\end{array}$ & $\mathrm{M}$ & $\begin{array}{l}\text { Um retrato em preto e branco: } \\
\text { mulheres trabalhadoras em } \\
\text { tempos de terceirização } \\
\text { precarizada (2005) }\end{array}$ & $\begin{array}{l}\text { Universidade } \\
\text { Federal Do } \\
\text { Ceará }\end{array}$ & Fortaleza & CE & Biblioteca de Humanidades & $\begin{array}{l}\text { não foi encontrado na } \\
\text { biblioteca a copia } \\
\text { física, nem o registro. }\end{array}$ \\
\hline 118 & $\begin{array}{l}\text { Martins, Omari } \\
\text { Ludovico }\end{array}$ & $\mathrm{H}$ & $\begin{array}{l}\text { A organização dos servidores da } \\
\text { universidade federal de Goiás } \\
(2001)\end{array}$ & $\begin{array}{l}\text { Universidade } \\
\text { Federal De } \\
\text { Goiás }\end{array}$ & Goiânia & $\mathrm{GO}$ & UFG & $\begin{array}{l}\text { Não obtive retorno da } \\
\text { biblioteca após contato } \\
\text { telefônico. Ficaram de } \\
\text { responder via email. }\end{array}$ \\
\hline 130 & $\begin{array}{l}\text { Parreiras, Oraida } \\
\text { Maria Urbanetto } \\
\text { De Souza }\end{array}$ & ND & $\begin{array}{l}\text { Colocados no trecho: } \\
\text { trabalhadores itinerantes na } \\
\text { indústria brasileira de papel e } \\
\text { celulose (2007) }\end{array}$ & $\begin{array}{l}\text { Universidade } \\
\text { Federal } \\
\text { Fluminense }\end{array}$ & Niterói & RJ & $\mathrm{BIG}$ & $\begin{array}{l}\text { Não foi possível entrar } \\
\text { em contato a partir dos } \\
\text { telefones informados e } \\
\text { nem após solicitação } \\
\text { via email. }\end{array}$ \\
\hline 139 & Perpétuo, Glória & $\mathrm{M}$ & Ação coletiva e democracia em & Universidade & Belo & MG & Biblioteca da Faculdade de & Não obtive retorno da \\
\hline
\end{tabular}




\begin{tabular}{|c|c|c|c|c|c|c|c|c|}
\hline & Regina Olíva & & $\begin{array}{l}\text { busca de elementos para a } \\
\text { compreensão da presença política } \\
\text { de atores coletivos (2001) }\end{array}$ & $\begin{array}{l}\text { Federal De } \\
\text { Minas Gerais }\end{array}$ & Horizonte & & $\begin{array}{c}\text { Filosofia e Ciências } \\
\text { Humanas }\end{array}$ & $\begin{array}{l}\text { biblioteca após contato } \\
\text { telefônico e envio de } \\
\text { email. }\end{array}$ \\
\hline 147 & $\begin{array}{l}\text { Salgado, Gilberto } \\
\text { Barbosa }\end{array}$ & $\mathrm{H}$ & $\begin{array}{l}\text { O imaginário em movimento } \\
\text { crescimento e expansão da } \\
\text { indústria editorial no Brasil (1995) }\end{array}$ & $\begin{array}{c}\text { Instituto } \\
\text { Universitário De } \\
\text { Pesquisa Do } \\
\text { Rio De Janeiro }\end{array}$ & $\begin{array}{l}\text { Rio de } \\
\text { Janeiro }\end{array}$ & $\mathrm{RJ}$ & - & $\begin{array}{l}\text { Documento não está } \\
\text { disponível. }\end{array}$ \\
\hline 151 & $\begin{array}{l}\text { Santana, } \\
\text { Francisco José } \\
\text { Duarte De }\end{array}$ & $\mathrm{H}$ & $\begin{array}{l}\text { As consequências da } \\
\text { informatização de setores } \\
\text { estratégicos de uma empresa } \\
\text { estatal na capacitação de sua mão } \\
\text { de obra (1996) }\end{array}$ & $\begin{array}{l}\text { Universidade } \\
\text { Federal Da } \\
\text { Bahia }\end{array}$ & Salvador & $\mathrm{BA}$ & $\begin{array}{l}\text { Anísio Teixeira - } \\
\text { FACED/UFBA }\end{array}$ & $\begin{array}{l}\text { Não obtive retorno da } \\
\text { biblioteca após envio } \\
\text { de email. }\end{array}$ \\
\hline 159 & $\begin{array}{l}\text { Schorner, } \\
\text { Ancelmo }\end{array}$ & $\mathrm{H}$ & $\begin{array}{l}\text { A arco-íris encoberto Jaraguá do } \\
\text { Sul, o trabalho e a história: } \\
\text { operários, colonos-operários e } \\
\text { facções (1997) }\end{array}$ & $\begin{array}{l}\text { Universidade } \\
\text { Federal De } \\
\text { Minas Gerais }\end{array}$ & $\begin{array}{c}\text { Belo } \\
\text { Horizonte }\end{array}$ & $M G$ & $\begin{array}{c}\text { Faculdade de Filosofia e } \\
\text { Ciências Humanas da } \\
\text { UFMG }\end{array}$ & $\begin{array}{l}\text { Não obtive retorno da } \\
\text { biblioteca após contato } \\
\text { telefônico e envio de } \\
\text { email. }\end{array}$ \\
\hline
\end{tabular}




\section{ANEXO II - Sistematização das Teses e dissertações sobre Terceirização disponíveis na Capes/Grande Área de Conhecimento Ciências Humanas}

(Primeiros 05 registros do Banco de Dados, análise Bibliométrica, apenas para ilustração)

Legenda cores:

\begin{tabular}{|l|l|}
\hline Grupo 1 & $\begin{array}{l}\text { Terceirização e trata das relações e condições de } \\
\text { trabalho }\end{array}$ \\
\hline Grupo 2 & $\begin{array}{l}\text { Terceirização, mas não trata das relações e condições } \\
\text { de trabalho }\end{array}$ \\
\hline Grupo 3 & Fora do escopo \\
\hline & Não encontrado \\
\hline
\end{tabular}

\begin{tabular}{|c|c|c|c|c|c|c|c|c|c|c|c|c|c|}
\hline \multicolumn{14}{|c|}{ Continua... } \\
\hline № & $\begin{array}{c}\text { GRUP } \\
0\end{array}$ & NOME & H/M & TítULO & $\begin{array}{l}\text { DADA DE } \\
\text { DEFESA }\end{array}$ & $\begin{array}{l}\text { № } \\
\text { DE } \\
\text { PAG. }\end{array}$ & $\begin{array}{l}\text { TITULAÇ } \\
\text { ÃO }\end{array}$ & AREA & UNIVERSIDADE & CIDADE & UF & BIBLIOTECA & $\begin{array}{l}\text { Resumo } \\
\text { SALVO }\end{array}$ \\
\hline 1 & 2 & $\begin{array}{l}\text { Almeida, } \\
\text { Marina } \\
\text { Castro De }\end{array}$ & $M$ & $\begin{array}{l}\text { Em outro ponto da rede: } \\
\text { desenvolvimento geográfico desigual e } \\
\text { o "vaivém" do capital nas operações } \\
\text { de contactcenter }\end{array}$ & $03 / 12 / 2013$ & 206 & Doutorado & $\begin{array}{l}\text { Geografia } \\
\text { (Geografia } \\
\text { humana) }\end{array}$ & $\begin{array}{l}\text { Universidade De } \\
\text { São Paulo }\end{array}$ & São Paulo & SP & CAPH-FFLCH-USP & Completo \\
\hline 2 & 1 & $\begin{array}{l}\text { Barbosa, } \\
\text { Atilla Magno } \\
\text { e Silva }\end{array}$ & 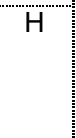 & $\begin{array}{l}\text { Mudanças organizacionais e } \\
\text { diferenciação social: os trabalhadores } \\
\text { da indústria do alumínio primário } \\
\text { paraense }\end{array}$ & $01 / 08 / 2010$ & 152 & Doutorado & Sociologia & $\begin{array}{l}\text { Universidade } \\
\text { Federal De São } \\
\text { Carlos }\end{array}$ & São Carlos & $\mathrm{SP}$ & $\begin{array}{l}\text { Biblioteca Comunitária da } \\
\text { UFSCar }\end{array}$ & Completo \\
\hline 3 & 1 & $\begin{array}{l}\text { Barros, } \\
\text { Sergio Paes } \\
\text { De }\end{array}$ & $\mathrm{H}$ & $\begin{array}{l}\text { Biopolítica, neoliberalismo e } \\
\text { vulnerabilidade: os trabalhadores } \\
\text { terceirizados na universidade pública }\end{array}$ & $08 / 06 / 2015$ & 157 & Doutorado & $\begin{array}{l}\text { Psicologia } \\
\text { Social }\end{array}$ & $\begin{array}{l}\text { Universidade De } \\
\text { São Paulo }\end{array}$ & São Paulo & SP & $\begin{array}{l}\text { Biblioteca Dante Moreira } \\
\text { Leite do Instituto de } \\
\text { Psicologia da } \\
\text { Universidade de São } \\
\text { Paulo }\end{array}$ & Completo \\
\hline 4 & 1 & $\begin{array}{l}\text { Brito, José } \\
\text { Eustáquio De }\end{array}$ & 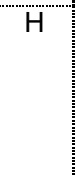 & $\begin{array}{l}\text { Reestruturação da Telemar e a } \\
\text { constituição de competência } \\
\text { industriosa na operação de serviços } \\
\text { aos usuários: uma investigação a } \\
\text { partir da abordagem ergológica }\end{array}$ & $01 / 09 / 2008$ & 321 & Doutorado & Educação & $\begin{array}{c}\text { Universidade } \\
\text { Federal De Minas } \\
\text { Gerais }\end{array}$ & $\begin{array}{l}\text { Belo } \\
\text { Horizonte }\end{array}$ & $\begin{array}{l}M \\
G\end{array}$ & Faculdade de Educação & Completo \\
\hline 5 & 1 & $\begin{array}{l}\text { Caetano, } \\
\text { Edson }\end{array}$ & $\mathrm{H}$ & $\begin{array}{l}\text { Da qualificação à terceirização: os } \\
\text { caminhos da competitividade }\end{array}$ & $01 / 03 / 2001$ & 193 & Doutorado & Educação & $\begin{array}{l}\text { Universidade } \\
\text { Estadual De } \\
\text { Campinas }\end{array}$ & Campinas & SP & Biblioteca Central & Completo \\
\hline
\end{tabular}


NSA - Não se aplica (por exemplo, quando se trata de serviços).ND - Não disponível (revisar na análise do texto completo). *Numeração colunas.

Continuação....

\begin{tabular}{|c|c|c|c|c|c|c|c|c|c|c|c|c|}
\hline № & $\begin{array}{c}\text { GRUP } \\
0\end{array}$ & $\begin{array}{l}\text { Doc } \\
\text { disponív } \\
\text { el para } \\
\text { análise }\end{array}$ & $\begin{array}{c}\text { OBJETO } \\
\text { INVESTIGADO }\end{array}$ & $\begin{array}{l}\text { OBJETIVO } \\
\text { INVESTIGADO }\end{array}$ & $\begin{array}{c}\text { TIPO DE } \\
\text { PESQUIS } \\
\text { A }\end{array}$ & $\begin{array}{c}\text { TEORIAS/AUTO } \\
\text { RES }\end{array}$ & $\begin{array}{l}\text { SETORES DE } \\
\text { ATIVIDADE } \\
\text { ECONOMICA } 1\end{array}$ & $\begin{array}{l}\text { SETORES DE } \\
\text { ATIVIDADE } \\
\text { ECONOMICA } 2\end{array}$ & EMPRESA & $\begin{array}{l}\text { CIDADE BASE } \\
\text { DA PESQUISA }\end{array}$ & $\begin{array}{c}\text { UF } \\
\text { BASE } \\
\text { DA } \\
\text { PESQUI } \\
\text { SA }\end{array}$ & INDICADORES \\
\hline 1 & 2 & Capes & Território & $\begin{array}{l}\text { Analisar a apropriação do } \\
\text { desenvolvimento } \\
\text { geográfico desigual } \\
\text { brasileiro através da } \\
\text { difusão de empresas de } \\
\text { teleatendimento; divisão } \\
\text { territorial do trabalho. }\end{array}$ & Empírica & & PRIVADO & $\begin{array}{c}\text { Serviços de } \\
\text { teleatendimento }\end{array}$ & $\begin{array}{l}\text { Contact } \\
\text { Center }\end{array}$ & $\begin{array}{c}\text { Nordeste } \\
\text { (Centros } \\
\text { urbanos não } \\
\text { metropolitanos) }\end{array}$ & $\mathrm{NE}$ & NSA \\
\hline 2 & 1 & Tese & $\begin{array}{c}\text { Trabalhadores } \\
\text { diretos e } \\
\text { terceirizados }\end{array}$ & $\begin{array}{l}\text { Estudar a diferenciação } \\
\text { social entre trabalhadores } \\
\text { diretos e indiretos em } \\
\text { uma empresa de } \\
\text { alumínio. }\end{array}$ & Empírica & & PRIVADO & $\begin{array}{l}\text { Indústria do } \\
\text { alumínio }\end{array}$ & $\begin{array}{l}\text { Albrás } \\
\text { Alunorte }\end{array}$ & Barcarena & PA & $\begin{array}{l}\text { Condições de } \\
\text { trabalho; } \\
\text { Subjetividade } \\
\text { no trabalho; } \\
\text { Remuneração }\end{array}$ \\
\hline 3 & 1 & Capes & $\begin{array}{l}\text { Trabalhadores } \\
\text { terceirizados }\end{array}$ & $\begin{array}{l}\text { Estabelecer a relação } \\
\text { entre a reforma do } \\
\text { Estado, suas leis e } \\
\text { discursos, e a experiência } \\
\text { concreta dos } \\
\text { trabalhadores } \\
\text { terceirizados. }\end{array}$ & Empírica & & 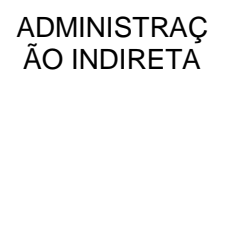 & Educação & USP & São Paulo & $\mathrm{SP}$ & $\begin{array}{l}\text { Condições de } \\
\text { trabalho; } \\
\text { Subjetividade } \\
\text { no trabalho; } \\
\text { Remuneração; } \\
\text { Saúde e } \\
\text { Seguranca }\end{array}$ \\
\hline 4 & 1 & Tese & $\begin{array}{l}\text { Trabalhadores } \\
\text { terceirizados }\end{array}$ & $\begin{array}{c}\text { Investigar as } \\
\text { competências de } \\
\text { trabalhadores terceiros a } \\
\text { partir de uma abordagem } \\
\text { ergológica. }\end{array}$ & Empírica & Ergologia & PRIVADO & $\begin{array}{l}\text { Informação e } \\
\text { comunicação }\end{array}$ & Telemar & $\begin{array}{l}\text { RM Belo } \\
\text { Horizonte }\end{array}$ & MG & $\begin{array}{l}\text { Condições de } \\
\text { trabalho; } \\
\text { Relações de } \\
\text { trabalho; } \\
\text { formação e } \\
\text { qualificação }\end{array}$ \\
\hline 5 & 1 & Tese & $\begin{array}{c}\text { Trabalhadores } \\
\text { terceirizados }\end{array}$ & $\begin{array}{l}\text { Analisar a precarização } \\
\text { das condições do trabalho } \\
\text { na construção civil a partir } \\
\text { do processo produtivo e } \\
\text { da avaliação dos } \\
\text { programas de }\end{array}$ & Empírica & & PRIVADO & Construção civil & ND & Campinas & SP & $\begin{array}{l}\text { Condições de } \\
\text { trabalho; } \\
\text { Emprego; } \\
\text { Formação e } \\
\text { qualificação }\end{array}$ \\
\hline
\end{tabular}

NSA - Não se aplica (por exemplo, quando se trata de serviços). ND - Não disponível (revisar na análise do texto completo). 
ANEXO III - Lista de teses e dissertação completas que não foram encontradas para Revisão Bibliográfica Sistemática (RBS)

\begin{tabular}{|c|c|c|c|c|c|c|c|}
\hline № & NOME & TÍTULO & $\begin{array}{l}\text { DADA DE } \\
\text { DEFESA }\end{array}$ & TITULAÇÃO & UNIVERSIDADE & UF & Resumo SALVO \\
\hline 6 & $\begin{array}{l}\text { Caires, Ângela } \\
\text { Cristina Ribeiro }\end{array}$ & $\begin{array}{l}\text { Fios tecidos: a malha da terceirização no } \\
\text { setor têxtil em Araraquara }\end{array}$ & 01/08/1999 & Doutorado & $\begin{array}{l}\text { Universidade } \\
\text { Est.Paulista Júlio De } \\
\text { Mesquita Filho }\end{array}$ & $\mathrm{SP}$ & $\begin{array}{l}\text { Solicitação via empréstimo } \\
\text { entre bibliotecas; não houve } \\
\text { retorno }\end{array}$ \\
\hline 14 & $\begin{array}{l}\text { Ferreira, Maria } \\
\text { Cristina } \\
\text { Godinho Lopes }\end{array}$ & $\begin{array}{l}\text { As faces da terceirização do trabalho: um } \\
\text { estudo sobre as relações, processo, } \\
\text { organização e condições de trabalhos } \\
\text { terceirizados em limpeza e vigilância na } \\
\text { Universidade Federal de Lavras }\end{array}$ & $29 / 05 / 2015$ & Doutorado & $\begin{array}{l}\text { Universidade Federal } \\
\text { De Juiz De Fora }\end{array}$ & $M G$ & $\begin{array}{l}\text { Não obtive retorno da } \\
\text { biblioteca. }\end{array}$ \\
\hline 16 & $\begin{array}{l}\text { Godinho, Luiz } \\
\text { Flavio Reis }\end{array}$ & $\begin{array}{l}\text { Laços frágeis e identidades fragmentadas: } \\
\text { discriminações entre trabalhadores da RLAM } \\
\text { - BA } 1990-2006 \text {. }\end{array}$ & $01 / 04 / 2008$ & Doutorado & $\begin{array}{l}\text { Universidade Federal } \\
\text { Da Paraíba/João } \\
\text { Pessoa }\end{array}$ & PB & $\begin{array}{l}\text { Não obtive retorno da } \\
\text { biblioteca. }\end{array}$ \\
\hline 21 & $\begin{array}{l}\text { Manãs, Antonio } \\
\text { Vico }\end{array}$ & Terceiros, parceiros, nós mesmos & 01/05/1999 & Doutorado & $\begin{array}{l}\text { Pontifícia } \\
\text { Universidade Católica } \\
\text { De São Paulo }\end{array}$ & $\mathrm{SP}$ & $\begin{array}{l}\text { Não há autorização para } \\
\text { digitalização. }\end{array}$ \\
\hline 25 & $\begin{array}{l}\text { Oliveira, Fabio } \\
\text { De }\end{array}$ & $\begin{array}{l}\text { Relações de trabalho e sentidos do } \\
\text { cooperativismo }\end{array}$ & $01 / 12 / 2005$ & Doutorado & $\begin{array}{l}\text { Pontifícia } \\
\text { Universidade Católica } \\
\text { De São Paulo }\end{array}$ & $\mathrm{SP}$ & $\begin{array}{l}\text { Não há autorização para } \\
\text { digitalização. }\end{array}$ \\
\hline 53 & $\begin{array}{l}\text { Alves, Edvaldo } \\
\text { Carvalho }\end{array}$ & $\begin{array}{l}\text { Trabalho precário e terceirização: as } \\
\text { cooperativas de produção no Nordeste }\end{array}$ & $01 / 02 / 2002$ & Mestrado & $\begin{array}{l}\text { Universidade Federal } \\
\text { De São Carlos }\end{array}$ & $\mathrm{SP}$ & $\begin{array}{l}\text { Solicitação via comut; não } \\
\text { obtive retorno. }\end{array}$ \\
\hline 61 & $\begin{array}{l}\text { Assunção, Any } \\
\text { Ávila }\end{array}$ & $\begin{array}{l}\text { Violência nos espaços de trabalho } \\
\text { terceirizados: exclusões, segregações e } \\
\text { discriminações }\end{array}$ & $01 / 03 / 2005$ & Mestrado & $\begin{array}{l}\text { Universidade De } \\
\text { Brasília }\end{array}$ & DF & $\begin{array}{l}\text { A biblioteca não pode } \\
\text { digitalizar sem autorização } \\
\text { da autora. Solicitei via } \\
\text { facebook mas não obtive } \\
\text { retorno. }\end{array}$ \\
\hline 85 & $\begin{array}{l}\text { Conceição, } \\
\text { Márcio Magera }\end{array}$ & $\begin{array}{l}\text { O novo complexo da reestruturação produtiva } \\
\text { no Brasil: o processo de terceirização e suas } \\
\text { implicações sociais }\end{array}$ & 01/03/2001 & Mestrado & $\begin{array}{l}\text { Pontifícia } \\
\text { Universidade Católica } \\
\text { De São Paulo }\end{array}$ & $\mathrm{SP}$ & $\begin{array}{l}\text { Não há autorização para } \\
\text { digitalização. }\end{array}$ \\
\hline 90 & $\begin{array}{l}\text { Dias, Ana } \\
\text { Patrícia }\end{array}$ & $\begin{array}{l}\text { A terceirização no segmento bancário: o caso } \\
\text { da caixa econômica de Natal/RN }\end{array}$ & $01 / 03 / 2002$ & Mestrado & $\begin{array}{l}\text { Universidade Federal } \\
\text { Do Rio Grande Do } \\
\text { Norte }\end{array}$ & $\mathrm{RN}$ & $\begin{array}{l}\text { Biblioteca disse que não } \\
\text { possui versão eletrônica; } \\
\text { não tem como digitalizar; e } \\
\text { não fazem parte do sistema } \\
\text { comut }\end{array}$ \\
\hline 97 & $\begin{array}{l}\text { Faria, Fábio } \\
\text { André De }\end{array}$ & $\begin{array}{l}\text { Sapateiros despolitizados: o caso das } \\
\text { cooperativas de fornecimento de mão de obra }\end{array}$ & $01 / 04 / 2002$ & Mestrado & $\begin{array}{l}\text { Universidade Federal } \\
\text { Do Rio Grande Do }\end{array}$ & $\mathrm{RN}$ & $\begin{array}{l}\text { Biblioteca disse que não } \\
\text { possui versão eletrônica; }\end{array}$ \\
\hline
\end{tabular}




\begin{tabular}{|c|c|c|c|c|c|c|c|}
\hline № & NOME & TíTULO & $\begin{array}{l}\text { DADA DE } \\
\text { DEFESA }\end{array}$ & TITULAÇÃO & UNIVERSIDADE & UF & Resumo SALVO \\
\hline & & de Itapipoca/CE & & & Norte & & $\begin{array}{l}\text { não tem como digitalizar; e } \\
\text { não fazem parte do sistema } \\
\text { comut }\end{array}$ \\
\hline 98 & $\begin{array}{l}\text { Ferreira, Daísa } \\
\text { Cristina }\end{array}$ & $\begin{array}{l}\text { Terceirização: uma nova ordem no mundo do } \\
\text { trabalho? }\end{array}$ & 01/03/2002 & Mestrado & $\begin{array}{l}\text { Universidade } \\
\text { Est.Paulista Júlio De } \\
\text { Mesquita Filho }\end{array}$ & SP & $\begin{array}{l}\text { Solicitação via empréstimo } \\
\text { entre bibliotecas; não houve } \\
\text { retorno }\end{array}$ \\
\hline 103 & $\begin{array}{l}\text { Godinho, Luis } \\
\text { Flávio Reis }\end{array}$ & $\begin{array}{l}\text { Um mosaico de classe: a terceirização na } \\
\text { refinaria Landulfo Alves }\end{array}$ & 01/06/2003 & Mestrado & $\begin{array}{l}\text { Universidade Federal } \\
\text { Da Bahia }\end{array}$ & BA & $\begin{array}{l}\text { Não obtive retorno da } \\
\text { biblioteca. }\end{array}$ \\
\hline 108 & $\begin{array}{l}\text { Lage, Flávia } \\
\text { De Aguiar }\end{array}$ & $\begin{array}{l}\text { A nova cidade Indústrial: reestruturação } \\
\text { produtiva em Contagem (MG) e impactos no } \\
\text { setor terciário local (1990-2003) }\end{array}$ & 01/03/2005 & Mestrado & $\begin{array}{l}\text { Pontifícia } \\
\text { Universidade Católica } \\
\text { De Minas Gerais }\end{array}$ & MG & $\begin{array}{l}\text { Não obtive retorno da } \\
\text { biblioteca. }\end{array}$ \\
\hline 109 & $\begin{array}{l}\text { Landini, Sonia } \\
\text { Regina }\end{array}$ & $\begin{array}{l}\text { Terceirização das condições de trabalho e } \\
\text { alguns aspectos educativos - uma estudo de } \\
\text { caso }\end{array}$ & 01/02/1997 & Mestrado & $\begin{array}{l}\text { Pontifícia } \\
\text { Universidade Católica } \\
\text { De São Paulo }\end{array}$ & SP & $\begin{array}{l}\text { Não há autorização para } \\
\text { digitalização. }\end{array}$ \\
\hline 113 & $\begin{array}{l}\text { Lopes, Rodolfo } \\
\text { Antônio }\end{array}$ & $\begin{array}{l}\text { Reestruturação produtiva em Contagem - } \\
\text { MG: precarização do trabalho e da proteção } \\
\text { social }\end{array}$ & $01 / 12 / 2011$ & Mestrado & $\begin{array}{l}\text { Pontifícia } \\
\text { Universidade Católica } \\
\text { De Minas Gerais }\end{array}$ & MG & $\begin{array}{l}\text { Não obtive retorno da } \\
\text { biblioteca. }\end{array}$ \\
\hline 124 & $\begin{array}{l}\text { Moreira, } \\
\text { Sandra Helena } \\
\text { Lima }\end{array}$ & $\begin{array}{l}\text { O mundo invisível das micro-unidades } \\
\text { produtivas no setor de CONFEC - COES - as } \\
\text { Facções }\end{array}$ & 01/03/1996 & Mestrado & $\begin{array}{l}\text { Universidade Federal } \\
\text { Do Ceará }\end{array}$ & CE & $\begin{array}{l}\text { A bilioteca afirmou que iria } \\
\text { digitalizar e enviar em } 20 \\
\text { dias, mas isso não ocorreu. }\end{array}$ \\
\hline 126 & $\begin{array}{l}\text { Oliveira, } \\
\text { Antonio Carlos } \\
\text { Silva De }\end{array}$ & $\begin{array}{l}\text { Subjetividade e as condições de trabalho dos } \\
\text { vigilantes bancários }\end{array}$ & $31 / 03 / 2014$ & Mestrado & $\begin{array}{l}\text { Universidade Cândido } \\
\text { Mendes }\end{array}$ & RJ & $\begin{array}{l}\text { Não obtive retorno da } \\
\text { biblioteca. }\end{array}$ \\
\hline 135 & $\begin{array}{l}\text { Pereira, Carla } \\
\text { Regina } \\
\text { Assunção }\end{array}$ & $\begin{array}{l}\text { Estratégias de terceirização, usos singulares: } \\
\text { empresas e trabalhadores no consórcio } \\
\text { modular da Volkswagen de Resende (RJ) }\end{array}$ & 01/07/2002 & Mestrado & $\begin{array}{l}\text { Universidade Federal } \\
\text { Do Rio De Janeiro }\end{array}$ & RJ & $\begin{array}{l}\text { Não obtive retorno da } \\
\text { biblioteca. }\end{array}$ \\
\hline 145 & $\begin{array}{l}\text { Rosa, Rosane } \\
\text { Candelária Da } \\
\text { Silva }\end{array}$ & $\begin{array}{l}\text { O novo perfil do profissional de } \\
\text { telecomunicações: perspectivas frente às } \\
\text { mudanças nas relações sociais do trabalho }\end{array}$ & 01/03/2005 & Mestrado & $\begin{array}{l}\text { Universidade Federal } \\
\text { Fluminense }\end{array}$ & RJ & $\begin{array}{l}\text { Biblioteca ficou de avaliar a } \\
\text { possibilidade de digitalizar, } \\
\text { mas não retornou. }\end{array}$ \\
\hline 152 & $\begin{array}{l}\text { Santo, } \\
\text { WecisleyRibeir } \\
\text { o Do Espírito }\end{array}$ & $\begin{array}{l}\text { Trabalho, gênero e lingerie: tradição e } \\
\text { transformação nas trajetórias das costureiras } \\
\text { de roupas íntimas de Nova Friburgo-RJ }\end{array}$ & 01/02/2009 & Mestrado & $\begin{array}{l}\text { Universidade Federal } \\
\text { Do Rio De Janeiro }\end{array}$ & RJ & $\begin{array}{l}\text { Biblioteca pegou fogo e a } \\
\text { dissertação foi destruída. }\end{array}$ \\
\hline 156 & $\begin{array}{l}\text { Santos, Ester } \\
\text { Vianna Dos }\end{array}$ & $\begin{array}{l}\text { Terceirização e a representação sindical: um } \\
\text { estudo sobre as condições de trabalho no } \\
\text { setor elétrico do estado do Espírito Santo }\end{array}$ & $31 / 08 / 2016$ & Mestrado & $\begin{array}{l}\text { Política Universidade } \\
\text { Vila Velha }\end{array}$ & ES & $\begin{array}{l}\text { Não obtive retorno da } \\
\text { biblioteca. }\end{array}$ \\
\hline
\end{tabular}




\begin{tabular}{|c|c|c|c|c|c|c|c|}
\hline № & NOME & TÍTULO & $\begin{array}{l}\text { DADA DE } \\
\text { DEFESA }\end{array}$ & TITULAÇÃO & UNIVERSIDADE & UF & Resumo SALVO \\
\hline 157 & $\begin{array}{l}\text { Santos, José } \\
\text { Carlos dos }\end{array}$ & $\begin{array}{l}\text { A terceirização em questão: um olhar sobre a } \\
\text { experiência da precarização do trabalho nas } \\
\text { instituições públicas em Juazeiro do Norte }\end{array}$ & 01/07/2002 & Mestrado & $\begin{array}{l}\text { Universidade Federal } \\
\text { Do Ceará }\end{array}$ & CE & $\begin{array}{l}\text { Não está disponível na } \\
\text { Biblioteca nem mesmo a } \\
\text { cópia física. }\end{array}$ \\
\hline 165 & $\begin{array}{l}\text { Souza, Elaine } \\
\text { Silva de }\end{array}$ & $\begin{array}{l}\text { A "a maquiagem" do trabalho formal: um } \\
\text { estudo do trabalho das mulheres terceirizadas } \\
\text { no setor de limpeza na universidade federal } \\
\text { da Bahia }\end{array}$ & $01 / 12 / 2012$ & Mestrado & $\begin{array}{l}\text { Universidade Federal } \\
\text { Da Bahia }\end{array}$ & $\mathrm{BA}$ & $\begin{array}{l}\text { Não obtive retorno da } \\
\text { biblioteca. }\end{array}$ \\
\hline
\end{tabular}


ANEXO IV - Teses e dissertações completas que foram excluídas da RBS, após leitura sistemática

\begin{tabular}{|c|c|c|c|c|c|c|c|c|}
\hline № & NOME & TÍTULO & $\begin{array}{l}\text { DADA DE } \\
\text { DEFESA }\end{array}$ & TITULAÇÃO & AREA & UNIVERSIDADE & UF & MOTIVO DE EXCLUSÃO \\
\hline 10 & $\begin{array}{l}\text { Cordeiro, } \\
\text { Rosemary De } \\
\text { Matos }\end{array}$ & $\begin{array}{l}\text { As aglomerações produtivas de } \\
\text { calçados, folheados e de jóias } \\
\text { do Crajubar (CE): formação, } \\
\text { produção, trabalho, implicações } \\
\text { socioespaciais }\end{array}$ & 06/05/2015 & Doutorado & Geografia & $\begin{array}{l}\text { Universidade Est. } \\
\text { Paulista Júlio De } \\
\text { Mesquita Filho }\end{array}$ & SP & $\begin{array}{l}\text { Trabalho à domicílio como } \\
\text { terceirização; fora do escopo conceitual } \\
\text { da pesquisa. }\end{array}$ \\
\hline 17 & $\begin{array}{l}\text { Jacques, } \\
\text { Caroline Da } \\
\text { Graca }\end{array}$ & $\begin{array}{l}\text { Trabalho decente e } \\
\text { responsabilidade social } \\
\text { empresarial nas cadeias } \\
\text { produtivas globais: o modelo } \\
\text { fast fashion em Portugal e no } \\
\text { Brasil }\end{array}$ & $27 / 03 / 2015$ & Doutorado & $\begin{array}{l}\text { Sociologia } \\
\text { política }\end{array}$ & $\begin{array}{l}\text { Universidade } \\
\text { Federal De Santa } \\
\text { Catarina }\end{array}$ & SC & $\begin{array}{l}\text { Não é sobre condições e relações de } \\
\text { trabalho dos terceirizados; é pesquisa } \\
\text { documental que enfoca o trabalho } \\
\text { decente e a SER. }\end{array}$ \\
\hline 30 & $\begin{array}{l}\text { Pereira, } \\
\text { Rosângela } \\
\text { Maria }\end{array}$ & $\begin{array}{l}\text { De trabalhadoras precárias a } \\
\text { empreendedoras da confecção? } \\
\text { A complexa construção da } \\
\text { identidade profissional das } \\
\text { trabalhadoras a domicílio da } \\
\text { indústria de confecção }\end{array}$ & $01 / 03 / 2011$ & Doutorado & Sociologia & $\begin{array}{l}\text { Universidade } \\
\text { Federal Do Rio } \\
\text { Grande Do Sul }\end{array}$ & $\mathrm{RS}$ & $\begin{array}{l}\text { Os dados sobre terceirizadas somam } \\
\text { as informações de trabalhadoras a } \\
\text { domicílio que contratam outras } \\
\text { trabalhadoras e de empresas que } \\
\text { contratam trabalhadoras a domicilio } \\
\text { fora do escopo conceitual da pesquisa. }\end{array}$ \\
\hline 33 & Raulino, Ivo & $\begin{array}{l}\text { Crise e reestruturação produtiva } \\
\text { na grande empresa têxtil do } \\
\text { médio vale do Itajaí }\end{array}$ & $01 / 04 / 2008$ & Doutorado & $\begin{array}{l}\text { Geografia } \\
\text { (Geografia } \\
\text { humana) }\end{array}$ & $\begin{array}{l}\text { Universidade De } \\
\text { São Paulo }\end{array}$ & SP & $\begin{array}{l}\text { Analisa a reestruturação produtiva com } \\
\text { foco na reorganização das empresas; a } \\
\text { reorganização do trabalho entra como } \\
\text { um elemento da reestruturação das } \\
\text { empresas, mas não há análise dos } \\
\text { efeitos para as condições de trabalho } \\
\text { dos terceirizados, especificamente. }\end{array}$ \\
\hline 35 & $\begin{array}{l}\text { Siebert, } \\
\text { Cláudia } \\
\text { Araripe } \\
\text { Freitas }\end{array}$ & $\begin{array}{l}\text { Indústria e estado: a } \\
\text { reestruturação produtiva e o } \\
\text { reordenamento territorial do } \\
\text { médio Vale do Itajaí }\end{array}$ & $01 / 09 / 2006$ & Doutorado & Geografia & $\begin{array}{l}\text { Universidade } \\
\text { Federal De Santa } \\
\text { Catarina }\end{array}$ & SC & $\begin{array}{l}\text { Analisa a reestruturação produtiva com } \\
\text { foco na reorganização das empresas; a } \\
\text { reorganização do trabalho entra como } \\
\text { um elemento da reestruturação das } \\
\text { empresas, mas não há análise dos } \\
\text { efeitos para as condições de trabalho } \\
\text { dos terceirizados, especificamente. }\end{array}$ \\
\hline 39 & $\begin{array}{l}\text { Souza, Plinio } \\
\text { João De }\end{array}$ & $\begin{array}{l}\text { Profissionais da informática: } \\
\text { outros fluxos do trabalho dos } \\
\text { programadores }\end{array}$ & $01 / 11 / 2011$ & Doutorado & $\begin{array}{l}\text { Ciências } \\
\text { Sociais }\end{array}$ & $\begin{array}{c}\text { Pontifícia } \\
\text { Universidade } \\
\text { Católica De São }\end{array}$ & SP & $\begin{array}{l}\text { Tem apenas um dado sobre doenças } \\
\text { de trabalho, mas não há informações } \\
\text { se os entrevistados são terceirizados }\end{array}$ \\
\hline
\end{tabular}




\begin{tabular}{|c|c|c|c|c|c|c|c|c|}
\hline & & & & & & Paulo & & ou não; \\
\hline 49 & $\begin{array}{l}\text { Zanatta, } \\
\text { Mariana } \\
\text { Scussel }\end{array}$ & $\begin{array}{l}\text { Quando o fabrico se torna } \\
\text { fábrica: desdobramentos do } \\
\text { processo de formalização dos } \\
\text { empreendimentos Industriais de } \\
\text { confecções em Caruaru/PE }\end{array}$ & $28 / 03 / 2016$ & Doutorado & Sociologia & $\begin{array}{l}\text { Universidade } \\
\text { Federal Do Rio } \\
\text { Grande Do Sul }\end{array}$ & RS & $\begin{array}{l}\text { Analisa o processo produtivo, com foco } \\
\text { na precariedade dos trabalhadores que } \\
\text { se tornaram microempreendedores, } \\
\text { que fabricam os vestuários para as } \\
\text { empresas maiores. Apesar de serem } \\
\text { ex-trabalhadores explorados, nesse } \\
\text { contexto, eles são os empregadores } \\
\text { dos trabalhadores terceirizados. }\end{array}$ \\
\hline 50 & $\begin{array}{l}\text { Zientarski, } \\
\text { Clarice }\end{array}$ & $\begin{array}{l}\text { Para onde vai a voz que ainda } \\
\text { ecoa em nós? A dialética } \\
\text { alienação/transformação no } \\
\text { trabalho dos professores }\end{array}$ & $26 / 04 / 2013$ & Doutorado & Educação & $\begin{array}{l}\text { Universidade } \\
\text { Federal De Santa } \\
\text { Maria }\end{array}$ & RS & $\begin{array}{l}\text { Trabalhadores autônomos (consultores } \\
\text { governo federal): pelo nosso conceito, } \\
\text { não são trabalhadores terceirizados. }\end{array}$ \\
\hline 55 & $\begin{array}{l}\text { Andrade, } \\
\text { José } \\
\text { Cristovão De }\end{array}$ & $\begin{array}{l}\text { Reestruturação produtiva e } \\
\text { condições de trabalho - um } \\
\text { estudo dos trabalhadores da } \\
\text { indústria de fiação e tecelagem } \\
\text { de algodão de Campina Grande } \\
\text { - Paraíba }\end{array}$ & $01 / 03 / 2001$ & Mestrado & Sociologia & $\begin{array}{l}\text { Universidade } \\
\text { Federal Da } \\
\text { Paraíba/João } \\
\text { Pessoa }\end{array}$ & PB & $\begin{array}{l}\text { Estuda a reestruturação produtiva em } \\
\text { três empresas do setor têxtil, mas não } \\
\text { apresenta uma análise sobre o } \\
\text { processo de terceirização nessas } \\
\text { empresas, apesar de mencionar que } \\
\text { esse é um dos elementos da } \\
\text { reestruturação produtiva. Talvez, a } \\
\text { terceirizaçâo seja um processo no polo } \\
\text { industrial local, mas não nas } 3 \\
\text { empresas estudadas. }\end{array}$ \\
\hline 58 & $\begin{array}{l}\text { Araujo, Paula } \\
\text { Hypolito De }\end{array}$ & $\begin{array}{l}\text { Os (des)caminhos da estrada: a } \\
\text { organização do trabalho dos } \\
\text { caminhoneiros no porto de } \\
\text { Santos }\end{array}$ & $01 / 04 / 2010$ & Mestrado & $\begin{array}{l}\text { Ciências } \\
\text { Sociais }\end{array}$ & $\begin{array}{l}\text { Universidade Est. } \\
\text { Paulista Júlio De } \\
\text { Mesquita Filho }\end{array}$ & $\mathrm{SP}$ & $\begin{array}{l}\text { Motorista autônomos; fora do escopo } \\
\text { conceitual da pesquisa. }\end{array}$ \\
\hline 62 & $\begin{array}{l}\text { Balcão, Nilde } \\
\text { Ferreira }\end{array}$ & $\begin{array}{l}\text { Terceirização e desmontagem } \\
\text { do contrato de trabalho }\end{array}$ & 01/09/2000 & Mestrado & Sociologia & USP & SP & $\begin{array}{l}\text { Não tem dados de trabalho de campo } \\
\text { sobre condições de trabalho. }\end{array}$ \\
\hline 66 & $\begin{array}{l}\text { Batista, } \\
\text { Eraldo Leme }\end{array}$ & $\begin{array}{l}\text { Terceirização no Brasil e suas } \\
\text { implicações para os } \\
\text { trabalhadores }\end{array}$ & 01/02/2006 & Mestrado & Educação & $\begin{array}{l}\text { Universidade } \\
\text { Estadual De } \\
\text { Campinas }\end{array}$ & $\mathrm{SP}$ & $\begin{array}{l}\text { Não tem dados de trabalho de campo } \\
\text { sobre condições de trabalho. }\end{array}$ \\
\hline 68 & $\begin{array}{l}\text { Bergamin, } \\
\text { Paula Dias } \\
\text { Vasconcelos }\end{array}$ & $\begin{array}{l}\text { Cooperativismo e precarização } \\
\text { do trabalho na região nordeste }\end{array}$ & $01 / 02 / 2004$ & Mestrado & Educação & $\begin{array}{l}\text { Universidade } \\
\text { Estadual De } \\
\text { Campinas }\end{array}$ & SP & $\begin{array}{l}\text { Não tem dados de trabalho de campo } \\
\text { sobre condições de trabalho. }\end{array}$ \\
\hline 84 & $\begin{array}{l}\text { Coli, Juliana } \\
\text { Marília }\end{array}$ & $\begin{array}{l}\text { O façonismo pelo avesso: um } \\
\text { estudo das novas formas de }\end{array}$ & $01 / 08 / 1997$ & Mestrado & Sociologia & $\begin{array}{l}\text { Universidade } \\
\text { Estadual De }\end{array}$ & $\mathrm{SP}$ & $\begin{array}{l}\text { Estuda o novo façonista, ou seja, o } \\
\text { trabalhador que saiu da grande }\end{array}$ \\
\hline
\end{tabular}




\begin{tabular}{|c|c|c|c|c|c|c|c|c|}
\hline & & $\begin{array}{l}\text { organização do trabalho à } \\
\text { fração no ramo de tecelagem } \\
\text { do pólo têxtil de Americana - SP }\end{array}$ & & & & Campinas & & $\begin{array}{l}\text { empresa e montou seu próprio negocio, } \\
\text { contratando outros trabalhadores ou } \\
\text { através de um negocio familiar. }\end{array}$ \\
\hline 95 & $\begin{array}{l}\text { Dziekaniak, } \\
\text { Fabio } \\
\text { Alexandre }\end{array}$ & $\begin{array}{l}\text { Os sentidos do trabalho na } \\
\text { tutoria a distância: buscando } \\
\text { compreensões à luz da } \\
\text { educação ambiental }\end{array}$ & 10/04/2014 & Mestrado & $\begin{array}{l}\text { Educação } \\
\text { ambiental }\end{array}$ & $\begin{array}{l}\text { Universidade } \\
\text { Federal Do Rio } \\
\text { Grande }\end{array}$ & RS & $\begin{array}{l}\text { Contratação temporária pela própria } \\
\text { instituição de ensino. }\end{array}$ \\
\hline 102 & $\begin{array}{l}\text { Ghisleni, } \\
\text { Angela Peña }\end{array}$ & $\begin{array}{l}\text { Corpos ressentidos: trabalho } \\
\text { contemporâneo, subjetividade e } \\
\text { patologias por hipersolicitação }\end{array}$ & $01 / 01 / 2003$ & Mestrado & $\begin{array}{l}\text { Psicologia } \\
\text { Social e } \\
\text { Institucional }\end{array}$ & $\begin{array}{l}\text { Universidade } \\
\text { Federal Do Rio } \\
\text { Grande Do Sul }\end{array}$ & RS & $\begin{array}{l}\text { Trata da saúde, de um modo geral, } \\
\text { sem recorte para terceirizados. }\end{array}$ \\
\hline 105 & $\begin{array}{l}\text { Jorge, Heber } \\
\text { Rebouças }\end{array}$ & $\begin{array}{l}\text { Terceirizar, flexibilizar, } \\
\text { precarizar: um estudo crítico } \\
\text { sobre a terceirização do } \\
\text { trabalho }\end{array}$ & $01 / 03 / 2011$ & Mestrado & Sociologia & $\begin{array}{l}\text { Universidade } \\
\text { Estadual De } \\
\text { Campinas }\end{array}$ & SP & $\begin{array}{l}\text { Pesquisa teórica, não tem dados } \\
\text { primários sobre as condições e } \\
\text { relações de trabalho. }\end{array}$ \\
\hline 112 & $\begin{array}{l}\text { Lopes, Luis } \\
\text { Augusto }\end{array}$ & $\begin{array}{l}\text { A qualificação profissional nas } \\
\text { tramas da terceirização: o setor } \\
\text { petrolífero, a Petrobrás e o } \\
\text { PROMINP }\end{array}$ & $01 / 12 / 2012$ & Mestrado & $\begin{array}{l}\text { Ciências } \\
\text { Sociais }\end{array}$ & $\begin{array}{l}\text { Universidade } \\
\text { Federal Da Bahia }\end{array}$ & BA & $\begin{array}{l}\text { Trata de programa de qualificação } \\
\text { profissional, gerenciado pela Petrobras, } \\
\text { para as empresas terceiras, mas não } \\
\text { têm dados e informações sobre as } \\
\text { condições e relações de trabalho dos } \\
\text { terceirizados. }\end{array}$ \\
\hline 121 & $\begin{array}{l}\text { Mello, } \\
\text { Isabella } \\
\text { Jinkings }\end{array}$ & $\begin{array}{l}\text { Reestruturação produtiva e } \\
\text { emprego na indústria têxtil } \\
\text { catarinense }\end{array}$ & $01 / 12 / 2002$ & Mestrado & Sociologia & $\begin{array}{c}\text { Política } \\
\text { Universidade } \\
\text { Federal De Santa } \\
\text { Catarina }\end{array}$ & SC & $\begin{array}{l}\text { Considera a terceirização dentro das } \\
\text { mudanças produtivas, mas sem análise } \\
\text { sobre impacto para condições de } \\
\text { trabalho com dados primários. }\end{array}$ \\
\hline 131 & Partocki, Eva & $\begin{array}{l}\text { Professores substitutos: } \\
\text { neoliberalismo e a flexibilização } \\
\text { do trabalho docente }\end{array}$ & $01 / 04 / 2012$ & Mestrado & Educação & $\begin{array}{l}\text { Universidade Tuiuti } \\
\text { Do Paraná }\end{array}$ & PR & $\begin{array}{l}\text { Apesar de a pesquisadora ter como } \\
\text { objetivo a realização de pesquisa } \\
\text { empírica, no decorrer do processo, e } \\
\text { devido a falta de disponibilidade das } \\
\text { empresas definidas como alvo de } \\
\text { fornecer informações, ou ainda, de } \\
\text { conseguir entrevistar professores, a } \\
\text { pesquisa acabou por focar na pesquisa } \\
\text { bibliográfica. }\end{array}$ \\
\hline 168 & $\begin{array}{l}\text { Souza, } \\
\text { Rodinele } \\
\text { Ribeiro De }\end{array}$ & $\begin{array}{l}\text { A identidade de classe dos } \\
\text { petroleiros da bacia de campos }\end{array}$ & $01 / 12 / 2012$ & Mestrado & Sociologia & $\begin{array}{c}\text { Política } \\
\text { Universidade } \\
\text { Estadual Do Norte } \\
\text { Fluminense Darcy }\end{array}$ & RJ & $\begin{array}{l}\text { A pesquisa acabou sendo realizada } \\
\text { apenas com os trabalhadores diretos } \\
\text { da Petrobras, parte de seu olhar para } \\
\text { uma avaliação do trabalho terceirizado, }\end{array}$ \\
\hline
\end{tabular}




\begin{tabular}{|c|c|c|c|c|c|c|c|c|}
\hline & & & & & & Ribeiro & & $\begin{array}{l}\text { o que julgamos não fazer parte de } \\
\text { nosso escopo. }\end{array}$ \\
\hline 170 & $\begin{array}{l}\text { Souza, } \\
\text { Tatiele } \\
\text { Pereira De }\end{array}$ & $\begin{array}{l}\text { Identidade e subalternidade: a } \\
\text { construção da identidade de } \\
\text { trabalhadores serventes de } \\
\text { limpeza }\end{array}$ & $01 / 07 / 2011$ & Mestrado & Sociologia & $\begin{array}{l}\text { Universidade } \\
\text { Federal De Goiás }\end{array}$ & GO & $\begin{array}{l}\text { Compara as relações de trabalho entre } \\
\text { homens e mulheres, terceirizados e } \\
\text { não terceirizados. O recorte } \\
\text { fundamental dos dados primários é o } \\
\text { trabalho feminino; os dados não são } \\
\text { separados entre terceirizados e não } \\
\text { terceirizados. }\end{array}$ \\
\hline 150 & $\begin{array}{l}\text { Santana, } \\
\text { Alex Tristão } \\
\text { De }\end{array}$ & $\begin{array}{l}\text { A territorialização da indústria } \\
\text { automobilística em Catalão e as } \\
\text { mudanças no trabalho }\end{array}$ & $01 / 06 / 2011$ & Mestrado & Geografia & $\begin{array}{l}\text { Universidade } \\
\text { Federal De Goiás }\end{array}$ & $\mathrm{GO}$ & $\begin{array}{l}\text { Não tem dados de trabalho de campo } \\
\text { sobre condições de trabalho. }\end{array}$ \\
\hline
\end{tabular}

